University of Nebraska - Lincoln

DigitalCommons@University of Nebraska - Lincoln

2006

\title{
Geochemical Data for Mercury, Methylmercury, and Other Constituents in Sediments from Englebright Lake, California, 2002
}

Charles N. Alpers

U.S. Geological Survey

Michael P. Hunerlach

U.S. Geological Survey

Mark C. Marvin-DiPasquale

U.S. Geological Survey, mmarvin@usgs.gov

Ronald C. Antweiler

U.S. Geological Survey

Brenda K. Lasorsa

Battelle Marine Sciences Laboratory

See next page for additional authors

Follow this and additional works at: https://digitalcommons.unl.edu/usgspubs

Part of the Earth Sciences Commons

Alpers, Charles N.; Hunerlach, Michael P.; Marvin-DiPasquale, Mark C.; Antweiler, Ronald C.; Lasorsa, Brenda K.; De Wild, John F.; and Snyder, Noah P., "Geochemical Data for Mercury, Methylmercury, and Other Constituents in Sediments from Englebright Lake, California, 2002" (2006). Publications of the US Geological Survey. 62.

https://digitalcommons.unl.edu/usgspubs/62

This Article is brought to you for free and open access by the US Geological Survey at DigitalCommons@University of Nebraska - Lincoln. It has been accepted for inclusion in Publications of the US Geological Survey by an authorized administrator of DigitalCommons@University of Nebraska - Lincoln. 


\section{Authors}

Charles N. Alpers, Michael P. Hunerlach, Mark C. Marvin-DiPasquale, Ronald C. Antweiler, Brenda K. Lasorsa, John F. De Wild, and Noah P. Snyder 
CALFED Ecosystem Restoration Program, California Bay-Delta Authority, and California Resources Agency

\section{Geochemical Data for Mercury, Methylmercury, and Other Constituents in Sediments from Englebright Lake, California, 2002}

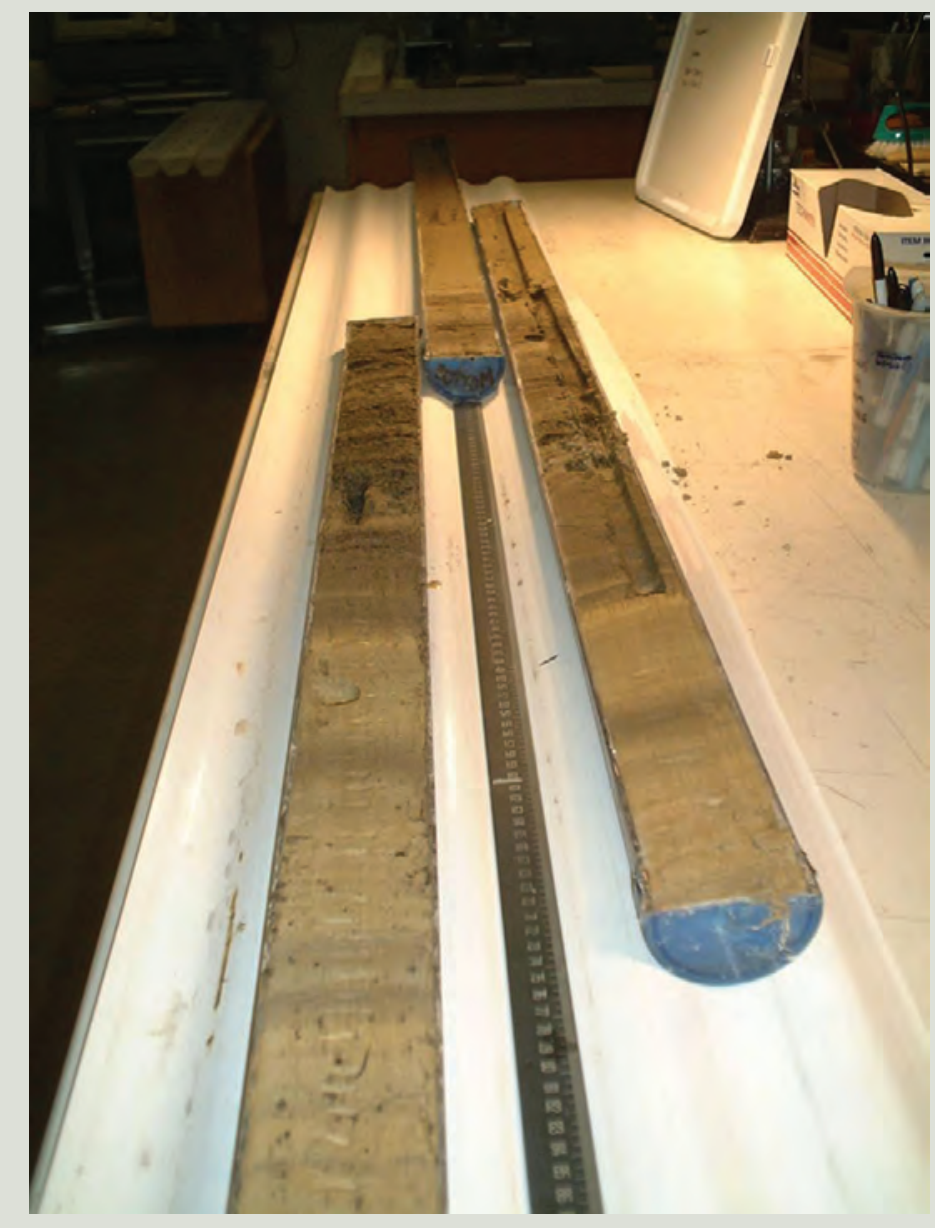

Data Series 151

U.S. Department of the Interior U.S. Geological Survey 
Photograph on front cover: Three cores from Englebright Lake, site 8, showing correlation of stratigraphy, November 11, 2002. Photograph by Noah P. Snyder. 


\section{Geochemical Data for Mercury, Methylmercury, and Other Constituents in Sediments from Englebright Lake, California, 2002}

By Charles N. Alpers' ${ }^{1}$ Michael P. Hunerlach'1, Mark C. Marvin-DiPasquale²,

Ronald C. Antweiler ${ }^{3}$, Brenda K. Lasorsa ${ }^{4}$, John F. De Wild ${ }^{5}$, and Noah P. Snyder ${ }^{6}$

Prepared in cooperation with the

CALFED Ecosystem Restoration Program, the California Bay-Delta Authority, and the

California Resources Agency

Data Series 151

'U.S. Geological Survey, 6000 J Street, Placer Hall, Sacramento, CA 95819-6129.

2U.S. Geological Survey, 345 Middlefield Road, Mailstop 480, Menlo Park, CA 94025.

3U.S. Geological Survey, 3215 Marine Street, Suite E-127, Boulder, CO 80303.

${ }^{4}$ Battelle Marine Sciences Laboratory, 1529 West Sequim Bay Road, Sequim, WA 98382.

5U.S. Geological Survey, 8505 Research Way, Middleton, WI 53562.

${ }^{6}$ Dept. of Geology and Geophysics, Boston College, 140 Commonwealth Avenue, Chestnut Hill, MA 02467.

U.S. Department of the Interior

U.S. Geological Survey 


\section{U.S. Department of the Interior \\ Dirk Kempthorne, Secretary \\ U.S. Geological Survey \\ Mark D. Myers, Director}

\section{U.S. Geological Survey, Reston, Virginia: 2006}

For product and ordering information:

World Wide Web: http://www.usgs.gov/pubprod

Telephone: 1-888-ASK-USGS

For more information on the USGS--the Federal source for science about the Earth, its natural and living resources, natural hazards, and the environment:

World Wide Web: http://www.usgs.gov

Telephone: 1-888-ASK-USGS

Any use of trade, product, or firm names is for descriptive purposes only and does not imply endorsement by the U.S. Government.

Although this report is in the public domain, permission must be secured from the individual copyright owners to reproduce any copyrighted materials contained within this report.

Suggested reference:

Alpers, C.N., Hunerlach, M.P., Marvin-DiPasquale, M.C., Antweiler, R.C., Lasorsa, B.K., De Wild, J.F., and Snyder, N.P., 2006, Geochemical data for mercury, methylmercury, and other constituents in sediments from Englebright Lake, California, 2002: U.S. Geological Survey Data Series 151, 95 p. 


\section{Contents}

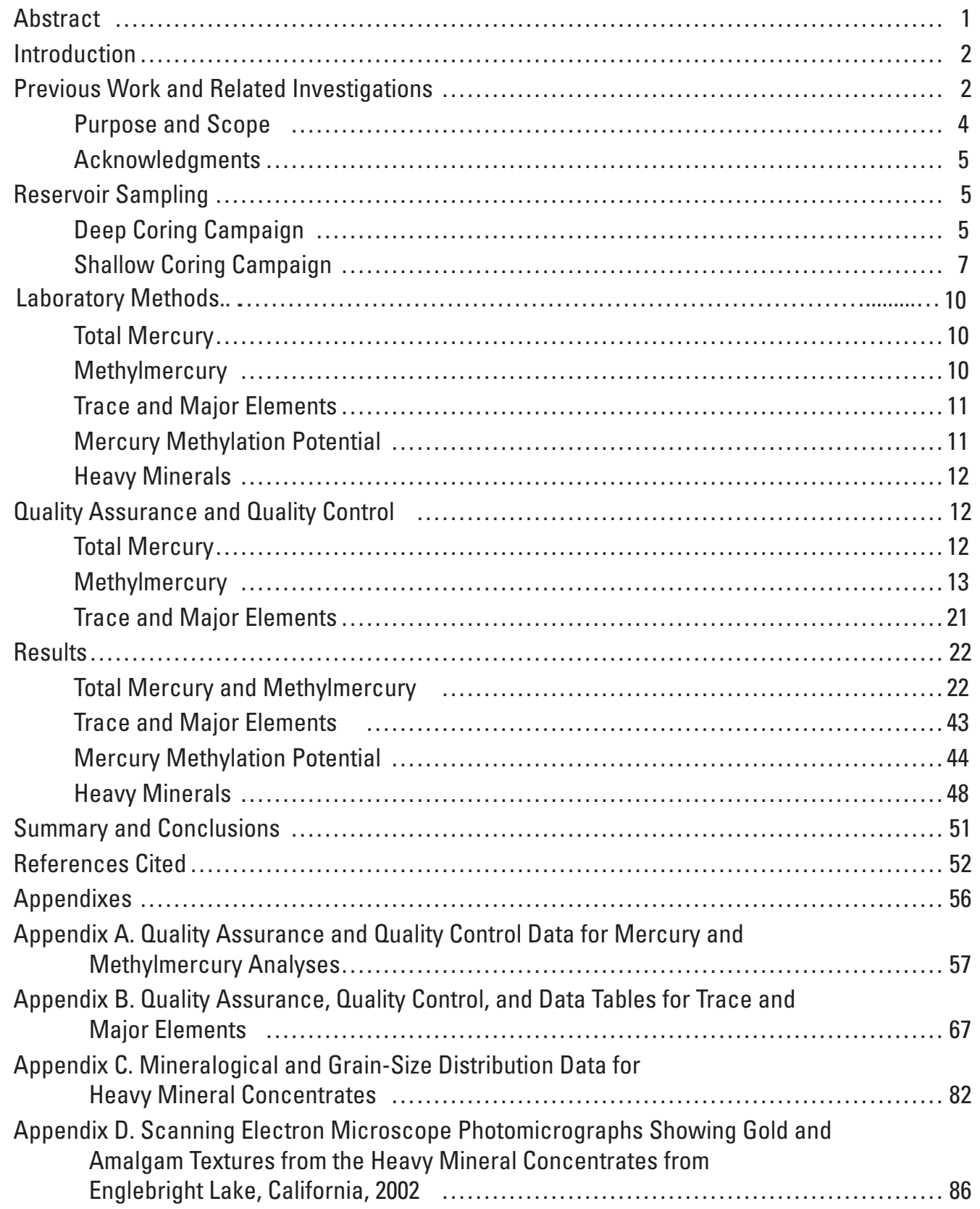




\section{Figures}

Figure 1. Map showing location of Englebright Lake in the Yuba River watershed, California

Figure 2. Map showing locations of deep and shallow coring, Englebright Lake, California

Figure 3. Detailed maps of sampling locations at Englebright Lake, California 9

Figure 4. Deep coring profiles showing concentrations of trace metals and median grain size in sieved sediment subsamples (Y-series) from site 1 at Englebright Lake, California, May-June, 2002

Figure 5. Deep coring profiles showing concentrations of trace metals and median grain size in unsieved sediment subsamples ( $\mathrm{Y}$-series) from site 4 at Englebright Lake, California, May-June, 2002

Figure 6. Deep coring profiles showing concentrations of trace metals and median grain size in sieved sediment subsamples ( $\mathrm{Y}$-series) from site 7 at Englebright Lake, California, May-June, 2002

Figure 7. Deep coring profiles showing concentrations of trace metals and median grain size in sieved sediment subsamples (Y-series) from site 9 at Englebright Lake, California, May-June, 2002

Figure 8. Deep coring profiles showing concentrations of trace metals and median grain size in sieved sediment subsamples (Y-series) from site 8 at Englebright Lake, California, May-June, 2002

Figure 9. Plots showing relations with depth for unsieved sediment subsamples (shallow cores and selected deep cores) at Englebright Lake, California, May-June, 2002: (A) Total mercury, $(\boldsymbol{B})$ Methylmercury, $(\boldsymbol{C})$ Ratio of methylmercury to total mercury, and $(\boldsymbol{D})$ Median grain size

Figure 10.Plots showing ${ }^{203} \mathrm{Hg}(\mathrm{II})$-methylation potential rate as a function of depth for sediments from Englebright Lake, California, 2002: (A) Sites 1 and 11,

(B) Sites 4 and 10, (C) Sites 9 and 12.

Figure 11.Plots showing correlation of the ${ }^{203} \mathrm{Hg}(\mathrm{II})$-methylation potential rate for shallow sediments from Englebright Lake, California, 2002: (A) Redox potential, (B) pH .... 48

Figure 12.Plots showing correlation of the ratio of methylmercury to total mercury with forms of iron and carbon in shallow sediments from Englebright Lake,

California, 2002 .

Figure 13.Photograph showing gold and amalgam grains from heavy-mineral concentrate 5 A from Englebright Lake, California 50

Figure 14.Longitudinal section showing gold tenor in composite core intervals from Englebright Lake, California, 2002

Appendix A. Quality Assurance and Quality Control Data for Mercury and Methylmercury Analyses:

Figure A1. Graph showing results of analysis by two laboratories of total mercury in split subsamples from Englebright Lake, California, 2002.

Figure A2. Graph showing results of analysis by two laboratories of methylmercury in split subsamples from Englebright Lake, California, 2002. 
Appendix D. Scanning Electron Microscope Photomicrographs Showing Gold and Amalgam Textures from the Heavy Mineral Concentrates from Englebright Lake, California, 2002:

Figure D1. Amalgam grain showing abrasion from processing (sample 5A) 86

Figure D2. Two scanned electron microscope images of pseudo-hexagonal hematite platelets surrounded by mercury-rich halo, $(\boldsymbol{A})$ Backscatter,

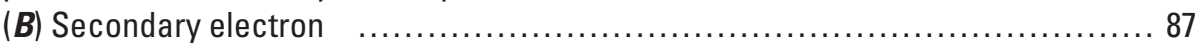

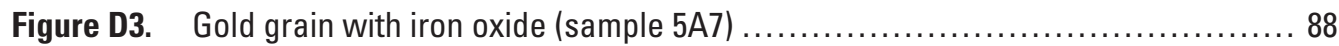

Figure D4. Gold grain with abundant diagenetic pyrite crystals (sample 5AC1) ............ 88

Figure D5. Iron-oxide coated gold nugget and clean gold nugget (sample 5AC2) . ......... 89

Figure D6. High magnification of pitted surface of gold nugget (sample 7B1) . ............. 89

Figure D7. Extensive cracking of amalgam in mercury-saturated gold nugget

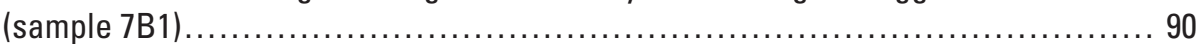

Figure D8. Close-up view of nugget showing abrasion of amalgam in cavity with

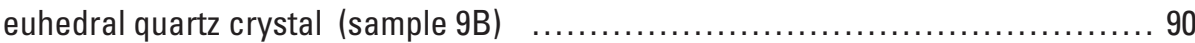

Figure D9 . Amalgam grains (sample 9B) (A) Aggregate containing amalgam crystal in upper right, and $(\boldsymbol{B})$ Close-up view of the amalgam crystal .................... 91

Figure D10. Placer gold grain of high purity, no visible mercury (sample 9B8)

(A) View of entire grain, $(\boldsymbol{B})$ Close-up view showing smooth texture of gold $\ldots \ldots \ldots 92$

Figure D11. Large, pitted gold grain with 100-micrometer, euhedral zircon

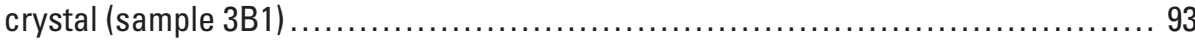

Figure D12. Grain of gold containing small beads of elemental mercury (sample 3B3) ........ 93

Figure D13. Grain of amalgam showing smearing from processing (sample 3B4) ............ 94

Figure D14. Grain of amalgam showing fracture (sample 3B5) ........................ 94

Figure D15. Octahedral crystal forms of gold in vug of nugget (sample 8A1) ............. 95

Figure D16. Iron-stained gold nugget with no trace of mercury (sample 2B1) . .............. 95

\section{Tables}

Table 1. Basic data for sediment sample series from Englebright Lake, California, $2002 \ldots \ldots 6$

Table 2. Mercury data from the $Y$ series of subsamples from deep cores, Englebright Lake,

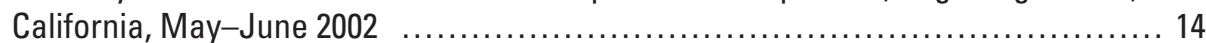

Table 3. Mercury and methylmercury data from the MEM series of subsamples from deep cores, Englebright Lake, California, May-June 2002

Table 4. Mercury and methylmercury data for shallow cores taken at Englebright Lake, California, October 2002

Table 5. Statistical data showing longitudinal variation in mercury and methylmercury concentrations in sediments collected during 2002 from Englebright Lake, California

Table 6. Statistical data showing vertical variation in the mercury and methylmercury concentrations of sediments collected during 2002 from Englebright Lake, California

Table 7. Statistical data showing longitudinal variation in concentrations of select trace metals in sediments collected during 2002 from Englebright Lake, California .....

Table 8. Whole-sediment ${ }^{203} \mathrm{Hg}(\mathrm{II})$-methylation rate constants and calculated potential rates for shallow and deep sediments (MP series) from Englebright Lake, California, 2002 
Table 9. Chemical data for the MP series of sediment samples from Englebright Lake, California, 2002 . 47

Table 10. Chemical data for pore water from the MP series of sediment samples from Englebright Lake, California, 2002. 50

Table A1. Total mercury concentrations in standard reference materials. 58

Table A2. Total mercury data for replicate sediment subsamples from Englebright Lake, California, 2002

Table A3. Methylmercury concentrations in standard reference materials. 62

Table A4. Methylmercury data for replicate sediment subsamples from Englebright Lake, California, 2002 65

Table A5. Comparison of results from two laboratories for total mercury and methylmercury in split sediment subsamples from Englebright Lake, California, 2002 66

Table B1. Concentrations of trace metals and major elements in standard reference materials

Table B2. Data for trace metals and major elements in digestion blanks 76

Table B3. Recovery data for trace-metal spikes in sediment samples from Englebright Lake, California, 2002

Table B4. Data for trace metals and major elements in replicate sediment subsamples from Englebright Lake, California, 2002

Table B5. Data for trace metals and major elements from the $Y$ series of subsamples from the May-June 2002 deep cores from Englebright Lake, California 81

Table C1. Particle-size distribution of bulk composite core samples prior to preparation of heavy mineral concentrates, Englebright Lake, California, 2002

Table C2. Particle-size distribution and gold tenor of heavy mineral concentrates, Englebright Lake, California, 2002

Table C3. Mineralogical data from magnetic separation and optical microscopy for heavy mineral concentrates, Englebright Lake, California, 2002

Table C4. Summary of textural observations by scanning electron microscope on gold and amalgam in heavy mineral concentrates, Englebright Lake, California, 2002 


\section{Conversion Factors, Datums Used, and Abbreviations}

Conversion Factors-SI to Inch/Pound

\begin{tabular}{|c|c|c|}
\hline Multiply & By & To obtain \\
\hline \multicolumn{3}{|c|}{ Length } \\
\hline centimeter $(\mathrm{cm})$ & 0.3937 & inch (in.) \\
\hline kilometer $(\mathrm{km})$ & 0.6214 & mile (mi) \\
\hline millimeter $(\mathrm{mm})$ & 0.03937 & inch (in.) \\
\hline meter $(\mathrm{m})$ & 3.281 & foot $(\mathrm{ft})$ \\
\hline meter $(\mathrm{m})$ & 1.094 & yard (yd) \\
\hline nanometer $(\mathrm{nm})$ & $3.0937 \times 10^{-8}$ & inch (in.) \\
\hline \multicolumn{3}{|c|}{ Area } \\
\hline square kilometer $\left(\mathrm{km}^{2}\right)$ & 247.1 & acre \\
\hline square centimeter $\left(\mathrm{cm}^{2}\right)$ & 0.001076 & square foot $\left(\mathrm{ft}^{2}\right)$ \\
\hline square meter $\left(\mathrm{m}^{2}\right)$ & 10.76 & square foot $\left(\mathrm{ft}^{2}\right)$ \\
\hline hectare (ha) & 0.003861 & square mile $\left(\mathrm{mi}^{2}\right)$ \\
\hline square kilometer $\left(\mathrm{km}^{2}\right)$ & 0.3861 & square mile $\left(\mathrm{mi}^{2}\right)$ \\
\hline \multicolumn{3}{|c|}{ Volume } \\
\hline cubic meter $\left(\mathrm{m}^{3}\right)$ & 264.2 & gallon (gal) \\
\hline cubic centimeter $\left(\mathrm{cm}^{3}\right)$ & 0.06102 & cubic inch $\left(\mathrm{in}^{3}\right)$ \\
\hline cubic meter $\left(\mathrm{m}^{3}\right)$ & 35.31 & cubic foot $\left(\mathrm{ft}^{3}\right)$ \\
\hline cubic meter $\left(\mathrm{m}^{3}\right)$ & 1.308 & cubic yard $\left(\mathrm{yd}^{3}\right)$ \\
\hline cubic meter $\left(\mathrm{m}^{3}\right)$ & 0.0008107 & acre-foot (acre-ft) \\
\hline liter (L) & 61.02 & cubic inch $\left(\mathrm{in}^{3}\right)$ \\
\hline liter (L) & 0.2642 & gallon (gal) \\
\hline milliliter (mL) & 0.0610 & cubic inch $\left(\mathrm{in}^{3}\right)$ \\
\hline \multicolumn{3}{|c|}{ Mass and Mass Flux } \\
\hline $\operatorname{gram}(\mathrm{g})$ & 0.03527 & ounce, avoirdupois (oz) \\
\hline kilogram (kg) & 2.205 & pound, avoirdupois (lb) \\
\hline megagram $(\mathrm{Mg})$ & 1.102 & ton, short $(2,000 \mathrm{lb})$ \\
\hline megagram $(\mathrm{Mg})$ & 0.9842 & ton, long $(2,240 \mathrm{lb})$ \\
\hline metric ton per day (tonne/d) & 1.102 & ton, short, per day (ton/d) \\
\hline megagram per day $(\mathrm{Mg} / \mathrm{d})$ & 1.102 & ton, short, per day (ton/d) \\
\hline $\begin{array}{l}\text { megagram per day per square } \\
\text { kilometer }\left[(\mathrm{Mg} / \mathrm{d}) / \mathrm{km}^{2}\right]\end{array}$ & 2.8547 & $\begin{array}{l}\text { ton, short, per day per square mile } \\
{\left[(\text { ton } / \mathrm{d}) / \mathrm{mi}^{2}\right]}\end{array}$ \\
\hline megagram per year (Mg/yr) & 1.102 & ton, short, per year (ton/yr) \\
\hline metric ton per year (tonne/yr) & 1.102 & ton, short, per year (ton/yr) \\
\hline \multicolumn{3}{|c|}{ Radioactivity } \\
\hline becquerel per liter $(\mathrm{Bq} / \mathrm{L})$ & 27.027 & picocurie per liter $(\mathrm{pCi} / \mathrm{L})$ \\
\hline
\end{tabular}

\section{Datums Used}

Vertical coordinate information is referenced to the North American Vertical Datum of 1988 (NAVD 88).

Horizontal coordinate information is referenced to the North American Datum of 1983 (NAD 83).

Elevation, as used in this report, refers to distance above the vertical datum. 


\section{Acronyms, Abbreviations, and Chemical Notation}

\section{Acronyms}

ASL, above sea level

ASTM, American Society for Testing and Materials

BMSL, Battelle Marine Sciences Laboratory (Sequim, Washington)

CRV, certified reference value

CVAAS, cold vapor atomic-absorption spectrometry

CVAFS, cold vapor atomic-fluorescence spectrometry

$\mathrm{DI}$, deionized (water)

DOC, dissolved organic carbon

EDS, energy dispersive spectrometer

IAEA, International Atomic Energy Agency

ICP-AES, inductively coupled plasma-atomic emission spectrometry

ICP-MS, inductively coupled plasma-mass spectrometry

$M D$, methylmercury degradation

MDL, method detection limit

MEM series, MEthylMercury sample series

MP, methylmercury production (sample series)

NIST, National Institute of Standards and Technology

$\mathrm{QA}$, quality assurance

QC, quality control

$\mathrm{RPD}$, relative percentage difference

RSD, relative standard deviation

SEM, scanning electron microscope

SR, sulfate reduction

SRM, standard reference material

USEPA, United States Environmental Protection Agency

USGS, United States Geological Survey

UYRSP, Upper Yuba River Studies Program

WDML, Wisconsin District Mercury Laboratory (Middleton, Wisconsin)

\section{Abbreviations}

$\mathrm{cm}$, centimeter

$\mathrm{cm}^{3}$, cubic centimeter

g, gram

$\mathrm{kg}$, kilogram

$\mathrm{L}$, liter

$\mathrm{mCi} / \mathrm{mg}$, millicurie per milligram

mg, milligram

$\mathrm{mg} \mathrm{Au} / \mathrm{m}^{3}$, milligram of gold per cubic meter

$\mathrm{M} \Omega$-cm, megaohm-centimeter

$\mu \mathrm{Ci} / 100 \mu \mathrm{L}$, microcurie per 100 microliters

$\mu \mathrm{g}$, microgram

$\mu \mathrm{m}$, micrometer

ng, nanogram

ng/g, nanogram per gram

$\mathrm{ng} \mathrm{Hg} / \mathrm{g}$ dry sediment/d, nanograms of mercury per gram dry sediment per day

ppb, parts per billion 
ppm, parts per million

$R^{2}$, coefficient of determination for linear least-squares regression

rpm, revolutions per minute

$\mathrm{t} / \mathrm{km}^{2} / \mathrm{yr}$, tonnes per square kilometer per year

wt, weight

$>$, greater than

$<$, less than

$\sim$, approximately, about

\section{Chemical Elements}

Al, aluminum

As, arsenic

Au, gold

$B$, boron

$\mathrm{Ba}$, barium

Be, beryllium

$\mathrm{Bi}$, bismuth

Ca, calcium

Cd, cadmium

Ce, cerium

$\mathrm{Cl}$, chloride

Co, cobalt

$\mathrm{Cr}$, chromium

Cs, cesium

Cu, copper

Dy, dysprosium

Er, erbium

Eu, europium

$\mathrm{Fe}$, iron

Gd, gadolinium

Ho, holmium

$\mathrm{Hg}$, mercury

In, indium

Ir, iridium

$\mathrm{K}$, potassium

La, lanthanum

Li, lithium

Lu, lutetium

Mg, magnesium

$\mathrm{Mn}$, manganese

Mo, molybdenum

$\mathrm{N}$, nitrogen

$\mathrm{Na}$, sodium

$\mathrm{Nd}$, neodymium

$\mathrm{Ni}$, nickel

P, phosphorus

$\mathrm{Pb}$, lead

Pr, praseodymium

$\mathrm{Rb}$, rubidium

Re, rhenium 


\title{
Chemical Compounds, Isotopes, and Other Chemical Notation
}

\author{
$\mathrm{CH}_{3}{ }^{203} \mathrm{Hg}^{+}$, methylmercury ion with radiolabeled mercury \\ $\mathrm{CH}_{4}$, methane \\ $\mathrm{CH}_{2} \mathrm{Cl}_{2}$, methylene chloride \\ $\mathrm{CuSO}_{4}$, copper sulfate \\ $\mathrm{Fe}(\mathrm{II})$, ferrous (divalent) iron \\ $\mathrm{Fe}(\mathrm{III})$, ferric (trivalent) iron \\ $\mathrm{HCl}$, hydrochloric acid \\ $\mathrm{HF}$, hydrofluoric acid \\ $\mathrm{HNO}_{3}$, nitric acid \\ $\mathrm{Hg}^{0}$, elemental mercury \\ $\mathrm{Hg}^{+}$, mercurous ion \\ $\mathrm{Hg}^{2+}$, mercuric ion \\ $\mathrm{Hg}(\mathrm{II})$, divalent mercury \\ $\mathrm{HgCl}_{2}$, mercuric chloride \\ $\mathrm{Hg}_{\mathrm{T}}$, total mercury \\ ${ }^{203} \mathrm{Hg}(\mathrm{II})$, mercury-203 radiotracer divalent inorganic mercury \\ $\mathrm{KBr}$, potassium bromide \\ $\mathrm{MeHg}$, methylmercury (monomethylmercury) \\ $\mathrm{N}_{2}$, nitrogen gas \\ $\mathrm{NaBEt}_{4}$, sodium tetra-ethyl borate \\ $\mathrm{O}_{2}$, oxygen gas \\ $\mathrm{SiO}_{2}$, silicon dioxide, or silica \\ $\mathrm{SnCl}_{2}$, stannous chloride
}




\title{
Geochemical Data for Mercury, Methylmercury, and Other Constituents in Sediments from Englebright Lake, California, 2002
}

\author{
By Charles N. Alpers, Michael P. Hunerlach, Mark C. Marvin-DiPasquale, Ronald C. Antweiler, \\ Brenda K. Lasorsa, John F. De Wild, and Noah P. Snyder
}

\section{Abstract}

This report presents geochemical data from two 2002 sampling campaigns conducted in Englebright Lake on the Yuba River in northern California. A deep coring campaign was done in May-June 2002 and a shallow sampling campaign was completed in October 2002. This work assessed the chemical composition of material deposited in the reservoir between 1940, the year Englebright Dam was completed, and 2002 as part of the Upper Yuba River Studies Program, an effort designed to evaluate the feasibility of introducing anadromous fish, including steelhead and spring-run Chinook salmon, upstream from Englebright Dam. Results of analyses of total mercury $\left(\mathrm{Hg}_{\mathrm{T}}\right)$ in 444 subsamples, methylmercury $(\mathrm{MeHg})$ in 243 subsamples, and other trace and major elements in 202 subsamples are presented. Data quality was evaluated on the basis of analyses of replicate pairs of subsamples, standard reference materials, blanks, and spike additions.

Deep coring penetrated the full thickness of material deposited after 1940 at six locations in the reservoir; the cores reached a maximum depth of 32.8 meters below the reservoir floor. At the three deep coring sites closest to Englebright Dam, concentrations of $\mathrm{Hg}_{\mathrm{T}}$ (dry basis) were consistently in the range of 100 to $500 \mathrm{ng} / \mathrm{g}$ (nanogram per gram), in sediment dominantly of silt size (median grain size of 0.004 to $0.063 \mathrm{~mm}$ [millimeter]). At the deep coring sites located farther upstream, the upper parts of the profile had lower concentrations of $\mathrm{Hg}_{\mathrm{T}}$, generally ranging from 2 to $100 \mathrm{ng} / \mathrm{g}$, in sediment dominantly of sand size (median grain size from 0.063 to $2 \mathrm{~mm}$ ). The lower part of the vertical profiles at three upstream coring sites had higher concentrations of $\mathrm{Hg}_{\mathrm{T}}$ than the upper and middle parts of these profiles, and had finer median grain size.

The highest median concentration of $\mathrm{MeHg}(1.1 \mathrm{ng} / \mathrm{g})$ was in the top $2 \mathrm{~cm}$ (centimeter) of the shallow box cores. This vertical interval also had the highest value of the ratio of $\mathrm{MeHg}$ to $\mathrm{Hg}_{\mathrm{T}}, 0.41$ percent. Median concentrations of $\mathrm{MeHg}$ and median values of $\mathrm{MeHg} / \mathrm{Hg}_{\mathrm{T}}$ decreased systematically with depth from $0-4$ to $4-8$ to $8-12 \mathrm{~cm}$ in the shallow cores.
However, similar systematic decreases were not observed at the meter scale in the deep cores of the MEM (MEthylMercury) series. The overall median of the ratio $\mathrm{MeHg} / \mathrm{Hg}_{\mathrm{T}}$ in the deep cores was 0.25 percent, not much less than the overall median value for the shallow cores ( 0.33 percent).

Mercury-203 radiotracer divalent inorganic mercury $\left({ }^{203} \mathrm{Hg}(\mathrm{II})\right)$ was used to determine microbial mercury-methylation potential rates for 11 samples collected from three reservoir locations and various depths in the sediment profile. For the five shallow mercury-methylation subsamples, ancillary geochemical parameters were assayed, including microbial sulfate reduction rates, sulfur speciation (sediment acid volatile sulfide, total reduced sulfur, and pore-water sulfate), iron speciation (sediment acid extractable iron(II), amorphous iron(III), crystalline iron(III) and pore-water iron(II)), porewater chloride and dissolved organic carbon, and $\mathrm{pH}$, oxidation-reduction potential (Eh) and whole-sediment organic content. The highest potential rates of microbial mercury methylation were measured in shallow (0 to $8 \mathrm{~cm}$ depth) sediments (5 to 30 nanograms of mercury per gram dry sediment per day), whereas potential rates for subsamples collected from depths greater than $500 \mathrm{~cm}$ were consistently below the detection limit of the radiotracer method ( $<0.02$ nanogram of mercury per gram dry sediment per day).

Chemical analyses of trace and major elements in bed sediment are presented for 202 samples from deep cores from five locations in Englebright Lake. The mean values and standard deviations for selected trace elements were as follows (in micrograms per gram): antimony, $2.4 \pm 1.6$; arsenic, $69 \pm 48$; chromium, $134 \pm 23$; lead, $33 \pm 25$; and nickel, $87 \pm 24$.

Concentrated samples of heavy-mineral grains, prepared using nine large-volume composite samples from deep cores, were examined using optical and scanning-electron microscopy. Estimated gold concentrations in the composite sediment samples ranged from 38 to 840 milligrams per cubic meter. Grains of gold-mercury amalgam and grains of electrum (native gold), with and without mercury staining, were observed in the heavy-mineral concentrates. 
Results of this study will be used to evaluate potential effects on fish habitat and trace-element transport in relation to various scenarios regarding efforts to improve fish passage at Englebright Lake. The scenarios include dredging or release of sediments to downstream environments in association with dam modification or removal.

\section{Introduction}

Harry L. Englebright Lake (Englebright Lake; fig. 1) is a 14-kilometer-long reservoir located on the Yuba River in the Sierra Nevada foothills of northern California. The reservoir is impounded by Englebright Dam, which is $80 \mathrm{~m}$ (meter) tall and was completed in December 1940 by the California Debris Commission. Its primary purpose was to help mitigate flood risk in the Central Valley around Marysville by impounding sediment from anticipated future hydraulic-mining activity in the watershed upstream. At present, the reservoir is a popular destination for recreational boaters and campers and is a site for hydroelectric power generation. The reservoir also serves as an afterbay for peak power generation at the New Colgate Powerhouse, which receives water from New Bullards Bar Reservoir on the North Yuba River (fig. 1).

The Upper Yuba River Studies Program (UYRSP), sponsored by the California Bay-Delta Authority (formerly the California-Federal Bay-Delta Program, or CALFED), is evaluating the feasibility of introducing anadromous fish species to the Yuba River system upstream from Englebright Dam (fig. 1). The scope of the UYRSP has six elements: sediment (quality and quantity), water quality, habitat, flood risk, water supply and hydropower, and socio-economics; the U.S. Geological Survey (USGS) is responsible for the technical aspects of the sediment and water-quality elements of the program. To achieve the UYRSP objective of fish passage at Englebright Dam, management scenarios under consideration include lowering or removing the dam. Any reduction in size of the dam would result in some change in the sediment regime of the lower Yuba River and could cause the release of sediment stored in Englebright Lake. This increased sediment load could exacerbate existing physical and chemical hazards in the lower Yuba River area. Sediment deposition could raise riverbed elevations and therefore increase flood risk in the valley around Marysville (fig. 1). Because much of the stored material is likely derived from historical gold mining areas in the Yuba River watershed (James, 2005), it may contain high concentrations of mercury $(\mathrm{Hg})$ and other heavy metals that were lost during gold mining and recovery operations (Alpers and Hunerlach, 2000; Ashley, 2002; Alpers and others, 2005a, 2005b).

The release of Hg-rich sediment from Englebright Lake could increase the amount of $\mathrm{Hg}$ available for bioaccumulation in downstream areas. The ability to predict accurately the fate and transport of the material stored in Englebright Lake is critical to assessing the feasibility of various dam-management scenarios. This report presents data from two 2002 sedimentsampling campaigns undertaken by the USGS to characterize the three-dimensional distribution of mercury, methylmercury, and other constituents in sediments trapped in Englebright Lake, and the current potential for active methylmercury production in vertical sediment profiles.

\section{Previous Work and Related Investigations}

A previous report as part of the UYRSP describing reservoir bathymetry and pre-dam Yuba River topography (Childs and others, 2003) concluded that, in 2001, Englebright Lake contained 21,890,000 $\mathrm{m}^{3}$ (cubic meter) of material deposited since the completion of Englebright Dam, reducing the original storage capacity $\left(85,970,000 \mathrm{~m}^{3}\right)$ by 25.5 percent. Details of a deep coring campaign conducted in May-June 2002 by the USGS were documented by Snyder and others (2004a), who also presented data on the moisture content and bulk density of reservoir bed sediment. Results of grain-size distribution and loss-on-ignition (a proxy for organic content) analyses for subsamples from the deep coring campaign and a shallow coring campaign conducted in October 2002 were provided by Snyder and others (2004b). Using the data for grain-size distribution, density, and loss on ignition derived from the deep cores and shallow subsamples, Snyder and others (2004c) quantified the mass, organic content, and grainsize distribution of Englebright Lake sediments. Two distinct extrapolation methods yielded nearly identical estimates of the mass of the reservoir deposit: $26 \times 10^{6}$ metric tons, of which 64.7-68.5 percent is sand (0.063-2 $\mathrm{mm}$ [millimeter]) and gravel (coarser than $2 \mathrm{~mm}$ ).

The sedimentation rate for Englebright Lake is high compared with that for many other lakes and reservoirs. A prograding delta near the middle of the lake has accumulated sediment up to $32.8 \mathrm{~m}$ (meter) thick over the 61-year history of the reservoir, or an average of more than $0.5 \mathrm{~m} / \mathrm{yr}$ (meter per year). Near Englebright Dam, where the grain-size distribution is dominated by silt, the overall accumulation during 1941-2002 was about $6 \mathrm{~m}$, for an average accumulation rate of about $0.1 \mathrm{~m} / \mathrm{yr}$. In comparison, much lower sedimentation rates, ranging from 0.004 to $0.066 \mathrm{~m} / \mathrm{yr}$, were reported by Van Metre and others (2001) for 3 lakes and 8 reservoirs located throughout the United States. Sedimentation rates in Englebright Lake are also higher than those in each of 56 U.S. lakes and reservoirs cored by the USGS during 1992-2001 (Van Metre and others 2004). Snyder and others (2004c) computed a maximum basin-wide sediment yield of 340 metric $\mathrm{t} / \mathrm{km}^{2} / \mathrm{yr}$ (tonne per square kilometer per year) over the 61-year history of Englebright Lake, assuming no contribution from upstream parts of the watershed impounded by other dams such as Spaulding Dam and Milton Dam (fig. 1). A conceptual model for erosion and sedimentation in the upper Yuba River watershed was presented by Curtis and others (2005). Less than 5 percent of Englebright Lake sedimentation can be accounted for by mass wasting on hill slopes in 

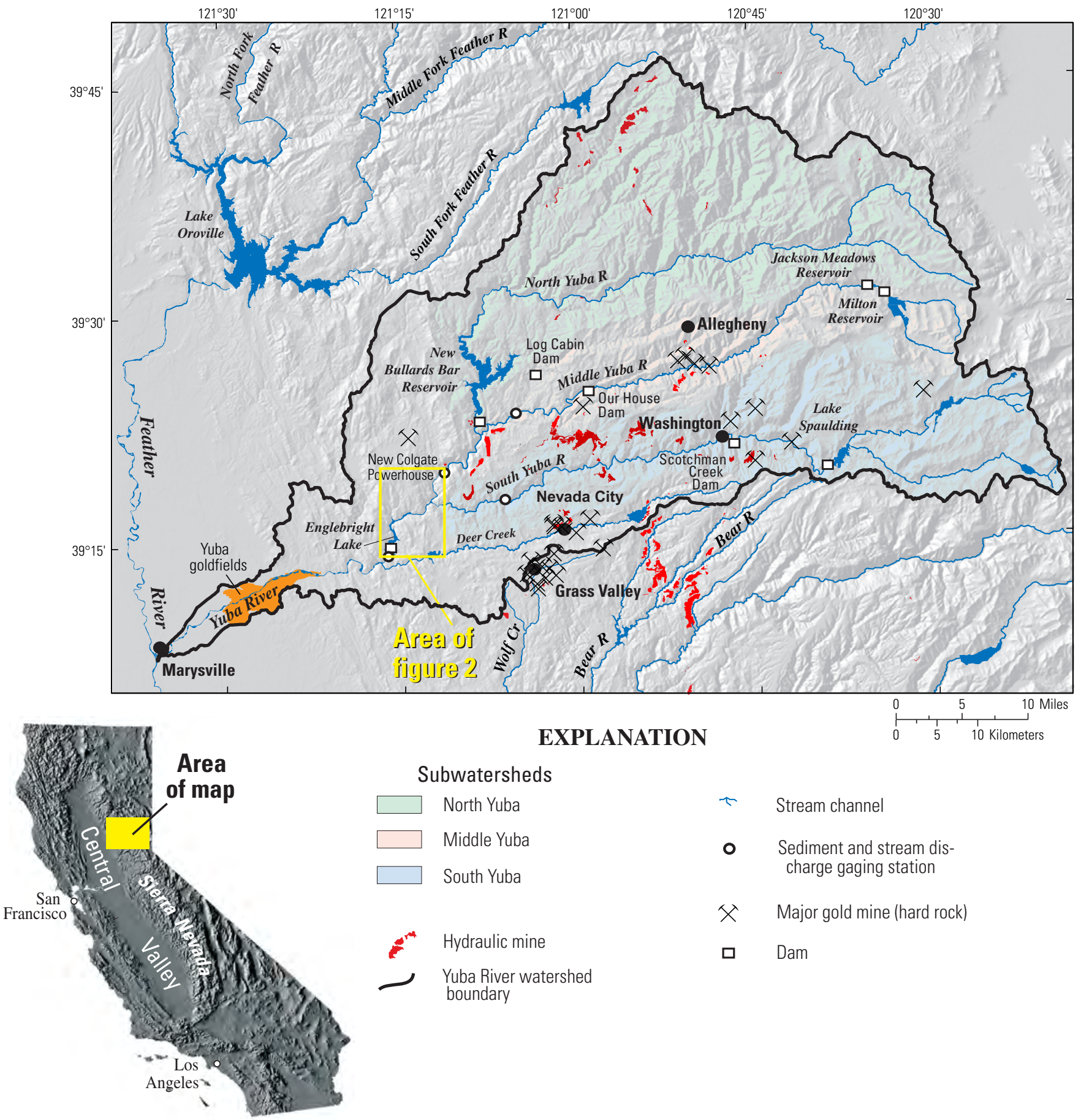

\section{Subwatersheds \\ North Yuba \\ Middle Yuba \\ South Yuba}

Hydraulic mine Yuba River watershed

Figure 1. Location of Englebright Lake in the Yuba River watershed, California.

the Middle Yuba River and South Yuba River, two of the three main tributaries to Englebright Lake. In the third main tributary, the North Yuba River, transport of coarse sediment has been blocked since the construction of New Bullards Bar Dam in 1970. Licensed hydraulic mining during 1893-1950 (James, 2005) can account for an additional 10 percent of Englebright
Lake sedimentation (Curtis and others, 2005). The remainder (more than 85 percent) is thought to be primarily from remobilization of sediment stored in active and semi-active channels; much of this stored sediment is from unregulated hydraulic mining of placer gold deposits in the watershed from the early 1850s through 1884 (Curtis and others, 2005). 
The effect on sediments of legacy contamination associated with historical hardrock gold mining is also an issue in the Yuba River watershed. Hardrock mining in the Mother Lode gold belt was concentrated in the vicinity of Grass Valley and Nevada City and also in the Alleghany District (Clark, 1963; Alpers and others, 2005b). Some of the largest hardrock mines in the Grass Valley and Nevada City areas do not drain into tributaries of Englebright Lake; the Grass Valley area drains primarily into Wolf Creek, a tributary of the Bear River (fig. 1), and the Nevada City area drains primarily into Deer Creek, a tributary to the Yuba River downstream of Englebright Dam (fig. 1). However, some of the hardrock mines near Nevada City, such as the Davis and Hoge mines on Little Rock Creek and the Ancho Erie mine on Poorman Creek, drain into the South Yuba River. The Alleghany mining district is located primarily within the Kanaka Creek subwatershed, which drains into the Middle Yuba River, a tributary to Englebright Lake (fig. 1). In general, mill tailings from hardrock gold mines of the Sierra Nevada may contain elevated concentrations of mercury that was added to enhance gold recovery by amalgamation at stamp mills (Churchill, 2000; Ashley, 2002). These tailings may also contain naturally occurring concentrations of trace elements such as arsenic, antimony, and lead (Ashley, 2002). Historical mining practices included depositing mill tailings directly into streams or capturing tailings in impoundments, some of which remain prone to failure during large storm events (Ashley, 2002).

The bioaccumulation of mercury in aquatic organisms, including invertebrates and fish, is most elevated in the portions of the northern Sierra Nevada that are affected by historical gold mining (Slotton and others, 1997, 2004; Alpers and Hunerlach, 2000; Alpers and others, 2004a, 2005b). Data for mercury bioaccumulation in sport fish from a reconnaissance sampling by the USGS of Englebright Lake and other water bodies in the Yuba River and Bear River watersheds were published by May and others (2000). These data led the State of California to issue an advisory that recommends limited consumption of smallmouth bass in Englebright Lake (Klasing and Brodberg, 2003). Results of additional studies of mercury bioaccumulation in fish and zooplankton from Englebright Lake and in fish and invertebrates from stream sites in South Yuba, Middle Yuba, and lower Yuba Rivers (Slotton and others, 2004) are part of the UYRSP Water Quality scope of work and will be published in separate reports. An additional component of the UYRSP Water Quality work involved USGS monitoring of mercury and methylmercury concentrations and other water-quality parameters in the main tributaries to Englebright Lake and the Yuba River below Englebright Dam (Alpers and others, 2004b) during 2001-04. Load calculations and mass balances of mercury and methylmercury with regard to Englebright Lake based on the water-quality monitoring will be published separately.

Downstream of Englebright Dam, the lower Yuba River is considered to be a critical habitat for endangered aquatic species, including steelhead trout (Oncorhynchus mykiss) and spring-run Chinook salmon (O. tshawytsha) (National Marine
Fisheries Service, 2005). A USGS investigation (Hunerlach and others, 2004) characterized the concentrations of mercury and methylmercury, mercury methylation potential, and the grain-size distribution of sediment trapped behind Daguerre Point Dam in the Yuba Goldfields area (fig. 1), which was affected by deposition of hydraulic mining debris and subsequent dredging of placer gold deposits. Resource management issues at Daguerre Point Dam are similar to those at Englebright Dam because removing or modifying either dam to improve anadromous fish passage may disturb the sediments contaminated with mercury from historical gold mining (California Department of Water Resources, 2003). Although concentrations of methylmercury in sediments trapped behind Daguerre Point Dam were low, moderately elevated concentrations of total mercury were found in fine-grained sediment fractions (Hunerlach and others, 2004). The environmental risk associated with release of fine-grained sediment containing an elevated concentration of mercury is related to the potential for the mercury to be converted to the more toxic form of methylmercury if conditions are favorable. Aquatic life is exposed to methylmercury through dietary pathways, leading to biomagnification in the food web and potential harm to higher-trophic-level organisms, including humans and piscivorous wildlife (Wiener and others, 2003).

\section{Purpose and Scope}

The purpose of this report is to present data collected by the USGS on the geochemistry of sediments in Englebright Lake and associated information regarding data quality and methods of sampling and analysis. Data for subsamples of deep cores taken during May-June 2002 and of shallow cores taken during October 2002 are presented. Results for total mercury $\left(\mathrm{Hg}_{\mathrm{T}}\right)$ analyses on 444 subsamples, methylmercury (MeHg) analyses on 243 subsamples, and analyses of other trace and major elements on 202 subsamples are presented. Methods used to collect, preserve, and analyze geochemical samples are described. Data quality is evaluated on the basis of analyses of replicate pairs of subsamples, standard reference materials, blanks, and spike additions.

Radiolabeled mercury $\left({ }^{203} \mathrm{Hg}(\mathrm{II})\right)$ was used to determine microbial mercury-methylation potential rates for 11 samples collected from three reservoir locations and various depths in the sediment profile. Ancillary geochemical parameters associated with sulfur, iron, and carbon biogeochemistry were assayed in these same subsamples. Basic, summary statistics are given regarding the spatial variation (longitudinal and vertical) of $\mathrm{Hg}_{\mathrm{T}}, \mathrm{MeHg}$, and the ratio of $\mathrm{MeHg}$ to $\mathrm{Hg}_{\mathrm{T}}$ in Englebright Lake sediments. A quantitative statistical analysis of the relationships between grain-size distribution and concentrations of $\mathrm{Hg}_{\mathrm{T}}, \mathrm{MeHg}$, loss on ignition, and other sediment properties will be published separately. 


\section{Acknowledgments}

Funding for this project was provided by the California Resources Agency. Terry Mills, Rebecca Fris, and Brendan Reed of the CALFED Bay-Delta Program and the California Bay-Delta Authority assisted with project management and coordination with a large and active stakeholder group, the Upper Yuba River Studies Program Workgroup. John Clerici of Circlepoint, Inc. (formerly Public Affairs Management) also assisted with stakeholder coordination. David and Carol Munro and the staff at Skipper's Cove Marina assisted with logistical support during the coring campaigns. Rick Humphreys of the California State Water Resources Control Board (Sacramento, California) assisted with field work. The following staff members of the USGS (including contract employees through the California State University Sacramento Foundation) assisted with chemical and physical analyses of sediment samples: Jennifer Agee, Carlin Dare, Heather Harms, Hillary Harms, Le Kieu, Gary Schneider, and Ryan Wooley (Menlo Park, California); Dale Peart, Terry Plowman, David Roth, and Howard Taylor (Boulder, Colorado); and David

Krabbenhoft, Mark Olson, and Shane Olund (Middleton, Wisconsin). The staff of the Battelle Marine Sciences Laboratory (Sequim, Washington) assisted with analyses of total mercury and methylmercury.

\section{Reservoir Sampling}

The sample locations for the deep and shallow coring campaigns of 2002 are shown in figures 2 and 3. For additional information on sampling locations, sample numbering conventions, and core handling, see Snyder and others (2004a). Several series of subsamples were taken from the deep cores (table 1). Details are provided below regarding subsampling methods and the handling and preserving of subsamples prior to analysis.

\section{Deep Coring Campaign}

The deep coring campaign was conducted on the DOSECC (Drilling, Observation, and Sampling of the Earth's Continental Crust, http://www.dosecc.org/) research drilling company's GLAD200 rig (Global LAke Drilling, 200-m maximum depth of water plus sediment), mostly using a hydraulic-piston apparatus that was advanced $3 \mathrm{~m}$ per run (Snyder and others, 2004a). Cored sediment was recovered in clear, plastic liners approximately $7 \mathrm{~cm}$ (centimeter) in diameter. Deep coring penetrated the full thickness of material deposited after 1940 at six locations in the reservoir; the cores reached a maximum depth of $32.8 \mathrm{~m}$ below the reservoir floor (Snyder and others, 2004a). Cores were cut into sections $1.5 \mathrm{~m}$ or less (depending on recovery) in length and capped at both ends on the drilling platform. Core depths were recorded relative to a fixed reference datum, the elevation of the Englebright
Dam spillway (160.60 m above sea level), as explained by Snyder and others (2004a). Cores were kept chilled until splitting, which was done at the USGS laboratory in Menlo Park, California. Before splitting, multi-sensor logging was done to determine compressional wave ( $\mathrm{p}$-wave) velocity, wet bulk density, and magnetic susceptibility (Snyder and others, 2004a). After splitting down the long axis, a dual-blade cutting tool was used to slice the liner, and then a thin wire was drawn through the core section to separate the unconsolidated sediment into two halves. The two halves were then assigned for working and archive purposes. The archive half of each section was photographed in $30-\mathrm{cm}$ lengths using a digital camera.

Immediately after splitting, the working half of the core was subsampled to determine values for parameters that can change with exposure to the air. These parameters included moisture content (Snyder and others, 2004a) and methylmercury concentration (this report). The MEM (MEthylMercury) series of subsamples was taken for the primary purpose of methylmercury analysis. In representative core sections from a range of depths at each sampling location, 1 or 2 subsamples were taken for the MEM series by removing a series of sediment plugs from the cores using an $\sim 1-\mathrm{cm}$ diameter syringe over an $\sim 10$-cm interval. Care was taken to subsample material at least $\sim 0.5 \mathrm{~cm}$ from the core liner to avoid the effects of post-coring chemical reactions (such as iron oxidation) that could have occurred in the sediment in contact with the liner. Subsamples were divided in half and stored in pre-cleaned, acid-washed, glass jars (Environmental Sampling Supply, Inc., Oakland, Calif., model PC0125). The half of the subsample that was collected for analysis of methylmercury and total mercury was frozen immediately. The other half was chilled and used for analysis of grain-size distribution and loss on ignition (results reported by Snyder and others, 2004b).

At each coring location, 2 to 5 boreholes were cored to retrieve a continuous section of the stratigraphy, despite material lost between core pushes (Snyder and others, 2004a). With the exception of site 2 in the upper reservoir area, drilling at each location penetrated to the pre-reservoir surface digitized from topographic maps provided by the U.S. Army Corps of Engineers (Childs and others, 2003). Direct evidence of reaching the pre-reservoir surface was the recovery of very coarse (cobble-sized) material from the pre-dam river bed (Childs and others, 2003; Snyder and others, 2004a). After the initial logging and description phase was completed for most of the core sections, the core depth estimates were refined, and then resulting stratigraphy for each hole was graphed and plotted. This working stratigraphy provided a structure for a composite subsampling scheme that sought to retrieve a set of material that was as continuous as possible. This material was termed the $\mathrm{Y}$ series of subsamples (for example, the series collected at site 1 from boreholes 1A, 1B, 1C, and 1D was 1Y). Each subsample included about $10-100 \mathrm{~cm}$ of material. These subsamples were collected using a U-shaped channel sampler having a $1-\mathrm{cm}^{2}$ or $4-\mathrm{cm}^{2}$ cross-sectional area. The channel sampler was made from white Delrin $\AA$, an acetal 


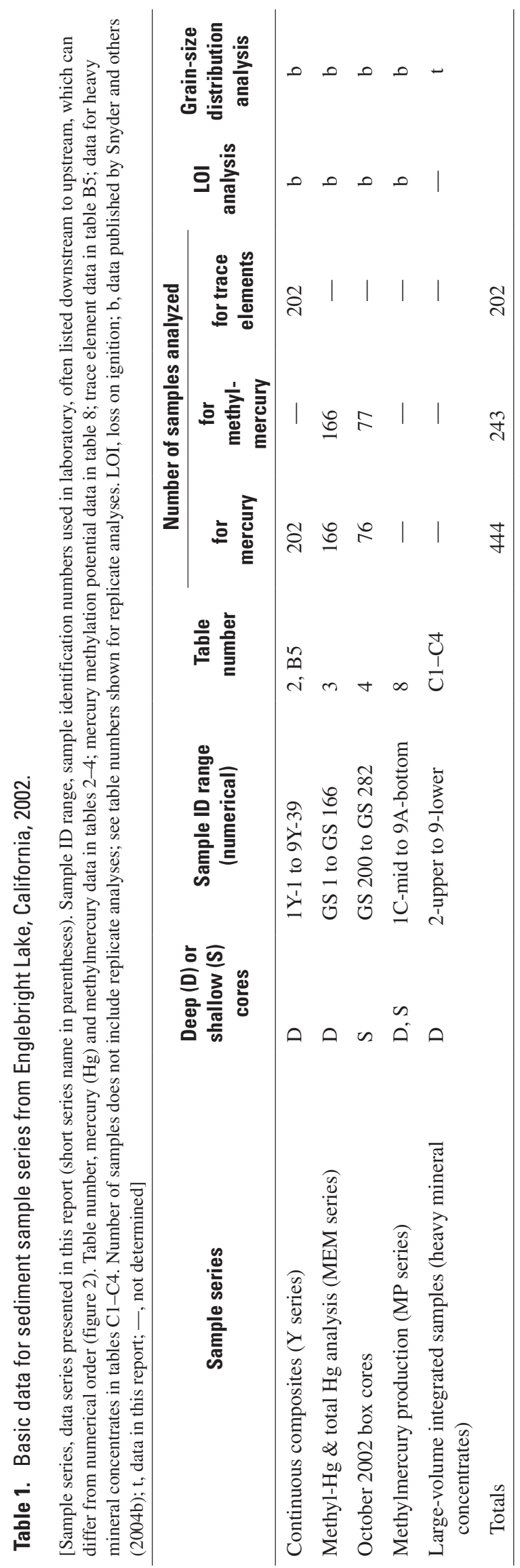


homopolymer. The length of each individual subsample was determined by the stratigraphic layering. Each subsample was divided into at least two splits, which were placed in pre-cleaned glass jars and chilled. One split was used for analysis of grain-size distribution and loss on ignition (Snyder and others, 2004b). The other split was used for geochemical analysis of total mercury, other trace elements, and major elements (this report). As a quality-control check, we collected additional material from selected intervals to make replicate subsamples (labeled " 1 of 2 " and " 2 of 2 ") for each type of analysis.

The first step in the Y-series subsampling from each coring location was generally to identify a "master" borehole that included the most complete recovery. This borehole was used for subsampling as much as possible to minimize the uncertainty created by hole-to-hole correlations. The first subsample collected from each coring location was the uppermost material recovered, as indicated by the properties of the material (usually fine grained, poorly consolidated, and high water content) and the core depths. The subsampling then continued in the same core whenever possible, shifting to adjacent boreholes when needed to fill in gaps in the "master" borehole, to ensure a record as continuous as possible. These shifts were based upon direct, visual correlations of the stratigraphy whenever possible and the estimated core depths in some cases where the visual correlations could not be made with confidence. Rarely, short gaps in the series of subsamples were unavoidable due to incomplete recovery of a stratigraphic unit from all of the parallel holes. At the base of each coring location, an effort was made to include the lowermost material recovered, generally based on the core-depth estimates. After subsampling was completed for each coring location, the depth interval for each subsample was computed on the basis of the "master" hole that contained the majority of the material.

Y-series subsamples from location 4 (labeled 4Y-1 through 4Y-34) were analyzed in their entirety (without sieving) for total mercury, other trace elements, and major elements. To achieve homogeneity, subsamples first were crushed using a tungsten-carbide ball mill and then were split using a stainless-steel sediment-splitting device. Because of the relatively coarse grain size in cores from the upper part of the reservoir (sites 7, 8, and 9; fig. 2), Y-series subsamples from these locations were sieved using a nylon screen with an opening size of $0.06 \mathrm{~mm}$, and only the silt- and clay-sized material that passed through the screen was analyzed. Y-series subsamples from the site nearest Englebright Dam (site 1) were also sieved so that the chemistry of the silt-and-clay fraction could be compared with that at the sites in the upper part of the reservoir.

Six subsamples used to determine potential rates of methylmercury production (or $\mathrm{Hg}$ Methylation Potential [the MP series]) were taken from deep cores (2-25 m below reservoir floor). Two subsamples each were taken from sites 1, 4, and 9 (fig. 2). To our knowledge, these samples represent the deepest sediment depths for which microbial mercury transformations have been examined in any system to date.

Bulk samples used to prepare heavy mineral concentrates and to estimate gold content consisted of samples from four of the deep coring locations, focusing on the upstream part of the reservoir (sites 5/7, 9, 3/8, and 2; fig. 2). Relatively large volumes of sediment were necessary because of expected inhomogeneity (the "nugget effect"). The working halves of several split-core sections were combined to make each composite sample, integrating representative parts of the reservoir stratigraphy. Three composites representing the upper, middle, and lower parts of the reservoir deposit were prepared from samples taken at each of two locations (sites 5/7 and 3/8); two composites representing the upper and lower parts of the deposit were prepared at site 9; and a single composite representing the upper part of the deposit at site 2 brought the total number of composite samples to nine. (For additional details, see Snyder and others, 2004a.)

\section{Shallow Coring Campaign}

At each shallow coring location (fig. 3), box cores and gravity cores were collected. The box cores were used for geochemical subsampling and the gravity cores were used for mapping of stratigraphic properties. Sampling and processing were done from a pontoon boat. Samples were box cored using an Eckman dredge, a stainless-steel box $30 \mathrm{~cm}$ on each side, which penetrated about 6 to $20 \mathrm{~cm}$ into the sediment and provided an undisturbed sample of the sediment-water interface. Immediately after collection, subsamples were taken from each box using 7-cm-diameter clear polycarbonate (Lexan $囚)$ core tubes. A plunger apparatus was inserted into the bottom of each core tube and the sediment was pushed toward the top, expelling the overlying water. The core tubes were capped temporarily and transferred to a glove bag filled with inert gas (nitrogen, $\mathrm{N}_{2}$ ). Inside the glove bag, material was pushed through the top of the core tube in intervals of $1 \mathrm{~cm}, 2 \mathrm{~cm}$, or $4 \mathrm{~cm}$. A polycarbonate ring of the appropriate length was placed on the top of the core tube. Once the material filled the ring, an acid-cleaned plastic sheet was used to separate the material in the ring from the rest of the sediment core. The material above the plastic sheet was then transferred to a pre-cleaned glass jar $(60 \mathrm{~mL})$, in which the sample was homogenized with a plastic spatula and from which split subsamples were removed. One of these split subsamples was frozen immediately after collection and used for analysis of methylmercury and total mercury. Another split subsample, subsequently analyzed for grain-size distribution and loss on ignition (Snyder and others, 2004b), was stored chilled. Additional subsamples were taken for the purpose of analyzing radioisotopes, including ${ }^{7} \mathrm{Be},{ }^{137} \mathrm{Cs}$, and ${ }^{210} \mathrm{~Pb}$, the results of which will be reported separately. 


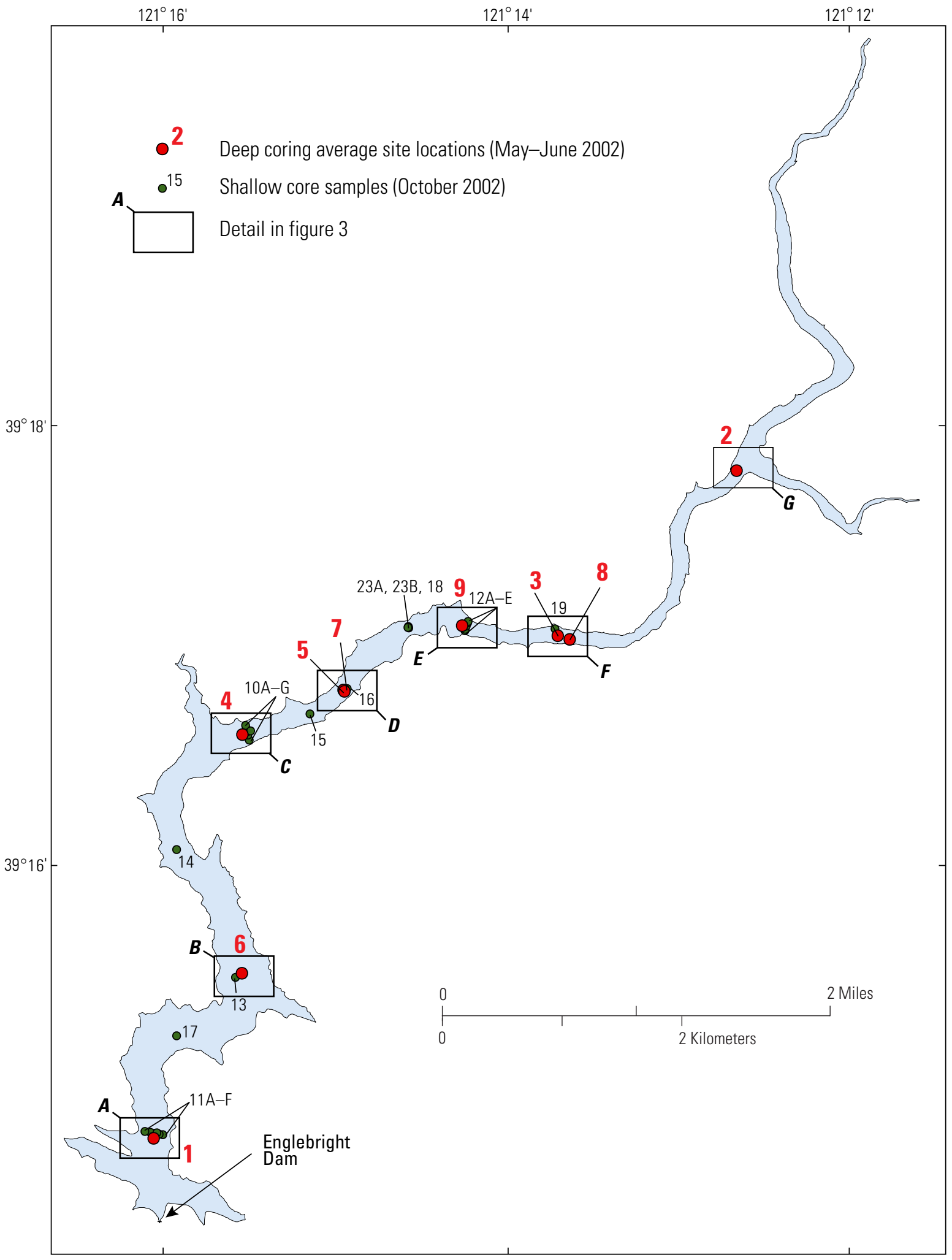

Figure 2. Locations of deep and shallow coring, Englebright Lake, California. Modified from Snyder and others (2004b). 

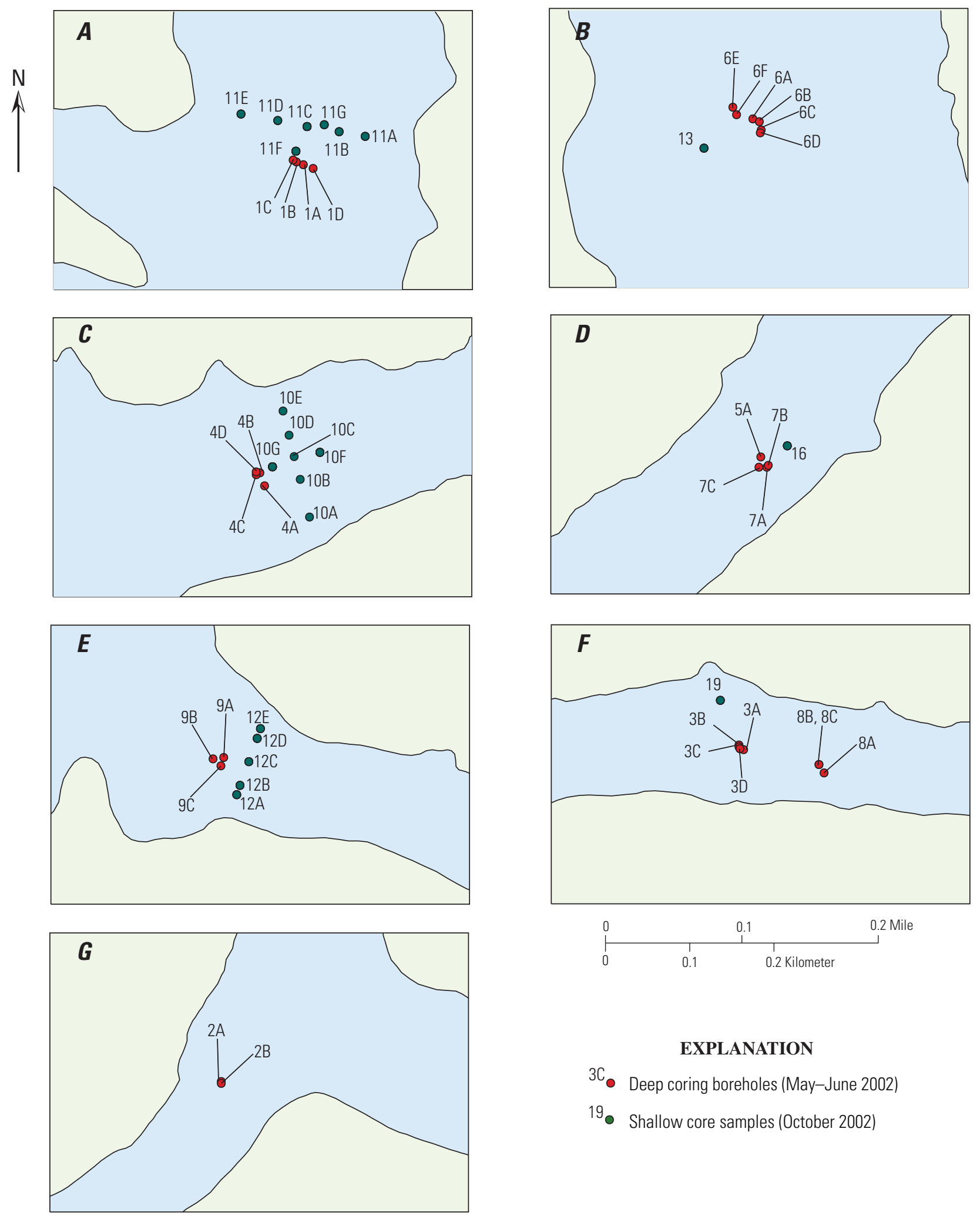

\section{EXPLANATION}

3C Deep coring boreholes (May-June 2002)

19. Shallow core samples (October 2002)

Figure 3. Detailed maps of sampling locations at Englebright Lake, California. See figure 2 for location of each box. Modified from Snyder and others (2004b). 
Shallow sediment subsamples used to determine potential rates of mercury methylation were taken from $0-4 \mathrm{~cm}$ below the reservoir floor at three shallow sites $(10,11$, and 12) and $4-8 \mathrm{~cm}$ at two sites (10 and 11). These shallow sites were located close to sites 1, 4, and 9 (figs. 2 and 3) where subsamples had been taken for similar analysis from deep cores. Methods of sample collection and processing were identical to those described for the other shallow samples with the exception that larger $(500 \mathrm{~mL})$ glass jars were used and they were filled to the top to exclude oxygen. For these five shallow mercury-methylation subsamples, ancillary geochemical parameters were assayed: microbial sulfate reduction rates, sulfur speciation (sediment acid volatile sulfide, total reduced sulfur, and pore-water sulfate), iron speciation (sediment acid extractable iron(II), amorphous iron(III), crystalline iron(III), and pore-water iron(II)), pore-water chloride, and dissolved organic carbon.

\section{Laboratory Methods}

Laboratory methods were chosen on the basis of past laboratory performance and data-quality objectives for the present study. Total mercury, methylmercury, trace and major elements, and mercury methylation potential were analyzed, and heavy minerals were identified. Concentrations of mercury, methylmercury, and trace metals in sediment are reported on a dry basis throughout this report.

\section{Total Mercury}

Total mercury $\left(\mathrm{Hg}_{\mathrm{T}}\right)$ in sediment was analyzed by two different laboratories for this study: the USGS laboratory in Boulder, Colorado (USGS-Boulder), and the Battelle Marine Sciences Laboratory (BMSL) in Sequim, Washington. The Y-series subsamples were analyzed by the USGS-Boulder laboratory; the MEM series from the deep cores and the shallow core subsamples were analyzed primarily by the BMSL. As a check on quality control at the BMSL, fifteen split subsamples from the MEM series were also analyzed by the USGS Wisconsin District Mercury Laboratory (USGS-WDML) in Middleton, Wisconsin.

The USGS-Boulder laboratory analyzed $\mathrm{Hg}_{\mathrm{T}}$ in sediment using cold-vapor atomic fluorescence spectrometry (CVAFS) after digestion using a mixture of distilled nitric, hydrochloric, and hydrofluoric acids in a closed Teflon ${ }^{\circledR}$ bomb (Hayes, 1993). Mercury stock and standard solutions were made from Puratronic grade (99.9995 percent) mercuric chloride $\left(\mathrm{HgCl}_{2}\right)$ salt (Johnson Matthey Public Limited Company) and preserved in a solution of high-purity nitric acid and primarystandard grade potassium dichromate. Deionized (DI) water (American Society for Testing and Materials [ASTM] type 1, $18 \mathrm{M} \Omega$-cm [megaohm-centimeter]) was used for preparing all standards and reagent solutions. A solution of 3-percent hydrochloric acid (volume:volume, hydrochloric acid:DI water) was used to prepare a 2-percent stannous chloride $\left(\mathrm{SnCl}_{2}\right)$ solution (wt:volume, stannous chloride:3-percent hydrochloric acid), which was used to reduce mercury to its elemental form in the cold vapor reactor. The vapor was transported to the detector using a stream of argon gas. Trace concentration levels of mercury were measured using an automated CVAFS analyzer (PS Analytical) using methods described previously (Roth,1994; David A. Roth, U.S. Geological Survey, written commun., 1999). Instrumental parameters for the CVAFS mercury analysis were the same as those described by Alpers and others (2000). Peak-height intensities of unknown samples were compared to a six-point calibration curve prepared from aqueous standards ranging in concentration from 0 to $50 \mathrm{ng} / \mathrm{L}$ (nanogram per liter), preserved with potassium dichromate and nitric acid.

The BMSL analyzed $\mathrm{Hg}_{\mathrm{T}}$ in sediment by cold vapor atomic absorption spectrometry (CVAAS). The procedure (Lasorsa, 2003a) is a modified version of U.S. Environmental Protection Agency (USEPA) method 245.5 (U.S. Environmental Protection Agency, 1991). The USEPA method was modified by eliminating the use of potassium permanganate in the digestions because it was a source of mercury contamination. A digestion using strong acids was carried out in a closed Teflon bomb. Mercury ions in the digestate were reduced by acidic $\mathrm{SnCl}_{2}$ to $\mathrm{Hg}^{+}$and then carried through a flow cell on a stream of inert gas (argon). The luminous intensity of monochromatic light that passes through the sample was compared with the luminous intensity of the same light that passed through a reference beam using a photometric detector at a wavelength of 253.7 nanometers. The attenuation of the light is directly proportional to the concentration of mercury vapor, which was quantified using a standard curve. Mercury stock standards were purchased from High Purity Standards. An intermediate standard with a mercury concentration of $10 \mathrm{mg} / \mathrm{L}$ (milligram per liter) was prepared in 1 percent $\mathrm{HCl}$. To develop the standard curves, five mercury working standards (typically ranging from $0.5 \mu \mathrm{g} / \mathrm{L}$ [microgram per liter] to $12.5 \mu \mathrm{g} / \mathrm{L}$ ) were prepared by diluting the intermediate standard.

\section{Methylmercury}

Monomethylmercury $(\mathrm{MeHg})$ in sediment was analyzed for this study primarily by the BMSL. (For the remainder of this report, "methylmercury" [also abbreviated as $\mathrm{MeHg}$ ] is used instead of "monomethylmercury"; note that other methylated forms of mercury such as dimethylmercury may have been present but were not included in methylmercury analyses reported in this study.) As a quality assurance check, fifteen replicate subsamples were analyzed by the USGSWDML. MeHg can be difficult to measure in solids because 
of matrix interferences and the possibility of unintentionally producing MeHg during distillation (Bloom and others, 1997; Hintelmann and others, 1997; Hammerschmidt and Fitzgerald, 2001). Therefore, extraction methods using methylene chloride $\left(\mathrm{CH}_{2} \mathrm{Cl}_{2}\right)$ were used by both laboratories to minimize $\mathrm{MeHg}$ artifacts.

At the BMSL, MeHg in sediment was analyzed by CVAFS using a procedure (Lasorsa, 2003b) based on Bloom (1989) and equivalent to USEPA method 1630. A minimum of $200 \mathrm{mg}$ (milligrams) of sediment was placed in a $50-\mathrm{mL}$ (milliliter) centrifuge tube along with $5 \mathrm{~mL}$ of acidic potassium bromide (KBr) solution, $1 \mathrm{~mL}$ of 1 molar copper sulfate $\left(\mathrm{CuSO}_{4}\right)$, and $10 \mathrm{~mL}$ of $\mathrm{CH}_{2} \mathrm{Cl}_{2}$. After one hour of vigorous shaking, the samples were centrifuged for 30 minutes at 2,000 rpm (revolutions per minute). Immediately after centrifuging, $2 \mathrm{~mL}$ of the $\mathrm{CH}_{2} \mathrm{Cl}_{2}$ layer was transferred by pipette into a distillation vial along with $45 \mathrm{~mL}$ of reagent water. The distillation vial was capped and placed in a heating block and connected to $\mathrm{N}_{2}$ carrier gas flowing at $60 \mathrm{~mL} / \mathrm{min}$ (milliliter per minute). The block was heated to $45^{\circ} \mathrm{C}$ until all of the $\mathrm{CH}_{2} \mathrm{Cl}_{2}$ evaporated. The $\mathrm{pH}$ was adjusted to 4.9 (to maximize ethylation potential) using acetate buffer. The sample was then reacted with an ethylating reagent for 17 minutes, after which the sample was purged with argon into a Carbotrap (Supelco, Inc.). Methyl-ethylmercury that resulted from the ethylation of methylmercury in the sample was then quantified using CVAFS.

Methylmercury in sediment was analyzed at the USGSWDML by inductively coupled plasma mass spectrometry (ICP-MS) using extraction methods very similar to those used at the BMSL. The extraction methods used at the WDML are described by DeWild and others (2004), who adopted the technique of Hintelmann (1999) for extracting $\mathrm{MeHg}$ from solids to eliminate formation of $\mathrm{MeHg}$ in samples containing high inorganic mercury levels. Solids (0.5 to $1.0 \mathrm{~g}$ [gram]) were placed into a centrifuge tube to which $5 \mathrm{~mL}$ of acidic $\mathrm{KBr}$ solution, $1 \mathrm{~mL}$ of 1 molar $\mathrm{CuSO}_{4}$, and $10 \mathrm{~mL}$ of $\mathrm{CH}_{2} \mathrm{Cl}_{2}$ were added sequentially. The mixture was allowed to react for an hour and then was shaken for an hour to ensure complete extraction of the MeHg. Following the shaking, the samples were centrifuged to break any emulsion that had formed. An aliquot of $2 \mathrm{~mL}$ of the $\mathrm{CH}_{2} \mathrm{Cl}_{2}$ was cleanly transferred to a vial containing reagent water. Each vial was placed in a heating block until all $\mathrm{CH}_{2} \mathrm{Cl}_{2}$ evaporated and the $\mathrm{MeHg}$ was extracted back into the reagent water. The $\mathrm{pH}$ of the extractant was adjusted to 4.9 (to maximize ethylation potential) using acetate buffer. The extract then was ethylated using sodium tetraethyl borate $\left(\mathrm{NaBEt}_{4}\right)$ and allowed to react for 15 minutes. After the reaction, the extractant was purged with $\mathrm{N}_{2}$ gas for 20 minutes, and the ethylated forms of $\mathrm{Hg}$ were collected on a sample trap containing Carbotrap (Supelco, Inc.). The ethylated Hg species were desorbed thermally from the sample trap, separated using a gas chromatographic (GC) column, reduced using a pyrolytic column, and quantified using inductively coupled plasma-mass spectrometry (ICP-MS). Deionized water blanks were analyzed as part of each analytical batch; reported results were blank-corrected.

\section{Trace and Major Elements}

Trace and major elements in sediments from the Y-series subsamples were analyzed using inductively coupled plasma (ICP) methods by the USGS-Boulder laboratory. Both atomic emission spectroscopy (ICP-AES) and mass spectrometry (ICP-MS) were used. Sediments in subsamples collected for analysis of trace and major elements were completely dissolved using an $\mathrm{HCl}-\mathrm{HNO}_{3}-\mathrm{HF}$ acid, microwave, total-digestion procedure (Hayes, 1993). The digested subsamples were diluted at 1:10 (volume:volume, digest:DI water) with $18 \mathrm{M} \Omega-\mathrm{cm}$ DI water and were preserved with distilled nitric acid. Major elements, including calcium $(\mathrm{Ca})$, iron $(\mathrm{Fe})$, magnesium $(\mathrm{Mg})$, potassium $(\mathrm{K})$, sodium $(\mathrm{Na})$, and sulfur (S), were determined by ICP-AES techniques using a PerkinElmer Optima 3300DV multi-channel emission spectrometer. Using the dual-view (radial and axial) optical configuration provided optimal sensitivity for various elements regardless of concentration. A description of the ICP-AES analysis conditions and procedures is given by Garbarino and Taylor (1979). Details of the operational conditions are described by Mitko and Bebek $(1999,2000)$. Concentrations of trace elements other than mercury were determined by ICP-MS using a Perkin Elmer Elan Model 6000. Aerosols of acidified aqueous samples were introduced into the spectrometer with a cone-spray pneumatic nebulizer. Multiple internal standards (indium, iridium, and rhodium), which covered the mass range, were used to normalize the system for drift. Details of the specific analysis techniques, procedures, and instrumental settings are described by Garbarino and Taylor (1996) and Taylor (2001).

\section{Mercury Methylation Potential}

Standard radiotracer methods were used to measure potential rates of microbial $\mathrm{MeHg}$ production, $\mathrm{Hg}$ (II) methylation, at the USGS laboratory in Menlo Park, Calif.

(Marvin-DiPasquale and others, 2003). An amendment containing $1.5 \mu \mathrm{Ci} / 100 \mu \mathrm{L}$ (microcurie per 100 microliters) of radiolabeled divalent mercury ${ }^{203} \mathrm{Hg}$ (II), having a half-life of 46.5 days, was used for the $\mathrm{MeHg}$-production rate assay. The ${ }^{203} \mathrm{Hg}$ (II) specific activity of the injection solution was $1.15 \mathrm{mCi} / \mathrm{mg}$ (millicurie per milligram), which resulted in a total $\mathrm{Hg}(\mathrm{II})$ amendment of $436 \mathrm{ng} / \mathrm{g}$ (nanogram per gram) wet sediment per 3.0-g sediment subsample. Sample sets for each interval assayed for microbial $\mathrm{Hg}$ (II)-methylation potential consisted of duplicate, live (incubated) samples and one control sample in which microbes were killed by flash freezing at the beginning of the experiment (time zero). $\mathrm{MeHg}$ production sample sets were incubated for 4 hours at $12-16^{\circ} \mathrm{C}$ for shallow subsamples or for 24 hours at $19^{\circ} \mathrm{C}$ for deep subsamples. It was assumed that the $\mathrm{Hg}(\mathrm{II})$-methylation process 
was first-order for the purposes of calculating potential rates (Marvin-DiPasquale and others, 2003). Potential rates were subsequently calculated as the product of the radiotracerderived rate constant and the final concentration of radiotracer amendment in the whole sediment, and were thus independent of the amount of $\mathrm{Hg}$ (II) that might have been present originally in each subsample.

The five shallow sediment samples that were assayed for $\mathrm{Hg}(\mathrm{II})$ methylation potential were also subsampled to determine several ancillary chemical parameters, including microbial sulfate reduction, $\mathrm{pH}$, oxidation-reduction (redox) potential, loss on ignition, acid volatile sulfide, total reduced sulfur, and iron speciation. Sulfate-reduction samples were subsampled and incubated in a manner analogous to that for the mercury methylation rate assays, including replicates consisting of two live (incubated) and one killed control sample per site and depth. Samples were amended with $1.0 \mu \mathrm{Ci} / \mathrm{sam}$ ple of carrier-free ${ }^{35} \mathrm{SO}_{4}^{2-}$ and assayed according to Jørgensen (1978). The $\mathrm{pH}$ and redox potential were determined by inserting an electrode directly into sediment. Weight loss on ignition was measured as a proxy for organic content (American Public Health Association, 1981). Two forms of sulfur—acid volatile sulfide and total reduced sulfur-were determined using methods described by Ulrich and others (1997). Iron speciation analyses included acid-extractable Fe(II), acid-extractable amorphous Fe(III), and crystalline Fe(III) (Lovley and Phillips, 1987; Roden and Zachara, 1996). Organic content and both forms of solid-phase sulfur were measured in duplicate samples from each of the five shallow sediment samples. Dissolved organic carbon (DOC) concentrations were assessed by adding DI water (Milli-Q, ASTM type 1, $18 \mathrm{M} \Omega$-cm; $10 \mathrm{~mL})$ to the sediment $(10 \mathrm{~g})$ to obtain enough pore water for analysis. The exact weight of the sediment and the water added per tube was recorded, and subsequent pore-water analyte concentrations were calculated taking this pore-water dilution into account. Samples were shaken until each became a homogenous slurry, which was then centrifuged at 3,000 rpm for 15 minutes in $45-\mathrm{cm}^{3}$ polystyrene, screw-cap tubes. The resulting supernatant was filtered $(0.45-\mu \mathrm{m}$ nylon syringe, inline filter) inside an oxygen-free glove bag. The DOC samples were frozen until analysis, which was done using high-temperature oxidation with infrared detection (Qian and Mopper, 1996). Pore-water sulfate samples were preserved by freezing under anoxic conditions and assayed via ion chromatography (Dionex, 1992). Pore-water iron(II) was preserved by adjusting $\mathrm{pH}$ to $<2$ with 10 -percent $\mathrm{HCl}$ and assayed via the colorimetric Ferrozine assay (Stookey, 1970).

\section{Heavy Minerals}

Heavy-mineral concentrates were prepared for the composite samples by Cal Sierra Development Company in Marysville, California. First the material was screened using a 9.5-mm sieve. The material passing through the sieve was processed on a shaker table, yielding a concentrated sample of minerals with greater density, referred to as a heavy-mineral concentrate. The concentrate was then screened using stainless-steel sieves of the following sizes (in $\mathrm{mm}$ ): 4.75 , $2.36,1.18,0.60,0.30,0.15,0.075$, and 0.063 . The mass passing through each sieve was measured, and the material was retained for microscopic examination. Observations were made using a stereo microscope and a scanning electron microscope (SEM) with energy dispersive spectrometer (EDS).

\section{Quality Assurance and Quality Control}

A variety of procedures was used to ensure high data quality and to quantify accuracy and precision when appropriate. Digestion blanks were prepared and analyzed to determine the level of contamination, if any, in the digestion equipment and reagents. Spikes were added to blanks and to a subset of the analyzed samples to ensure that analyses accurately measured concentrations in the range of sample matrixes encountered. Replicates were digested to form a subset of the analyzed samples to assess variability in laboratory procedures and analytical methods. Replicate splits taken at the time of initial subsampling are referred to as core replicates, whereas replicate splits taken at a later time by the analyzing laboratory are referred to as laboratory replicates. Fifteen split subsamples were analyzed for total mercury and methylmercury at two laboratories (BMSL and USGS-WDML) for comparative purposes. At each laboratory, standard reference materials (SRM) were digested along with analyzed samples; results from analysis of SRMs were compared with certified values to determine analytical accuracy.

\section{Total Mercury}

Quality-assurance analyses of SRMs for total mercury $\left(\mathrm{Hg}_{\mathrm{T}}\right)$ at two of the laboratories used in this study (table Al) indicate a high level of accuracy and low variability. The USGS-Boulder laboratory used NIST 2704, Buffalo River Sediment, provided by the National Institute of Standards and Technology. For this SRM, 24 of 27 analyses were within the range of 85 to 115 percent of the certified value, and the average was 101 percent. The BMSL used IAEA-356, provided by the International Atomic Energy Agency. For IAEA-356, all 14 analyses were within the range of 98 to 113 percent of the certified value; the average was 103 percent.

Other quality-assurance procedures used by the USGSBoulder laboratory and the BMSL in conjunction with their $\mathrm{Hg}_{\mathrm{T}}$ determinations included analyses of blanks and spike additions. Two types of spikes were prepared, one by adding a known amount of $\mathrm{Hg}$ to blanks (referred to as blank spikes) and the other by adding a known amount of $\mathrm{Hg}$ to environmental samples that were previously analyzed (referred to as matrix spikes). 
At the BMSL, three laboratory blanks were analyzed with each of the 12 batches of samples. Total mercury was detected in only 3 of the 36 blanks. In those 3 blanks, the detected $\mathrm{Hg}_{\mathrm{T}}$ concentrations were less than $10 \mathrm{ng} / \mathrm{g}$, which is twice the method detection limit (MDL) of $5 \mathrm{ng} / \mathrm{g}$. Three of the environmental samples had $\mathrm{Hg}_{\mathrm{T}}$ concentrations less than the MDL, whereas most of the samples had concentrations more than 10 times greater than the MDL. Because of the small number of laboratory blanks with detected concentrations of $\mathrm{Hg}_{\mathrm{T}}$ at the BMSL, the data were not blank-corrected (a procedure in which the amount detected in laboratory blanks is systematically subtracted from the results for environmental samples).

A total of 28 blank spikes were analyzed at the BMSL for $\mathrm{Hg}_{\mathrm{T}}$. Recoveries ranged from 43 to 103 percent; the average value was 91.8 percent and the median value was 97.5 percent. Three blank spikes that were originally outside the laboratory's data quality objective (75 to 125 percent recovery) were reanalyzed, according to the laboratory's standard operating procedure, and all but one met the laboratory's data-quality objectives.

Twenty-five pairs of $\mathrm{Hg}_{\mathrm{T}}$ matrix spikes and matrix spike replicates were analyzed by the BMSL with the samples. Recoveries for these matrix spikes ranged from 92 percent to 107 percent for $\mathrm{Hg}_{\mathrm{T}}$, within the laboratory's data-quality objectives. Variability between replicates is described using Relative Percentage Difference (RPD), defined as the 100 times the absolute value of the difference between two concentrations divided by their average. The RPD between the matrix spikes and matrix spike replicates ranged from 0 to 8 percent, well within the laboratory's data-quality objective (RPD values less than 25 percent).

The USGS-Boulder laboratory and the BMSL analyzed a total of 40 pairs of replicate subsamples for $\mathrm{Hg}_{\mathrm{T}} ; 31$ pairs were laboratory replicates and 9 pairs were core replicates (table A2). Each pair of replicate analyses represented two separate digestions of sediment, so variations in results could have been caused by sample inhomogeneity as well as variability in the analytical determinations. Median values of RPD were 5.8 percent for the 31 laboratory replicates and 13.2 percent for the 9 core replicates. The USGS-Boulder laboratory determined the concentrations of $\mathrm{Hg}_{\mathrm{T}}$ by analyzing each digested Y-series subsample three times and computing the average; the concentrations and standard deviations are given in table 2 . The standard deviations were typically less than 2 percent of the average concentrations.

An additional check on data quality is provided by the analyses of $\mathrm{Hg}_{\mathrm{T}}$ in 15 split subsamples that were analyzed by the BMSL and the USGS-WDML. The median of the 15 RPD values for $\mathrm{Hg}_{\mathrm{T}}$ was 11.1 percent, and 12 of the $15 \mathrm{RPD}$ values were less than 15 percent (table A5). RPD values for the other three subsamples were 17, 53, and 109 percent. A correlation plot showing results of the $\mathrm{Hg}_{\mathrm{T}}$ analyses for these 15 split subsamples from the two laboratories (fig. Al) shows that data are distributed on both sides of the 1:1 line, indicating that there is no systematic difference in concentrations.

\section{Methylmercury}

Two SRMs for methylmercury (MeHg), IAEA-356 and IAEA-405, were analyzed by the BMSL along with the samples for this study (table A3). These two SRMs were certified for MeHg by the International Atomic Energy Agency (Horvat and others, 1994; Wyse and others, 2004). Some of the laboratories participating in the certification of these SRMs used the distillation technique, which has since been shown to produce an analytical artifact resulting in inflated values of MeHg (Bloom and others, 1997; Hintelmann and others 1997; Hintelmann, 1999). Therefore, the extraction technique used for MeHg analysis in this study avoids the analytical artifact problem and is now in common use. The extraction method routinely produced $\mathrm{MeHg}$ concentrations in the range of 65-95 percent of the certified values for the two SRMs, which was reasonable considering the different analytical methods; the laboratory's data-quality objective is 67 to 133 percent recovery for MeHg in SRMs. For SRM IAEA-356, 17 of the 18 analyses were in the range of 72-95 percent of the certified value, with one outlier; for SRM IAEA-356, 16 of 19 values for recovery were in the range of 65-91 percent of the certified value with three outliers. Because no more than one of the SRM outliers occurred within an individual batch of samples, these results meet the data-quality objective of the BMSL.

A total of 21 environmental samples were analyzed in replicate for MeHg by the BMSL. Nineteen of the samples had a single replicate (two analyses), one had two replicates (three analyses), and one had three replicates (four analyses), bringing the total number of replicate analyses to 24 (table A4). The multiple replicate analyses were compared as follows: for the sample with two replicates (three analyses), three separate RPD values were calculated; for the sample with three replicates (four analyses), six separate RPD values were calculated, representing all possible combinations (table A4). The median value of RPD for MeHg in all replicates was 10.5 percent and the median value of RPD for the 19 laboratory replicates was 8.8 percent. For all but four of the samples, the RPD values were less than or equal to about 20 percent. The other 4 samples showed higher variability; RPD values ranged from about 40 percent to about 60 percent. The BMSL's data-quality objective for replicate analyses of $\mathrm{MeHg}$ requires that fewer than 35 percent of the replicate pairs have RPD values greater than 35 percent, so the results are within the objective. Three of the five core replicates were among the samples with higher RPD values, and two of these were from cores 11C-B1 and 11C-B2. These cores were taken in separate, parallel tubes from the same Eckman dredge sample (box core), so they were not split samples in the usual sense. In contrast, the other core replicates were made by homogenizing material from a single core interval in a glass jar and then spooning half of the sample into a second jar. In light of the methods used for taking these samples, the higher values of RPD are more likely to have been caused by sample inhomogeneity than by laboratory error. 
Table 2. Mercury data from the Y series of subsamples from deep cores, Englebright Lake, California, May-June 2002.

[Analyses by U.S. Geological Survey laboratory in Boulder, Colo. First digit of sample ID and core ID represents coring site, listed in order from downstream to upstream (figure 2). mbls, meters below lake surface (spillway elevation); mblf, meters below lake floor; SD, standard deviation; Y, yes; N, no. ng/g, nanogram per gram; mm, millimeter; cm, centimeter; <, less than]

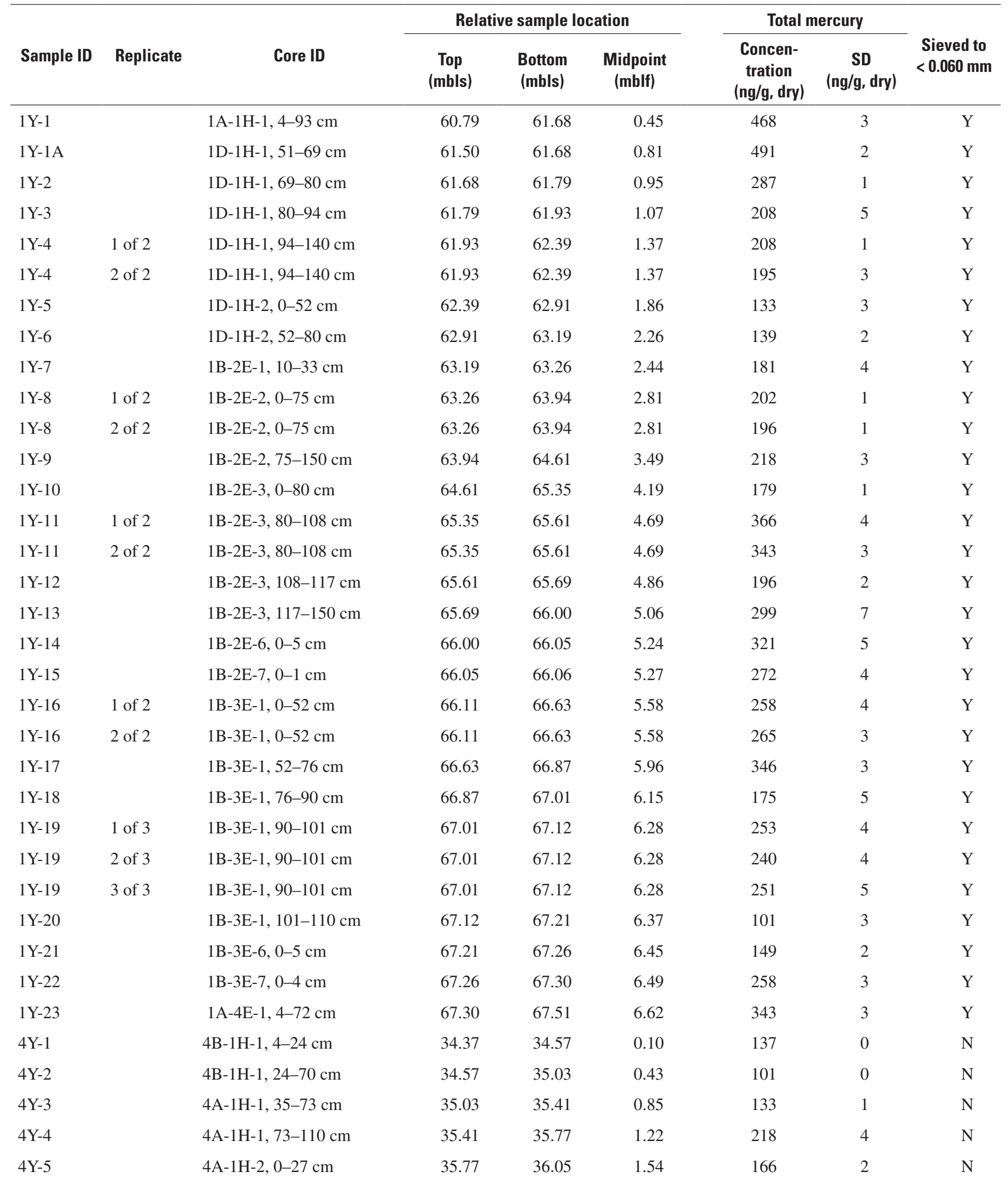


Table 2. Mercury data from the $\mathrm{Y}$ series of subsamples from deep cores, Englebright Lake, California, May-June 2002—Continued.

[Analyses by U.S. Geological Survey laboratory in Boulder, Colo. First digit of sample ID and core ID represents coring site, listed in order from downstream to upstream (figure 2). mbls, meters below lake surface (spillway elevation); mblf, meters below lake floor; SD, standard deviation; Y, yes; N, no. ng/g, nanogram per gram; mm, millimeter; $\mathrm{cm}$, centimeter; <, less than]

\begin{tabular}{|c|c|c|c|c|c|c|c|c|}
\hline \multirow[b]{2}{*}{ Sample ID } & \multirow[b]{2}{*}{ Replicate } & \multirow[b]{2}{*}{ Core ID } & \multicolumn{3}{|c|}{ Relative sample location } & \multicolumn{2}{|c|}{ Total mercury } & \multirow[b]{2}{*}{$\begin{array}{l}\text { Sieved to } \\
<0.060 \mathrm{~mm}\end{array}$} \\
\hline & & & $\begin{array}{c}\text { Top } \\
\text { (mbls) }\end{array}$ & $\begin{array}{l}\text { Bottom } \\
\text { (mbls) }\end{array}$ & $\begin{array}{l}\text { Midpoint } \\
\text { (mblf) }\end{array}$ & $\begin{array}{l}\text { Concen- } \\
\text { tration } \\
\text { (ng/g, dry) }\end{array}$ & $\begin{array}{c}\text { SD } \\
\text { (ng/g, dry) }\end{array}$ & \\
\hline $4 Y-6$ & & $4 \mathrm{~A}-1 \mathrm{H}-2,27-62 \mathrm{~cm}$ & 36.05 & 36.40 & 1.86 & 195 & 0 & $\mathrm{~N}$ \\
\hline $4 Y-7$ & & $4 \mathrm{~A}-1 \mathrm{H}-2,62-150 \mathrm{~cm}$ & 36.40 & 37.27 & 2.47 & 355 & 6 & $\mathrm{~N}$ \\
\hline $4 Y-8$ & 2 of 2 & $4 \mathrm{~B}-2 \mathrm{H}-1,14-124 \mathrm{~cm}$ & 37.27 & 38.38 & 3.46 & 243 & 2 & $\mathrm{~N}$ \\
\hline $4 Y-9$ & & $4 \mathrm{~B}-2 \mathrm{H}-2,0-44 \mathrm{~cm}$ & 38.38 & 38.86 & 4.25 & 231 & 1 & $\mathrm{~N}$ \\
\hline $4 Y-10$ & & $4 \mathrm{~B}-2 \mathrm{H}-2,44-66 \mathrm{~cm}$ & 38.86 & 39.08 & 4.60 & 107 & 1 & $\mathrm{~N}$ \\
\hline $4 \mathrm{Y}-11$ & & 4B-2H-2, 66-78 cm & 39.08 & 39.20 & 4.77 & 148 & 1 & $\mathrm{~N}$ \\
\hline $4 Y-15$ & & 4B-3H-1, 0-47 cm & 40.45 & 41.06 & 6.39 & 279 & 0 & $\mathrm{~N}$ \\
\hline $4 Y-16$ & & $4 \mathrm{~B}-3 \mathrm{H}-1,47-86 \mathrm{~cm}$ & 41.06 & 41.57 & 6.95 & 165 & 1 & $\mathrm{~N}$ \\
\hline $4 Y-17$ & & $4 \mathrm{~A}-4 \mathrm{H}-1,55-108 \mathrm{~cm}$ & 41.57 & 42.10 & 7.47 & 189 & 4 & $\mathrm{~N}$ \\
\hline $4 Y-18$ & & $4 \mathrm{~A}-4 \mathrm{H}-1,108-127 \mathrm{~cm}$ & 42.10 & 42.38 & 7.87 & 266 & 4 & $\mathrm{~N}$ \\
\hline $4 Y-19$ & 1 of 2 & $4 \mathrm{~A}-4 \mathrm{H}-2,9-95 \mathrm{~cm}$ & 42.38 & 43.24 & 8.44 & 251 & 0 & $\mathrm{~N}$ \\
\hline $4 Y-19$ & 2 of 2 & $4 \mathrm{~A}-4 \mathrm{H}-2,9-95 \mathrm{~cm}$ & 42.38 & 43.24 & 8.44 & 680 & 8 & $\mathrm{~N}$ \\
\hline $4 Y-20$ & & $4 \mathrm{~A}-4 \mathrm{H}-2,95-146 \mathrm{~cm}$ & 43.24 & 43.75 & 9.13 & 299 & 4 & $\mathrm{~N}$ \\
\hline $4 Y-21$ & & 4B-4H-1, 26-48 cm & 43.75 & 43.89 & 9.45 & 308 & 6 & $\mathrm{~N}$ \\
\hline $4 Y-27$ & & $4 \mathrm{~A}-5 \mathrm{H}-2,51-101 \mathrm{~cm}$ & 45.39 & 45.86 & 11.26 & 550 & 4 & $\mathrm{~N}$ \\
\hline $4 Y-28$ & & $4 \mathrm{~B}-5 \mathrm{H}-1,0-56.5 \mathrm{~cm}$ & 45.86 & 46.42 & 11.77 & 315 & 3 & $\mathrm{~N}$ \\
\hline $4 Y-29$ & & $4 \mathrm{~B}-5 \mathrm{H}-1,56.5-142 \mathrm{~cm}$ & 46.42 & 47.26 & 12.47 & 295 & 2 & $\mathrm{~N}$ \\
\hline $4 Y-30$ & & $4 \mathrm{~B}-5 \mathrm{H}-2,0-71 \mathrm{~cm}$ & 47.26 & 47.97 & 13.25 & 462 & 3 & $\mathrm{~N}$ \\
\hline $4 Y-31$ & & 4B-5H-2, 71-135 cm & 47.97 & 48.61 & 13.92 & 296 & 3 & $\mathrm{~N}$ \\
\hline $4 Y-32$ & & $4 \mathrm{~B}-5 \mathrm{H}-2,135-250 \mathrm{~cm}$ & 48.61 & 48.76 & 14.32 & 348 & 0 & $\mathrm{~N}$ \\
\hline $4 Y-33$ & & $4 \mathrm{~B}-5 \mathrm{H}-6,0-5 \mathrm{~cm}$ & 48.77 & 48.82 & 14.43 & 439 & 4 & $\mathrm{~N}$ \\
\hline $4 Y-34$ & & $4 \mathrm{~B}-6 \mathrm{H}-1,0-80 \mathrm{~cm}$ & 48.93 & 49.70 & 14.95 & 269 & 2 & $\mathrm{~N}$ \\
\hline 7Y-02 & & $7 \mathrm{C}-1 \mathrm{H}-1,80-117 \mathrm{~cm}$ & 15.13 & 15.50 & 0.98 & 288 & 1 & $\mathrm{Y}$ \\
\hline 7Y-03 & & $7 \mathrm{C}-1 \mathrm{H}-2,0-31 \mathrm{~cm}$ & 15.50 & 15.81 & 1.33 & 246 & 1 & $\mathrm{Y}$ \\
\hline 7Y-04 & 1 of 2 & $7 \mathrm{C}-1 \mathrm{H}-2,31-97 \mathrm{~cm}$ & 15.81 & 16.47 & 1.81 & 240 & 8 & $\mathrm{Y}$ \\
\hline 7Y-04 & 2 of 2 & 7C-1H-2, 31-97 cm & 15.81 & 16.47 & 1.81 & 281 & 4 & Y \\
\hline
\end{tabular}


Table 2. Mercury data from the Y series of subsamples from deep cores, Englebright Lake, California, May-June 2002-Continued.

[Analyses by U.S. Geological Survey laboratory in Boulder, Colo. First digit of sample ID and core ID represents coring site, listed in order from downstream to upstream (figure 2). mbls, meters below lake surface (spillway elevation); mblf, meters below lake floor; SD, standard deviation; Y, yes; N, no. ng/g, nanogram per gram; mm, millimeter; $\mathrm{cm}$, centimeter; <, less than]

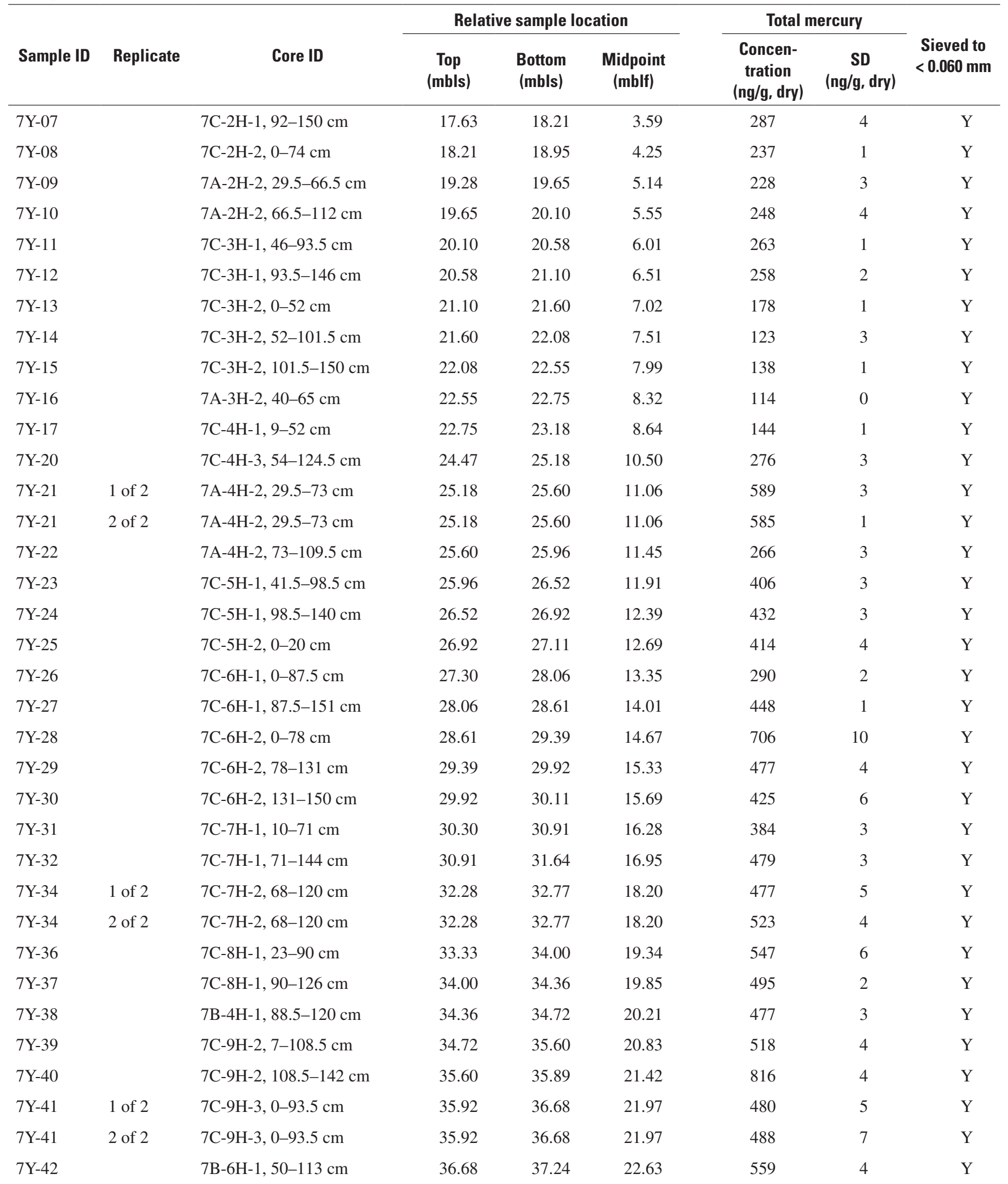


Table 2. Mercury data from the Y series of subsamples from deep cores, Englebright Lake, California, May-June 2002—Continued.

[Analyses by U.S. Geological Survey laboratory in Boulder, Colo. First digit of sample ID and core ID represents coring site, listed in order from downstream to upstream (figure 2). mbls, meters below lake surface (spillway elevation); mblf, meters below lake floor; SD, standard deviation; Y, yes; N, no. ng/g, nanogram per gram; mm, millimeter; $\mathrm{cm}$, centimeter; <, less than]

\begin{tabular}{|c|c|c|c|c|c|c|c|c|}
\hline \multirow[b]{2}{*}{ Sample ID } & \multirow[b]{2}{*}{ Replicate } & \multirow[b]{2}{*}{ Core ID } & \multicolumn{3}{|c|}{ Relative sample location } & \multicolumn{2}{|c|}{ Total mercury } & \multirow[b]{2}{*}{$\begin{array}{l}\text { Sieved to } \\
<0.060 \mathrm{~mm}\end{array}$} \\
\hline & & & $\begin{array}{c}\text { Top } \\
\text { (mbls) }\end{array}$ & $\begin{array}{l}\text { Bottom } \\
\text { (mbls) }\end{array}$ & $\begin{array}{l}\text { Midpoint } \\
\text { (mblf) }\end{array}$ & $\begin{array}{l}\text { Concen- } \\
\text { tration } \\
\text { (ng/g, dry) }\end{array}$ & $\begin{array}{c}\text { SD } \\
\text { (ng/g, dry) }\end{array}$ & \\
\hline $7 Y-43$ & & 7C-10H-1, 10-98 cm & 37.24 & 38.06 & 23.32 & 587 & 2 & $\mathrm{Y}$ \\
\hline $7 Y-44$ & & $7 \mathrm{C}-10 \mathrm{H}-1,98-150 \mathrm{~cm}$ & 38.06 & 38.55 & 23.98 & 527 & 8 & $\mathrm{Y}$ \\
\hline $7 Y-46$ & & $7 \mathrm{C}-10 \mathrm{H}-2,67-137.5 \mathrm{~cm}$ & 39.17 & 39.87 & 25.19 & 452 & 2 & $\mathrm{Y}$ \\
\hline $7 Y-47$ & & 7B-9H-1, 57-113 cm & 39.87 & 40.41 & 25.81 & 473 & 3 & $\mathrm{Y}$ \\
\hline $7 Y-48$ & 1 of 2 & $7 \mathrm{C}-11 \mathrm{H}-1,21-70 \mathrm{~cm}$ & 40.41 & 40.88 & 26.32 & 462 & 6 & $\mathrm{Y}$ \\
\hline $7 Y-48$ & 2 of 2 & $7 \mathrm{C}-11 \mathrm{H}-1,21-70 \mathrm{~cm}$ & 40.41 & 40.88 & 26.32 & 446 & 6 & $\mathrm{Y}$ \\
\hline $7 Y-52$ & & $7 \mathrm{C}-11 \mathrm{H}-2,104-130 \mathrm{~cm}$ & 42.13 & 42.38 & 27.93 & 376 & 4 & Y \\
\hline $7 Y-53$ & & $7 \mathrm{~B}-10 \mathrm{H}-1,102-136 \mathrm{~cm}$ & 42.38 & 42.74 & 28.23 & 501 & 3 & Y \\
\hline $7 Y-54$ & & $7 \mathrm{C}-12 \mathrm{H}-1,0-47 \mathrm{~cm}$ & 42.74 & 43.21 & 28.65 & 536 & 3 & Y \\
\hline $7 Y-55$ & & $7 \mathrm{C}-12 \mathrm{H}-1,47-99.5 \mathrm{~cm}$ & 43.21 & 43.74 & 29.15 & 667 & 2 & Y \\
\hline $7 Y-56$ & & $7 \mathrm{C}-12 \mathrm{H}-1,99.5-133 \mathrm{~cm}$ & 43.74 & 44.07 & 29.58 & 602 & 3 & Y \\
\hline $7 Y-57$ & 1 of 2 & $7 \mathrm{C}-12 \mathrm{H}-2,0-40.5 \mathrm{~cm}$ & 44.07 & 44.47 & 29.94 & 332 & 2 & $\mathrm{Y}$ \\
\hline $7 Y-57$ & 2 of 2 & $7 \mathrm{C}-12 \mathrm{H}-2,0-40.5 \mathrm{~cm}$ & 44.07 & 44.47 & 29.94 & 336 & 2 & $\mathrm{Y}$ \\
\hline $7 Y-58$ & & $7 \mathrm{C}-12 \mathrm{H}-2,40.5-69 \mathrm{~cm}$ & 44.47 & 44.75 & 30.28 & 383 & 4 & $\mathrm{Y}$ \\
\hline $7 Y-61$ & & $7 \mathrm{~B}-11 \mathrm{H}-2,47-82 \mathrm{~cm}$ & 45.48 & 45.78 & 31.30 & 424 & 6 & $\mathrm{Y}$ \\
\hline $7 Y-62$ & & $7 \mathrm{~B}-11 \mathrm{H}-2,82-113 \mathrm{~cm}$ & 45.78 & 46.06 & 31.59 & 374 & 7 & $\mathrm{Y}$ \\
\hline $7 Y-63$ & & $7 \mathrm{~B}-11 \mathrm{H}-2,113-140.5 \mathrm{~cm}$ & 46.06 & 46.30 & 31.85 & 297 & 3 & $\mathrm{Y}$ \\
\hline $7 Y-64$ & & $7 \mathrm{C}-13 \mathrm{H}-3,23-55 \mathrm{~cm}$ & 46.30 & 46.52 & 32.08 & 294 & 2 & $\mathrm{Y}$ \\
\hline $7 Y-66$ & 1 of 2 & 7C-13H-3, 61.5-99 cm & 46.57 & 46.83 & 32.37 & 188 & 1 & $\mathrm{Y}$ \\
\hline $7 Y-66$ & 2 of 2 & 7C-13H-3, 61.5-99 cm & 46.57 & 46.83 & 32.37 & 194 & 2 & $\mathrm{Y}$ \\
\hline $7 Y-67$ & & $7 \mathrm{C}-13 \mathrm{H}-3,99-125.5 \mathrm{~cm}$ & 46.83 & 47.02 & 32.60 & 280 & 3 & $\mathrm{Y}$ \\
\hline $7 Y-68$ & & $7 \mathrm{C}-13 \mathrm{H}-3,125.5-142 \mathrm{~cm}$ & 47.02 & 47.13 & 32.75 & 1,365 & 37 & $\mathrm{Y}$ \\
\hline $9 \mathrm{Y}-1$ & & $9 \mathrm{~A}-1 \mathrm{H}-1,1-127 \mathrm{~cm}$ & 10.56 & 11.75 & 0.60 & 274 & 1 & $\mathrm{Y}$ \\
\hline $9 \mathrm{Y}-2$ & 1 of 2 & $9 \mathrm{~A}-1 \mathrm{H}-2,25.5-119 \mathrm{~cm}$ & 11.75 & 12.57 & 1.60 & 292 & 4 & $\mathrm{Y}$ \\
\hline $9 Y-2$ & 2 of 2 & $9 \mathrm{~A}-1 \mathrm{H}-2,25.5-119 \mathrm{~cm}$ & 11.75 & 12.57 & 1.60 & 284 & 2 & $\mathrm{Y}$ \\
\hline $9 Y-3$ & & $9 \mathrm{~A}-1 \mathrm{H}-2,119-134 \mathrm{~cm}$ & 12.57 & 12.70 & 2.08 & 317 & 2 & Y \\
\hline
\end{tabular}


Table 2. Mercury data from the Y series of subsamples from deep cores, Englebright Lake, California, May-June 2002-Continued.

[Analyses by U.S. Geological Survey laboratory in Boulder, Colo. First digit of sample ID and core ID represents coring site, listed in order from downstream to upstream (figure 2). mbls, meters below lake surface (spillway elevation); mblf, meters below lake floor; SD, standard deviation; Y, yes; N, no. ng/g, nanogram per gram; mm, millimeter; $\mathrm{cm}$, centimeter; <, less than]

\begin{tabular}{|c|c|c|c|c|c|c|c|c|}
\hline \multirow[b]{2}{*}{ Sample ID } & \multirow[b]{2}{*}{ Replicate } & \multirow[b]{2}{*}{ Core ID } & \multicolumn{3}{|c|}{ Relative sample location } & \multicolumn{2}{|c|}{ Total mercury } & \multirow[b]{2}{*}{$\begin{array}{l}\text { Sieved to } \\
<0.060 \mathrm{~mm}\end{array}$} \\
\hline & & & $\begin{array}{c}\text { Top } \\
\text { (mbls) }\end{array}$ & $\begin{array}{l}\text { Bottom } \\
\text { (mbls) }\end{array}$ & $\begin{array}{c}\text { Midpoint } \\
\text { (mblf) }\end{array}$ & $\begin{array}{l}\text { Concen- } \\
\text { tration } \\
\text { (ng/g, dry) }\end{array}$ & $\begin{array}{c}S D \\
\text { (ng/g, dry) }\end{array}$ & \\
\hline $9 Y-4$ & & $9 \mathrm{~A}-2 \mathrm{H}-1,0-24 \mathrm{~cm}$ & 13.23 & 13.43 & 2.77 & 218 & 2 & $\mathrm{Y}$ \\
\hline $9 Y-5$ & & $9 \mathrm{~A}-2 \mathrm{H}-1,24-89 \mathrm{~cm}$ & 13.43 & 13.96 & 3.14 & 290 & 3 & $\mathrm{Y}$ \\
\hline $9 Y-7$ & 1 of 2 & $9 \mathrm{C}-2 \mathrm{H}-2,0-82 \mathrm{~cm}$ & 14.35 & 15.15 & 4.19 & 211 & 1 & $\mathrm{Y}$ \\
\hline $9 Y-7$ & 2 of 2 & $9 \mathrm{C}-2 \mathrm{H}-2,0-82 \mathrm{~cm}$ & 14.35 & 15.15 & 4.19 & 241 & 0 & $\mathrm{Y}$ \\
\hline $9 Y-8$ & 1 of 2 & $9 \mathrm{~A}-2 \mathrm{H}-3,56-108.5 \mathrm{~cm}$ & 15.15 & 15.70 & 4.87 & 283 & 1 & $\mathrm{Y}$ \\
\hline $9 Y-8$ & 2 of 2 & $9 \mathrm{~A}-2 \mathrm{H}-3,56-108.5 \mathrm{~cm}$ & 15.15 & 15.70 & 4.87 & 258 & 3 & $\mathrm{Y}$ \\
\hline $9 Y-12$ & & $9 \mathrm{~A}-3 \mathrm{H}-2,0-44.5 \mathrm{~cm}$ & 17.07 & 17.55 & 6.75 & 129 & 0 & $\mathrm{Y}$ \\
\hline $9 Y-13$ & 1 of 2 & $9 \mathrm{~A}-3 \mathrm{H}-2,44.5-82 \mathrm{~cm}$ & 17.55 & 17.95 & 7.19 & 145 & 1 & $\mathrm{Y}$ \\
\hline $9 Y-13$ & 2 of 2 & $9 \mathrm{~A}-3 \mathrm{H}-2,44.5-82 \mathrm{~cm}$ & 17.55 & 17.95 & 7.19 & 106 & 0 & $\mathrm{Y}$ \\
\hline $9 Y-14$ & & $9 \mathrm{~A}-3 \mathrm{H}-2,82-150 \mathrm{~cm}$ & 17.95 & 18.69 & 7.76 & 222 & 5 & $\mathrm{Y}$ \\
\hline $9 Y-15$ & & $9 \mathrm{C}-4 \mathrm{H}-1,0-97 \mathrm{~cm}$ & 18.69 & 19.64 & 8.61 & 142 & 1 & $\mathrm{Y}$ \\
\hline $9 Y-16$ & & $9 \mathrm{C}-4 \mathrm{H}-2,9-48 \mathrm{~cm}$ & 19.64 & 20.03 & 9.28 & 227 & 2 & $\mathrm{Y}$ \\
\hline $9 Y-17$ & 1 of 2 & $9 \mathrm{C}-4 \mathrm{H}-2,48-131.5 \mathrm{~cm}$ & 20.03 & 20.86 & 9.89 & 225 & 7 & $\mathrm{Y}$ \\
\hline $9 Y-17$ & 2 of 2 & $9 \mathrm{C}-4 \mathrm{H}-2,48-131.5 \mathrm{~cm}$ & 20.03 & 20.86 & 9.89 & 263 & 2 & $\mathrm{Y}$ \\
\hline $9 Y-23$ & & $9 \mathrm{~A}-8 \mathrm{H}-2,31-129 \mathrm{~cm}$ & 25.14 & 25.99 & 15.01 & 466 & 5 & $\mathrm{Y}$ \\
\hline $9 Y-24$ & & $9 \mathrm{C}-7 \mathrm{H}-1,21-89 \mathrm{~cm}$ & 25.99 & 26.66 & 15.77 & 422 & 3 & $\mathrm{Y}$ \\
\hline $9 Y-25$ & & $9 \mathrm{C}-7 \mathrm{H}-1,89-148 \mathrm{~cm}$ & 26.66 & 27.25 & 16.40 & 430 & 4 & $\mathrm{Y}$ \\
\hline $9 Y-26$ & & $9 \mathrm{C}-7 \mathrm{H}-2,0-60.5 \mathrm{~cm}$ & 27.25 & 27.85 & 16.99 & 377 & 2 & $\mathrm{Y}$ \\
\hline $9 Y-27$ & 1 of 2 & $9 \mathrm{C}-7 \mathrm{H}-2,60.5-140 \mathrm{~cm}$ & 27.85 & 28.64 & 17.69 & 444 & 2 & $\mathrm{Y}$ \\
\hline $9 Y-27$ & 2 of 2 & $9 \mathrm{C}-7 \mathrm{H}-2,60.5-140 \mathrm{~cm}$ & 27.85 & 28.64 & 17.69 & 348 & 2 & $\mathrm{Y}$ \\
\hline $9 Y-28$ & 1 of 2 & $9 \mathrm{C}-8 \mathrm{H}-1,0-84 \mathrm{~cm}$ & 28.74 & 29.52 & 18.57 & 376 & 2 & $\mathrm{Y}$ \\
\hline $9 Y-28$ & 2 of 2 & $9 \mathrm{C}-8 \mathrm{H}-1,0-84 \mathrm{~cm}$ & 28.74 & 29.52 & 18.57 & 491 & 7 & $\mathrm{Y}$ \\
\hline $9 Y-29$ & & $9 \mathrm{C}-8 \mathrm{H}-1,84-150 \mathrm{~cm}$ & 29.52 & 30.14 & 19.27 & 227 & 1 & $\mathrm{Y}$ \\
\hline $9 Y-30$ & & $9 \mathrm{C}-8 \mathrm{H}-4,0-38 \mathrm{~cm}$ & 30.16 & 30.53 & 19.79 & 577 & 8 & $\mathrm{Y}$ \\
\hline $9 Y-31$ & & $9 \mathrm{C}-8 \mathrm{H}-4,38-82.5 \mathrm{~cm}$ & 30.53 & 30.97 & 20.19 & 342 & 3 & $\mathrm{Y}$ \\
\hline $9 Y-32$ & & $9 \mathrm{C}-8 \mathrm{H}-4,82.5-125.5 \mathrm{~cm}$ & 30.97 & 31.40 & 20.63 & 501 & 0 & $\mathrm{Y}$ \\
\hline
\end{tabular}


Table 2. Mercury data from the Y series of subsamples from deep cores, Englebright Lake, California, May-June 2002—Continued.

[Analyses by U.S. Geological Survey laboratory in Boulder, Colo. First digit of sample ID and core ID represents coring site, listed in order from downstream to upstream (figure 2). mbls, meters below lake surface (spillway elevation); mblf, meters below lake floor; SD, standard deviation; Y, yes; N, no. ng/g, nanogram per gram; mm, millimeter; $\mathrm{cm}$, centimeter; <, less than]

\begin{tabular}{|c|c|c|c|c|c|c|c|c|}
\hline Sample ID & Replicate & Core ID & \multicolumn{3}{|c|}{ Relative sample location } & \multicolumn{2}{|c|}{ Total mercury } & $\begin{array}{l}\text { Sieved to } \\
<0.060 \mathrm{~mm}\end{array}$ \\
\hline $9 Y-33$ & & $9 \mathrm{~A}-10 \mathrm{H}-3,0-35 \mathrm{~cm}$ & 31.40 & 31.71 & 21.00 & 186 & 5 & $\mathrm{Y}$ \\
\hline $9 Y-34$ & & $9 \mathrm{~A}-10 \mathrm{H}-3,35-94.5 \mathrm{~cm}$ & 31.71 & 32.26 & 21.43 & 232 & 2 & $\mathrm{Y}$ \\
\hline $9 Y-35$ & 2 of 2 & $9 \mathrm{~A}-10 \mathrm{H}-3,94.5-135.5 \mathrm{~cm}$ & 32.26 & 32.63 & 21.89 & 184 & 3 & $\mathrm{Y}$ \\
\hline $9 Y-36$ & & $9 \mathrm{C}-9 \mathrm{H}-3,7-41 \mathrm{~cm}$ & 32.63 & 32.95 & 22.23 & 346 & 2 & $\mathrm{Y}$ \\
\hline $9 Y-37$ & 1 of 2 & 9C-9H-3, 41-99 cm & 32.95 & 33.50 & 22.67 & 151 & 3 & $\mathrm{Y}$ \\
\hline $9 Y-37$ & 2 of 2 & 9C-9H-3, 41-99 cm & 32.95 & 33.50 & 22.67 & 153 & 1 & $\mathrm{Y}$ \\
\hline $8 \mathrm{Y}-2$ & & $8 \mathrm{~A}-1 \mathrm{H}-2,0-17 \mathrm{~cm}$ & 10.20 & 10.37 & 0.13 & 208 & 6.3 & Y \\
\hline $8 Y-3$ & & $8 \mathrm{~A}-1 \mathrm{H}-2,17-45.5 \mathrm{~cm}$ & 10.37 & 10.66 & 0.36 & 298 & 4 & $\mathrm{Y}$ \\
\hline $8 Y-4$ & & $8 \mathrm{~A}-1 \mathrm{H}-2,45.5-89 \mathrm{~cm}$ & 10.66 & 11.09 & 0.72 & 127 & 2 & $\mathrm{Y}$ \\
\hline $8 Y-5$ & & $8 \mathrm{~A}-1 \mathrm{H}-3,0-127.5 \mathrm{~cm}$ & 11.09 & 12.37 & 1.57 & 223 & 5 & $\mathrm{Y}$ \\
\hline $8 Y-6$ & 1 of 2 & $8 \mathrm{~A}-1 \mathrm{H}-3,127.5-150 \mathrm{~cm}$ & 12.37 & 12.59 & 2.32 & 247 & 3 & $\mathrm{Y}$ \\
\hline $8 Y-6$ & 2 of 2 & $8 \mathrm{~A}-1 \mathrm{H}-3,127.5-150 \mathrm{~cm}$ & 12.37 & 12.59 & 2.32 & 263 & 3 & $\mathrm{Y}$ \\
\hline $8 \mathrm{Y}-7$ & & $8 \mathrm{~A}-1 \mathrm{H}-6,0-5 \mathrm{~cm}$ & 12.59 & 12.64 & 2.46 & 269 & 2 & $\mathrm{Y}$ \\
\hline $8 Y-43 X$ & & $8 \mathrm{~B}-1 \mathrm{H}-2,43-101 \mathrm{~cm}$ & 12.64 & 13.02 & 2.67 & 160 & 5.8 & $\mathrm{Y}$ \\
\hline $8 Y-13$ & & $8 \mathrm{~B}-2 \mathrm{H}-1,62-127 \mathrm{~cm}$ & 14.83 & 15.47 & 4.99 & 266 & 8 & $\mathrm{Y}$ \\
\hline $8 Y-14$ & & $8 \mathrm{~B}-2 \mathrm{H}-2,5-133 \mathrm{~cm}$ & 15.47 & 16.75 & 5.95 & 220 & 4 & $\mathrm{Y}$ \\
\hline $8 Y-15$ & & $8 \mathrm{~A}-4 \mathrm{H}-2,3-82 \mathrm{~cm}$ & 16.81 & 17.60 & 7.05 & 152 & 2 & $\mathrm{Y}$ \\
\hline $8 Y-16$ & & $8 \mathrm{~B}-3 \mathrm{H}-1,16-83 \mathrm{~cm}$ & 17.60 & 18.27 & 7.78 & 236 & 2 & $\mathrm{Y}$ \\
\hline $8 Y-17$ & 1 of 2 & $8 \mathrm{~B}-3 \mathrm{H}-2,0-136 \mathrm{~cm}$ & 18.27 & 19.63 & 8.79 & 232 & 0 & $\mathrm{Y}$ \\
\hline $8 Y-17$ & 2 of 2 & $8 \mathrm{~B}-3 \mathrm{H}-2,0-136 \mathrm{~cm}$ & 18.27 & 19.63 & 8.79 & 221 & 4 & $\mathrm{Y}$ \\
\hline $8 Y-18$ & & $8 \mathrm{C}-2 \mathrm{H}-1,17-81 \mathrm{~cm}$ & 19.63 & 20.23 & 9.77 & 641 & 9 & $\mathrm{Y}$ \\
\hline $8 Y-19$ & & $8 \mathrm{C}-2 \mathrm{H}-1,81-133 \mathrm{~cm}$ & 20.23 & 20.72 & 10.32 & 1,020 & 17 & $\mathrm{Y}$ \\
\hline $8 Y-20$ & & $8 \mathrm{C}-2 \mathrm{H}-2,0-31 \mathrm{~cm}$ & 20.72 & 20.99 & 10.70 & 508 & 2 & Y \\
\hline $8 Y-21$ & & $8 \mathrm{C}-2 \mathrm{H}-2,31-102 \mathrm{~cm}$ & 20.99 & 21.59 & 11.13 & 381 & 9 & $\mathrm{Y}$ \\
\hline $8 Y-22$ & & $8 \mathrm{~A}-8 \mathrm{H}-1,29-129 \mathrm{~cm}$ & 21.59 & 22.59 & 11.93 & 284 & 8 & Y \\
\hline $8 Y-23$ & & $8 \mathrm{C}-3 \mathrm{H}-1,33-66 \mathrm{~cm}$ & 22.59 & 22.74 & 12.51 & 183 & 10 & $\mathrm{Y}$ \\
\hline
\end{tabular}


Table 2. Mercury data from the $\mathrm{Y}$ series of subsamples from deep cores, Englebright Lake, California, May-June 2002—Continued.

[Analyses by U.S. Geological Survey laboratory in Boulder, Colo. First digit of sample ID and core ID represents coring site, listed in order from downstream to upstream (figure 2). mbls, meters below lake surface (spillway elevation); mblf, meters below lake floor; SD, standard deviation; Y, yes; N, no. ng/g, nanogram per gram; mm, millimeter; $\mathrm{cm}$, centimeter; <, less than]

\begin{tabular}{|c|c|c|c|c|c|c|c|c|}
\hline \multirow[b]{2}{*}{ Sample ID } & \multirow[b]{2}{*}{ Replicate } & \multirow[b]{2}{*}{ Core ID } & \multicolumn{3}{|c|}{ Relative sample location } & \multicolumn{2}{|c|}{ Total mercury } & \multirow[b]{2}{*}{$\begin{array}{c}\text { Sieved to } \\
<0.060 \mathrm{~mm}\end{array}$} \\
\hline & & & $\begin{array}{c}\text { Top } \\
\text { (mbls) }\end{array}$ & $\begin{array}{l}\text { Bottom } \\
\text { (mbls) }\end{array}$ & $\begin{array}{c}\text { Midpoint } \\
\text { (mblf) }\end{array}$ & $\begin{array}{c}\text { Concen- } \\
\text { tration } \\
\text { (ng/g, dry) }\end{array}$ & $\underset{(\mathbf{n g} / \mathbf{g}, \text { dry) }}{\text { SD }}$ & \\
\hline $8 \mathrm{Y}-24$ & & $8 \mathrm{C}-3 \mathrm{H}-1,66-102 \mathrm{~cm}$ & 22.74 & 22.91 & 12.67 & 243 & 2 & Y \\
\hline $8 \mathrm{Y}-25$ & & $8 \mathrm{C}-3 \mathrm{H}-2,0-73 \mathrm{~cm}$ & 22.91 & 23.27 & 12.93 & 282 & 1 & $\mathrm{Y}$ \\
\hline $8 \mathrm{Y}-26$ & & $8 \mathrm{C}-3 \mathrm{H}-2,73-135 \mathrm{~cm}$ & 23.27 & 23.57 & 13.26 & 320 & 2 & $\mathrm{Y}$ \\
\hline $8 Y-27$ & & $8 \mathrm{~A}-10 \mathrm{H}-1,42.5-76.5 \mathrm{~cm}$ & 23.57 & 23.91 & 13.58 & 293 & 11 & Y \\
\hline $8 Y-28$ & & $8 \mathrm{~A}-10 \mathrm{H}-1,76.5-110 \mathrm{~cm}$ & 23.91 & 24.24 & 13.92 & 280 & 3 & Y \\
\hline $8 Y-29$ & & $8 \mathrm{C}-4 \mathrm{H}-1,22-141 \mathrm{~cm}$ & 24.24 & 25.57 & 14.75 & 248 & 0 & Y \\
\hline $8 \mathrm{Y}-30$ & & $8 \mathrm{C}-4 \mathrm{H}-2,0-26 \mathrm{~cm}$ & 25.57 & 25.84 & 15.55 & 180 & 8 & Y \\
\hline $8 Y-31$ & 1 of 2 & $8 \mathrm{C}-4 \mathrm{H}-2,26-151 \mathrm{~cm}$ & 25.84 & 27.15 & 16.34 & 290 & 8 & Y \\
\hline $8 Y-31$ & 2 of 2 & $8 \mathrm{C}-4 \mathrm{H}-2,26-151 \mathrm{~cm}$ & 25.84 & 27.15 & 16.34 & 302 & 2 & Y \\
\hline $8 \mathrm{Y}-32$ & & $8 \mathrm{~A}-12 \mathrm{H}-1,113.5-142 \mathrm{~cm}$ & 27.15 & 27.43 & 17.13 & 223 & 4 & Y \\
\hline $8 Y-33$ & & $8 \mathrm{C}-5 \mathrm{H}-1,34.5-136 \mathrm{~cm}$ & 27.43 & 28.18 & 17.65 & 262 & 6 & Y \\
\hline $8 \mathrm{Y}-34$ & 1 of 2 & $8 \mathrm{C}-5 \mathrm{H}-2,0-59.5 \mathrm{~cm}$ & 28.18 & 28.63 & 18.25 & 207 & 8 & Y \\
\hline $8 \mathrm{Y}-34$ & 2 of 2 & $8 \mathrm{C}-5 \mathrm{H}-2,0-59.5 \mathrm{~cm}$ & 28.18 & 28.63 & 18.25 & 193 & 6 & Y \\
\hline $8 \mathrm{Y}-35$ & & $8 \mathrm{C}-5 \mathrm{H}-2,0-59.5 \mathrm{~cm}$ & 28.63 & 29.07 & 18.69 & 213 & 3 & Y \\
\hline $8 \mathrm{Y}-36$ & & $8 \mathrm{~A}-13 \mathrm{H}-1,25-144 \mathrm{~cm}$ & 29.07 & 30.26 & 19.51 & 214 & 2 & Y \\
\hline $8 \mathrm{Y}-37$ & & $8 \mathrm{~A}, 13 \mathrm{H}-2,0-50.5 \mathrm{~cm}$ & 30.26 & 30.76 & 20.35 & 120 & 5 & Y \\
\hline $8 \mathrm{Y}-38$ & & $8 \mathrm{~A}-13 \mathrm{H}-2,50.5-126 \mathrm{~cm}$ & 30.76 & 31.50 & 20.97 & 258 & 2 & Y \\
\hline $8 Y-39$ & & $8 \mathrm{C}-6 \mathrm{H}-3,65.5-125 \mathrm{~cm}$ & 31.50 & 32.02 & 21.60 & 115 & 4 & Y \\
\hline $8 \mathrm{Y}-40$ & & $8 \mathrm{~A}-14 \mathrm{H}-1,16-81 \mathrm{~cm}$ & 32.02 & 32.67 & 22.19 & 147 & 5 & Y \\
\hline $8 \mathrm{Y}-41$ & & $8 \mathrm{~A}-14 \mathrm{H}-2,0-21.5 \mathrm{~cm}$ & 32.67 & 32.89 & 22.62 & 1,568 & 47 & Y \\
\hline $8 \mathrm{Y}-42$ & & $8 \mathrm{~A}-14 \mathrm{H}-2,21.5-115 \mathrm{~cm}$ & 32.89 & 33.82 & 23.20 & 1,239 & 3.9 & $\mathrm{Y}$ \\
\hline
\end{tabular}

Other quality-assurance procedures used by the BMSL in conjunction with its $\mathrm{MeHg}$ determinations included analyses of blanks and spike additions. Three analytical blanks were analyzed with each analytical batch of samples. $\mathrm{MeHg}$ was detected in 13 of the 57 blanks at concentrations less than $0.028 \mathrm{ng} / \mathrm{g}$ (four times the MDL of $0.007 \mathrm{ng} / \mathrm{g}$, dry basis); the median blank value was less than the MDL, so the reported data were not blank-corrected. Recalculating the results after blank correction would result in an average change of less than 2 percent. Four of the 166 subsamples in the MEM series had $\mathrm{MeHg}$ results less than the MDL, and about 10 percent of all MeHg analyses (including the MEM series and the shallow box cores) had reported values less than five times the MDL. Thirty-four pairs of MeHg matrix spikes and matrix spike replicates were analyzed with the samples. Recoveries ranged from 70 to 130 percent, within the laboratory's data-quality objectives ( 65 to 135 percent recovery). The RPD between the matrix spikes and the matrix spike replicates ranged from 1 to 35 percent for $\mathrm{MeHg}$, within the BMSL's data-quality objectives.

Deep cores were refrigerated at approximately $4^{\circ} \mathrm{C}$ between collection and splitting; the MEM subsamples used for analysis of $\mathrm{MeHg}$ were frozen immediately after splitting. Shallow cores were processed immediately after collection and subsamples for analysis of $\mathrm{MeHg}$ were immediately frozen. Elapsed time between coring and analysis of $\mathrm{MeHg}$ by the BMSL ranged from 9 to 10 months for shallow cores and 14 to 16 months for deep cores. Despite careful handling, it is possible that $\mathrm{MeHg}$ concentration changed during sample storage, particularly when the deep cores were stored at $4{ }^{\circ} \mathrm{C}$ rather than frozen, because of microbiological activity. However, it is not known whether $\mathrm{MeHg}$ may have increased or decreased during chilled or frozen storage, because changes in either direction have been observed in samples from other studies (Eric von 
der Geest, Moss Landing Marine Laboratories, California, oral commun., 2005).

As an additional check on the quality of $\mathrm{MeHg}$ analyses, 15 subsamples from the MEM series (deep cores) were split evenly and analyzed by both the BMSL and the USGSWDML (table A5). Three of the 15 subsamples had $\mathrm{MeHg}$ concentrations below the detection limit of the WDML, which ranged from 0.094 to $0.13 \mathrm{ng} / \mathrm{g}$. The BMSL had a lower detection limit $(0.007 \mathrm{ng} / \mathrm{g})$, and it reported $\mathrm{MeHg}$ concentrations for these three subsamples that were consistent with the WDML results. No values of RPD were computed for these three subsamples. The median of the RPD values for $\mathrm{MeHg}$ analyses in the 12 other split subsamples was 27.7 percent. All 12 of the concentration values reported by the BMSL were higher than the corresponding values reported by the WDML, indicating a consistent bias. The ratio of the $\mathrm{MeHg}$ concentrations reported by the two laboratories (WDML:BSML) ranged from 60 to 92 percent (table A5); the mean and the median values for RPD for the 12 subsamples were 76 percent. A linear least-squares regression for these 12 data points indicates a slope of 0.79 and an $\mathrm{R}^{2}$ value of 0.994 . A plot of the splitsample data

(fig. A2) shows the line of perfect agreement (labeled 100 percent) and a line corresponding to a ratio of 79 percent that represents a reasonable fit to the data.

The WDML analyzed SRMs IAEA-356 and IAEA-405 also for $\mathrm{MeHg}$; overall results were similar to those produced by the BMSL (table A3). The average recoveries for the SRMs by the WDML were 92 percent (IAEA-356) and 72 percent (IAEA-405), averaging 82 percent; the average SRM recoveries by the BMSL were 74 percent (IAEA-356) and 84 percent (IAEA-405), averaging 79 percent. These results suggest that laboratory accuracy was not the primary cause of the differences between results for the 15 split subsamples by the two laboratories.

Differences in handling and frozen storage time of the split subsamples analyzed by the two laboratories are possible factors in the differences between the results. The split subsamples were analyzed for $\mathrm{MeHg}$ by the BMSL during July-September 2003 and by the WDML during March-April 2005, about 18-21 months later. Another difference in handling samples was that the split subsamples analyzed by the WDML were thawed for a short period (1-2 hours) in August 2004 and then refrozen, whereas the split subsamples analyzed by the BMSL were frozen continuously. Thus it is possible that some $\mathrm{MeHg}$ degraded during the extended frozen storage time or the brief additional thawed period, resulting in the lower concentrations measured by the WDML.

Because each laboratory analyzed $\mathrm{MeHg}$ in sediment during a relatively narrow time frame, the overall findings of this study relating to the spatial variability of $\mathrm{MeHg}$ concentration are not affected by the results of the interlaboratory splitsample comparison or possible sample storage effects. Even if $\mathrm{MeHg}$ in the subsamples degraded partially during frozen storage, the extent of degradation would have been similar for all subsamples analyzed by each laboratory. Thus, the overall findings of this study relating to the spatial variability of $\mathrm{MeHg}$ concentration and of the ratio of $\mathrm{MeHg}$ to $\mathrm{Hg}_{\mathrm{T}}$ would not be affected.

\section{Trace and Major Elements}

The SRM used for trace and major elements by the USGS laboratory in Boulder, Colorado, was Buffalo River Sediment (NIST 2704; National Institute of Standards and Technology, 1990). Results of 22 analyses of NIST 2704 (table B1) using digestion and analysis procedures identical to those used for the environmental samples indicate a wide range of behavior for different groups of elements. For several trace elements, the SRM results are very close to the certified value (recovery values computed by dividing the overall average values by the certified value, in percent): antimony (101), arsenic (91), cadmium (99), chromium (92), copper (98), lead (100), nickel (95), and zinc (95). For several major elements, the SRM results were consistently lower than the certified values: aluminum (59), barium (74), calcium (73), magnesium (46), and potassium (80). This indicates that the acid digestion procedure used for this study did not result in complete recoveries of these major elements, but did result in more complete recoveries of most trace elements, including transition metals and the semi-metals antimony and arsenic.

Digestion blanks were analyzed as part of each batch of environmental samples, a total of 16 (table B2). Concentrations measured in these blanks were generally near the detection limit for most trace metals, much lower than the values for environmental samples, so the data did not need to be blank-corrected. Blank spikes were prepared for seven selected elements (arsenic, cadmium, calcium, copper, lead, magnesium, and zinc) on six occasions (table B3). Recoveries from blank spikes were within an acceptable range (85 to 115 percent of expected concentration) for all analyses except one of the analyses for arsenic.

Replicate digestions were made of 29 subsamples, which were analyzed for 53 trace and major elements (table B4). For several trace elements of interest, median values of RPD were less than or equal to 5 percent, indicating a high degree of reproducibility; median RPD values (in percent) include arsenic (3), antimony (4), copper (5), lead (1.5), nickel (3), and zinc (4). For major elements, median RPD values for replicate subsamples were typically in the range of 9 to 15 percent: aluminum (15), barium (12), calcium (9), magnesium (15), potassium (9), and sodium (6). The digestate from each replicate subsample was analyzed in triplicate. Standard deviations reported in tables $B 4$ (replicate subsamples) and B5 (all subsamples) indicate analytical variability (precision). For concentrations greater than 10 times the MDL, standard deviation values for trace metals were generally less than 20 percent of the average amount present. For concentrations closer to the MDL, standard deviation values tend to represent a higher proportion of the amount present (Alpers and others, 2000). 


\section{Results}

\section{Total Mercury and Methylmercury}

Concentration data for total mercury $\left(\mathrm{Hg}_{\mathrm{T}}\right)$ and methylmercury $(\mathrm{MeHg})$ in subsamples from shallow and deep cores are presented in this section. Data for grain-size distribution and loss on ignition for these subsamples were reported by Snyder and others (2004b). The Y-series subsamples were analyzed for trace and major elements, as discussed in a later section. Data for $\mathrm{Hg}_{\mathrm{T}}$ are given in tables 2 and 3 (Y-series and MEM-series) for the deep cores and in table 4 for the shallow cores. Data for $\mathrm{MeHg}$ are given in table 3 (MEM-series) and table 4 (shallow cores). The distribution of compositions with depth for $\mathrm{Hg}_{\mathrm{T}}$ and selected trace elements in Y-series subsamples is shown on figures 4-8. Data for $\mathrm{Hg}_{\mathrm{T}}, \mathrm{MeHg}$, and the ratio of $\mathrm{MeHg}$ to $\mathrm{Hg}_{\mathrm{T}}$ for the MEM-series are plotted with respect to depth in figure 9. Some statistics regarding the spatial variation (longitudinal and vertical) of $\mathrm{Hg}_{\mathrm{T}}, \mathrm{MeHg}$, and the ratio of $\mathrm{Hg}_{\mathrm{T}}$ to $\mathrm{MeHg}$ are summarized in tables 5 and 6. Summary statistics regarding the longitudinal variation of selected trace elements are given in table 7. A quantitative statistical analysis of the relations between grain-size distribution and concentrations of $\mathrm{Hg}_{\mathrm{T}}, \mathrm{MeHg}$, loss on ignition, and other sediment properties, and trends of $\mathrm{Hg}$ concentration with time in the context of the sedimentation history of the reservoir will be published separately.

The Y-series of subsamples from the deep cores best represent the spatial distribution of $\mathrm{Hg}_{\mathrm{T}}$ in Englebright Lake sediments. The Y-series represents a continuous vertical profile of the sediment deposit at several locations, taking advantage of multiple adjacent drill holes to avoid gaps in the profile between core sections. A total of 202 Y-series subsamples from five deep coring locations were analyzed for total mercury (table 2); in upstream order, starting near Englebright Dam, the sites are 1, 4, 7, 9, and 8 (fig. 2). Plots of $\mathrm{Hg}_{\mathrm{T}}$ versus depth for the Y-series subsamples are shown in box A of figures 4-8. Note that the Y-series subsamples from site 4 were not screened prior to analysis, whereas the subsamples from the other four sites were screened at $0.060 \mathrm{~mm}$ and only the fines fraction (silt- and clay-size particles) was analyzed. In general, the fine-grained fraction of sediment tends to have higher concentrations of trace metals, including mercury and methylmercury, because of the association of the trace metals with fine-grained particles containing hydrous ferric oxides, clay minerals, and organic material (Horowitz, 1991; Hunerlach and others, 2004). Lines on the plots in figures 4-8 represent vertical trends of concentration values; the lines pass through the average of the depth interval values for the replicate subsamples.
The MEM-series of subsamples, also from the deep cores, provided a linkage between analyses of $\mathrm{Hg}_{\mathrm{T}}$ and $\mathrm{MeHg}$. These subsamples are discrete subsamples of a more limited vertical extent (typically about $10-15 \mathrm{~cm}$ ) compared with the continuous, Y-series subsamples (typically 25 to $100 \mathrm{~cm}$; Snyder and others, 2004a). The MEM-series subsamples were analyzed for $\mathrm{Hg}_{\mathrm{T}}$ and $\mathrm{MeHg}$ by the BMSL (table 3). The MEM-series subsamples were also analyzed for grain-size distribution (fig. 9) and loss on ignition (Snyder and others, 2004b), but were not analyzed for trace or major elements. All seven of the deep coring sites were sampled in the MEMseries; in upstream order, these sites are 1, 6, 4, 7, 9, 8, and 2 (fig. 2). Plots of $\mathrm{Hg}_{\mathrm{T}}$ and $\mathrm{MeHg}$ versus depth for the MEMseries subsamples are shown in figures $9 A$ and $9 B$. A plot of the ratio $\mathrm{MeHg} / \mathrm{Hg}_{\mathrm{T}}$ versus depth is shown in figure $9 C$, and the relation between median grain size and depth is shown in figure 9D.

At the deep coring sites closest to Englebright Dam (sites 1,6 , and 4), concentrations of $\mathrm{Hg}_{\mathrm{T}}$ in subsamples from both the Y-series (sites 1 and 4; figs. 4A, 5A) and the MEM-series (sites 1,6 , and 4 ; fig. 9A) were generally 100 to $500 \mathrm{ng} / \mathrm{g}$ (nanograms per gram). The median grain size at these sites (figs. $4 H, 5 H)$ was consistently silt-sized ( 0.004 to $0.063 \mathrm{~mm}$ ) (figs. $4 H, 5 H, 9 D)$. At the more upstream deep coring sites ( 7 , 9, 8, and 2), unsieved MEM-series subsamples from the upper parts of the profile have lower concentrations of $\mathrm{Hg}_{\mathrm{T}}$, generally from 2 to $100 \mathrm{ng} / \mathrm{g}$, and typically coarser grain size, with median grain size in the sand range $(0.063$ to $2.0 \mathrm{~mm}$; fig. $9 D)$. In contrast, the MEM-series subsamples from the lower parts of these profiles have median grain size in the fine sand and silt range (about 0.007 to $0.3 \mathrm{~mm}$; fig. $9 D$ ) and higher concentrations of $\mathrm{Hg}_{\mathrm{T}}$ (fig. 9A).

The fines fraction from the upper parts of the upstream coring site profiles (Y-series subsamples, sites 7, 9, and 8) had concentrations of $\mathrm{Hg}_{\mathrm{T}}$ in most subsamples ranging from about 100 to $300 \mathrm{ng} / \mathrm{g}$ (figs. 6A, 7A, and 8A). In the fines fraction from the sieved Y-series subsamples at sites 7 and 9 (figs. $6 A$ and $7 \mathrm{~A}$ ) concentrations of $\mathrm{Hg}_{\mathrm{T}}$ in the lower parts of the profile were generally higher (most subsamples 200 to $600 \mathrm{ng} / \mathrm{g}$ ) than those in the upper parts of the same profiles. At site 8 (fig. $8 A$ ), the $\mathrm{Hg}_{\mathrm{T}}$ concentration of the fines fraction ranged from 100 to $300 \mathrm{ng} / \mathrm{g}$ for most subsamples; four intervals in the middle of the profile had concentrations from about 300 to $1,000 \mathrm{ng} / \mathrm{g}$.

The highest concentrations of $\mathrm{Hg}_{\mathrm{T}}$ in the fines fraction of sieved subsamples (Y-series) were found in the bottom interval at site 7 (fig. $6 \mathrm{~A}$ ) and the bottom two intervals at site 8 (fig. 8A). In these three subsamples, concentrations of $\mathrm{Hg}_{\mathrm{T}}$ ranged from about 1,200 to $1,600 \mathrm{ng} / \mathrm{g}$. Other trace elements, including arsenic, lead, and antimony, were also elevated in these subsamples, as discussed below. 
Table 3. Mercury and methylmercury data from the MEM series of subsamples from deep cores, Englebright Lake, California, May-June 2002.

[Analyses by Battelle Marine Sciences Laboratory, Sequim, Wash. mbls, meters below lake surface (spillway elevation); mblf, meters below lake floor; $\mathrm{Hg}_{\mathrm{T}}$, total mercury; MeHg, methylmercury; ng/g, nanogram per gram; \%, percentage; —, not determined; <, less than]

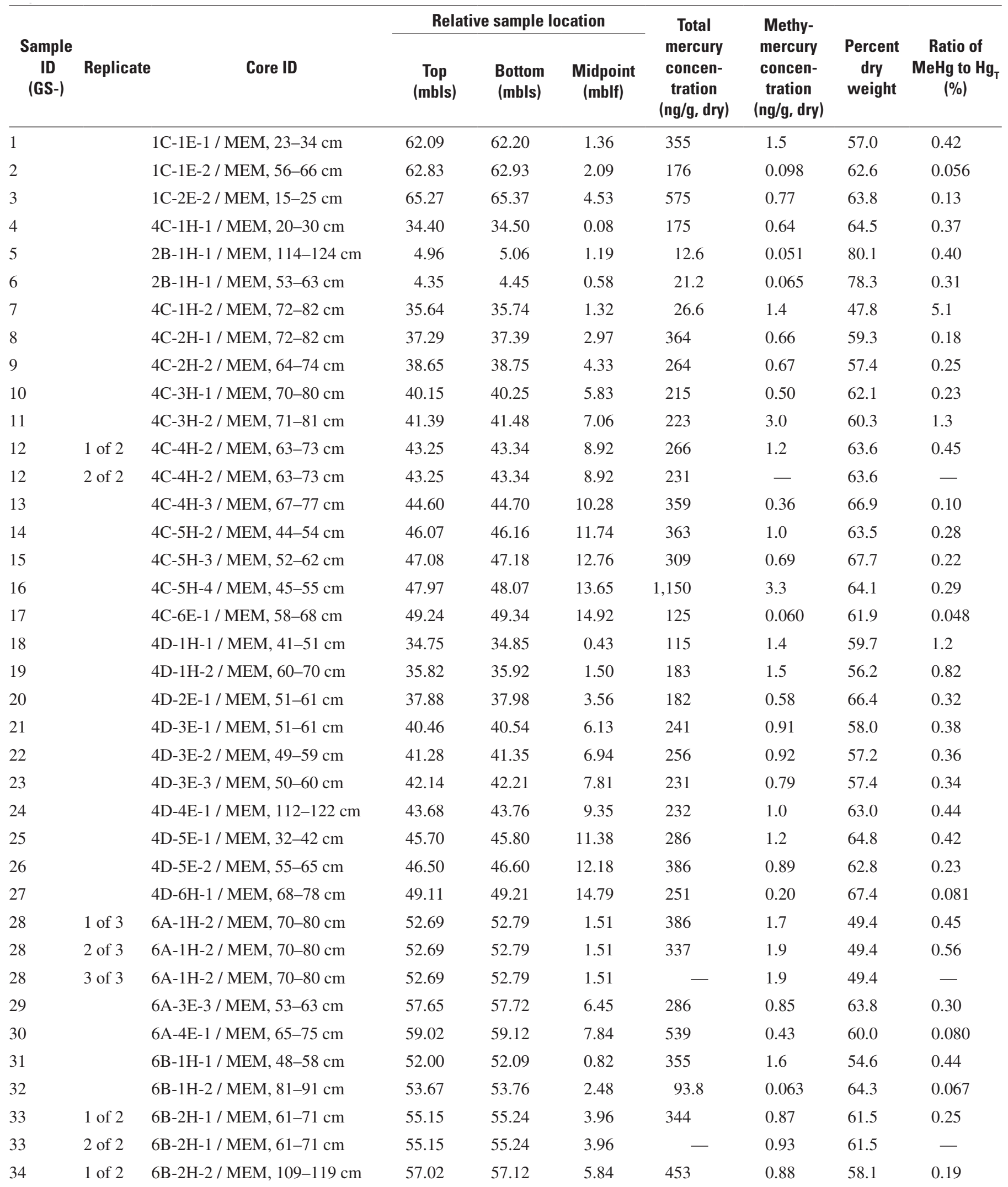


Table 3. Mercury and methylmercury data from the MEM series of subsamples from deep cores, Englebright Lake, California, May-June 2002-Continued.

[Analyses by Battelle Marine Sciences Laboratory, Sequim, Wash. mbls, meters below lake surface (spillway elevation); mblf, meters below lake floor; $\mathrm{Hg}_{\mathrm{T}}$, total mercury; MeHg, methylmercury; ng/g, nanogram per gram; \%, percentage; —, not determined; <, less than]

\begin{tabular}{|c|c|c|c|c|c|c|c|c|c|}
\hline \multirow{2}{*}{$\begin{array}{c}\text { Sample } \\
\text { ID } \\
\text { (GS-) }\end{array}$} & \multirow[b]{2}{*}{ Replicate } & \multirow[b]{2}{*}{ Core ID } & \multicolumn{3}{|c|}{ Relative sample location } & \multirow{2}{*}{$\begin{array}{c}\text { Total } \\
\text { mercury } \\
\text { concen- } \\
\text { tration } \\
\text { (ng/g, dry) }\end{array}$} & \multirow{2}{*}{$\begin{array}{l}\text { Methy- } \\
\text { mercury } \\
\text { concen- } \\
\text { tration } \\
\text { (ng/g, dry) }\end{array}$} & \multirow{2}{*}{$\begin{array}{c}\text { Percent } \\
\text { dry } \\
\text { weight }\end{array}$} & \multirow{2}{*}{$\begin{array}{c}\text { Ratio of } \\
\text { MeHg to } \mathrm{Hg}_{\mathrm{T}} \\
(\%)\end{array}$} \\
\hline & & & $\begin{array}{c}\text { Top } \\
\text { (mbls) }\end{array}$ & $\begin{array}{c}\text { Bottom } \\
\text { (mbls) }\end{array}$ & $\begin{array}{c}\text { Midpoint } \\
\text { (mblf) }\end{array}$ & & & & \\
\hline 34 & 2 of 2 & 6B-2H-2 / MEM, 109-119 cm & 57.02 & 57.12 & 5.84 & 471 & - & 58.1 & - \\
\hline 35 & & 6A-3E-1 / MEM, 62-72 cm & 56.79 & 56.86 & 5.60 & 259 & 0.57 & 64.3 & 0.22 \\
\hline 37 & & 6D-1H-2 / MEM, 54-64 cm & 53.04 & 53.14 & 1.86 & 152 & 0.093 & 59.5 & 0.061 \\
\hline 38 & & 6D-2E-1 / MEM, 41-51 cm & 54.57 & 54.67 & 3.39 & 391 & 0.21 & 59.4 & 0.053 \\
\hline 39 & & 6E-1H-2 / MEM, 51-62 cm & 52.92 & 53.03 & 1.74 & 300 & 0.76 & 51.9 & 0.25 \\
\hline 40 & & 6E-2H-2 / MEM, 77-83 cm & 55.24 & 55.30 & 4.04 & 422 & 1.3 & 57.1 & 0.30 \\
\hline 44 & & 7A-1H-1 / MEM, 84-92 cm & 14.95 & 15.03 & 0.66 & 402 & 0.86 & 59.0 & 0.21 \\
\hline 45 & & 7A-1H-2 / MEM, 58-68 cm & 15.91 & 16.01 & 1.63 & 219 & 1.1 & 53.5 & 0.52 \\
\hline 46 & & 7A-2H-1 / MEM, 107-114 cm & 18.13 & 18.20 & 3.83 & 23.6 & 0.090 & 74.5 & 0.38 \\
\hline 47 & & 7A-2H-2 / MEM, 32-40 cm & 18.76 & 18.84 & 4.47 & 22.6 & 0.21 & 73.9 & 0.91 \\
\hline 48 & & 7A-2H-2 / MEM, 124-132 cm & 19.68 & 19.76 & 5.39 & 206 & 0.47 & 63.6 & 0.23 \\
\hline 49 & & 7A-3H-1 / MEM, 106-114 cm & 21.09 & 21.17 & 6.80 & 138 & 0.27 & 62.7 & 0.19 \\
\hline 50 & & 7A-3H-2 / MEM, 91-100 cm & 22.25 & 22.34 & 7.97 & 224 & 0.40 & 62.1 & 0.18 \\
\hline 51 & & 7A-4H-1 / MEM, 40-47 cm & 23.44 & 23.51 & 9.15 & 14.7 & 0.053 & 80.2 & 0.36 \\
\hline 52 & & 7A-4H-2 / MEM, 92-100 cm & 25.14 & 25.22 & 10.85 & 140 & 1.5 & 33.6 & 1.1 \\
\hline 58 & & 7B-3H-1 / MEM, 74-82 cm & 30.64 & 30.72 & 16.35 & 39.8 & 0.15 & 75.3 & 0.37 \\
\hline 59 & & 7B-3H-2 / MEM, 24-34 cm & 31.38 & 31.48 & 17.10 & 94.5 & 0.49 & 74.9 & 0.52 \\
\hline 60 & & 7B-4H-1 / MEM, 54-65 cm & 33.00 & 33.11 & 18.73 & 76.3 & 1.3 & 69.2 & 1.7 \\
\hline 61 & & 7B-5H-1 / MEM, 57-71 cm & 33.86 & 33.98 & 19.59 & 100 & 1.1 & 68.5 & 1.1 \\
\hline 62 & 1 of 2 & 7B-5H-1 / MEM, 95-107 cm & 34.17 & 34.27 & 19.89 & 233 & 0.77 & 67.7 & 0.33 \\
\hline 62 & 2 of 2 & 7B-5H-1 / MEM, 95-107 cm & 34.17 & 34.27 & 19.89 & 247 & - & 67.7 & - \\
\hline 63 & & 7B-6H-1 / MEM, 37-49 cm & 34.57 & 34.68 & 20.29 & 298 & 2.0 & 64.8 & 0.65 \\
\hline 64 & & 7B-7H-1 / MEM, 95-113 cm & 36.30 & 36.48 & 22.06 & 259 & 0.98 & 67.1 & 0.38 \\
\hline 65 & & 7B-8H-1 / MEM, 103-114 cm & 37.86 & 37.97 & 23.59 & 154 & 0.20 & 71.9 & 0.13 \\
\hline 66 & & 7B-9H-1 / MEM, 72-82 cm & 39.09 & 39.19 & 24.81 & 635 & 0.50 & 65.3 & 0.079 \\
\hline 67 & & 7B-10H-1 / MEM, 61-72 cm & 40.48 & 40.59 & 26.21 & 997 & 0.18 & 67.7 & 0.018 \\
\hline 68 & & 7B-11H-1 / MEM, 3-15 cm & 41.45 & 41.56 & 27.18 & 123 & 0.53 & 73.6 & 0.43 \\
\hline 69 & & 7B-11H-2 / MEM, 54-64 cm & 43.37 & 43.47 & 29.09 & 239 & 0.98 & 67.9 & 0.41 \\
\hline 70 & & 7B-12H-1 / MEM, 7-19 cm & 44.48 & 44.60 & 30.21 & 87.7 & 0.23 & 65.9 & 0.26 \\
\hline
\end{tabular}


Table 3. Mercury and methylmercury data from the MEM series of subsamples from deep cores, Englebright Lake, California, May-June 2002-Continued.

[Analyses by Battelle Marine Sciences Laboratory, Sequim, Wash. mbls, meters below lake surface (spillway elevation); mblf, meters below lake floor; $\mathrm{Hg}_{\mathrm{T}}$, total mercury; MeHg, methylmercury; ng/g, nanogram per gram; \%, percentage; —, not determined; <, less than]

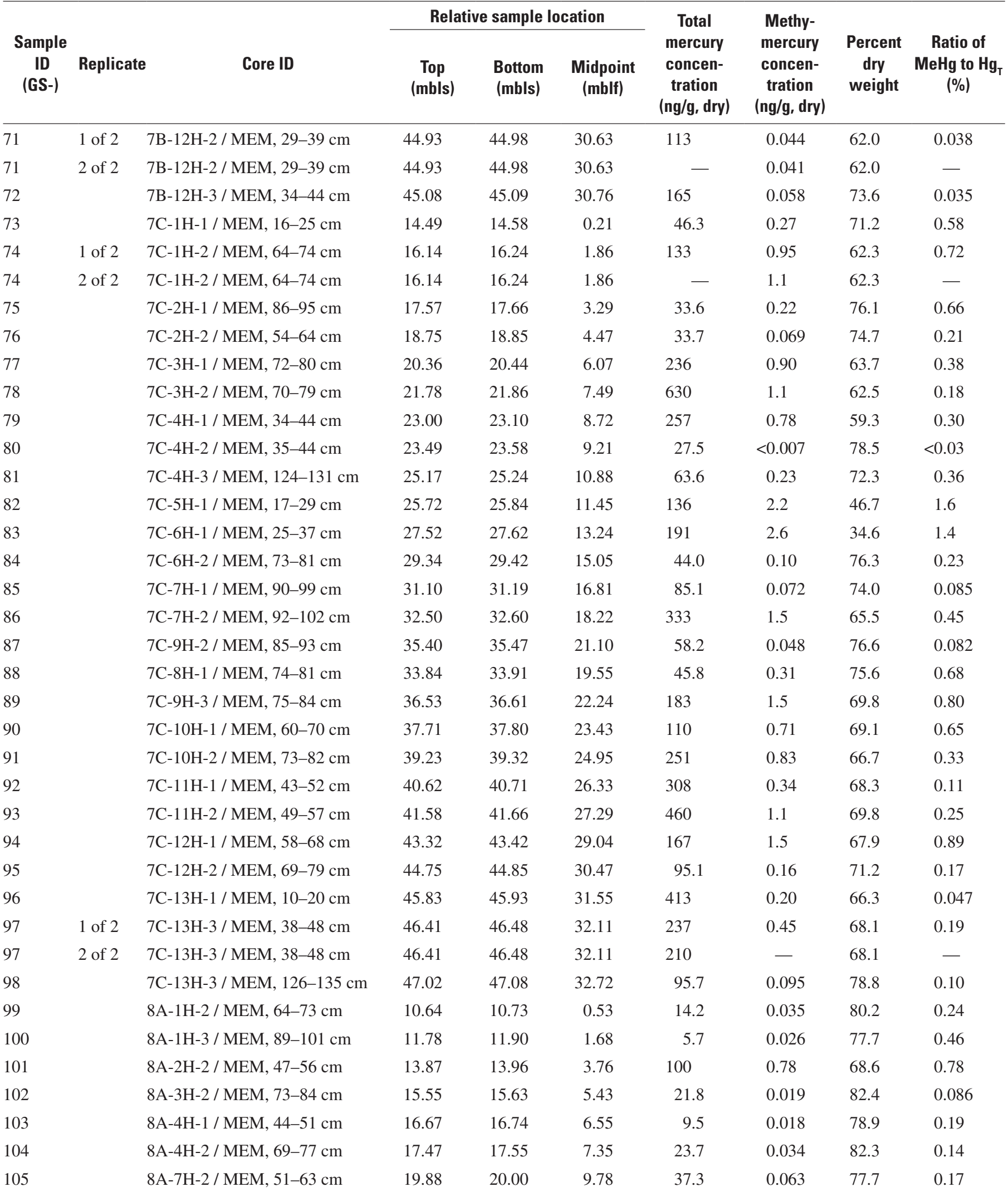


Table 3. Mercury and methylmercury data from the MEM series of subsamples from deep cores, Englebright Lake, California, May-June 2002-Continued.

[Analyses by Battelle Marine Sciences Laboratory, Sequim, Wash. mbls, meters below lake surface (spillway elevation); mblf, meters below lake floor; $\mathrm{Hg}_{\mathrm{T}}$, total mercury; $\mathrm{MeHg}$, methylmercury; ng/g, nanogram per gram; \%, percentage; —, not determined; <, less than]

\begin{tabular}{|c|c|c|c|c|c|c|c|c|c|}
\hline \multirow{2}{*}{$\begin{array}{c}\text { Sample } \\
\text { ID } \\
\text { (GS-) }\end{array}$} & \multirow[b]{2}{*}{ Replicate } & \multirow[b]{2}{*}{ Core ID } & \multicolumn{3}{|c|}{ Relative sample location } & \multirow{2}{*}{$\begin{array}{c}\text { Total } \\
\text { mercury } \\
\text { concen- } \\
\text { tration } \\
\text { (ng/g, dry) }\end{array}$} & \multirow{2}{*}{$\begin{array}{l}\text { Methy- } \\
\text { mercury } \\
\text { concen- } \\
\text { tration } \\
\text { (ng/g, dry) }\end{array}$} & \multirow{2}{*}{$\begin{array}{c}\text { Percent } \\
\text { dry } \\
\text { weight }\end{array}$} & \multirow{2}{*}{$\begin{array}{c}\text { Ratio of } \\
\text { MeHg to } \mathrm{Hg}_{\mathrm{T}} \\
(\%)\end{array}$} \\
\hline & & & $\begin{array}{c}\text { Top } \\
\text { (mbls) }\end{array}$ & $\begin{array}{l}\text { Bottom } \\
\text { (mbls) }\end{array}$ & $\begin{array}{l}\text { Midpoint } \\
\text { (mblf) }\end{array}$ & & & & \\
\hline 106 & & 8A-8H-1 / MEM, 110-118 cm & 22.40 & 22.48 & 12.28 & 7.6 & 0.009 & 84.1 & 0.12 \\
\hline 107 & & 8A-8H-2 / MEM, 0-13 cm & 22.71 & 22.73 & 12.56 & 201 & 0.20 & 65.4 & 0.10 \\
\hline 109 & & 8A-11H-1 / MEM, 76-83 cm & 25.28 & 25.35 & 15.16 & 142 & 0.86 & 61.6 & 0.61 \\
\hline 110 & & 8A-12H-1 / MEM, 38-52 cm & 26.41 & 26.55 & 16.32 & 174 & 0.57 & 63.7 & 0.33 \\
\hline 111 & & 8A-12H-2 / MEM, 38-47 cm & 27.77 & 27.86 & 17.65 & 109 & 0.42 & 71.7 & 0.38 \\
\hline 112 & 1 of 2 & 8A-13H-1 / MEM, 68-78 cm & 29.50 & 29.60 & 19.39 & 95.0 & 0.14 & 71.7 & 0.15 \\
\hline 115 & & 8A-14H-2 / MEM, 25-33 cm & 32.92 & 33.00 & 22.80 & 365 & 0.24 & 70.9 & 0.065 \\
\hline 116 & & 8B-1H-1 / MEM, 30-38 cm & 11.48 & 11.56 & 1.36 & 18.1 & 0.016 & 83.2 & 0.090 \\
\hline 117 & & 8B-1H-2 / MEM, 69-78 cm & 12.67 & 12.76 & 2.56 & 23.1 & $<0.007$ & 79.8 & $<0.03$ \\
\hline 118 & & 8B-2H-1 / MEM, 104-112 cm & 15.24 & 15.32 & 5.12 & 110 & 0.15 & 70.0 & 0.14 \\
\hline 119 & & 8B-2H-2 / MEM, 62-71 cm & 16.04 & 16.13 & 5.93 & 16.4 & 0.019 & 79.2 & 0.12 \\
\hline 120 & & 8B-3H-1 / MEM, 50-58 cm & 17.67 & 17.75 & 7.55 & 18.0 & 0.022 & 82.9 & 0.12 \\
\hline 121 & & 8B-3H-2 / MEM, 117-127 cm & 19.17 & 19.27 & 9.06 & 15.5 & 0.097 & 73.5 & 0.63 \\
\hline 122 & & 8C-2H-1 / MEM, 92-101 cm & 20.05 & 20.14 & 9.94 & 81.6 & 0.32 & 72.9 & 0.39 \\
\hline 123 & 1 of 2 & 8C-2H-2 / MEM, 52-61 cm & 20.93 & 21.01 & 10.81 & 302 & 0.94 & 64.7 & 0.31 \\
\hline 127 & & 8C-4H-2 / MEM, 77-87 cm & 26.56 & 26.65 & 16.45 & 102 & 0.71 & 70.0 & 0.69 \\
\hline 128 & & 8C-5H-1 / MEM, 56-65 cm & 27.87 & 27.96 & 17.76 & 100 & 0.19 & 69.0 & 0.19 \\
\hline 129 & & 8C-5H-2 / MEM, 26-36 cm & 28.93 & 29.03 & 18.82 & 181 & 0.33 & 63.7 & 0.18 \\
\hline 130 & 1 of 2 & 8C-6H-1 / MEM, 69-79 cm & 30.97 & 31.06 & 20.86 & 130 & 0.074 & 65.6 & 0.057 \\
\hline 130 & 2 of 2 & 8C-6H-1 / MEM, 69-79 cm & 30.97 & 31.06 & 20.86 & - & 0.087 & 65.6 & - \\
\hline 131 & & 8C-6H-3 / MEM, 40-50 cm & 32.13 & 32.22 & 22.01 & 133 & 0.62 & 69.4 & 0.46 \\
\hline 132 & 1 of 2 & 8C-7H-1 / MEM, 18-28 cm & 33.41 & 33.50 & 23.29 & 128 & 0.17 & 60.7 & 0.13 \\
\hline 132 & 2 of 2 & 8C-7H-1 / MEM, 18-28 cm & 33.41 & 33.50 & 23.29 & 124 & - & 60.7 & - \\
\hline 133 & & 9A-1H-1 / MEM, 90-103 cm & 11.31 & 11.42 & 0.80 & 35.6 & 0.092 & 74.8 & 0.26 \\
\hline 134 & & 9A-1H-2 / MEM, 83-94 cm & 12.43 & 12.53 & 1.92 & 216 & 1.7 & 57.9 & 0.77 \\
\hline 135 & & 9A-2H-1 / MEM, 49-56 cm & 13.94 & 14.01 & 3.41 & 119 & 0.55 & 66.2 & 0.46 \\
\hline 136 & & 9A-2H-3 / MEM, 110-119 cm & 15.74 & 15.83 & 5.23 & 20.1 & 0.027 & 77.8 & 0.14 \\
\hline 137 & & 9A-3H-1 / MEM, 72-80 cm & 16.65 & 16.73 & 6.13 & 21.3 & 0.020 & 78.9 & 0.10 \\
\hline 138 & & 9A-3H-2 / MEM, 39-48 cm & 17.46 & 17.55 & 6.95 & 70.7 & 0.43 & 65.2 & 0.61 \\
\hline
\end{tabular}


Table 3. Mercury and methylmercury data from the MEM series of subsamples from deep cores, Englebright Lake, California, May-June 2002-Continued.

[Analyses by Battelle Marine Sciences Laboratory, Sequim, Wash. mbls, meters below lake surface (spillway elevation); mblf, meters below lake floor; $\mathrm{Hg}_{\mathrm{T}}$, total mercury; MeHg, methylmercury; ng/g, nanogram per gram; \%, percentage; —, not determined; <, less than]

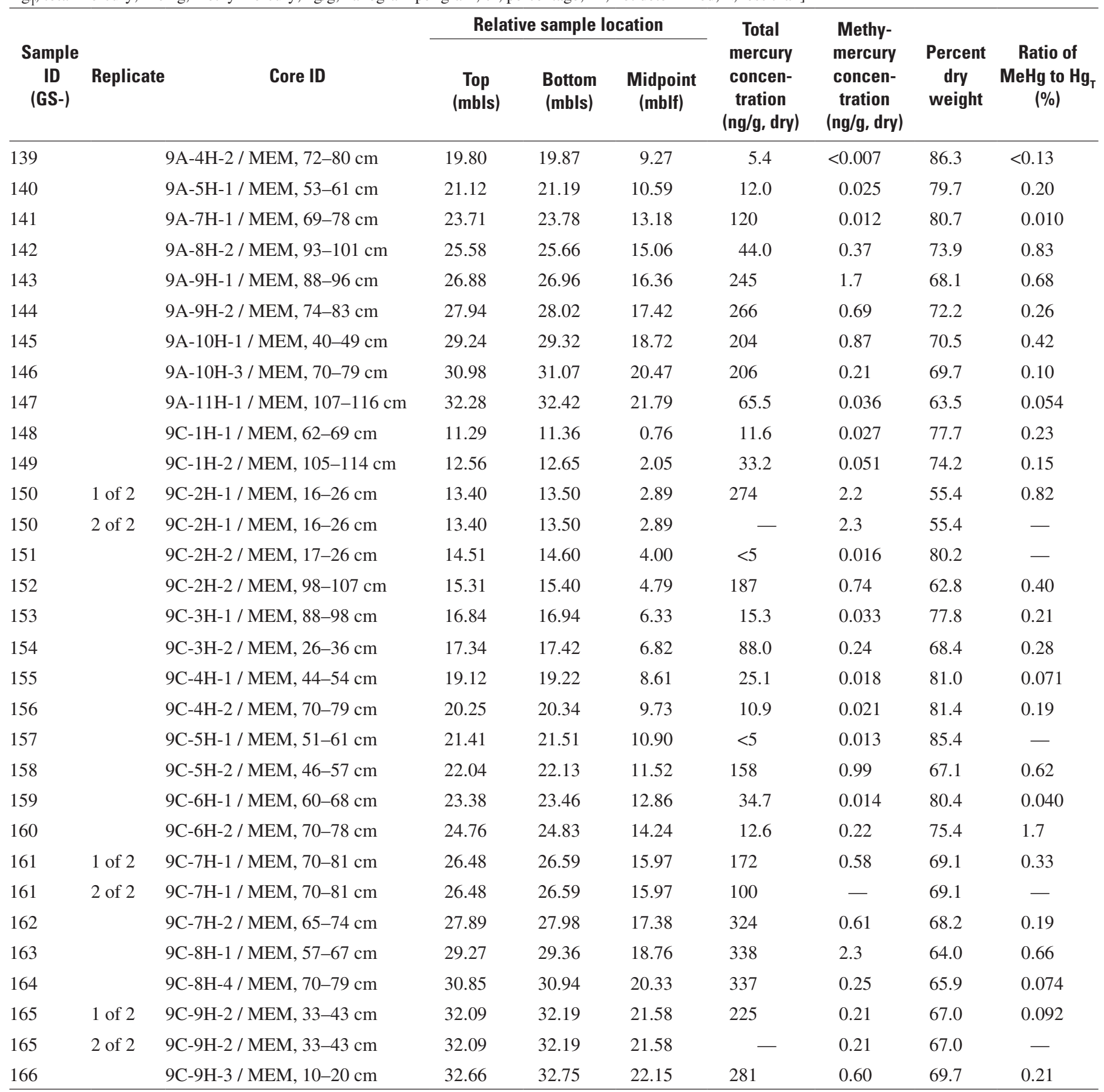


Table 4. Mercury and methylmercury data for shallow cores taken at Englebright Lake, California, October 2002.

[Analyses by Battelle Marine Sciences Laboratory, Sequim, Wash. MeHg, methylmercury; $\mathrm{Hg}_{\mathrm{T}}$, total mercury. cm, centimeter; ng/g, nanograms per gram; - , not determined]

\begin{tabular}{|c|c|c|c|c|c|c|c|c|}
\hline Site ID & $\begin{array}{l}\text { Depth below } \\
\text { lake floor } \\
\text { (cm) }\end{array}$ & Lab ID & $\begin{array}{c}\text { Core } \\
\text { replicate }\end{array}$ & $\begin{array}{l}\text { Lab } \\
\text { replicate }\end{array}$ & $\begin{array}{l}\text { Percent } \\
\text { dry } \\
\text { weight }\end{array}$ & $\begin{array}{c}\text { Total } \\
\text { mercury } \\
\text { (ng/g dry) }\end{array}$ & $\begin{array}{l}\text { Methyl- } \\
\text { mercury } \\
\text { (ng/g dry) }\end{array}$ & $\begin{array}{c}\text { Ratio of } \\
\mathrm{MeHg} \text { to } \\
\mathrm{Hg}_{\mathrm{T}} \\
\text { (percentage) }\end{array}$ \\
\hline $10 \mathrm{~F}-\mathrm{B}$ & $0-1$ & GS 200 & & & 23.4 & 307 & 1.1 & 0.37 \\
\hline $10 \mathrm{~F}-\mathrm{B}$ & $1-2$ & GS 201 & & & 29.7 & 251 & 1.0 & 0.40 \\
\hline $10 \mathrm{~F}-\mathrm{B}$ & $2-3$ & GS 202 & & & 32.8 & 303 & 0.90 & 0.30 \\
\hline $10 \mathrm{~F}-\mathrm{B}$ & $3-4$ & GS 203 & & & 37.3 & 283 & 0.86 & 0.30 \\
\hline $10 \mathrm{~F}-\mathrm{B}$ & $4-8$ & GS 204 & 1 of 2 & & 43.9 & 256 & 0.47 & 0.18 \\
\hline $10 \mathrm{~F}-\mathrm{B}$ & $4-8$ & GS 205 & 2 of 2 & & 43.2 & 243 & 0.80 & 0.33 \\
\hline $10 \mathrm{~F}-\mathrm{B}$ & $8-12$ & GS 206 & & & 49.7 & 265 & 0.71 & 0.27 \\
\hline 10G-B & $0-1$ & GS 207 & & & 26.8 & 224 & 0.92 & 0.41 \\
\hline 10G-B & $1-2$ & GS 208 & & & 30.6 & 288 & 1.5 & 0.51 \\
\hline 10G-B & $2-3$ & GS 209 & & 1 of 2 & 33.2 & 258 & 0.73 & 0.28 \\
\hline 10G-B & $2-3$ & GS 209 & & 2 of 2 & 33.2 & - & 0.89 & - \\
\hline 10G-B & $3-4$ & GS 210 & & & 37.6 & 288 & 0.60 & 0.21 \\
\hline 10G-B & $4-8$ & GS 211 & & & 43.0 & 265 & 0.96 & 0.36 \\
\hline 10G-B & $8-12$ & GS 212 & 1 of 2 & & 47.0 & 274 & 1.1 & 0.40 \\
\hline 10G-B & $8-12$ & GS 213 & 2 of 2 & & 47.3 & 237 & 1.0 & 0.43 \\
\hline $11 \mathrm{~A}-\mathrm{B}$ & $0-4$ & GS 214 & & & 36.2 & 252 & 1.7 & 0.66 \\
\hline $11 \mathrm{~A}-\mathrm{B}$ & $4-8$ & GS 215 & & 1 of 4 & 44.4 & 228 & 0.57 & 0.25 \\
\hline $11 \mathrm{~A}-\mathrm{B}$ & $4-8$ & GS 215 & & 2 of 4 & 44.4 & - & 0.87 & - \\
\hline $11 \mathrm{~A}-\mathrm{B}$ & $4-8$ & GS 215 & & 3 of 4 & 44.4 & - & 0.90 & - \\
\hline $11 \mathrm{~A}-\mathrm{B}$ & $4-8$ & GS 215 & & 4 of 4 & 44.4 & - & 0.49 & - \\
\hline $11 \mathrm{~A}-\mathrm{B}$ & $8-12$ & GS 216 & & & 44.4 & 233 & 0.43 & 0.18 \\
\hline 11B-B & $0-4$ & GS 217 & & & 27.9 & 230 & 0.40 & 0.17 \\
\hline 11B-B & $4-8$ & GS 218 & & 1 of 2 & 37.5 & 380 & 0.37 & 0.10 \\
\hline 11B-B & $4-8$ & GS 218 & & 2 of 2 & 37.5 & 295 & - & - \\
\hline 11B-B & $8-12$ & GS 219 & & & 41.1 & 298 & 0.52 & 0.18 \\
\hline 11C-B1 & $0-4$ & GS 220 & 1 of 1 & & 30.5 & 329 & 0.85 & 0.26 \\
\hline 11C-B1 & $4-8$ & GS 221 & 1 of 1 & & 48.1 & 228 & 0.41 & 0.18 \\
\hline 11C-B1 & $8-12$ & GS 222 & 1 of 1 & & 48.9 & 227 & 0.49 & 0.21 \\
\hline 11C-B2 & $0-4$ & GS 223 & 2 of 2 & & 35.1 & 285 & 0.49 & 0.17 \\
\hline $11 \mathrm{C}-\mathrm{B} 2$ & $4-8$ & GS 224 & 2 of 2 & & 48.4 & 270 & 0.25 & 0.091 \\
\hline $11 \mathrm{C}-\mathrm{B} 2$ & $8-12$ & GS 225 & 2 of 2 & & 48.7 & 268 & 0.58 & 0.21 \\
\hline 11D-B & $0-4$ & GS 226 & & & 40.5 & 271 & 0.56 & 0.21 \\
\hline 11D-B & $4-8$ & GS 227 & & & 50.4 & 222 & 0.33 & 0.15 \\
\hline 11D-B & $8-11$ & GS 228 & & & 46.9 & 222 & 0.55 & 0.25 \\
\hline $11 \mathrm{E}-\mathrm{B}$ & $0-4$ & GS 229 & & & 40.3 & 245 & 4.0 & 1.6 \\
\hline $11 \mathrm{E}-\mathrm{B}$ & $4-7$ & GS 230 & & & 41.7 & 212 & 3.8 & 1.8 \\
\hline $11 \mathrm{~F}-\mathrm{B}$ & $0-1$ & GS 231 & & & 29.1 & 308 & 1.1 & 0.35 \\
\hline $11 \mathrm{~F}-\mathrm{B}$ & $1-2$ & GS 232 & & & 39.5 & 333 & 0.69 & 0.21 \\
\hline
\end{tabular}


Table 4. Mercury and methylmercury data for shallow cores taken at Englebright Lake, California, October 2002—Continued.

[Analyses by Battelle Marine Sciences Laboratory, Sequim, Wash. MeHg, methylmercury; $\mathrm{Hg}_{\mathrm{T}}$, total mercury. cm, centimeter; ng/g, nanograms per gram; -, not determined]

\begin{tabular}{|c|c|c|c|c|c|c|c|c|}
\hline Site ID & $\begin{array}{l}\text { Depth below } \\
\text { lake floor } \\
\text { (cm) }\end{array}$ & Lab ID & $\begin{array}{c}\text { Core } \\
\text { replicate }\end{array}$ & $\begin{array}{l}\text { Lab } \\
\text { replicate }\end{array}$ & $\begin{array}{l}\text { Percent } \\
\text { dry } \\
\text { weight }\end{array}$ & $\begin{array}{c}\text { Total } \\
\text { mercury } \\
\text { (ng/g dry) }\end{array}$ & $\begin{array}{l}\text { Methyl- } \\
\text { mercury } \\
\text { (ng/g dry) }\end{array}$ & $\begin{array}{c}\text { Ratio of } \\
\mathrm{MeHg} \text { to } \\
\mathrm{Hg}_{\mathrm{T}} \\
\text { (percentage) }\end{array}$ \\
\hline $11 \mathrm{~F}-\mathrm{B}$ & $2-3$ & GS 233 & & 1 of 2 & 48.3 & 265 & 0.47 & 0.18 \\
\hline $11 \mathrm{~F}-\mathrm{B}$ & $2-3$ & GS 233 & & 2 of 2 & 48.3 & - & 0.48 & - \\
\hline $11 \mathrm{~F}-\mathrm{B}$ & $3-4$ & GS 234 & & & 51.1 & 240 & 0.37 & 0.16 \\
\hline $11 \mathrm{~F}-\mathrm{B}$ & $4-8$ & GS 235 & & 1 of 2 & 50.2 & 269 & 0.46 & 0.17 \\
\hline $11 \mathrm{~F}-\mathrm{B}$ & $4-8$ & GS 235 & & 2 of 2 & 50.2 & 264 & - & - \\
\hline $11 \mathrm{~F}-\mathrm{B}$ & $8-9$ & GS 236 & & & 51.1 & 218 & 0.32 & 0.14 \\
\hline 11G-B & $0-4$ & GS 237 & & & 42.8 & 246 & 0.68 & 0.28 \\
\hline 11G-B & $4-8$ & GS 238 & & & 49.9 & 251 & 0.32 & 0.13 \\
\hline 11G-B & $8-12$ & GS 239 & & & 48.8 & 244 & 0.48 & 0.20 \\
\hline $12 \mathrm{~A}-\mathrm{B}$ & $0-4$ & GS 240 & & & 36.5 & 245 & 1.4 & 0.58 \\
\hline $12 \mathrm{~A}-\mathrm{B}$ & $4-8$ & GS 241 & & & 48.1 & 248 & 1.4 & 0.55 \\
\hline $12 \mathrm{~A}-\mathrm{B}$ & $8-10$ & GS 242 & & & 49.7 & 251 & 0.63 & 0.25 \\
\hline $12 \mathrm{~B}-\mathrm{B}$ & $0-2$ & GS 243 & & & 39.1 & 174 & 0.75 & 0.43 \\
\hline 12B-B & $2-4$ & GS 244 & & & 50.4 & 240 & 0.87 & 0.36 \\
\hline $12 \mathrm{~B}-\mathrm{B}$ & $4-7.5$ & GS 245 & & & 57.1 & 184 & 0.45 & 0.25 \\
\hline $12 \mathrm{C}-\mathrm{B}$ & $0-2$ & GS 246 & & & 47.6 & 243 & 1.0 & 0.41 \\
\hline $12 \mathrm{C}-\mathrm{B}$ & $2-4$ & GS 247 & & 1 of 2 & 61.6 & 148 & 0.73 & 0.49 \\
\hline $12 \mathrm{C}-\mathrm{B}$ & $2-4$ & GS 247 & & 2 of 2 & 61.6 & - & 0.75 & - \\
\hline $12 \mathrm{C}-\mathrm{B}$ & $4-5.5$ & GS 248 & & 1 of 2 & 69.0 & 91.4 & 0.52 & 0.57 \\
\hline $12 \mathrm{C}-\mathrm{B}$ & $4-5.5$ & GS 248 & & 2 of 2 & 69.0 & 101 & - & - \\
\hline $12 \mathrm{D}-\mathrm{B}$ & $0-2$ & GS 249 & & & 44.8 & 201 & 1.2 & 0.60 \\
\hline $12 \mathrm{D}-\mathrm{B}$ & $2-4$ & GS 250 & & & 52.3 & 228 & 1.2 & 0.54 \\
\hline $12 \mathrm{D}-\mathrm{B}$ & $4-7$ & GS 251 & & & 59.1 & 139 & 0.95 & 0.68 \\
\hline $12 \mathrm{E}-\mathrm{B}$ & $2-4$ & GS 252 & & & 51.9 & 175 & 1.3 & 0.75 \\
\hline $12 \mathrm{E}-\mathrm{B}$ & $4-6$ & GS 253 & & & 54.0 & 204 & 0.93 & 0.45 \\
\hline $13-\mathrm{B}$ & $0-4$ & GS 254 & & & 39.4 & 230 & 0.80 & 0.35 \\
\hline $13-\mathrm{B}$ & $4-8$ & GS 255 & & & 49.5 & 240 & 0.41 & 0.17 \\
\hline $13-\mathrm{B}$ & $8-12$ & GS 256 & & & 53.0 & 226 & 0.49 & 0.22 \\
\hline $14-B$ & $0-4$ & GS 257 & & & 32.9 & 225 & 0.69 & 0.31 \\
\hline $14-B$ & $4-8$ & GS 258 & & 1 of 2 & 43.7 & 241 & 0.62 & 0.26 \\
\hline $14-B$ & $4-8$ & GS 258 & & 2 of 2 & 43.7 & - & 0.70 & - \\
\hline $14-\mathrm{B}$ & $8-12$ & GS 259 & & & 47.8 & 233 & 0.81 & 0.35 \\
\hline $15-B$ & $0-4$ & GS 260 & & & 31.4 & 263 & 1.0 & 0.39 \\
\hline $15-\mathrm{B}$ & $4-8$ & GS 261 & & & 43.0 & 281 & 1.2 & 0.44 \\
\hline $15-\mathrm{B}$ & $8-12$ & GS 262 & & & 47.9 & 261 & 1.2 & 0.48 \\
\hline $16-\mathrm{B}$ & $0-4$ & GS 263 & & & 31.8 & 267 & 0.56 & 0.21 \\
\hline $16-\mathrm{B}$ & $4-8$ & GS 264 & & & 46.8 & 258 & 1.4 & 0.54 \\
\hline $17-B$ & $0-4$ & GS 265 & & & 38.0 & 220 & 0.43 & 0.20 \\
\hline
\end{tabular}


Table 4. Mercury and methylmercury data for shallow cores taken at Englebright Lake, California, 0ctober 2002-Continued.

[Analyses by Battelle Marine Sciences Laboratory, Sequim, Wash. MeHg, methylmercury; $\mathrm{Hg}_{\mathrm{T}}$, total mercury. cm, centimeter; ng/g, nanograms per gram; -, not determined]

\begin{tabular}{|c|c|c|c|c|c|c|c|c|}
\hline Site ID & $\begin{array}{l}\text { Depth below } \\
\text { lake floor } \\
\text { (cm) }\end{array}$ & Lab ID & $\begin{array}{c}\text { Core } \\
\text { replicate }\end{array}$ & $\begin{array}{l}\text { Lab } \\
\text { replicate }\end{array}$ & $\begin{array}{l}\text { Percent } \\
\text { dry } \\
\text { weight }\end{array}$ & $\begin{array}{c}\text { Total } \\
\text { mercury } \\
\text { (ng/g dry) }\end{array}$ & $\begin{array}{l}\text { Methyl- } \\
\text { mercury } \\
\text { (ng/g dry) }\end{array}$ & $\begin{array}{c}\text { Ratio of } \\
\mathrm{MeHg} \mathrm{Ho} \\
\mathrm{Hg}_{\mathrm{T}} \\
\text { (percentage) }\end{array}$ \\
\hline $17-B$ & $4-8$ & GS 266 & & & 48.9 & 220 & 0.47 & 0.21 \\
\hline 17-B & $8-10$ & GS 267 & & 1 of 2 & 53.5 & 200 & 0.43 & 0.22 \\
\hline $17-\mathrm{B}$ & $8-10$ & GS 267 & & 2 of 2 & 53.5 & 197 & - & - \\
\hline $18-\mathrm{B}$ & $0-4$ & GS 268 & & & 30.6 & 253 & 1.6 & 0.64 \\
\hline 18-B & $4-8$ & GS 269 & & & 40.6 & 257 & 1.2 & 0.47 \\
\hline $18-\mathrm{B}$ & $8-12$ & GS 270 & & & 52.8 & 334 & 0.87 & 0.26 \\
\hline 19-B & $0-4$ & GS 271 & & & 38.5 & 241 & 2.3 & 0.96 \\
\hline 19-B & $4-8$ & GS 272 & & 1 of 2 & 51.0 & 232 & 1.8 & 0.78 \\
\hline 19-B & $4-8$ & GS 272 & & 2 of 2 & 51.0 & - & 1.7 & - \\
\hline 19-B & $8-10$ & GS 273 & & & 51.5 & 219 & 1.8 & 0.82 \\
\hline $23 \mathrm{~A}-\mathrm{B}$ & $0-1$ & GS 274 & & & 32.3 & 176 & 1.1 & 0.62 \\
\hline $23 \mathrm{~A}-\mathrm{B}$ & $1-2$ & GS 275 & & & 38.3 & 428 & 1.1 & 0.26 \\
\hline $23 \mathrm{~A}-\mathrm{B}$ & $2-3$ & GS 276 & & & 38.5 & 261 & 1.3 & 0.48 \\
\hline $23 \mathrm{~A}-\mathrm{B}$ & $3-4$ & GS 277 & & & 41.6 & 257 & 1.3 & 0.50 \\
\hline $23 \mathrm{~A}-\mathrm{B}$ & $4-8$ & GS 278 & & & 47.1 & 258 & 0.89 & 0.34 \\
\hline $23 \mathrm{~A}-\mathrm{B}$ & $8-10$ & GS 279 & & & 56.2 & 3,430 & 1.4 & 0.040 \\
\hline $23 \mathrm{~A}-\mathrm{B}$ & $0-4$ & GS 280 & & & 45.4 & - & 1.4 & - \\
\hline $12 \mathrm{E}-\mathrm{B}$ & $0-2$ & GS-282 & & 1 of 2 & 47.5 & 216 & 1.2 & 0.56 \\
\hline $12 \mathrm{E}-\mathrm{B}$ & $0-2$ & GS-282 & & 2 of 2 & 47.5 & - & 1.0 & - \\
\hline
\end{tabular}



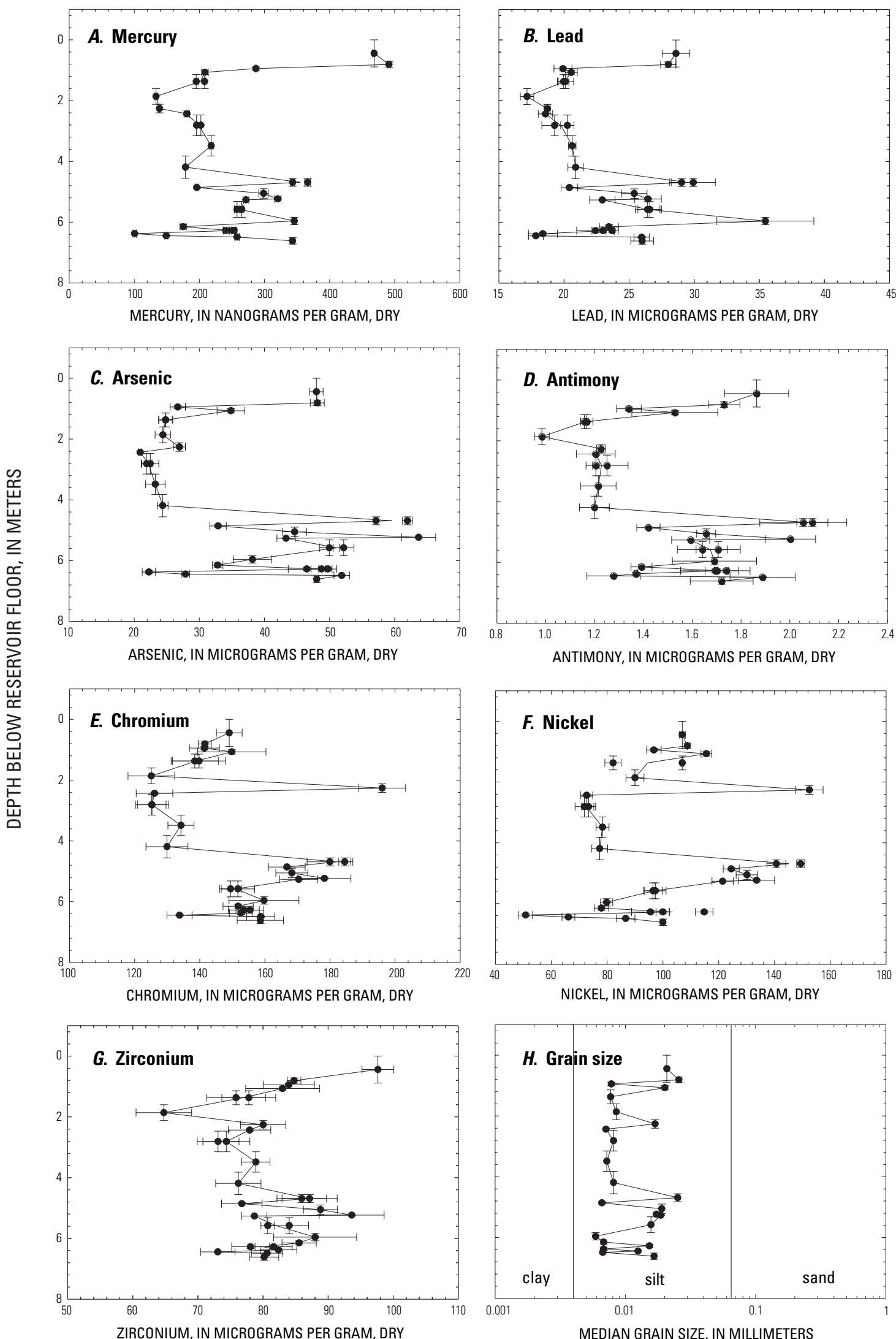

Figure 4. Deep coring profiles showing concentrations of trace metals and median grain size in sieved sediment subsamples (Y-series) from site 1 at Englebright Lake, California, May-June, 2002: $(A)$ Mercury, $(B)$ Lead, $(C)$ Arsenic, $(D)$ Antimony, $(E)$ Chromium, $(F)$ Nickel, $(G)$ Zirconium, and $(H)$ Median grain size. Grain-size data from Snyder and others (2004b). Lines represent vertical trends of concentration values. Horizontal error bars represent standard deviation of multiple analyses. Vertical bars show depth intervals. Sieve size 0.06 millimeter. 

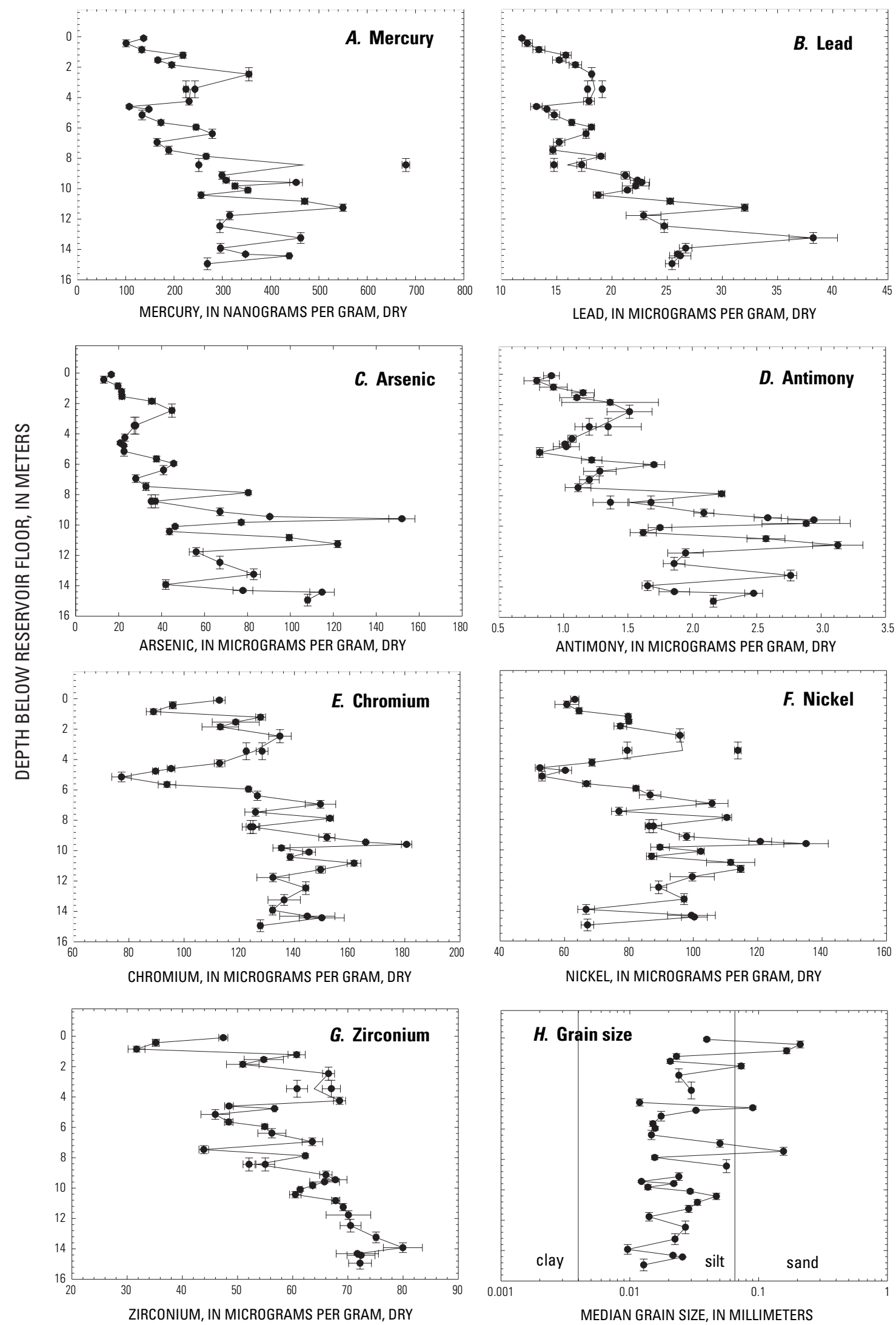

Figure 5. Deep coring profiles showing concentrations of trace metals and median grain size in unsieved sediment subsamples (Y-series) from site 4 at Englebright Lake, California, May-June, 2002: $(A)$ Mercury, $(B)$ Lead, $(C)$ Arsenic, $(D)$ Antimony, $(E)$ Chromium, $(F)$ Nickel, $(G)$ Zirconium, and $(H)$ Median grain size. Grain-size data from Snyder and others (2004b). Lines represent vertical trends of concentration values. Horizontal error bars represent standard deviation of multiple analyses. Vertical bars show depth intervals. 

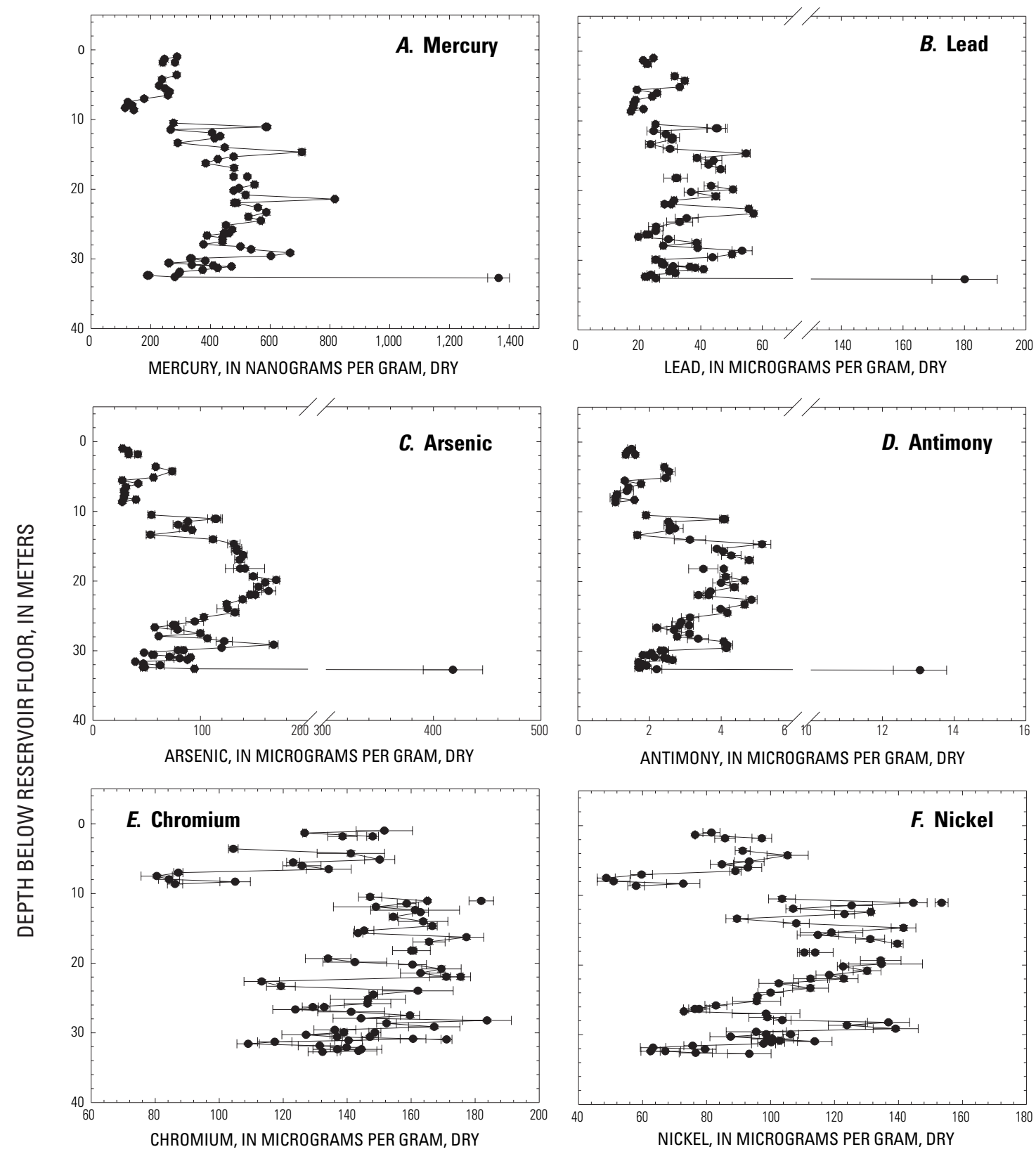

ANTIMONY, IN MICROGRAMS PER GRAM, DRY
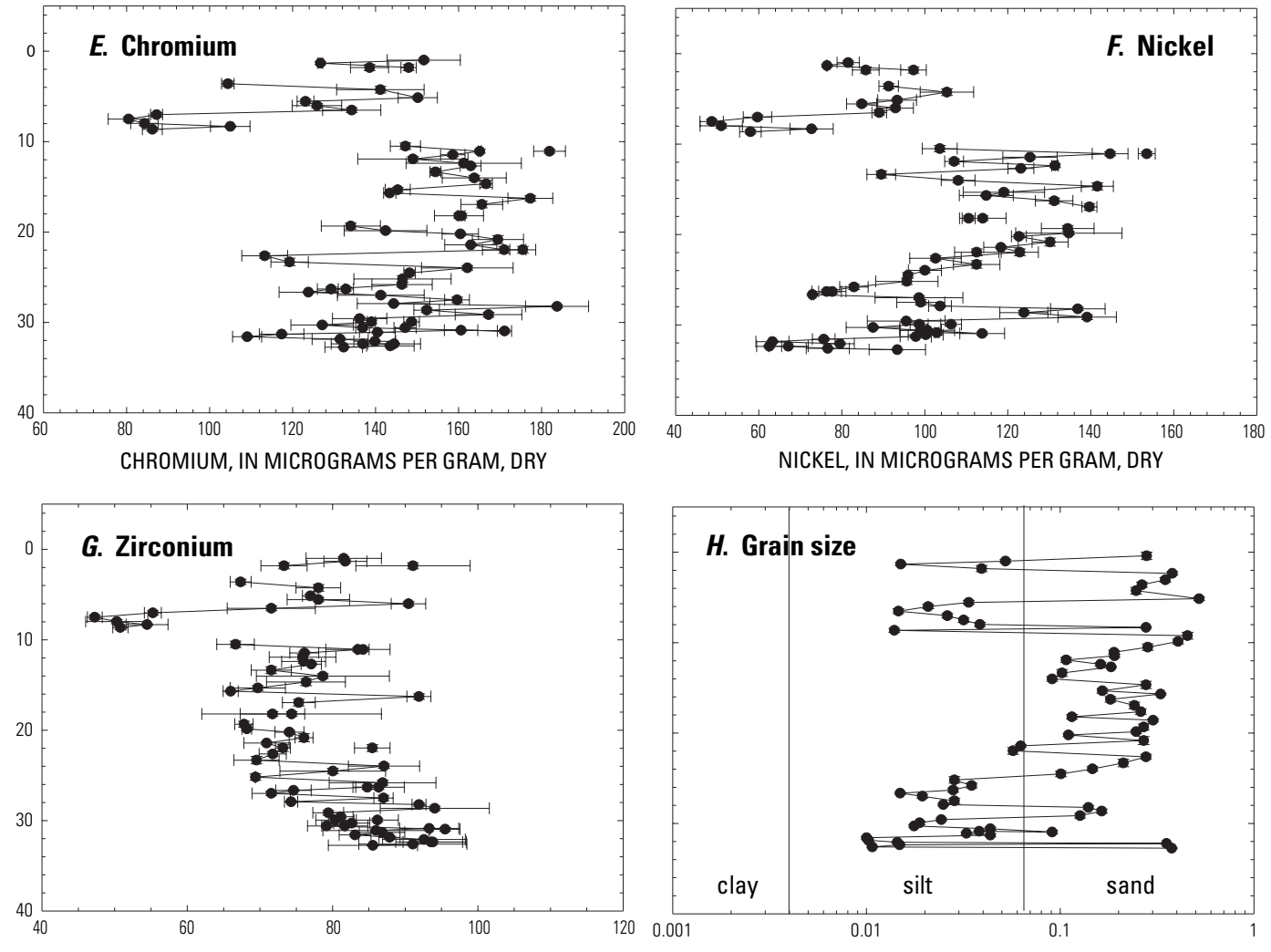

ZIRCONIUM, IN MICROGRAMS PER GRAM, DRY

MEDIAN GRAIN SIZE, IN MILLIMETERS

Figure 6. Deep coring profiles showing concentrations of trace metals and median grain size in sieved sediment subsamples (Y-series) from site 7 at Englebright Lake, California, May-June, 2002: $(A)$ Mercury, $(B)$ Lead, $(C)$ Arsenic, $(D)$ Antimony, $(E)$ Chromium, $(F)$ Nickel, $(G)$ Zirconium, and $(H)$ Median grain size. Grain-size data from Snyder and others (2004b). Lines represent vertical trends of concentration values. Horizontal error bars represent standard deviation of multiple analyses. Vertical bars show depth intervals. Sieve size 0.06 millimeter. 

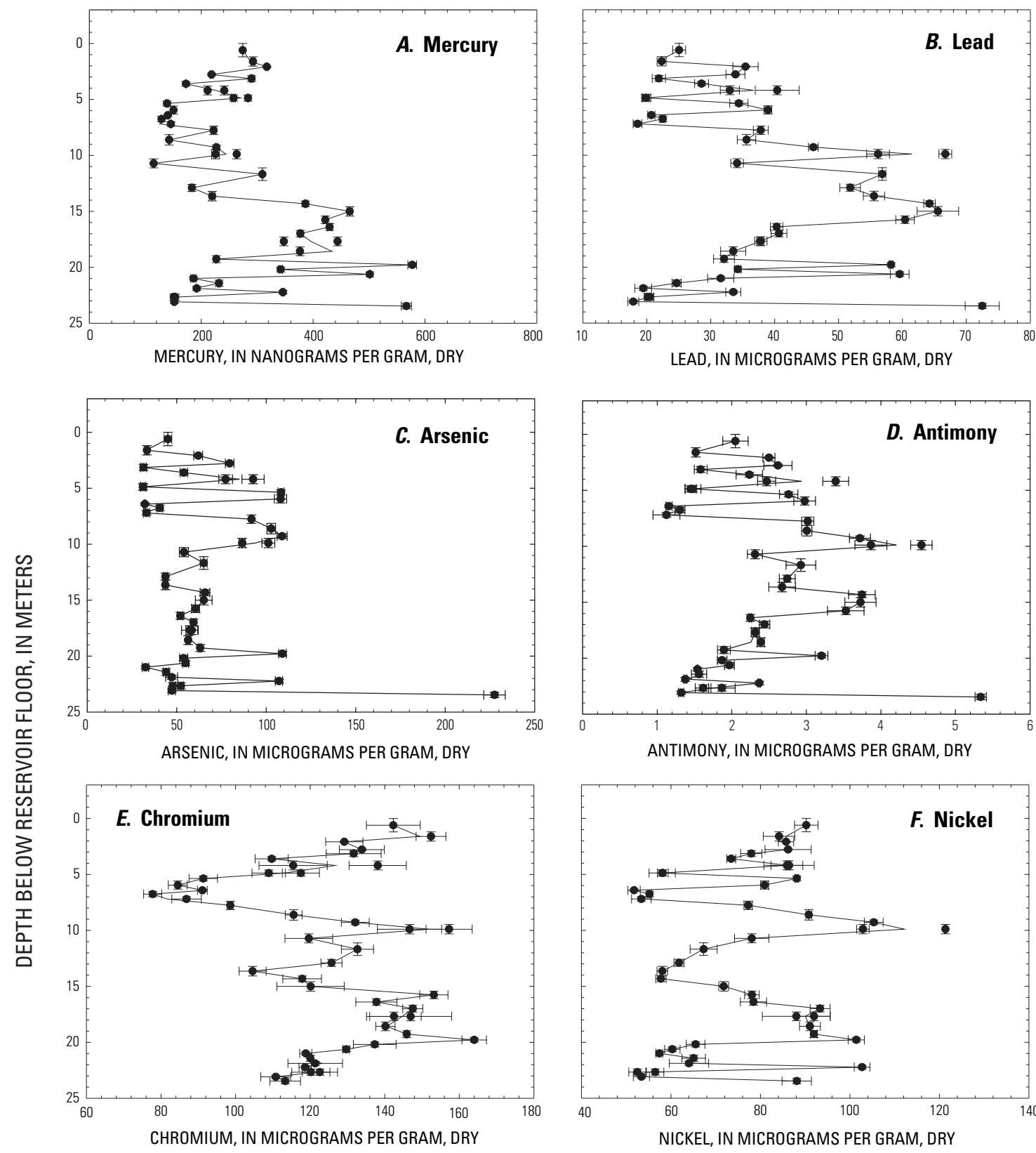

ANTIMONY, IN MICROGRAMS PER GRAM, DRY
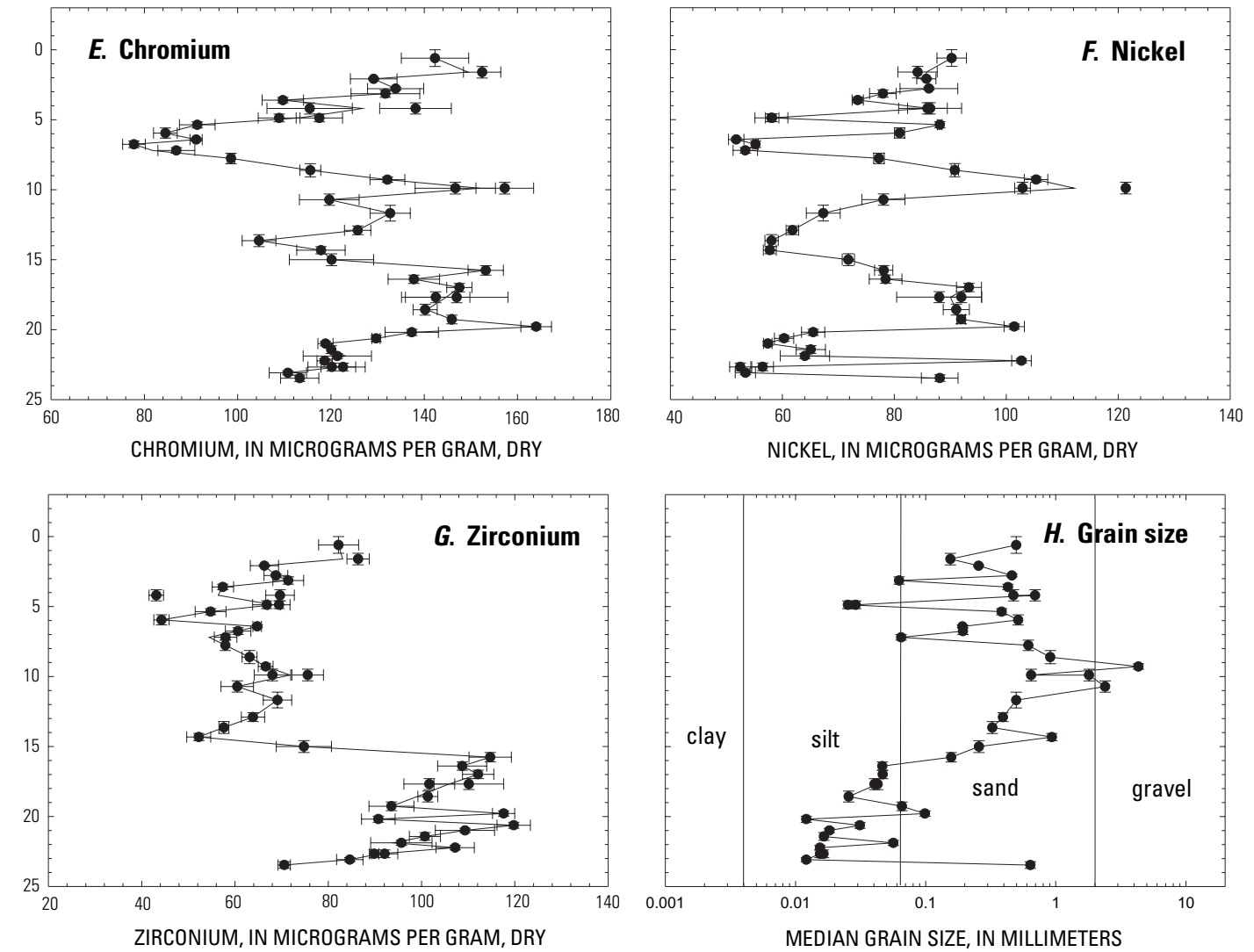

Figure 7. Deep coring profiles showing concentrations of trace metals and median grain size in sieved sediment subsamples (Y-series) from site 9 at Englebright Lake, California, May-June, 2002: $(A)$ Mercury, $(B)$ Lead, $(C)$ Arsenic, $(D)$ Antimony, $(E)$ Chromium, $(F)$ Nickel, $(G)$ Zirconium, and $(H)$ Median grain size. Grain-size data from Snyder and others (2004b). Lines represent vertical trends of concentration values. Horizontal error bars represent standard deviation of multiple analyses. Vertical bars show depth intervals. Sieve size 0.06 millimeter. 

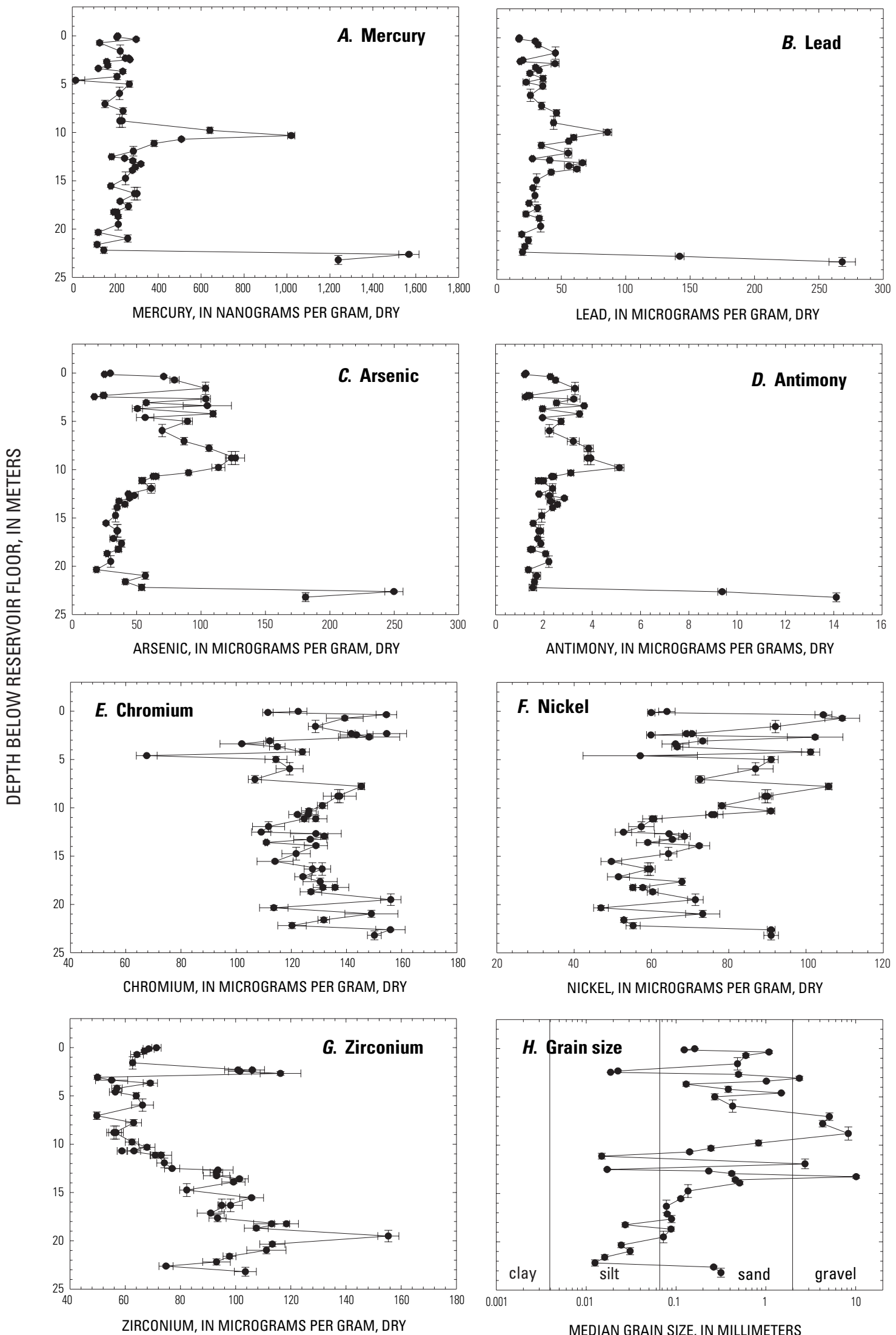

Figure 8. Deep coring profiles showing concentrations of trace metals and median grain size in sieved sediment subsamples (Y-series) from site 8 at Englebright Lake, California, May-June, 2002: $(A)$ Mercury, $(B)$ Lead, $(C)$ Arsenic, $(D)$ Antimony, $(E)$ Chromium, $(F)$ Nickel, $(G)$ Zirconium, and (H) Median grain size. Grain-size data from Snyder and others (2004b). Lines represent vertical trends of concentration values. Horizontal error bars represent standard deviation of multiple analyses. Vertical bars show depth intervals. Sieve size 0.06 millimeter. 

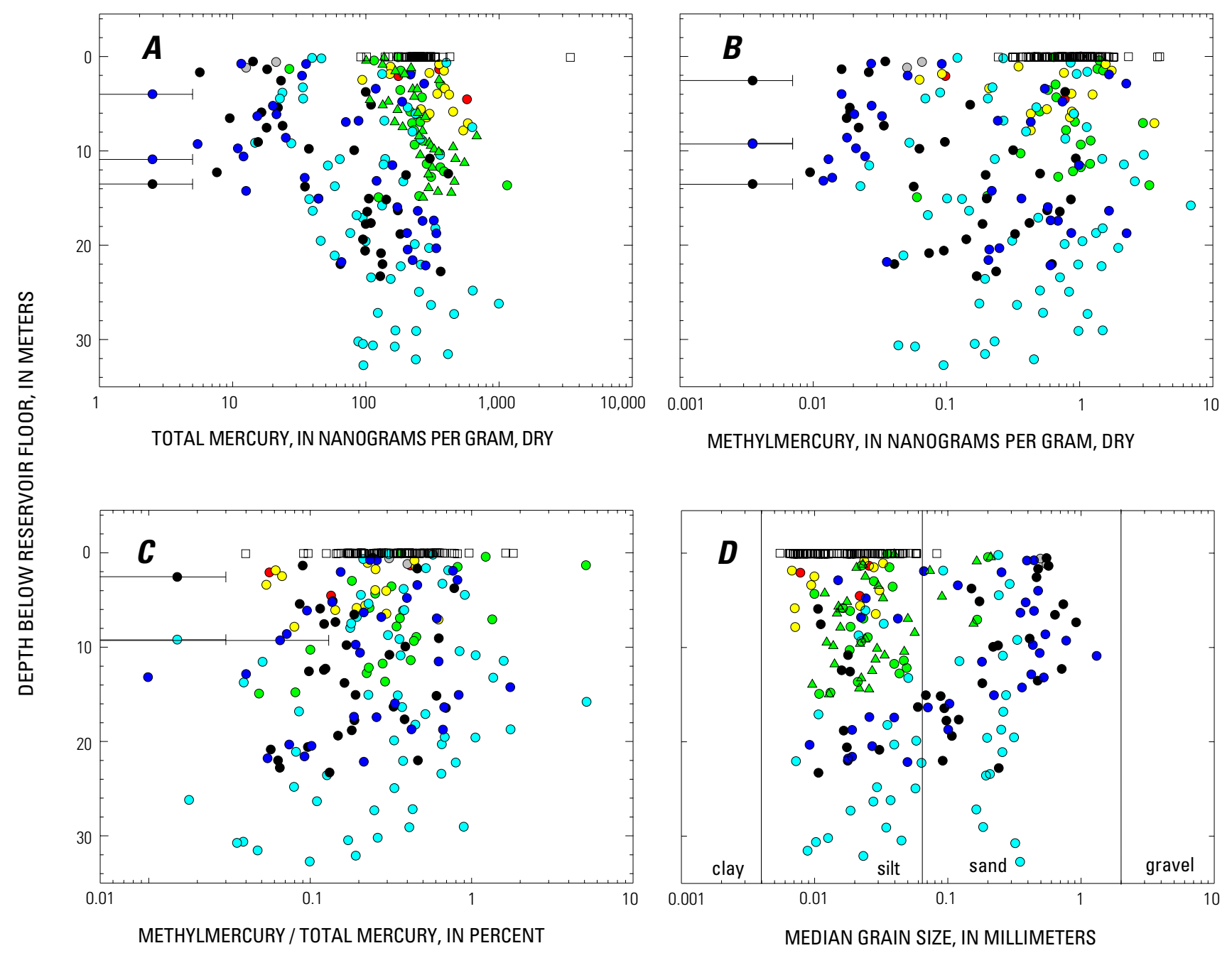

\section{EXPLANATION}

\begin{tabular}{|c|c|c|c|c|c|c|c|c|}
\hline Shallow cores: & & $\square \mathrm{Sit}$ & 10 & -19 & & & & \\
\hline \multirow{3}{*}{ Deep cores: } & downstream & 16 & 4 & 7 & 9 & 8 & 2 & upstream \\
\hline & MEM-series & - 0 & $\circ$ & o & $\bullet$ & $\bullet$ & $\circ$ & \\
\hline & Y-series & & $\Delta$ & & & & & \\
\hline
\end{tabular}

Figure 9. Plots showing relations with depth for unsieved sediment subsamples (shallow cores and selected deep cores) at Englebright Lake, California, May-June, 2002: $(A)$ Total mercury, $(B)$ Methylmercury, $(C)$ Ratio of methylmercury to total mercury, and (D) Median grain size. Results less than detection limit are indicated by a symbol at half the detection limit and an error bar from the axis to the detection limit. Vertical lines separate grain-size data into categories of clay, silt, sand, and gravel. Grain-size data from Snyder and others (2004b). 
Table 5. Statistical data showing longitudinal variation in mercury and methylmercury concentrations in sediments collected during 2002 from Englebright Lake, California.

[Replicate analyses averaged before statistical computations. SD, standard deviation; n, number of analyses. ng/g, nanogram per gram; <, less than; -, not determined]

A. Total mercury concentration

(All values in $\mathbf{n g} / \mathbf{g}$, dry)

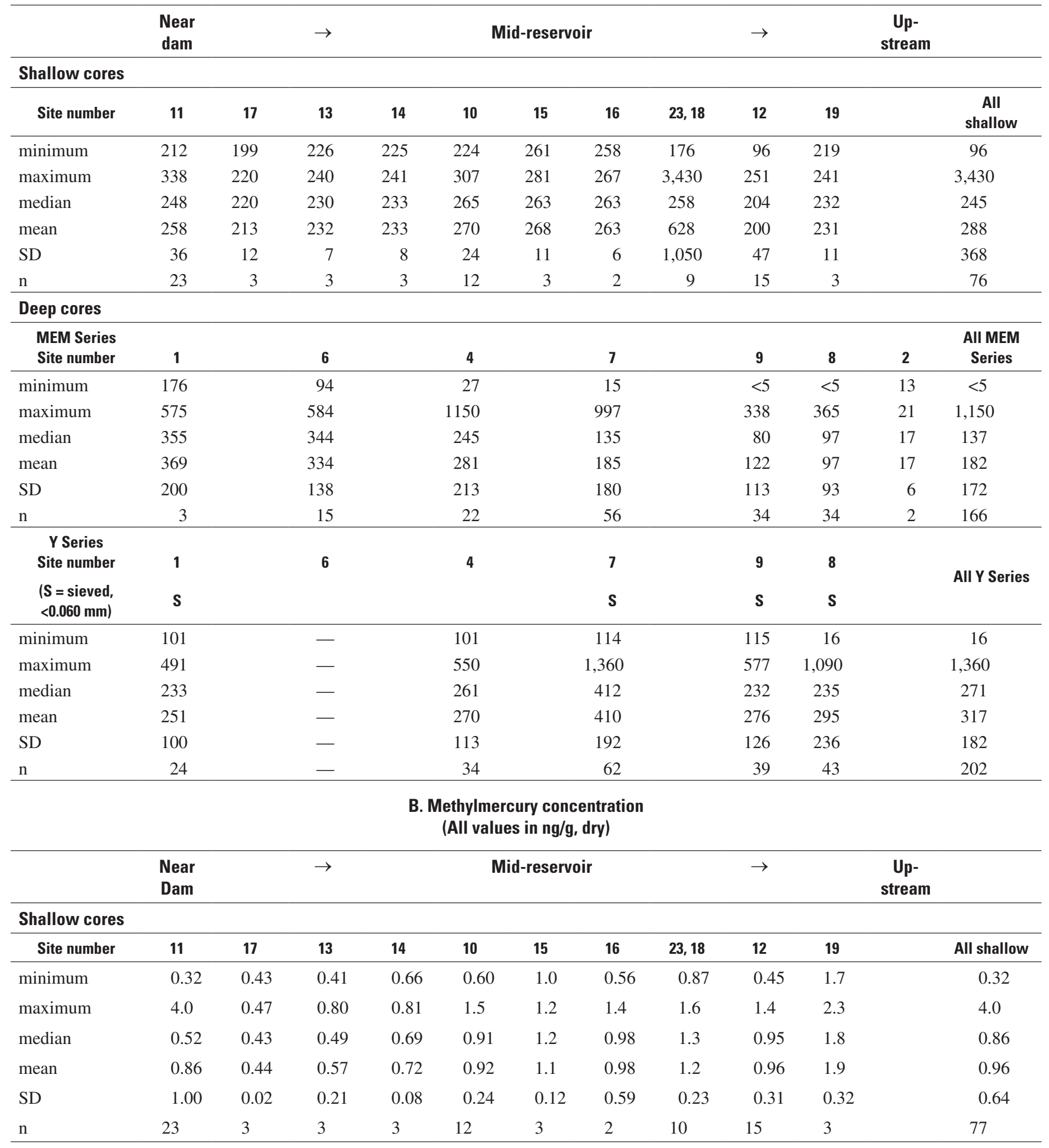


Table 5. Statistical data showing longitudinal variation in mercury and methylmercury concentrations in sediments collected during 2002 from Englebright Lake, California-Continued.

[Replicate analyses averaged before statistical computations. SD, standard deviation; n, number of analyses. ng/g, nanogram per gram; <, less than; - , not determined]

\section{B. Methylmercury concentration-Continued}

(All values in $\mathbf{n g} / \mathbf{g}$, dry)

\begin{tabular}{|c|c|c|c|c|c|c|c|c|}
\hline & $\begin{array}{l}\text { Near } \\
\text { Dam }\end{array}$ & $\rightarrow$ & \multicolumn{2}{|c|}{ Mid-reservoir } & $\rightarrow$ & \multicolumn{3}{|c|}{$\begin{array}{c}\text { Up- } \\
\text { stream }\end{array}$} \\
\hline \multicolumn{9}{|l|}{ Deep cores } \\
\hline minimum & 0.098 & 0.063 & 0.060 & $<0.007$ & $<0.007$ & $<0.007$ & 0.051 & $<0.007$ \\
\hline mean & 0.79 & 1.0 & 1.0 & 0.77 & 0.47 & 0.24 & 0.058 & 0.64 \\
\hline SD & 0.70 & 0.92 & 0.78 & 1.1 & 0.63 & 0.28 & 0.010 & 0.84 \\
\hline $\mathrm{n}$ & 3 & 15 & 22 & 56 & 34 & 34 & 2 & 166 \\
\hline
\end{tabular}

C. Ratio of methylmercury to total mercury

(All values in percent)

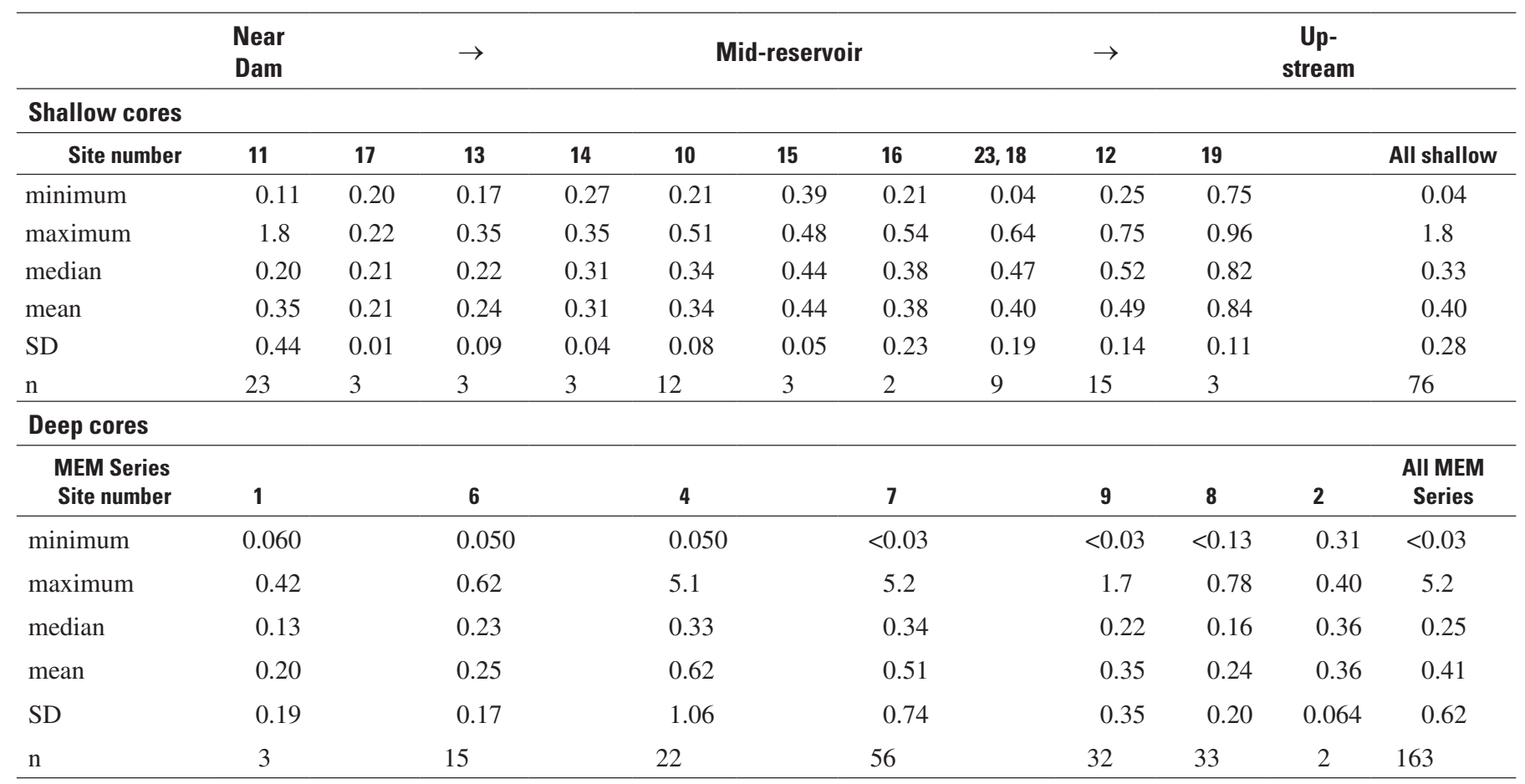


Table 6. Statistical data showing vertical variation in the mercury and methylmercury concentrations of sediments collected during 2002 from Englebright Lake, California.

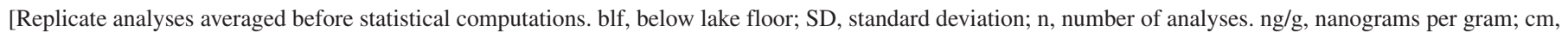
centimeter; m, meter; mm, millimeter; >, greater than. 0-4 cm (0-4), intervals exactly 0-4 cm blf; 0-4 cm (all), all intervals within 0-4 cm blf including 0-1, $1-2,0-2,2-3,3-4,2-4$, and $0-4 \mathrm{~cm}$ blf]

\section{A. Total mercury concentration}

(All values in ng/g, dry)

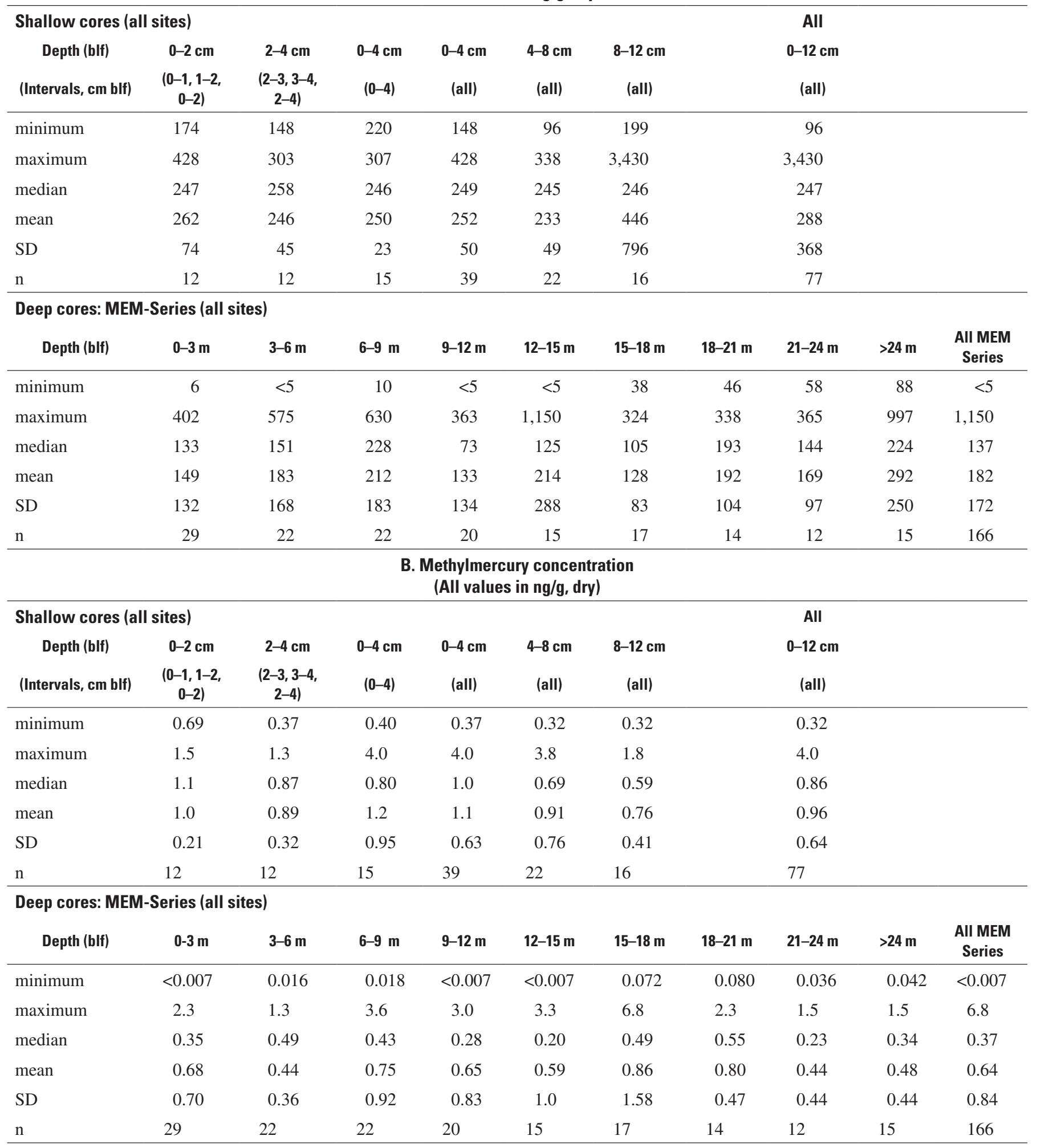


Table 6. Statistical data showing vertical variation in the mercury and methylmercury concentrations of sediments collected during 2002 from Englebright Lake, California-Continued.

[Replicate analyses averaged before statistical computations. blf, below lake floor; SD, standard deviation; n, number of analyses. ng/g, nanograms per gram; $\mathrm{cm}$, centimeter; $\mathrm{m}$, meter; $\mathrm{mm}$, millimeter; $>$, greater than. $0-4 \mathrm{~cm}(0-4)$, intervals exactly $0-4 \mathrm{~cm}$ blf; $0-4 \mathrm{~cm}$ (all), all intervals within $0-4 \mathrm{~cm}$ blf including $0-1,1-2,0-2,2-3,3-4,2-4$, and $0-4 \mathrm{~cm}$ blf]

\section{Ratio of Methylmercury to Total Mercury \\ (All values in percent)}

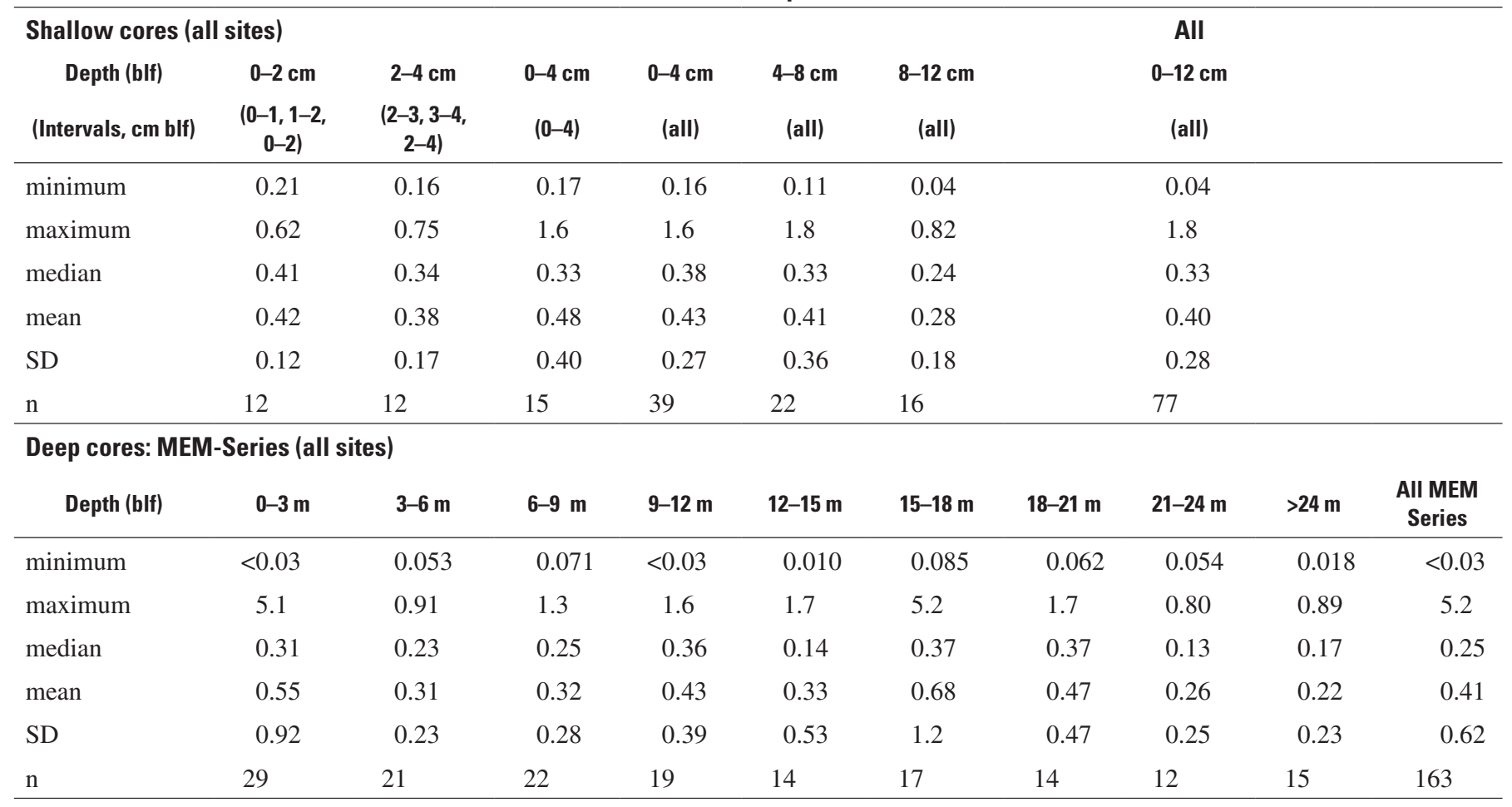


Table 7. Statistical data showing longitudinal variation in concentrations of select trace metals in sediments collected during 2002 from Englebright Lake, California.

[Replicate analyses averaged before statistical computations. S, sieved ( $<0.060$ millimeter [mm]); SD, standard deviation; $\mathrm{n}$, number of analyses. $\mu \mathrm{g} / \mathrm{g}$, microgram per gram; mm, millimeter; $<$, less than,, , not determined]

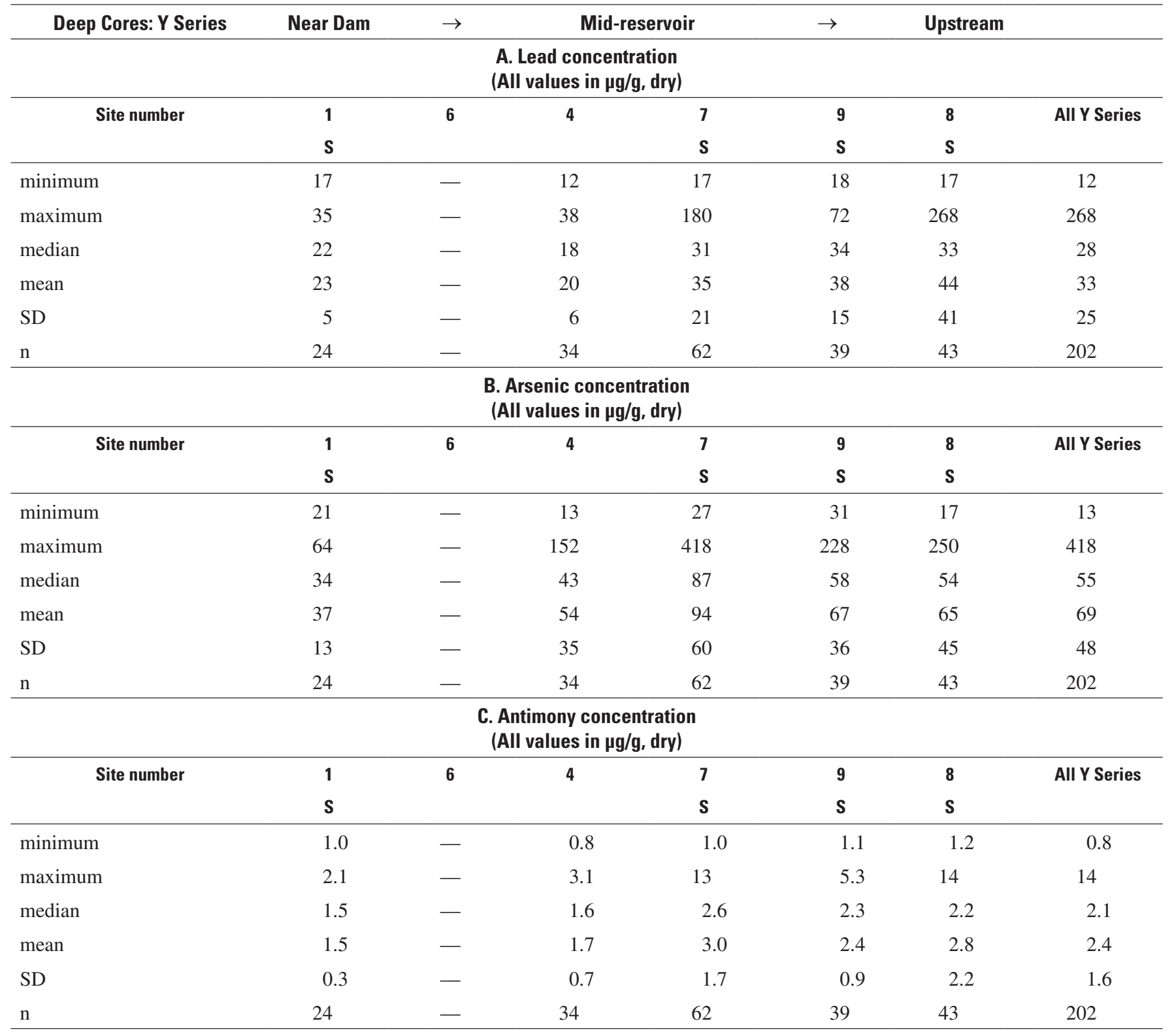


Table 7. Statistical data showing longitudinal variation in concentrations of select trace metals in sediments collected during 2002 from Englebright Lake, California-Continued.

[Replicate analyses averaged before statistical computations. S, sieved $(<0.060$ millimeter [mm]); SD, standard deviation; n, number of analyses. $\mu \mathrm{g} / \mathrm{g}$, microgram per gram; mm, millimeter; <, less than,, , not determined]

\begin{tabular}{|c|c|c|c|c|c|c|c|}
\hline Deep Cores: Y Series & Near Dam & $\rightarrow$ & \multicolumn{2}{|c|}{ Mid-reservoir } & $\rightarrow$ & \multicolumn{2}{|c|}{ Upstream } \\
\hline Site number & $\mathbf{s}$ & & & $\mathbf{S}$ & $\mathbf{S}$ & $\mathbf{S}$ & \\
\hline minimum & 125 & - & 77 & 80 & 78 & 68 & 68 \\
\hline median & 150 & - & 130 & 144 & 123 & 127 & 134 \\
\hline mean & 151 & - & 129 & 142 & 123 & 127 & 134 \\
\hline SD & 19 & - & 24 & 23 & 21 & 17 & 23 \\
\hline $\mathrm{n}$ & 24 & - & 34 & 62 & 39 & 43 & 202 \\
\hline minimum & 51 & - & 52 & 49 & 52 & 47 & 47 \\
\hline maximum & 152 & - & 135 & 149 & 112 & 109 & 152 \\
\hline median & 97 & - & 87 & 100 & 78 & 68 & 87 \\
\hline mean & 99 & - & 87 & 101 & 77 & 72 & 87 \\
\hline SD & 26 & - & 20 & 24 & 17 & 17 & 24 \\
\hline $\mathrm{n}$ & 24 & - & 34 & 62 & 39 & 43 & 202 \\
\hline \multicolumn{8}{|c|}{$\begin{array}{l}\text { F. Zirconium concentration } \\
\text { (All values in } \mu \mathrm{g} / \mathrm{g} \text {, dry) }\end{array}$} \\
\hline $\mathrm{SD}$ & 7 & - & 11 & 11 & 22 & 23 & 18 \\
\hline $\mathrm{n}$ & 24 & - & 34 & 62 & 39 & 43 & 202 \\
\hline
\end{tabular}


Subsamples from shallow box cores taken at ten sampling sites in Englebright Lake (figs. 2, 3) were analyzed for $\mathrm{Hg}_{\mathrm{T}}$ and $\mathrm{MeHg}$ (table 4). Variations in the spatial distribution of $\mathrm{Hg}_{\mathrm{T}}, \mathrm{MeHg}$, and $\mathrm{MeHg} / \mathrm{Hg}_{\mathrm{T}}$ in subsamples from shallow and deep cores are summarized in tables 5 (longitudinal variation, along the long axis of the reservoir) and 6 (vertical variation). The columns in table 5 are arranged in upstream order from left to right. Median values of $\mathrm{Hg}_{\mathrm{T}}$ in shallow box cores from all ten sites ranged from 204 to $265 \mathrm{ng} / \mathrm{g}$, and all but one standard deviation was relatively small, indicating that nearly all concentration values were in the range of 200 to $300 \mathrm{ng} / \mathrm{g}$. Median values of $\mathrm{Hg}_{\mathrm{T}}$ in the MEM-series showed considerable longitudinal variation; highest median values were for sites 1 and 6 near the dam (355 and $344 \mathrm{ng} / \mathrm{g}$, respectively); lowest median values were for the three most upstream sites $(80,97$, and $17 \mathrm{ng} / \mathrm{g}$ for sites 9,8 , and 2, respectively); intermediate values were for the mid-reservoir sites (245 and $135 \mathrm{ng} / \mathrm{g}$ for sites 4 and 7 , respectively). The longitudinal trend in median $\mathrm{Hg}_{\mathrm{T}}$ concentration of unsieved subsamples from the deep cores follows the trend in median grain size; $\mathrm{Hg}_{\mathrm{T}}$ concentrations increase as median grain size gets finer toward the dam (Snyder and others, 2004c).

Interpreting total mercury concentration in the Y-series subsamples will be complicated by the fact that only the fines (silt-clay) fraction was analyzed in profiles $1 \mathrm{Y}, 7 \mathrm{Y}, 8 \mathrm{Y}$, and $9 \mathrm{Y}$, whereas the whole sediment was analyzed in profile $4 \mathrm{Y}$. The sieved material in profiles $7 \mathrm{Y}, 8 \mathrm{Y}$, and $9 \mathrm{Y}$ had higher median concentrations of $\mathrm{Hg}_{\mathrm{T}}(232-412 \mathrm{ng} / \mathrm{g})$ than unsieved subsamples (MEM-series) from the same sites (80-135 ng/g) (table 5). The unsieved subsamples from profile $4 \mathrm{Y}$ had a median concentration of $\mathrm{Hg}_{\mathrm{T}}(261 \mathrm{ng} / \mathrm{g})$ which is comparable to the median value for MEM-series subsamples from this location $(245 \mathrm{ng} / \mathrm{g})$.

Methylmercury concentrations in shallow cores ranged from 0.32 to $4.0 \mathrm{ng} / \mathrm{g}$; the median value was $0.86 \mathrm{ng} / \mathrm{g}$. Median $\mathrm{MeHg}$ concentrations were low in box cores from the three sites nearest to Englebright Dam (sites 11, 17 and 13; 0.43 to $0.52 \mathrm{ng} / \mathrm{g}$ ) compared with those for sites in the mid-reservoir and upstream areas $(0.69$ to $1.8 \mathrm{ng} / \mathrm{g})$. In contrast, median $\mathrm{MeHg}$ concentrations in subsamples from the deep cores (MEM-series) were higher at sites near the dam (sites 1, 6 and 4; 0.76 to $0.90 \mathrm{ng} / \mathrm{g}$ ) than at the mid-reservoir and upstream locations (sites 7, 9, 8, and 2; 0.058 to $0.43 \mathrm{ng} / \mathrm{g}$ ).

The ratio $\mathrm{MeHg} / \mathrm{Hg}_{\mathrm{T}}$ (expressed as a percentage of $\mathrm{Hg}_{\mathrm{T}}$ ) showed some similarity in the trends of longitudinal variation among shallow and deep subsamples (table 5). Lowest median values of $\mathrm{MeHg} / \mathrm{Hg}_{\mathrm{T}}$ were for the site closest to the dam for both the shallow cores (site 11; 0.20 percent) and the deep cores ( $\mathrm{MeHg} / \mathrm{Hg}_{\mathrm{T}}$ were for shallow cores at the mid-reservoir and upstream sites ( 0.31 to 0.82 percent), and for deep cores at two mid-reservoir sites ( 0.33 and 0.34 percent $)$ and the most upstream site ( 0.36 percent). However, the upstream sites were not uniformly high in values of $\mathrm{MeHg} / \mathrm{Hg}_{\mathrm{T}}$ in the deep cores, as sites 9 and 8 had median values of 0.22 and 0.16 percent, respectively.
The spatial variability of $\mathrm{Hg}_{\mathrm{T}}, \mathrm{MeHg}$, and $\mathrm{MeHg} / \mathrm{Hg}_{\mathrm{T}}$ as a function of depth in the cores is summarized in table 6 . There was little vertical variation in $\mathrm{Hg}_{\mathrm{T}}$ within the top $12 \mathrm{~cm}$ sampled by the shallow cores, similar to the lack of longitudinal variation. In the deeper cores, vertical trends in the concentration of $\mathrm{Hg}_{\mathrm{T}}$ were more apparent in the individual profiles (figs. 4A-8A) compared with the summary statistics based on absolute depth (table 6 ) because of the varying thickness of the bed sediments along the longitudinal axis of the reservoir. An analysis of reservoir stratigraphy using ${ }^{137} \mathrm{Cs}$ dating (Snyder and others, in press) is providing additional insights into temporal variations in the deposition of $\mathrm{Hg}$ and other trace metals. The highest median concentration of $\mathrm{MeHg}$ was in the top 2 centimeters of the shallow box cores. Median concentrations of $\mathrm{MeHg}$ and median values of $\mathrm{MeHg} / \mathrm{Hg}_{\mathrm{T}}$ decreased with depth from $0-4$ to $4-8 \mathrm{~cm}$, and from $4-8$ to $8-12 \mathrm{~cm}$ in the shallow cores (table 6 ). However, similar decreases were not systematic on a larger scale in the deep cores of the MEM series. The overall median of $\mathrm{MeHg} / \mathrm{Hg}_{\mathrm{T}}$ in the deep cores was 0.25 percent, not much less than the overall median value for the shallow cores ( 0.33 percent). The persistence of $\mathrm{MeHg}$ at depth in the sediments of Englebright Lake at median concentrations of 0.20 to $0.55 \mathrm{ng} / \mathrm{g}$ indicates either preservation of $\mathrm{MeHg}$ after burial and (or) an ongoing balance between rates of $\mathrm{Hg}$ methylation and $\mathrm{MeHg}$ demethylation in the subsurface.

\section{Trace and Major Elements}

Chemical analyses of trace and major elements in Y-series subsamples (table B5) provide information on the sediment geochemistry at five locations in Englebright Lake. Depth profiles of lead, arsenic, antimony, chromium, nickel, and zirconium were plotted in figures $4 B-G$ through $8 B-G$. An interpretation of these profiles in terms of the depositional history of Englebright Lake sediments will be published separately; therefore only a few features of the spatial distribution of trace elements are described here. Longitudinal variations in the silt and clay fraction of select trace metals from sites 1 , 7,9 , and 8 were evaluated using statistical data compiled in table 7 and the plots in figures 4, 6, 7, and 8. (Data from site 4 were not used in this comparison because the subsamples were not sieved prior to analysis.)

Lead concentrations in subsamples from site 1 (near Englebright Dam) had a mean concentration of $23 \mu \mathrm{g} / \mathrm{g}$ and a standard deviation of $5 \mu \mathrm{g} / \mathrm{g}$, and ranged from a minimum of $17 \mu \mathrm{g} / \mathrm{g}$ to a maximum of $35 \mu \mathrm{g} / \mathrm{g}$. In contrast, lead concentrations at the three upstream sites (7, 9, and 8) had mean values of 35 to $44 \mu \mathrm{g} / \mathrm{g}$ and much higher maximum values (72 to $268 \mu \mathrm{g} / \mathrm{g}$ ). The maximum lead values at the three upstream sites were from the deepest interval in each of the profiles. Median lead concentrations at the three upstream sites (31 to $34 \mu \mathrm{g} / \mathrm{g}$ ) were also higher than the median value at site 1 $(22 \mu \mathrm{g} / \mathrm{g})$. 
The longitudinal variation of arsenic and antimony concentrations in the silt-clay fraction was similar to that of lead, in that concentrations were lower in subsamples from the site nearest the dam (site 1) compared with the three upstream locations (sites 7, 9, and 8; table 7). The mean value of arsenic concentration at site 1 was $37 \mu \mathrm{g} / \mathrm{g}$ with a standard deviation of $13 \mu \mathrm{g} / \mathrm{g}$ and a maximum value of $64 \mu \mathrm{g} / \mathrm{g}$. In contrast, the mean arsenic concentrations in subsamples from the three upper locations ranged from 65 to $94 \mu \mathrm{g} / \mathrm{g}$. Several subsamples from sites 7, 9, and 8 had arsenic concentrations greater than $100 \mu \mathrm{g} / \mathrm{g}$. The mean antimony concentration at site 1 was $1.5 \mu \mathrm{g} / \mathrm{g}$ with a standard deviation of $0.3 \mu \mathrm{g} / \mathrm{g}$. At the three upstream sites, the mean antimony values ranged from 2.4 to $3.0 \mu \mathrm{g} / \mathrm{g}$. Like lead, maximum arsenic and antimony concentrations were in the deepest subsamples from each of the three upstream locations.

Longitudinal trends in concentrations of chromium and nickel are opposite those described for lead, arsenic, and antimony, in that the concentrations at the two sites located farthest upstream (sites 9 and 8) are generally lower than those from the two sites located relatively downstream (sites 1 and 7 ; table 7). Mean values ( \pm standard deviation, SD) of chromium concentration were $151 \pm 19 \mu \mathrm{g} / \mathrm{g}$ and $142 \pm 23 \mu \mathrm{g} / \mathrm{g}$ at relatively downstream sites 1 and 7, respectively, whereas the mean values $( \pm \mathrm{SD})$ were $123 \pm 21$ and $127 \pm 17 \mu \mathrm{g} / \mathrm{g}$ at the relatively upstream sites 9 and 8, respectively. Maximum values of chromium were also higher at sites 1 and 7 (196 and $184 \mathrm{ug} / \mathrm{g}$ respectively) compared with those for sites 9 and 8 (164 and $156 \mu \mathrm{g} / \mathrm{g}$, respectively). Nickel concentrations followed a trend similar to that for chromium; mean values $( \pm \mathrm{SD})$ at the upstream locations (sites 9 and 8 ) were $77 \pm$ $17 \mu \mathrm{g} / \mathrm{g}$ and $72 \pm 17 \mu \mathrm{g} / \mathrm{g}$, respectively, compared with values from the downstream locations (sites 1 and 7) of $99 \pm 26 \mu \mathrm{g} / \mathrm{g}$ and $101 \pm 24 \mu \mathrm{g} / \mathrm{g}$, respectively. Maximum concentrations of nickel were 112 and $109 \mu \mathrm{g} / \mathrm{g}$ at sites 9 and 8, respectively, compared with 152 and $149 \mu \mathrm{g} / \mathrm{g}$ at sites 1 and 7, respectively. The maximum concentrations of chromium and nickel were not located in the deepest intervals of sites 7, 9 and 8, in contrast to lead, arsenic, and antimony (figs. 6-8).

Mean concentrations of zirconium were in the relatively narrow range of 78 to $83 \mu \mathrm{g} / \mathrm{g}$ at the four reservoir sites $(1,7$, 9 , and 8) where the silt-clay fraction was analyzed. Maximum values of zirconium concentration generally were in samples having relatively small median grain size. The maximum concentrations of zirconium at the upstream locations (sites 9 and
8) were 120 and $155 \mathrm{ug} / \mathrm{g}$, respectively, whereas maximum concentrations at the more downstream locations were lower (98 and $96 \mathrm{ug} / \mathrm{g}$ at sites 1 and 7, respectively). Zirconium occurs primarily in the mineral zircon $\left(\mathrm{ZrSiO}_{3}\right)$, which tends to be silt-sized.

\section{Mercury Methylation Potential}

Results from radiotracer measurements of ${ }^{203} \mathrm{Hg}$ (II)methylation potential rates for shallow and deep sediments from Englebright Lake are shown in table 8 and figure 10. Potential rates of microbial $\mathrm{MeHg}$ production in shallow sediments averaged about one percent per day (percent/d), whereas in deeper sediments, the rate was less than detection $(0.01$ percent $/ \mathrm{d})$ in five of six samples and 0.08 percent/d in the other. Shallow sediments also had higher average values of weight loss on ignition (a proxy for organic content) and porosity, significantly higher concentrations of most solidphase Fe species, and lower dry weight (equivalent to a higher moisture content) than deeper sediments (table 9).

Sulfate reduction (SR) is the microbial process thought to be most responsible for $\mathrm{Hg}$ methylation in anoxic sediments (Gilmour and others, 1992), although iron-reducing bacteria may play a role in some environmental settings, such as Clear Lake, California (Fleming and others, 2006). The presence of active microbial SR in the shallow sediments (table 9), along with the high Hg-methylation rates in this zone (table 8), support this generally held view. Although we did not measure SR rates in deep sediments, very low $\mathrm{Hg}$-methylation rates observed in the deep cores would be consistent with low rates of SR. Below a depth of 10-50 cm in freshwater systems, it is quite common for SR to become limited as pore-water sulfate, the primary electron acceptor for this process, becomes depleted. The low measured concentrations of amorphous Fe(III) (table 9), needed to fuel microbial Fe(III)-reduction, indicates that important electron acceptors needed to drive anaerobic microbial processes are limiting in deeper sediments of Englebright Lake. Loss on ignition values were higher in shallow sediments than deeper sediments at two of the three sites (deep sites 4 and 9 corresponding to shallow sites 10 and 12 , respectively); data for the third site (deep site 1 corresponding to shallow site 11) are equivocal (table 9). 
Table 8. Whole-sediment ${ }^{203} \mathrm{Hg}$ (II)-methylation rate constants and calculated potential rates for shallow and deep sediments (MP series) from Englebright Lake, California, 2002.

[Each value for rate constant and potential rate (in bold) represents the mean of two incubated samples (kill corrected); absolute deviation for each measurement given in parentheses. ${ }^{203} \mathrm{Hg}(\mathrm{II})$, mercury-203 radiotracer divalent inorganic mercury; SD, standard deviation. cm, centimeter; \%/d, percent per day; ng/g dry sed/d, nanogram per gram dry sediment per day; <, less than detection limit. ${ }^{203} \mathrm{Hg}$-kmeth or kmeth, whole-sediment ${ }^{203} \mathrm{Hg}(\mathrm{II})$-methylation rate constant expressed as percentage of ${ }^{203} \mathrm{Hg}$ (II) converted to $\mathrm{CH}_{3}{ }^{203} \mathrm{Hg}$ per day, calculated as $\left[{ }^{203} \mathrm{Hg}-\mathrm{kmeth}=\ln (1-\mathrm{fm}) / \mathrm{t} \cdot 100\right]$; fm, fraction of added ${ }^{203} \mathrm{Hg}$ (II) converted to $\mathrm{CH}_{3}{ }^{203} \mathrm{Hg}$; t , incubation time. Whole-sediment ${ }^{203} \mathrm{Hg}$ (II)-methylation potential (MP) rate calculated as $\mathrm{MP}={ }^{203} \mathrm{Hgds}-{ }^{203} \mathrm{Hgds} \cdot \mathrm{e}^{\wedge}(-\mathrm{kmeth} \cdot \mathrm{t}) ;{ }^{203} \mathrm{Hgds}$, concentration of radiotracer ${ }^{203} \mathrm{Hg}$ (II) per gram dry sediment]

\begin{tabular}{|c|c|c|c|c|c|}
\hline \multirow[t]{2}{*}{ Site } & \multirow{2}{*}{$\begin{array}{l}\text { Depth } \\
\text { interval } \\
\text { (cm) }\end{array}$} & \multicolumn{2}{|c|}{$\begin{array}{c}\text { Whole-sediment } \\
{ }^{203} \mathrm{Hg}(\mathrm{II})-\text { methylation rate constant, } \\
{ }^{203} \mathrm{Hg}-\mathrm{kmeth} \\
(\% / \mathrm{d})\end{array}$} & \multicolumn{2}{|c|}{$\begin{array}{l}\text { Whole-sediment } \\
{ }^{203} \mathrm{Hg} \text { (II)-methylation potential rate } \\
\text { (ng/g dry sed/d) }\end{array}$} \\
\hline & & $\begin{array}{l}\text { Kill-corrected } \\
\text { average }\end{array}$ & $\begin{array}{l}\text { Absolute } \\
\text { deviation }\end{array}$ & $\begin{array}{l}\text { Kill-corrected } \\
\text { average }\end{array}$ & $\begin{array}{l}\text { Absolute } \\
\text { deviation }\end{array}$ \\
\hline \multicolumn{6}{|c|}{ Shallow core samples } \\
\hline 11 & $0-4$ & 0.55 & $(0.45)$ & 6.2 & $(5.1)$ \\
\hline 11 & $4-8$ & 0.48 & $(0.01)$ & 5.0 & $(0.1)$ \\
\hline 10 & $0-4$ & 2.16 & $(0.12)$ & 30.4 & (1.6) \\
\hline 10 & $4-8$ & 1.04 & $(0.48)$ & 11.5 & (5.3) \\
\hline \multirow[t]{3}{*}{12} & $0-4$ & 1.17 & $(0.32)$ & 10.3 & $(2.8)$ \\
\hline & mean & 1.08 & & 12.66 & \\
\hline & SD & 0.67 & & 10.27 & \\
\hline \multicolumn{6}{|c|}{ Deep core samples } \\
\hline 1 & $244-267$ & 0.08 & $(0.05)$ & 0.19 & $(0.12)$ \\
\hline 1 & $573-625$ & $<0.01$ & & $<0.02$ & \\
\hline 4 & $673-726$ & $<0.01$ & & $<0.01$ & \\
\hline 4 & $1,515-1,595$ & $<0.01$ & & $<0.02$ & \\
\hline 9 & $1,179-1,292$ & $<0.01$ & & $<0.01$ & \\
\hline \multirow[t]{3}{*}{9} & $2,439-2,486$ & $<0.01$ & & $<0.01$ & \\
\hline & mean & $<0.02$ & & $<0.04$ & \\
\hline & SD & - & & - & \\
\hline
\end{tabular}




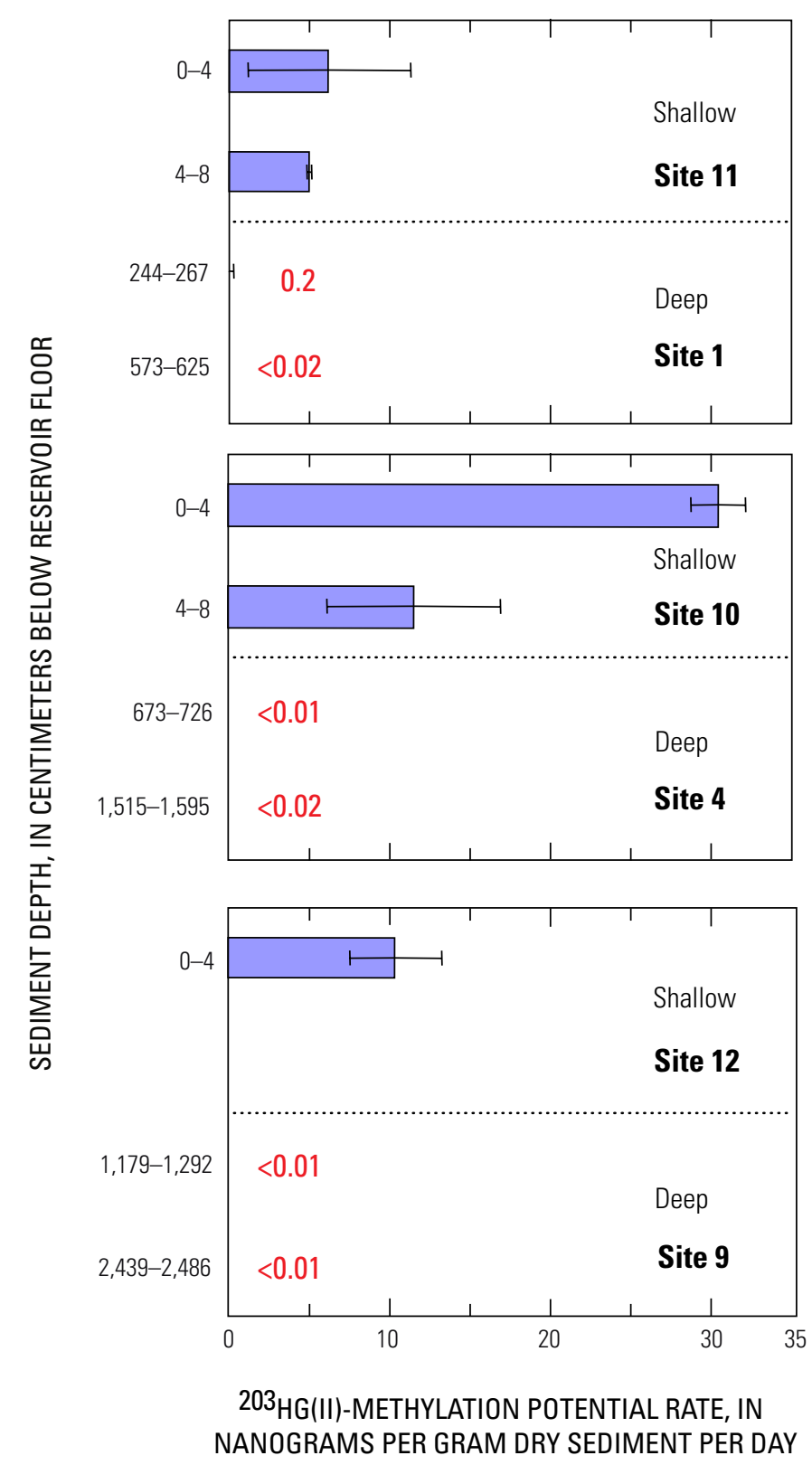

Figure 10. Plots showing ${ }^{203} \mathrm{Hg}(\mathrm{II})$-methylation potential rate as a function of depth for sediments from Englebright Lake, California, 2002: $(A)$ Sites 1 and 11, $(B)$ Sites 4 and 10, (C) Sites 9 and 12.

Bar represents average of two observations. Error bars indicate absolute deviation. 


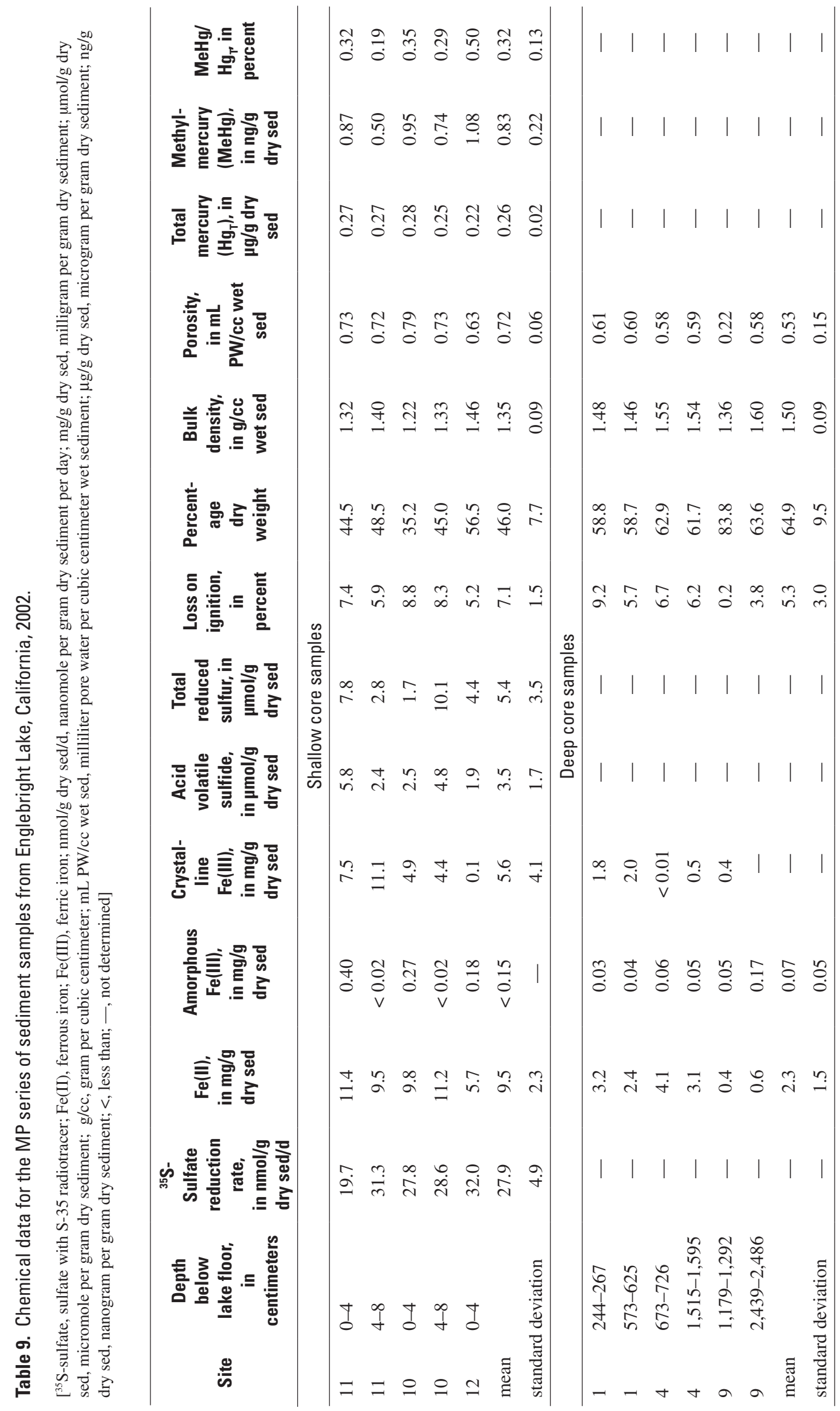


Comparing shallow (0-4 cm depth) sediment Hg-transformation dynamics among sites 10-12 (table 8 and fig. 10), the mid-reservoir site (10) had the highest rate of $\mathrm{MeHg}$ production, whereas the site closest to the dam (site 11) had the lowest, lower than the highest site by a factor of about five. For the two shallow sites (10 and 11) where two depth intervals $(0-4 \mathrm{~cm}$ and $4-8 \mathrm{~cm})$ were sampled, the highest rates of $\mathrm{MeHg}$ production occurred in the $0-4 \mathrm{~cm}$ layer, by factors of 1.2 and 2.6 relative to the $4-8 \mathrm{~cm}$ interval at the two sites, respectively. Comparing these $\mathrm{Hg}$-transformation rates with the other measured parameters suggests that $\mathrm{MeHg}$ production was negatively correlated with redox potential and positively correlated with sediment $\mathrm{pH}$ (fig. 11). Further, the ratio of methylmercury to total mercury $\left(\mathrm{MeHg} / \mathrm{Hg}_{\mathrm{T}}\right)$, which has been used as a proxy for the relative activity of $\mathrm{MeHg}$ production, appeared to be negatively correlated with concentrations of crystalline $\mathrm{Fe}(\mathrm{III})$ in sediment, ferrous iron (Fe(II)) in pore water, and DOC in pore water (fig. 12). However, the small number of samples $(n=5)$ caused the trends associated with $\mathrm{MeHg}$ production (fig. 11) and $\mathrm{MeHg} / \mathrm{Hg}_{\mathrm{T}}$ (fig. 12) to be somewhat tenuous. Also, because of covariation among these and other ancillary sediment parameters (for example, concentrations of crystalline iron(III) in sediment, iron(II) in pore water, and dissolved organic carbon in pore water; tables 9, 10; fig. 12), it is difficult to separate out which factors ultimately control $\mathrm{Hg}$ methylation in this system based on the current limited number of shallow sediment observations $(n=5)$.

The trend towards low rates of $\mathrm{Hg}$ methylation in deep sediments observed in the current study parallels earlier results from Daguerre Point Dam, located on the lower Yuba River (12 km downstream of Englebright Dam), where similarly low $\mathrm{MeHg}$ production rates were measured in cores ranging from 0.6 to $9.1 \mathrm{~m}$ below the river bed (Hunerlach and others, 2004). No shallow sediments were taken from Daguerre Point Dam for comparison with those analyzed in the current study. However, $\mathrm{MeHg}$ production rates for shallow sediment $(0-4 \mathrm{~cm})$ samples collected from the Yuba River upstream $(n=3)$ and downstream $(n=3)$ of Daguerre Point Dam were, on average, about 1/50th of the rates for samples collected from shallow sediments in Englebright Lake. The primary differences between shallow sediments collected within Englebright Lake and shallow sediments collected in the lower Yuba River were that the former (a) had more organic material, (b) had higher rates of $\mathrm{SR}$, and (c) were more reduced than the latter.

\section{Heavy Minerals}

Particle-size distribution was determined for nine composite samples that were used to evaluate gold concentration and to observe heavy minerals microscopically (table C1). Heavy mineral concentrates prepared from these composite samples provided an opportunity to observe grains of gold, amalgam, and other heavy minerals such as iron sulfides. A photograph of heavy minerals from sample 5A is shown in figure 13. A series of SEM photomicrographs showing gold and amalgam textures from the heavy mineral concentrates is given in Appendix D (figs. D1-D16). The particle-size distribution and gold tenor (a mining term for concentration) were determined for the heavy mineral concentrates prepared from these composite samples (table C2). The spatial distribution of the gold tenor results was plotted on a longitudinal section of the reservoir (fig. 14). The highest values of gold tenor were for the four samples from sites 2 and 5/7; these values ranged from 270 to 840 milligrams of gold per cubic meter $\left(\mathrm{mg} \mathrm{Au} / \mathrm{m}^{3}\right)$. The median value of gold tenor for the nine composite samples was $92 \mathrm{mg} \mathrm{Au} / \mathrm{m}^{3}$. For comparison, the average gold tenor for major hydraulic placer mines in the Sierra Nevada was $189 \mathrm{mg} \mathrm{Au} / \mathrm{m}^{3}$ (Yeend, 1974).

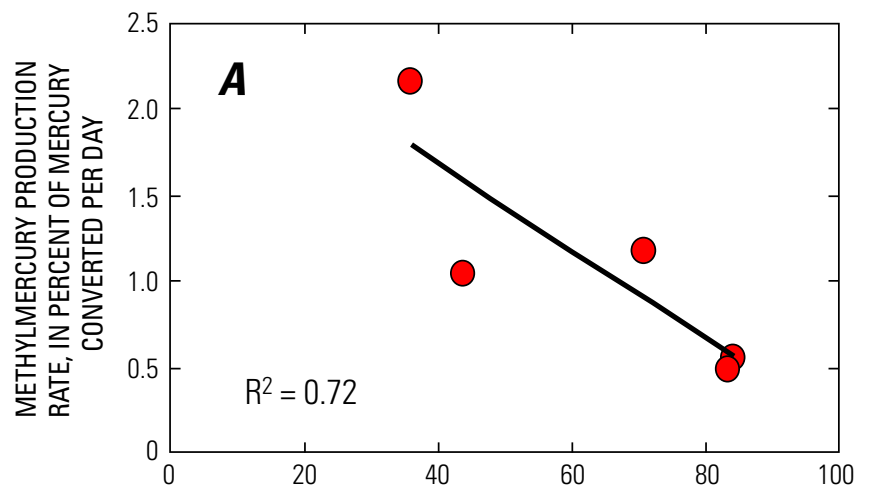

Eh (OXIDATION-REDUCTION POTENTIAL), IN MILLIVOLTS

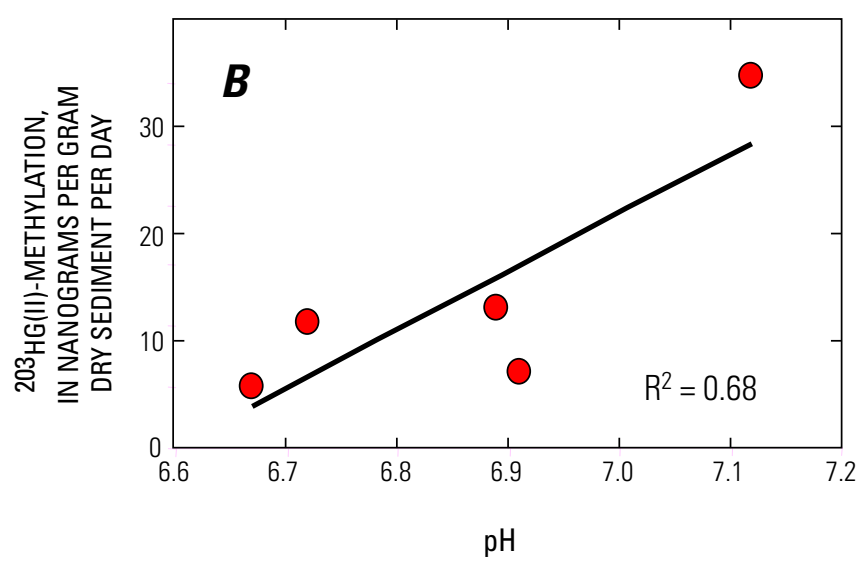

Figure 11. Plots showing correlation of the ${ }^{203} \mathrm{Hg}(\mathrm{II})$-methylation potential rate for shallow sediments from Englebright Lake, California, 2002: $(A)$ Redox potential, $(B) \mathrm{pH}$. Redox, reduction-oxidation; $\mathrm{R}^{2}$, coefficient of determination for linear least-squares regression. 


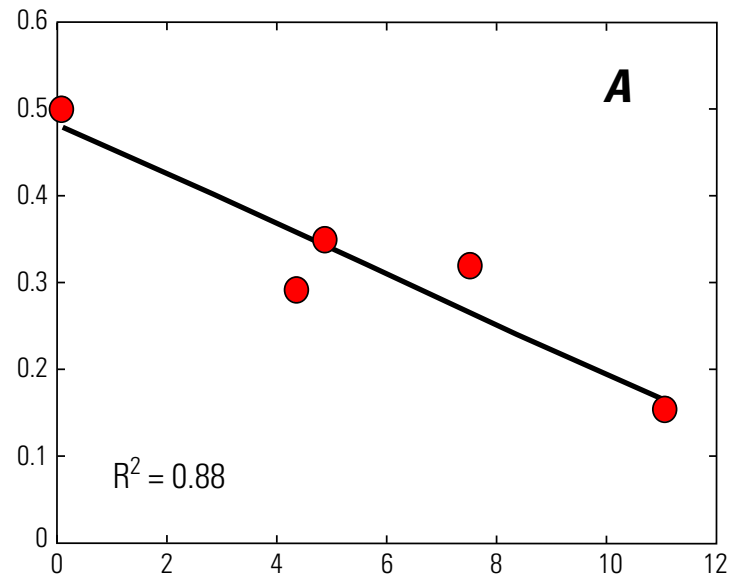

CRYSTALLINE IRON (III), IN MILLIGRAMS PER GRAM (DRY)

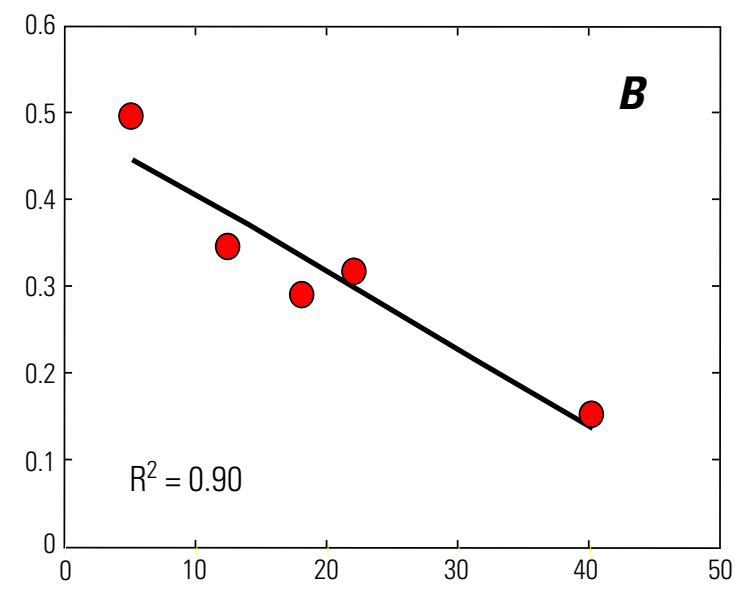

IRON (II), IN MILLIGRAMS PER LITER

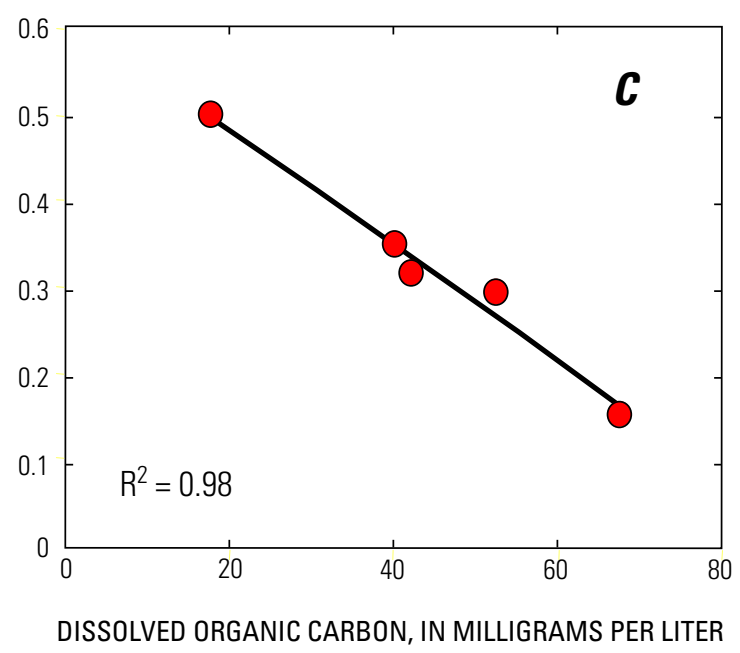

Figure 12. Plots showing correlation of the ratio of methylmercury to total mercury with forms of iron and carbon in shallow sediments from Englebright Lake, California, 2002. (A) Concentration of crystalline iron (III) in sediment, (B) Concentration of iron (II) in pore water, $(C)$ Concentration of dissolved organic carbon in pore water. $\mathrm{R}^{2}$, coefficient of determination for linear least-squares regression. 
Table 10. Chemical data for pore water from the MP series of sediment samples from Englebright Lake, California, 2002.

[Fe(II), ferrous iron. Deep core samples were not analyzed]

\begin{tabular}{|c|c|c|c|c|c|c|c|}
\hline Site & $\begin{array}{l}\text { Depth below } \\
\text { lake floor, } \\
\text { in centimeters }\end{array}$ & $\begin{array}{c}\text { Sulfate, } \\
\text { in micromoles } \\
\text { per liter }\end{array}$ & $\begin{array}{c}\text { Chloride, } \\
\text { in micromoles } \\
\text { per liter }\end{array}$ & $\begin{array}{c}\text { Fe(II), } \\
\text { in milligrams } \\
\text { per liter }\end{array}$ & $\begin{array}{c}\text { Dissolved } \\
\text { organic } \\
\text { carbon, } \\
\text { in milligrams } \\
\text { per liter }\end{array}$ & $\mathrm{pH}$ & $\begin{array}{c}\text { Oxidation- } \\
\text { reduction } \\
\text { potential, Eh, } \\
\text { in millivolts }\end{array}$ \\
\hline \multicolumn{8}{|c|}{ Shallow core samples } \\
\hline 11 & $0-4$ & 18.4 & 0.3 & 22.0 & 42.3 & 6.91 & 84 \\
\hline 11 & $4-8$ & 21.7 & 0.3 & 40.1 & 67.7 & 6.67 & 83 \\
\hline 10 & $0-4$ & 31.3 & 0.3 & 12.5 & 40.2 & 7.12 & 36 \\
\hline 10 & $4-8$ & 9.9 & 0.1 & 18.1 & 52.6 & 6.89 & 44 \\
\hline 12 & $0-4$ & 33.4 & 0.4 & 5.1 & 18.2 & 6.72 & 71 \\
\hline \multicolumn{2}{|l|}{ mean } & 22.9 & 0.3 & 19.6 & 44.2 & 6.86 & 64 \\
\hline \multicolumn{2}{|c|}{ standard deviation } & 9.6 & 0.1 & 13.1 & 18.2 & 0.18 & 23 \\
\hline
\end{tabular}

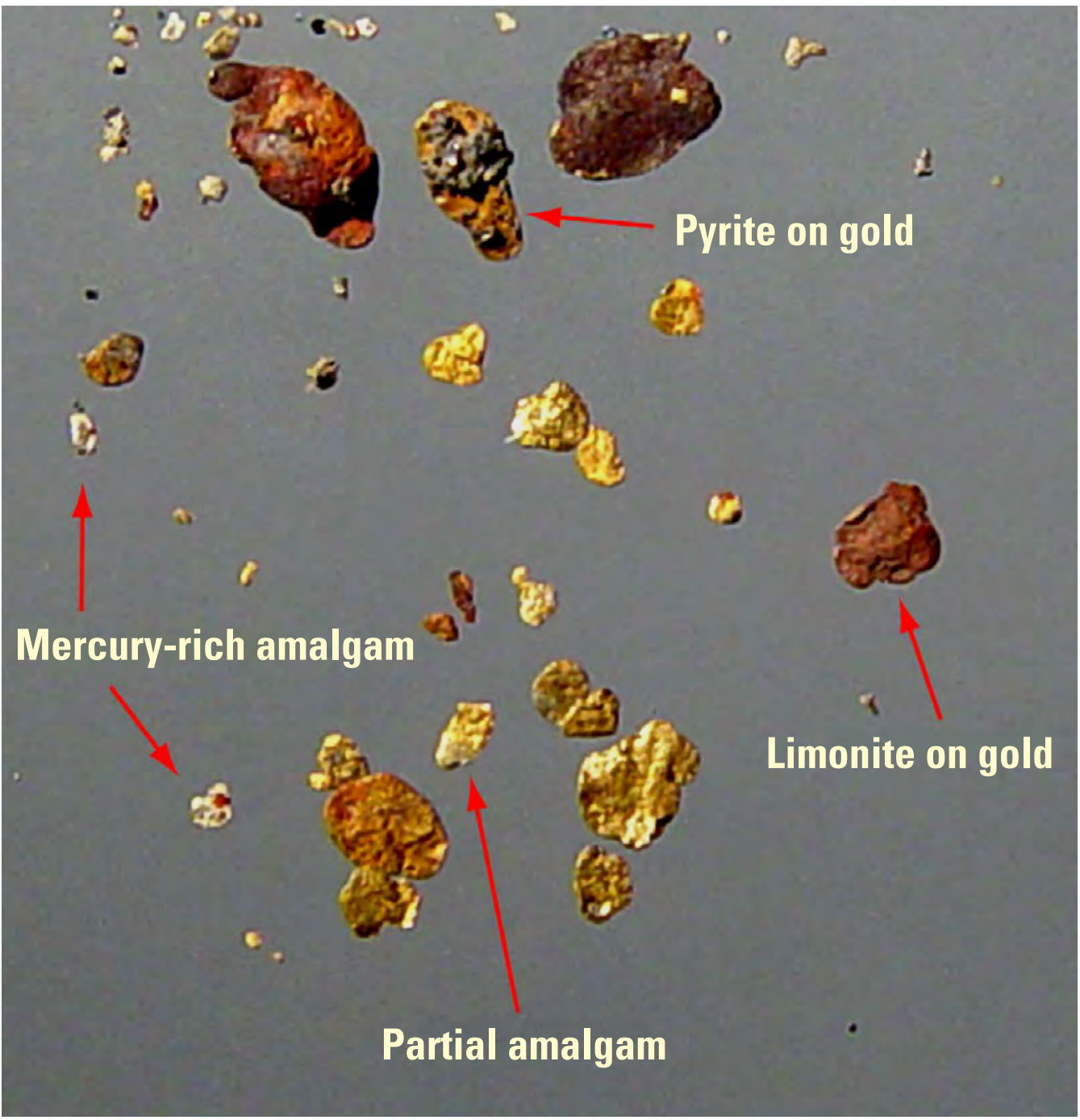

Figure 13. Gold and amalgam grains from heavy-mineral concentrate 5A from Englebright Lake, California. 


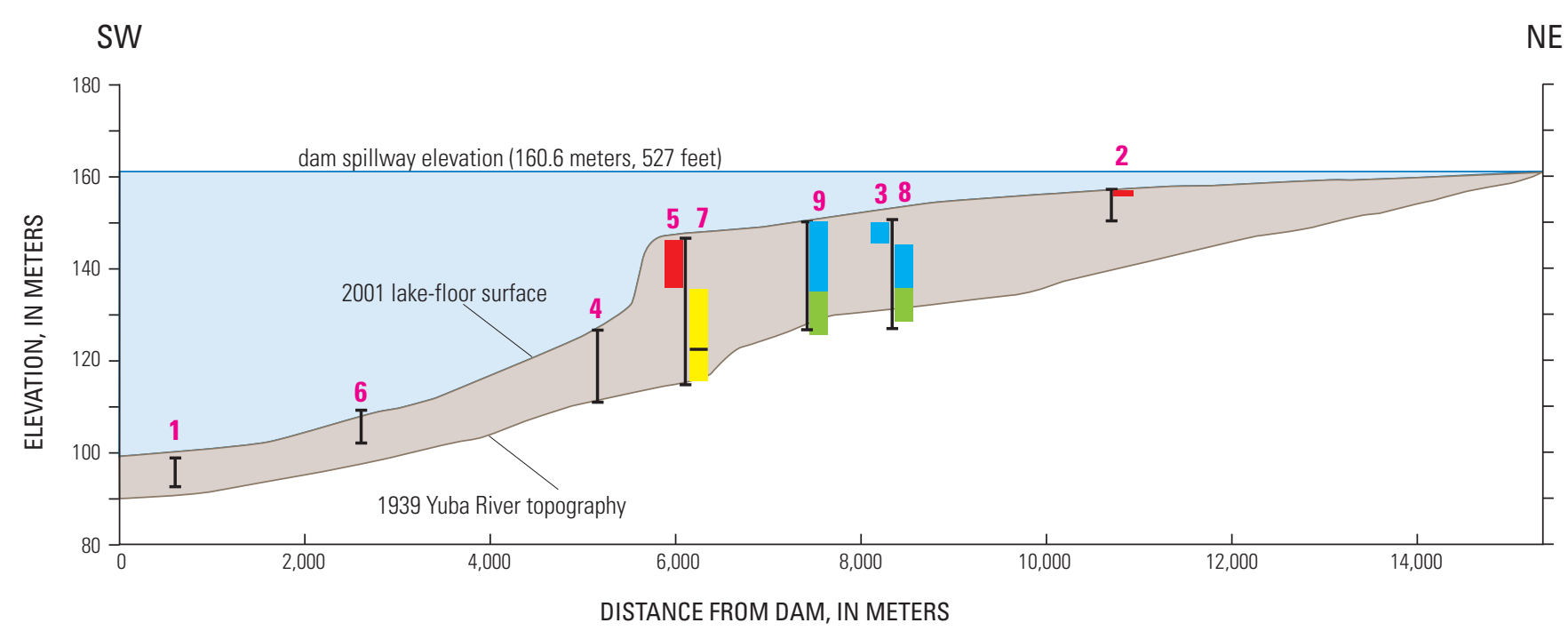

EXPLANATION

$\begin{array}{ll}\begin{array}{l}\text { Gold (Au), in milligrams } \\ \text { per cubic meter }\end{array} & \mathbf{2} \begin{array}{l}\text { Coring locations projected onto } \\ \text { pre-dam thalweg line }\end{array} \\ A u>600 & I_{- \text {Cored pre-dam elevation }}^{- \text {Measured lake-floor elevation }} \\ 600>A u>200 & \stackrel{6,000 \text { feet }}{\longrightarrow} \\ 200>A u>80 & \stackrel{\text { Scale conversion to feet }}{50 \text { feet vertical exaggeration }} \\ 80>A u & \end{array}$

Figure 14. Longitudinal section showing gold tenor in composite core intervals from Englebright Lake, California, 2002. Vertical exaggeration 50X. 2001 lake-floor surface from Childs and others (2003); 1939 Yuba River topography from U.S. Army Corps of Engineers maps, digitized by Childs and others (2003). Measured lake-floor elevation and cored pre-dam elevation from deep drilling, May-June 2002 (Childs and others, 2003; Snyder and others, 2004a).

\section{Summary and Conclusions}

Methods and results are presented for geochemical analyses of sediment samples from two coring campaigns at Englebright Lake, California, conducted by the U.S. Geological Survey: a deep coring campaign completed during MayJune 2002 and a shallow sampling campaign completed during October 2002. Total mercury was analyzed in 444 subsamples, methylmercury in 243 subsamples, and other trace and major elements in 202 subsamples. Quality-assurance and qualitycontrol procedures including analyses of replicate pairs of split subsamples (in some cases analyzed by two different laboratories), standard reference materials, blanks, and spike additions were used to demonstrate a high level of confidence in data quality for mercury, methylmercury, other trace elements, and major elements.

The spatial variation of total mercury $\left(\mathrm{Hg}_{\mathrm{T}}\right)$ and methylmercury $\left(\mathrm{MeHg}\right.$ ), and the ratio of $\mathrm{MeHg}$ to $\mathrm{Hg}_{\mathrm{T}}$ were evaluated using data derived from the deep and shallow cores. At the three deep coring sites closest to Englebright Dam, concentrations of $\mathrm{Hg}_{\mathrm{T}}$ were generally in the range of 100 to $500 \mathrm{ng} / \mathrm{g}$, dry (nanogram per gram), and the median grain size for most samples was in the silt range (0.004 to $0.063 \mathrm{~mm}$ [millimeter]). At the deep coring sites located farther upstream, the upper parts of the profile had coarser grain size; median values were in the sand range $(0.063$ to $2.0 \mathrm{~mm})$, and concentrations of $\mathrm{Hg}_{\mathrm{T}}$ in unsieved samples were lower, generally 2.0 to $100 \mathrm{ng} / \mathrm{g}$. The lower part of the vertical profiles at three upstream coring sites had finer median grain size and higher concentrations of $\mathrm{Hg}_{\mathrm{T}}$ in unsieved samples than the upper and middle parts of these profiles.

Longitudinal variation in $\mathrm{Hg}_{\mathrm{T}}$ concentration was more pronounced in deep cores than in shallow cores. Median values of $\mathrm{Hg}_{\mathrm{T}}$ in shallow cores from all ten sampling sites were consistently in the range of 204 to $265 \mathrm{ng} / \mathrm{g}$, and standard deviations generally were small, indicating that nearly all concentration values were in the range of 200 to $300 \mathrm{ng} / \mathrm{g}$. Median values of $\mathrm{Hg}_{\mathrm{T}}$ in unsieved deep cores showed considerable longitudinal variation; highest median values for $\mathrm{Hg}_{\mathrm{T}}$ were found at sites near the dam (344 and $355 \mathrm{ng} / \mathrm{g}$ ); lowest median values for $\mathrm{Hg}_{\mathrm{T}}$ were at the three most upstream sites (17 to $97 \mathrm{ng} / \mathrm{g}$ ), and intermediate values for $\mathrm{Hg}_{\mathrm{T}}$ were at the mid-reservoir sites (135 and $245 \mathrm{ng} / \mathrm{g}$ ). 
The ratio $\mathrm{MeHg} / \mathrm{Hg}_{\mathrm{T}}$ showed less variation among adjacent locations than the MeHg concentration when shallow and deep samples were compared. Lowest median values of $\mathrm{MeHg} / \mathrm{Hg}_{\mathrm{T}}$ were for the site closest to the dam both for shallow cores $(0.20$ percent $)$ and deep cores $(0.13$ percent $)$. The highest median values of $\mathrm{MeHg} / \mathrm{Hg}_{\mathrm{T}}$ were for shallow cores from the mid-reservoir and upstream sites $(0.31$ to 0.82 percent), and for deep cores from two mid-reservoir sites ( 0.33 and 0.34 percent) and the most upstream site ( 0.36 percent).

As expected based on observations in other freshwater systems, the shallowest samples $(0-4 \mathrm{~cm}$ [centimeter] below the reservoir floor) had a higher median concentration of $\mathrm{MeHg}(1.0 \mathrm{ng} / \mathrm{g})$ than deeper samples from the shallow cores (4-8 cm, $0.69 \mathrm{ng} / \mathrm{g} ; 8-12 \mathrm{~cm}, 0.59 \mathrm{ng} / \mathrm{g}$ ). The shallowest vertical interval had the highest value of the ratio $\mathrm{MeHg}$ to $\mathrm{Hg}_{\mathrm{T}}(0.38$ percent $)$ also. Median concentrations of $\mathrm{MeHg}$ and median values of $\mathrm{MeHg} / \mathrm{Hg}_{\mathrm{T}}$ decreased systematically with depth from $0-4$ to $4-8$ to $8-12 \mathrm{~cm}$ in the shallow cores. However, similar systematic decreases were not observed at the meter scale in the deep cores of the MEM series. The overall median of the ratio $\mathrm{MeHg} / \mathrm{Hg}_{\mathrm{T}}$ in the deep cores was 0.25 percent, not much lower than the overall median value for the shallow cores ( 0.33 percent).

The highest potential rates of microbial mercury methylation, determined with radiotracer methods, were measured in shallow ( 0 to 8 centimeter depth) sediments ( 5 to 30 nanograms of mercury per gram dry sediment per day), whereas potential rates for samples collected from depths greater than 500 centimeters were consistently near or below the detection limit of the radiotracer method. Shallow sediments also had higher average values of loss on ignition (a proxy for organic content) and porosity, significantly higher concentrations of most solid-phase Fe species, and lower dry weight (equivalent to a higher moisture content) than deeper sediments. These results are consistent with the direction of the observed trend toward lower concentrations of $\mathrm{MeHg}$ and lower values of $\mathrm{MeHg} / \mathrm{Hg}_{\mathrm{T}}$ in deep sediments compared with shallow sediments.

Chemical analyses of trace and major elements in bed sediment are presented for 202 samples of deep cores from five sites in Englebright Lake. The overall average values and standard deviations for selected trace elements were as follows (in micrograms per gram): antimony $2.4 \pm 1.6$, arsenic $69 \pm$ 48 , chromium $134 \pm 23$, lead $33 \pm 25$, and nickel $87 \pm 24$.

Heavy-mineral concentrates were prepared using nine large-volume composite samples from deep cores taken at four locations in the upper- and mid-reservoir. Estimated gold concentrations in sediment from ranged from 38 to 840 milligrams per cubic meter. Grains of gold-mercury amalgam and grains of electrum (native gold), with and without mercury staining, were observed in the heavy-mineral concentrates.

\section{References Cited}

Alpers, C.N., and Hunerlach, M.P., 2000, Mercury contamination from historic gold mining in California: U.S. Geological Survey Fact Sheet FS-061-00, 6 p. http://ca.water.usgs. gov/mercury/fs06100.html

Alpers, C.N., Taylor, H.E., and Domagalski, J.L., eds., 2000, Metals transport in the Sacramento River, California, 1996-1997: Volume 1. Methods and data: U.S. Geological Survey Water-Resources Investigations Report 99-4286, 430 p. http://water.usgs.gov/pubs/wri/wrir_994286

Alpers, C.N., Hunerlach, M.P., Marvin-DiPasquale, M.C., May, J.T., Hothem, R.L., Saiki, M.K., Stewart, A.R., Kuwabara, J.S., Taylor, H.E., and Krabbenhoft, D.P., 2004a, Mercury cycling and bioaccumulation in fish in northern Sierra Nevada watersheds contaminated by historical gold mining: American Fisheries Society, California, Nevada and Humboldt Chapters, Symposium and 38th Annual Meeting, Redding, Calif., April 22-24, 2004, Program, unnumbered pages.

Alpers, C.N., Hunerlach, M.P., Marvin-DiPasquale, M., Snyder, N.P., and Krabbenhoft, D.P., 2004b, Mercury and methylmercury in the upper Yuba River watershed: Fluvial transport and reservoir sedimentation: Third Biennial CALFED Bay-Delta Program Science Conference Abstracts, October 4-6, 2004, Sacramento, Calif., p. 4.

Alpers, C.N., Hunerlach, M.P., May, J.T., and Hothem, R.L., 2005a, Mercury contamination from historical gold mining in California: U.S. Geological Survey Fact Sheet 20053014, 6 p. http://water.usgs.gov/pubs/fs/2005/3014/

Alpers, C.N., Hunerlach, M.P., May, J.T., Hothem, R.L., Taylor, H.E., Antweiler, R.C., De Wild, J.F., and Lawler, D.A., 2005b, Geochemical characterization of water, sediment, and biota affected by mercury contamination and acidic drainage from historical gold mining, Greenhorn Creek, Nevada County, California, 1999-2001: U.S. Geological Survey Scientific Investigations Report 2004-5251, 278 p. http://water.usgs.gov/pubs/sir/2004/525l/

American Public Health Association, 1981, Section 209G: Volatile and fixed matter in nonfilterable residue and in solid and semisolid samples, in Franson, M.A.H., ed., Standard Methods for the Examination of Water and Wastewater (15th ed): Washington, D.C., American Water Works.

Ashley, R.P., 2002, Geoenvironmental model for low-sulfide gold-quartz vein deposits, in Seal, R.R. II and Foley, N.K. (eds.) Progress on Geoenvironmental Models for Selected Mineral Deposit Types: U.S. Geological Survey Open-File Report 02-195, p. 176-195.

Bloom, N.S., 1989, Determination of picogram levels of methylmercury by aqueous phase ethylation, followed by cryogenic gas chromatography with cold vapour atomic fluorescence detection: Canadian Journal of Fisheries and Aquatic Sciences, v. 46, no. 7, p. 1131-1140. 
Bloom, N.S., Colman, J.A., and Barber, L., 1997, Artifact formation of methylmercury during aqueous distillation and alternative techniques for the extraction of methyl mercury from environmental samples: Fresenius' Journal of Analytical Chemistry, v. 358, p. 371-377.

California Department of Conservation, 2006, TOMS: Topographically Occurring Mine Symbols. Office of Mine Reclamation, URL accessed July 6, 2006: http://www.consrv. ca.gov/OMR/abandoned_mine_lands/toms/

California Department of Water Resources, 2005, Fish passage improvement 2005: Bulletin 250, chap. 4, p. 4-9 to 4-10, also available at http://www.watershedrestoration.water. ca.gov/fishpassage/b250/content.html

Childs, J.R., Snyder, N.P., and Hampton, M.A., 2003, Bathymetric and geophysical surveys of Englebright Lake, Yuba-Nevada Counties, California: U.S. Geological Survey Open-File Report 03-383, 20 p. http://geopubs.wr.usgs. gov/open-file/of03-383/

Churchill, R.K., 2000, Contributions of mercury to California's environment from mercury and gold mining activities; Insights from the historical record, in Extended abstracts for the U.S. EPA sponsored meeting, Assessing and Managing Mercury from Historic and Current Mining Activities, November 28-30, 2000, San Francisco, Calif., p. 33-36 and S35-S48.

Clark, W.B., 1963, Gold districts of California: California Department of Conservation, Division of Mines and Geology: Bulletin 193, 199 p. plus one plate (some revisions through 1969; seventh printing, 1998).

Curtis, J.A., Flint, L.E., Alpers, C.N., and Yarnell, S., 2005, Conceptual model of sediment processes in the upper Yuba River watershed, Sierra Nevada, CA: Geomorphology, v. 68, p. 149-166. doi:10.1016/j.geomorph.2004.11.019

DeWild, J.F., Olund, S.D., Olson, M.L., and Tate, M.T., 2004, Methods for the preparation and analysis of solids and suspended solids for methylmercury: U.S. Geological Survey, Techniques and Methods in Water Resources, Chapter 7 of Book 5, Laboratory Analysis, Section A, Water Analysis, $13 \mathrm{p}$.

Dionex, 1992, Installation Instructions and Troubleshooting Guide for the IONPAC AG4A-SC Guard Column / IONPAC AS4A-SC Analytical Column: Dionex Corporation, Sunnyvale, Calif.

Fleming, E.J., Mack, E.E., Green, P.G., and Nelson, D.C., 2006, Mercury methylation from unexpected sources: Molybdate-inhibited freshwater sediments and an ironreducing bacterium: Applied and Environmental Microbiology, v. 72, p. 457-464.

Garbarino, J.R., and Taylor, H.E., 1979, Inductively coupled plasma-emission spectrometric method for routine water quality testing: Applied Spectroscopy, v. 33, p. 220-226.
Garbarino, J.R., and Taylor, H.E., 1996, Inductively coupled plasma-mass spectrometric method for the determination of dissolved trace elements in natural water: U.S. Geological Survey Open-File Report No. 94-358, 88 p.

Gilmour, C.C., Henry, E.A, and Mitchell, R., 1992, Sulfate stimulation of mercury methylation in freshwater sediments: Environmental Science \& Technology, v. 26, p. 2281-2287.

Hammerschmidt, C.R., and Fitzgerald, W.F., 2001, Formation of artifact methylmercury during extraction from a sediment reference material: Analytical Chemistry, v. 73, no. 24, p. 5930-5936.

Hayes, H.C., 1993, Metal associations in suspended sediments and bed sediments from the Mississippi River: Golden, Colo., Colorado School of Mines, M.S. thesis, 131 p.

Hintelmann, H., Falter, R., Ilgen, G., Evans, R.D., 1997, Determination of artifactual formation of monomethylmercury in environmental samples using stable $\mathrm{Hg}^{2+}$ isotopes with ICP-MS detection-calculation of contents applying species specific isotope addition: Fresenius' Journal of Analytical Chemistry, v. 358, p. 363-370.

Hintelmann, H., 1999, Comparison of different extraction techniques used for methylmercury analysis with respect to accidental formation of methylmercury during sample preparation: Chemosphere, v. 39, p. 1093-1105.

Horowitz, A.J., 1991, A primer on sediment-trace element chemistry (2d ed.): Boca Raton, Fla., Lewis Publishers, $136 \mathrm{p}$.

Horvat, M., Mandic, V., Liang, L., Bloom, N.S., Padberg, C.S., Lee, Y.-H. Hintelmann, H., and Benoit, J., 1994, Certification of methylmercury compounds: Concentration in marine sediment reference material, IAEA-356: Applied Organometallic Chemistry, v. 8, p. 533-540.

Hunerlach, M.P., Alpers, C.N., Marvin-DiPasquale, M., Taylor, H.E., and De Wild, J.F., 2004, Geochemistry of mercury and other trace elements in fluvial tailings upstream of Daguerre Point Dam, Yuba River, California, August 2001: U.S. Geological Survey Scientific Investigations Report 2004-5165, 66 p. http://pubs.usgs.gov/sir/2004/5165/

James, L.A., 2005, Sediment from hydraulic mining detained by Englebright and small dams in the Yuba Basin: Geomorphology, v. 71, p. 202-226. doi:10.1016/ j.geomorph.2004.02.016

Jørgensen, B.B., 1978, A comparison of methods for the quantification of bacterial sulfate reduction in coastal marine sediments. 1. Measurement with radiotracer techniques: Geomicrobiology Journal, v. 1, p. 11-27. 
Klasing, S., and Brodberg, R., 2003, Evaluation of potential health effects of eating fish from selected water bodies in the northern Sierra Nevada Foothills (Nevada, Placer, and Yuba Counties): Guidelines for sport fish consumption, December 2003, 46 p. http://www.oehha.ca.gov/fish/pdf/ SierraLakesAdvisoryfinal.pdf

Lasorsa, B., 2003a, Total mercury in tissues and sediments by cold vapor atomic absorption (CVAA): Battelle Marine Sciences Laboratory, Standard Operating Procedure MSL-I-016-06, 11 p.

Lasorsa, B., 2003b, Methylmercury in tissues and sediments by cold vapor atomic fluorescence (CVAF), Battelle Marine Sciences Laboratory, Standard Operating Procedure MSL-I-015-07, 16 p.

Long, K.R., DeYoung, J.H., Jr., and Ludington, S.D., 1998, Database of significant deposits of gold, silver, copper, lead, and zinc in the United States: U.S. Geological Survey OpenFile Report 98-206A, 33 p. Available at http://geopubs. wr.usgs.gov/open-file/of98-206/of98-206a.pdf

Lovley, D.R., and Phillips, E.J.P., 1987, Rapid assay for microbially reducible ferric iron in aquatic sediments: Applied Environmental Microbiology, v. 53, p. 1536-1540.

Marvin-DiPasquale, M., Agee, J., Bouse, R., and Jaffe, B., 2003, Microbial cycling of mercury in contaminated pelagic and wetland sediments of San Pablo Bay, California: Environmental Geology, v. 43, no. 3, p. 260-267.

May, J.T., Hothem, R.L., Alpers, C.N., and Law, M.A., 2000, Mercury bioaccumulation in fish in a region affected by historic gold mining: The South Yuba River, Deer Creek, and Bear River watersheds, California, 1999: U.S. Geological Survey Open-File Report 00-367, 30 p. http://ca.water.usgs. gov/archive/reports/ofr00367/

Mitko, K., and Bebek, M., 1999, ICP-OES determination of trace elements in salinated water: Atomic Spectroscopy, v. 20, p. 217-223.

Mitko, K., and Bebek, M., 2000, Determination of major elements in saline water samples using a dual-view ICP-OES: Atomic Spectroscopy, v. 21, p. 77-85.

National Institute of Standards and Technology, 1990, Certificate of analysis: Standard Reference Material 2704, Buffalo River Sediment, 5 p. (Revision of certificate dated June 1, 1988.)

National Institute of Standards and Technology, 2000, Report of Investigations: Standard Reference Material 8704, Buffalo River Sediment, 4 p. http://srmors.nist.gov/view_report. cfm?srm $=8704$
National Marine Fisheries Service, 2005, Endangered and threatened species: designation of critical habitat for seven evolutionarily significant units of pacific salmon and steelhead in California: National Marine Fisheries Service, National Oceanic and Atmospheric Administration, United States Department of Commerce. Final Rule. September 2, 2005, 70 FR 52488. p. 52,488-52,627.

Qian, J., and Mopper, K., 1996, Automated high-performance, high-temperature combustion total organic carbon analyzer: Analytical Chemistry, v. 68, no. 18, p. 3090-3097.

Roden, E.E. and Zachara, J.M., 1996. Microbial reduction of crystalline iron(III) oxides: Influence of oxide surface area and potential for cell growth: Environmental Science \& Technology, v. 30, no. 5, p. 1618-1628.

Roth, D.A., 1994, Ultratrace analysis of mercury and its distribution in some natural waters of the United States: Fort Collins, Colo., Colorado State University, Ph.D. dissertation, $309 \mathrm{p}$.

Slotton, D.G., Ayers, S.M., Alpers, C.N., and Goldman, C.R., 2004, Bioaccumulation legacy of Gold Rush mercury in watersheds of the Sierra Nevada of California. Third Biennial CALFED Bay-Delta Program Science Conference Abstracts, October 4-6, 2004, Sacramento, Calif., p. 388.

Slotton, D.G., Ayers, S.M., Reuter, J.E., and Goldman, C.R., 1997, Gold mining impacts on food chain mercury in northwestern Sierra Nevada streams. Appendix B, in Larry Walker Associates, Sacramento River Watershed mercury control planning project report for the Sacramento Regional County Sanitation District, $74 \mathrm{p}$.

Snyder, N.P., Alpers, C.N., Flint, L.E., Curtis, J.A., Hampton, M.A., Haskell, B.J., and Nielson, D.L., 2004a, Report on the May-June 2002 Englebright Lake deep coring campaign: U.S. Geological Survey Open-File Report 2004-1061, http://pubs.usgs.gov/of/2004/1061/

Snyder, N.P., Allen, J.R., Dare, C., Hampton, M.A., Schneider, G., Wooley, R.J., Alpers, C.N., and Marvin-DiPasquale, M.C., 2004b, Sediment grain-size and loss-on-ignition analyses from 2002 Englebright Lake coring and sampling campaigns: U.S. Geological Survey Open-File Report 2004-1080, http://pubs.usgs.gov/of/2004/1080/

Snyder, N.P., Rubin, D.M., Alpers, C.N., Childs, J.R., Curtis, J.A., Flint, L.E., and Wright, S.A., 2004c, Estimating rates and properties of sediment accumulation behind a dam: Englebright Lake, Yuba River, northern California: Water Resources Research, v. 40.W11301. doi:10.1029/ 2004WR003279

Snyder, N.P., Wright, S.A., Alpers, C.N., Flint, L.E., Holmes, C.W., and Rubin, D.M., in press, Reconstructing depositional processes and history from reservoir stratigraphy: Englebright Lake, Yuba River, northern California: Journal of Geophysical Research, Earth Surface, v. 111. doi:10.1029/200JF000451 
Stookey, L.L., 1970, Ferrozine - a new spectrophotometric reagent for iron: Analytical Chemistry, v. 42, p. 779-781.

Taylor, H.E., 2001, Inductively coupled plasma-mass spectrometry-practices and techniques: San Diego, Calif., Academic Press, 294 p.

Ulrich, G.A., Krumholz, L.R., and Suflita, J.M., 1997, A rapid and simple method for estimating sulfate reduction activity and quantifying inorganic sulfides: Applied and Environmental Microbiology, v. 63, no. 4, p. 1627-1630.

U.S. Environmental Protection Agency, 1991, Methods for the determination of metals in environmental samples, EPA600/4-91-010. Method 245.5 Determination of mercury in sediment by Cold Vapor Atomic Absorption Spectrometry, p. 267-280, http://www.epa.gov/microbes/methmans. html\#Metals\%20Orig

Van Metre, P.C., Callender, E., Mahler, B.J., Wilson, J.T., and Dorsey, M.E., 2001, Differences in lake and reservoir sedimentation - Implications for sediment coring studies: Proceedings of the Seventh Interagency Sedimentation Conference, v. 2, IX-12-19.

Van Metre, P.C., Wilson, J.T., Fuller, C.C., Callender, E., Mahler, B.J., 2004, Collection, analysis, and age dating of sediment cores from 56 U.S. lakes and reservoirs sampled by the U.S. Geological Survey, 1992-2001: U.S. Geological Survey Scientific Investigations Report 2004-5184, 180 p.
Wiener, J.G., Krabbenhoft, D.P., Heinz, G.H., and Scheuhammer, A.M., 2003, Ecotoxicology of mercury, chap. 16 in Hoffman, D.J., Rattner, B.A., Burton, G.A., Jr., and Cairns J., Jr., eds., Handbook of Ecotoxicology, (2d ed.): Boca Raton, Florida, CRC Press, p. 409-463.

Wyse, E.J., Coquery, M., Azemard, S., and de Mora, S. J., 2004, Characterization of trace elements and methylmercury in an estuarine sediment reference material, IAEA405: Journal of Environmental Monitoring, v. 6, p. 48-57. doi: 10.1039/b308584h (First published as an Advance Article on the Web Dec. 8, 2003.)

Yeend, W.E., 1974, Gold-bearing gravels of the ancestral Yuba River, Sierra Nevada, California: U.S. Geological Survey Professional Paper 772, 44 p. 


\section{Appendixes}




\section{Appendix A. Quality Assurance and Quality Control Data for Mercury and Methylmercury Analyses}

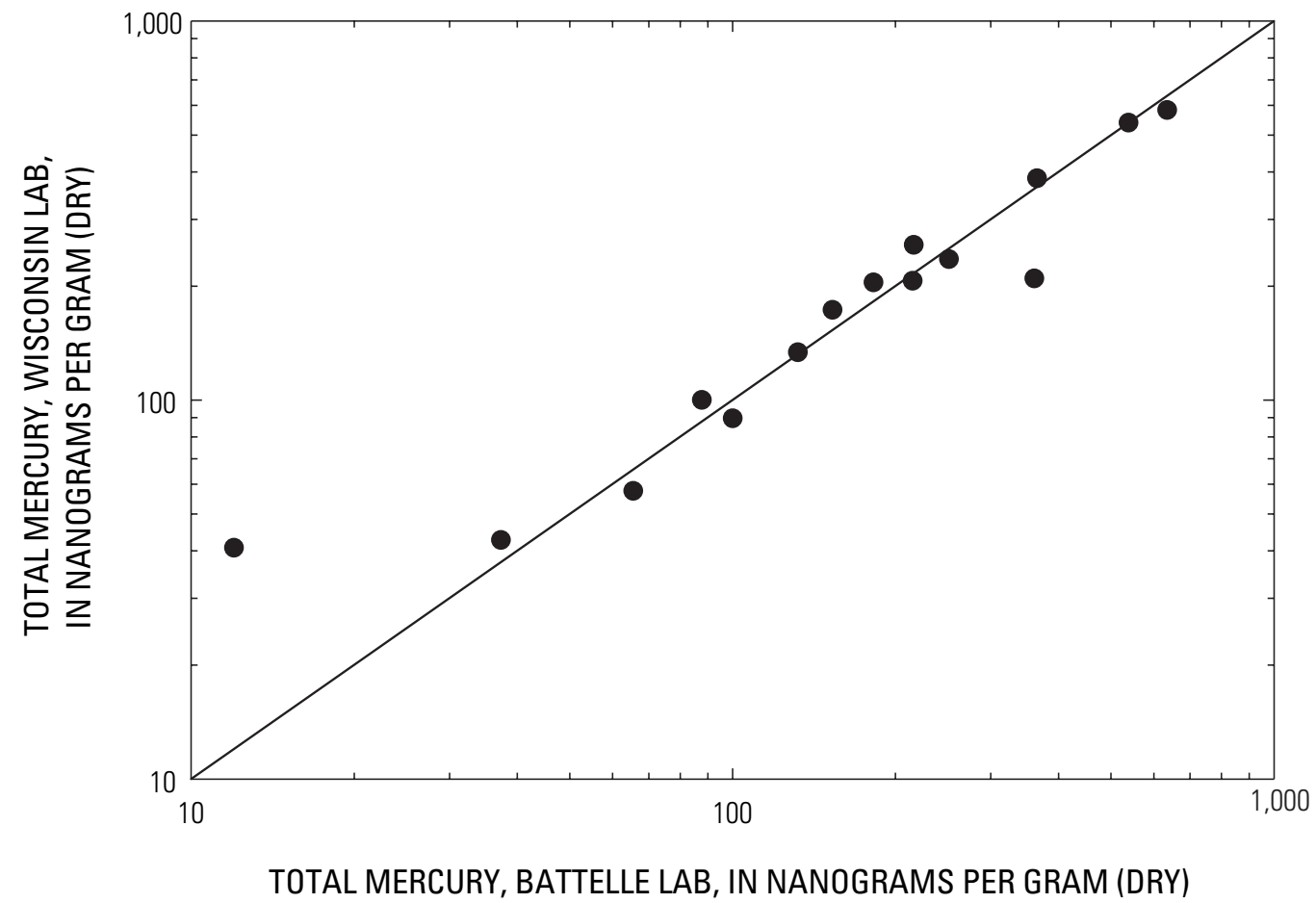

Figure A1. Results of analysis by two laboratories of total mercury in split subsamples from Englebright Lake, California, 2002.

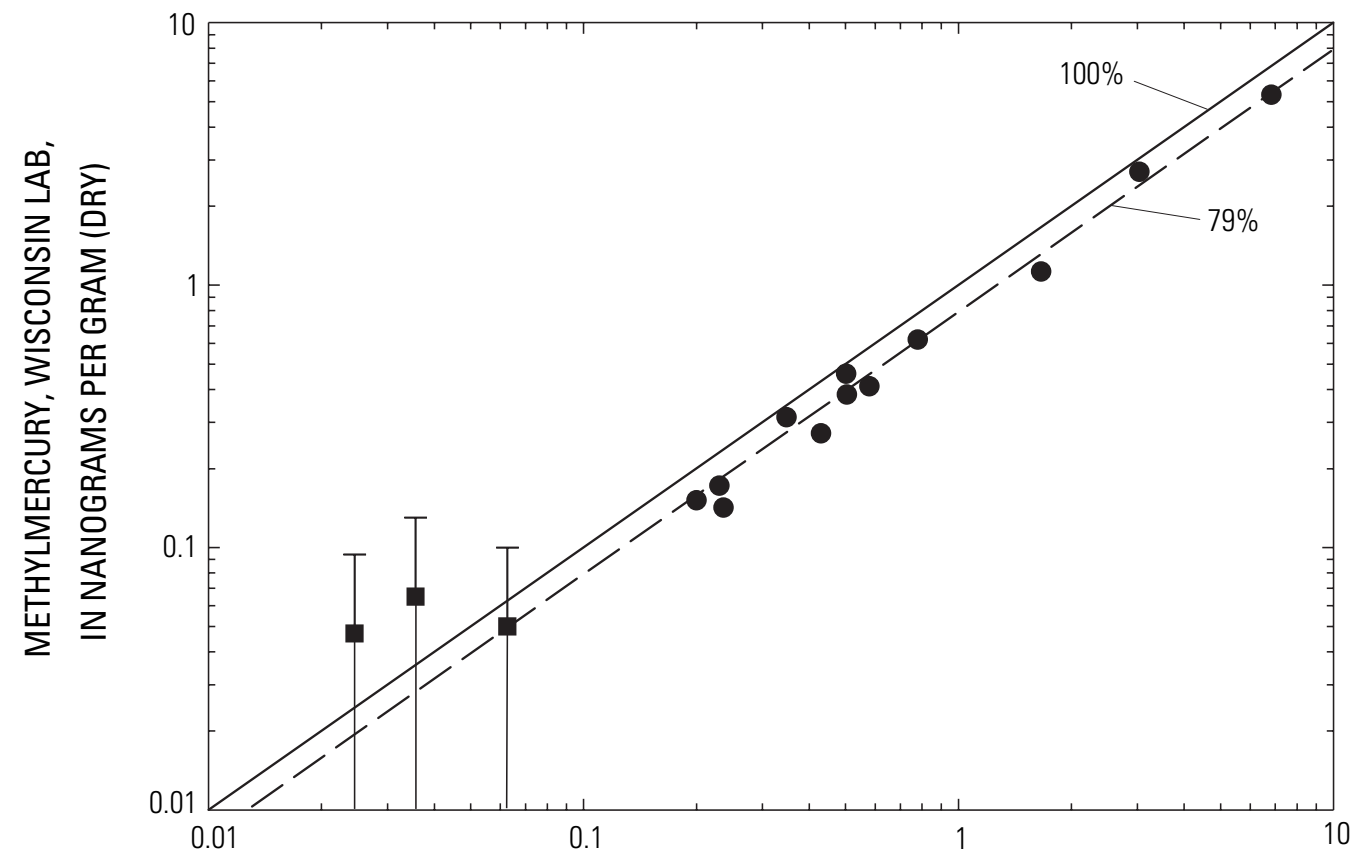

METHYLMERCURY, BATTELLE LAB, IN NANOGRAMS PER GRAM (DRY)

Figure A2. Results of analysis by two laboratories of methylmercury in split subsamples from Englebright Lake, California, 2002. Results less than detection limit are indicated by a symbol at half the detection limit and an error bar from the axis to the detection limit. 
Table A1. Total mercury concentrations in standard reference materials.

[Recovery is equal to observed value divided by certified value. \%, percent; $n$, number of analyses. ng/g, nanogram per gram; -, not determined]

\begin{tabular}{|c|c|c|c|c|c|}
\hline & \multicolumn{3}{|c|}{ Total mercury } & \multirow[b]{2}{*}{$\begin{array}{c}\text { Recovery } \\
(\%)\end{array}$} & \multirow[b]{2}{*}{$\begin{array}{c}\text { Laboratory } \\
\text { batch }\end{array}$} \\
\hline & $\begin{array}{c}\text { Certified } \\
\text { value } \\
\text { ng/g } \\
\text { (dry) }\end{array}$ & $\begin{array}{l}\text { Observed } \\
\text { value } \\
\text { ng/g } \\
\text { dry) }\end{array}$ & $\begin{array}{c}\text { Standard } \\
\text { deviation } \\
\mathrm{ng} / \mathrm{g} \\
\text { (dry) }\end{array}$ & & \\
\hline \multicolumn{6}{|c|}{ Laboratory: U.S. Geological Survey, Boulder, Colo. } \\
\hline Buffalo River Sediment 2704 & 1,470 & 1,357 & 15 & 92 & $1 \mathrm{Y}$ \\
\hline Buffalo River Sediment 2704 & 1,470 & 1,342 & 5 & 91 & $1 \mathrm{Y}$ \\
\hline Buffalo River Sediment 2704 & 1,470 & 1,478 & 5 & 101 & $1 \mathrm{Y}$ \\
\hline Buffalo River Sediment 2704 & 1,470 & 1,464 & 16 & 100 & $7 \mathrm{Y}$ \\
\hline Buffalo River Sediment 2704 & 1,470 & 1,433 & 11 & 98 & $7 Y$ \\
\hline Buffalo River Sediment 2704 & 1,470 & 1,427 & 10 & 97 & $7 \mathrm{Y}$ \\
\hline Buffalo River Sediment 2704 & 1,470 & 1,463 & 11 & 100 & $7 Y$ \\
\hline Buffalo River Sediment 2704 & 1,470 & 1,427 & 9 & 97 & $7 \mathrm{Y}$ \\
\hline Buffalo River Sediment 2704 & 1,470 & 1,621 & 40 & 110 & $7 \mathrm{Y}$ \\
\hline Buffalo River Sediment 2704 & 1,470 & 1,425 & 20 & 97 & $7 Y$ \\
\hline Buffalo River Sediment 2704 & 1,470 & 1,795 & 6 & 122 & $7 \mathrm{Y}$ \\
\hline Buffalo River Sediment 2704 & 1,470 & 1,588 & 18 & 108 & $7 Y$ \\
\hline Buffalo River Sediment 2704 & 1,470 & 1,635 & 8 & 111 & $7 Y$ \\
\hline Buffalo River Sediment 2704 & 1,470 & 1,735 & 20 & 118 & $7 \mathrm{Y}$ \\
\hline Buffalo River Sediment 2704 & 1,470 & 1,485 & 16 & 101 & $9 Y$ \\
\hline Buffalo River Sediment 2704 & 1,470 & 1,564 & 7 & 106 & $9 \mathrm{Y}$ \\
\hline Buffalo River Sediment 2704 & 1,470 & 1,458 & 21 & 99 & $9 Y$ \\
\hline Buffalo River Sediment 2704 & 1,470 & 1,603 & 10 & 109 & $9 Y$ \\
\hline Buffalo River Sediment 2704 & 1,470 & 1,227 & 10 & 83 & $9 Y$ \\
\hline Buffalo River Sediment 2704 & 1,470 & 1,483 & 1 & 101 & $9 \mathrm{Y}$ \\
\hline Buffalo River Sediment 2704 & 1,470 & 1,458 & 16 & 99 & $9 Y$ \\
\hline Buffalo River Sediment 2704 & 1,470 & 1,447 & 4 & 98 & $8 Y$ \\
\hline Buffalo River Sediment 2704 & 1,470 & 1,329 & 26 & 90 & $8 Y$ \\
\hline Buffalo River Sediment 2704 & 1,470 & 1,604 & 23 & 109 & $8 Y$ \\
\hline Buffalo River Sediment 2704 & 1,470 & 1,513 & 29 & 103 & $8 Y$ \\
\hline Buffalo River Sediment 2704 & 1,470 & 1,347 & 28 & 92 & $8 Y$ \\
\hline Buffalo River Sediment 2704 & 1,470 & 1,403 & 42 & 95 & $8 Y$ \\
\hline mean & 1,470 & 1,486 & & 101 & \\
\hline uncertainty (95\% prediction interval) & 70 & - & & & \\
\hline standard deviation & - & 126 & & 9 & \\
\hline $\mathrm{n}$ & & 27 & & 27 & \\
\hline
\end{tabular}


Table A1. Total mercury concentrations in standard reference materials-Continued.

[Recovery is equal to observed value divided by certified value. \%, percent; $n$, number of analyses. ng/g, nanogram per gram; -, not determined]

\begin{tabular}{|c|c|c|c|c|c|}
\hline & \multicolumn{3}{|c|}{ Total mercury } & \multirow[b]{2}{*}{$\begin{array}{c}\text { Recovery } \\
\text { (\%) }\end{array}$} & \multirow[b]{2}{*}{$\begin{array}{l}\text { Laboratory } \\
\text { batch }\end{array}$} \\
\hline & $\begin{array}{c}\text { Certified } \\
\text { value } \\
\text { ng/g } \\
\text { (dry) }\end{array}$ & $\begin{array}{l}\text { Observed } \\
\text { value } \\
\text { ng/g } \\
\text { dry) }\end{array}$ & $\begin{array}{c}\text { Standard } \\
\text { deviation } \\
\text { ng/g } \\
\text { (dry) }\end{array}$ & & \\
\hline \multicolumn{6}{|c|}{ Laboratory: Battelle Marine Sciences Laboratory, Sequim, Wash. } \\
\hline IAEA 405 & 810 & 803 & - & 99 & 072503HGB \\
\hline IAEA 405 & 810 & 813 & - & 100 & 072503HGB \\
\hline IAEA 405 & 810 & 828 & - & 102 & 072903HGB \\
\hline IAEA 405 & 810 & 820 & - & 101 & 072903HGB \\
\hline IAEA 405 & 810 & 824 & - & 102 & 080803HGB \\
\hline IAEA 405 & 810 & 833 & - & 103 & 080803HGB \\
\hline IAEA 405 & 810 & 839 & - & 104 & 082003HGB \\
\hline IAEA 405 & 810 & 825 & - & 102 & 092203HGB \\
\hline IAEA 405 & 810 & 800 & - & 99 & 092203HGB \\
\hline IAEA 405 & 810 & 793 & - & 98 & 092203HGB \\
\hline IAEA 405 & 810 & 912 & - & 113 & 092203HGB \\
\hline IAEA 405 & 810 & 870 & - & 107 & 100103HGB \\
\hline IAEA 405 & 810 & 844 & - & 104 & 100103HGB \\
\hline IAEA 405 & 810 & 844 & - & 104 & 100103HGB \\
\hline mean & 810 & 832 & & 103 & \\
\hline standard deviation & 40 & 31 & & 4 & \\
\hline $\mathrm{n}$ & & 14 & & 14 & \\
\hline
\end{tabular}


Table A2. Total mercury data for replicate sediment subsamples from Englebright Lake, California, 2002.

[R1, replicate 1; R2, replicate 2; R3, replicate 3; RPD, relative percentage difference; $\mathrm{n}$, number of analyses; cm, centimeter; ng/g, nanogram per gram]

\begin{tabular}{|c|c|c|c|c|c|c|c|c|c|}
\hline \multirow[b]{2}{*}{ Site ID } & \multirow{2}{*}{$\begin{array}{l}\text { Depth } \\
\text { within } \\
\text { core } \\
\text { sample } \\
\text { (cm) }\end{array}$} & \multirow[b]{2}{*}{ Lab ID } & \multirow{2}{*}{$\begin{array}{l}\text { Type of } \\
\text { replicate } \\
\text { (C=core, } \\
\text { L=Lab) }\end{array}$} & \multicolumn{3}{|c|}{ Total mercury concentration } & \multicolumn{3}{|c|}{ RPD } \\
\hline & & & & $\underset{\text { (ng/g, dry) }}{\text { R1 }}$ & $\begin{array}{c}\text { R2 } \\
\text { (ng/g, dry) }\end{array}$ & $\begin{array}{c}\text { R3 } \\
\text { (ng/g, dry) }\end{array}$ & R1, R2 & R1, R3 & $\mathrm{R} 2, \mathrm{R} 3$ \\
\hline \multicolumn{10}{|c|}{ Laboratory: U.S. Geological Survey, Boulder, Colo. } \\
\hline \multicolumn{10}{|c|}{ Y-series: Deep cores } \\
\hline $1 \mathrm{~B}-2 \mathrm{E}-2$ & $0-75$ & $1 \mathrm{Y}-8$ & $\mathrm{~L}$ & 202 & 196 & & 3.4 & & \\
\hline 1B-2E-3 & 80-108 & $1 \mathrm{Y}-11$ & $\mathrm{~L}$ & 366 & 343 & & 6.5 & & \\
\hline 1B-3E-1 & $0-52$ & $1 \mathrm{Y}-16$ & $\mathrm{~L}$ & 258 & 265 & & 2.8 & & \\
\hline 1B-3E-1 & 90-101 & $1 \mathrm{Y}-19$ & $\mathrm{~L}$ & 253 & 240 & 251 & 5.1 & 0.8 & 4.5 \\
\hline 7A-4H-2 & $29.5-73$ & $7 Y-21$ & $\mathrm{~L}$ & 589 & 585 & & 0.7 & & \\
\hline 7C-7H-2 & $68-120$ & $7 Y-34$ & $\mathrm{~L}$ & 477 & 523 & & 9.2 & & \\
\hline $7 \mathrm{C}-9 \mathrm{H}-3$ & $0-93.5$ & $7 \mathrm{Y}-41$ & $\mathrm{~L}$ & 480 & 488 & & 1.7 & & \\
\hline 7C-11H-1 & $21-70$ & $7 Y-48$ & $\mathrm{~L}$ & 462 & 446 & & 3.6 & & \\
\hline $7 \mathrm{C}-12 \mathrm{H}-2$ & $0-40.5$ & $7 Y-57$ & $\mathrm{~L}$ & 332 & 336 & & 1.2 & & \\
\hline $7 \mathrm{C}-12 \mathrm{H}-2$ & 69-104 & $7 Y-59$ & $\mathrm{~L}$ & 259 & 262 & & 0.9 & & \\
\hline $7 \mathrm{C}-13 \mathrm{H}-3$ & $61.5-99$ & $7 Y-66$ & $\mathrm{~L}$ & 188 & 194 & & 3.3 & & \\
\hline $9 \mathrm{~A}-1 \mathrm{H}-2$ & $25.5-119$ & $9 \mathrm{Y}-2$ & $\mathrm{~L}$ & 292 & 284 & & 3.0 & & \\
\hline $9 \mathrm{~A}-10 \mathrm{H}-3$ & $94.5-135.5$ & $9 Y-35$ & $\mathrm{~L}$ & 192 & 184 & & 3.9 & & \\
\hline $9 \mathrm{C}-9 \mathrm{H}-3$ & $41-99$ & $9 Y-37$ & $\mathrm{C}$ & 151 & 153 & & 1.7 & & \\
\hline $8 \mathrm{~A}-1 \mathrm{H}-3$ & $127.5-150$ & $8 Y-6$ & $\mathrm{~L}$ & 247 & 263 & & 6.2 & & \\
\hline $8 \mathrm{~B}-3 \mathrm{H}-2$ & $0-136$ & $8 Y-17$ & $\mathrm{C}$ & 232 & 221 & & 4.7 & & \\
\hline
\end{tabular}


Table A2. Total mercury data for replicate sediment subsamples from Englebright Lake, California, 2002-Continued.

[R1, replicate 1; R2, replicate 2; R3, replicate 3; RPD, relative percentage difference; n, number of analyses; cm, centimeter; ng/g, nanogram per gram]

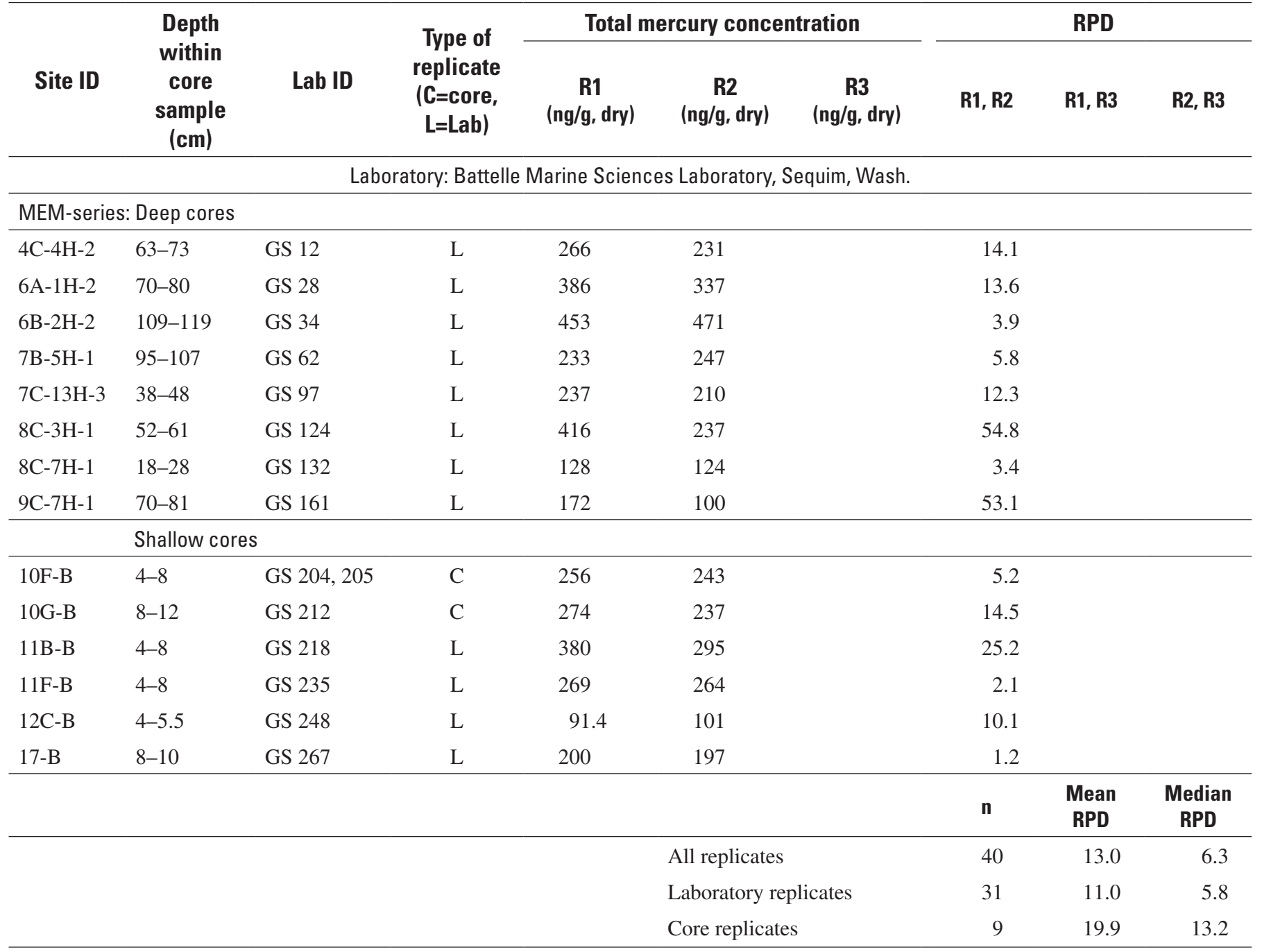


Table A3. Methylmercury concentrations in standard reference materials.

[Recovery is equal to observed value divided by certified value. n, number of analyses; \%, percentage; ng/g, nanogram per gram; na, not applicable]

\begin{tabular}{|c|c|c|c|c|}
\hline \multirow[b]{2}{*}{$\begin{array}{c}\text { Standard } \\
\text { reference } \\
\text { material }\end{array}$} & \multicolumn{2}{|c|}{ Methylmercury } & \multirow[b]{2}{*}{$\begin{array}{c}\text { Recovery } \\
(\%)\end{array}$} & \multirow[b]{2}{*}{ Date of analysis } \\
\hline & $\begin{array}{l}\text { Certified } \\
\text { value } \\
\text { ng/g (dry) }\end{array}$ & $\begin{array}{l}\text { Observed } \\
\text { value } \\
\text { ng/g (dry) }\end{array}$ & & \\
\hline \multicolumn{5}{|c|}{ Laboratory: Battelle Marine Sciences Laboratory, Sequim, Wash. } \\
\hline IAEA-356 & 5.46 & 4.79 & 88 & $7 / 14 / 2003$ \\
\hline IAEA-356 & 5.46 & 4.60 & 84 & $7 / 15 / 2003$ \\
\hline IAEA-356 & 5.46 & 4.26 & 78 & $7 / 16 / 2003$ \\
\hline IAEA-356 & 5.46 & 4.51 & 83 & $7 / 18 / 2003$ \\
\hline IAEA-356 & 5.46 & 4.61 & 84 & $7 / 22 / 2003$ \\
\hline IAEA-356 & 5.46 & 3.75 & 69 & $7 / 23 / 2003$ \\
\hline IAEA-356 & 5.46 & 4.78 & 88 & $7 / 31 / 2003$ \\
\hline IAEA-356 & 5.46 & 4.96 & 91 & $8 / 6 / 2003$ \\
\hline IAEA-356 & 5.46 & 4.74 & 87 & $8 / 8 / 2003$ \\
\hline IAEA-356 & 5.46 & 3.36 & 62 & $9 / 3 / 2003$ \\
\hline IAEA-356 & 5.46 & 4.12 & 75 & $9 / 4 / 2003$ \\
\hline IAEA-356 & 5.46 & 4.06 & 74 & $9 / 5 / 2003$ \\
\hline IAEA-356 & 5.46 & 2.29 & 42 & $9 / 12 / 2003$ \\
\hline IAEA-356 & 5.46 & 3.58 & 66 & $9 / 16 / 2003$ \\
\hline IAEA-356 & 5.46 & 2.96 & 54 & 9/18/2003 \\
\hline IAEA-356 & 5.46 & 3.55 & 65 & $9 / 23 / 2003$ \\
\hline IAEA-356 & 5.46 & 4.02 & 74 & $9 / 24 / 2003$ \\
\hline IAEA-356 & 5.46 & 3.93 & 72 & $9 / 25 / 2003$ \\
\hline IAEA-356 & 5.46 & 3.92 & 72 & $9 / 26 / 2003$ \\
\hline mean & 5.46 & 4.06 & 74 & \\
\hline standard deviation & 0.39 & 0.69 & 13 & \\
\hline $\mathrm{n}$ & na & 19 & 19 & \\
\hline \multicolumn{5}{|c|}{ Laboratory: Battelle Marine Sciences Laboratory, Sequim, Wash. } \\
\hline IAEA-405 & 5.49 & 4.95 & 90 & $7 / 14 / 2003$ \\
\hline IAEA-405 & 5.49 & 4.56 & 83 & $7 / 15 / 2003$ \\
\hline IAEA-405 & 5.49 & 5.19 & 95 & $7 / 16 / 2003$ \\
\hline IAEA-405 & 5.49 & 4.13 & 75 & $7 / 18 / 2003$ \\
\hline IAEA-405 & 5.49 & 5.22 & 95 & $7 / 22 / 2003$ \\
\hline IAEA-405 & 5.49 & 5.07 & 92 & $7 / 23 / 2003$ \\
\hline IAEA-405 & 5.49 & 4.42 & 81 & $7 / 31 / 2003$ \\
\hline IAEA-405 & 5.49 & 4.55 & 83 & $8 / 6 / 2003$ \\
\hline IAEA-405 & 5.49 & 4.54 & 83 & 8/8/2003 \\
\hline IAEA-405 & 5.49 & 3.93 & 72 & $9 / 3 / 2003$ \\
\hline IAEA-405 & 5.49 & 4.31 & 79 & $9 / 4 / 2003$ \\
\hline IAEA-405 & 5.49 & 4.41 & 80 & $9 / 12 / 2003$ \\
\hline IAEA-405 & 5.49 & 4.48 & 82 & $9 / 16 / 2003$ \\
\hline IAEA-405 & 5.49 & 3.45 & 63 & $9 / 18 / 2003$ \\
\hline
\end{tabular}


Table A3. Methylmercury concentrations in standard reference materials-Continued.

[Recovery is equal to observed value divided by certified value. n, number of analyses;

$\%$, percentage; ng/g, nanogram per gram; na, not applicable]

\begin{tabular}{|c|c|c|c|c|}
\hline \multirow[b]{2}{*}{$\begin{array}{c}\text { Standard } \\
\text { reference } \\
\text { material }\end{array}$} & \multicolumn{2}{|c|}{ Methylmercury } & \multirow[b]{2}{*}{$\begin{array}{c}\text { Recovery } \\
(\%)\end{array}$} & \multirow[b]{2}{*}{ Date of analysis } \\
\hline & $\begin{array}{l}\text { Certified } \\
\text { value } \\
\text { ng/g (dry) }\end{array}$ & $\begin{array}{l}\text { Observed } \\
\text { value } \\
\mathrm{ng} / \mathrm{g} \text { (dry) }\end{array}$ & & \\
\hline \multicolumn{5}{|c|}{ Laboratory: Battelle Marine Sciences Laboratory, Sequim, Wash. -Continued } \\
\hline IAEA-405 & 5.49 & 5.15 & 94 & $9 / 23 / 2003$ \\
\hline IAEA-405 & 5.49 & 4.97 & 91 & $9 / 24 / 2003$ \\
\hline IAEA-405 & 5.49 & 4.66 & 85 & $9 / 25 / 2003$ \\
\hline IAEA-405 & 5.49 & 4.66 & 85 & $9 / 26 / 2003$ \\
\hline mean & 5.49 & 4.59 & 84 & \\
\hline standard deviation & 0.53 & 0.47 & 8 & \\
\hline $\mathrm{n}$ & na & 18 & 18 & \\
\hline \multicolumn{5}{|c|}{ Laboratory: U.S. Geological Survey Laboratory, Middleton, Wisc. } \\
\hline IAEA-356 & 5.46 & 5.08 & 93 & $2 / 8 / 2005$ \\
\hline IAEA-356 & 5.46 & 4.23 & 77 & $2 / 10 / 2005$ \\
\hline IAEA-356 & 5.46 & 5.10 & 93 & $2 / 10 / 2005$ \\
\hline IAEA-356 & 5.46 & 6.37 & 117 & $2 / 10 / 2005$ \\
\hline IAEA-356 & 5.46 & 6.64 & 122 & $3 / 1 / 2005$ \\
\hline IAEA-356 & 5.46 & 5.11 & 94 & $3 / 2 / 2005$ \\
\hline IAEA-356 & 5.46 & 5.60 & 103 & $3 / 4 / 2005$ \\
\hline IAEA-356 & 5.46 & 4.90 & 90 & $3 / 9 / 2005$ \\
\hline IAEA-356 & 5.46 & 5.57 & 102 & $3 / 15 / 2005$ \\
\hline IAEA-356 & 5.46 & 4.47 & 82 & $3 / 16 / 2005$ \\
\hline IAEA-356 & 5.46 & 5.59 & 102 & $3 / 16 / 2005$ \\
\hline IAEA-356 & 5.46 & 4.03 & 74 & $3 / 23 / 2005$ \\
\hline IAEA-356 & 5.46 & 5.05 & 92 & $3 / 23 / 2005$ \\
\hline IAEA-356 & 5.46 & 4.02 & 74 & $3 / 24 / 2005$ \\
\hline IAEA-356 & 5.46 & 4.66 & 85 & $3 / 24 / 2005$ \\
\hline IAEA-356 & 5.46 & 4.44 & 81 & $3 / 30 / 2005$ \\
\hline IAEA-356 & 5.46 & 4.42 & 81 & $3 / 31 / 2005$ \\
\hline IAEA-356 & 5.46 & 4.79 & 88 & $3 / 31 / 2005$ \\
\hline mean & 5.46 & 5.00 & 92 & \\
\hline standard deviation & 0.39 & 0.74 & 14 & \\
\hline $\mathrm{n}$ & na & 18 & 18 & \\
\hline
\end{tabular}


Table A3. Methylmercury concentrations in standard reference materials-Continued.

[Recovery is equal to observed value divided by certified value. $n$, number of analyses;

$\%$, percentage; ng/g, nanogram per gram; na, not applicable]

\begin{tabular}{|c|c|c|c|c|}
\hline \multirow[b]{2}{*}{$\begin{array}{c}\text { Standard } \\
\text { reference } \\
\text { material }\end{array}$} & \multicolumn{2}{|c|}{ Methylmercury } & \multirow[b]{2}{*}{$\begin{array}{c}\text { Recovery } \\
(\%)\end{array}$} & \multirow[b]{2}{*}{ Date of analysis } \\
\hline & $\begin{array}{l}\text { Certified } \\
\text { value } \\
\text { ng/g (dry) }\end{array}$ & $\begin{array}{l}\text { Observed } \\
\text { value } \\
\text { ng/g (dry) }\end{array}$ & & \\
\hline \multicolumn{5}{|c|}{ Laboratory: U.S. Geological Survey Laboratory, Middleton, Wisc.-Continued } \\
\hline IAEA-405 & 5.49 & 3.32 & 61 & $6 / 10 / 2004$ \\
\hline IAEA-405 & 5.49 & 3.33 & 61 & $12 / 2 / 2004$ \\
\hline IAEA-405 & 5.49 & 4.91 & 89 & $12 / 2 / 2004$ \\
\hline IAEA-405 & 5.49 & 3.04 & 55 & $3 / 1 / 2005$ \\
\hline IAEA-405 & 5.49 & 3.86 & 70 & $3 / 2 / 2005$ \\
\hline IAEA-405 & 5.49 & 3.46 & 63 & $3 / 4 / 2005$ \\
\hline IAEA-405 & 5.49 & 5.12 & 93 & $3 / 9 / 2005$ \\
\hline IAEA-405 & 5.49 & 4.55 & 83 & $4 / 19 / 2005$ \\
\hline IAEA-405 & 5.49 & 5.47 & 100 & $4 / 19 / 2005$ \\
\hline IAEA-405 & 5.49 & 4.41 & 80 & $4 / 21 / 2005$ \\
\hline IAEA-405 & 5.49 & 5.82 & 106 & $4 / 21 / 2005$ \\
\hline IAEA-405 & 5.49 & 2.91 & 53 & $4 / 30 / 2005$ \\
\hline IAEA-405 & 5.49 & 3.93 & 72 & $4 / 30 / 2005$ \\
\hline IAEA-405 & 5.49 & 3.24 & 59 & $5 / 4 / 2005$ \\
\hline IAEA-405 & 5.49 & 4.18 & 76 & $5 / 4 / 2005$ \\
\hline IAEA-405 & 5.49 & 4.62 & 84 & $5 / 5 / 2005$ \\
\hline IAEA-405 & 5.49 & 2.78 & 51 & $6 / 28 / 2005$ \\
\hline IAEA-405 & 5.49 & 3.96 & 72 & $6 / 28 / 2005$ \\
\hline IAEA-405 & 5.49 & 3.68 & 67 & $6 / 29 / 2005$ \\
\hline IAEA-405 & 5.49 & 3.92 & 71 & $6 / 29 / 2005$ \\
\hline IAEA-405 & 5.49 & 3.33 & 61 & $6 / 30 / 2005$ \\
\hline IAEA-405 & 5.49 & 5.01 & 91 & $6 / 30 / 2005$ \\
\hline IAEA-405 & 5.49 & 2.91 & 53 & $7 / 7 / 2005$ \\
\hline IAEA-405 & 5.49 & 3.06 & 56 & $7 / 7 / 2005$ \\
\hline mean & 5.49 & 3.95 & 72 & \\
\hline standard deviation & 0.53 & 0.87 & 16 & \\
\hline $\mathrm{n}$ & na & 24 & 24 & \\
\hline
\end{tabular}




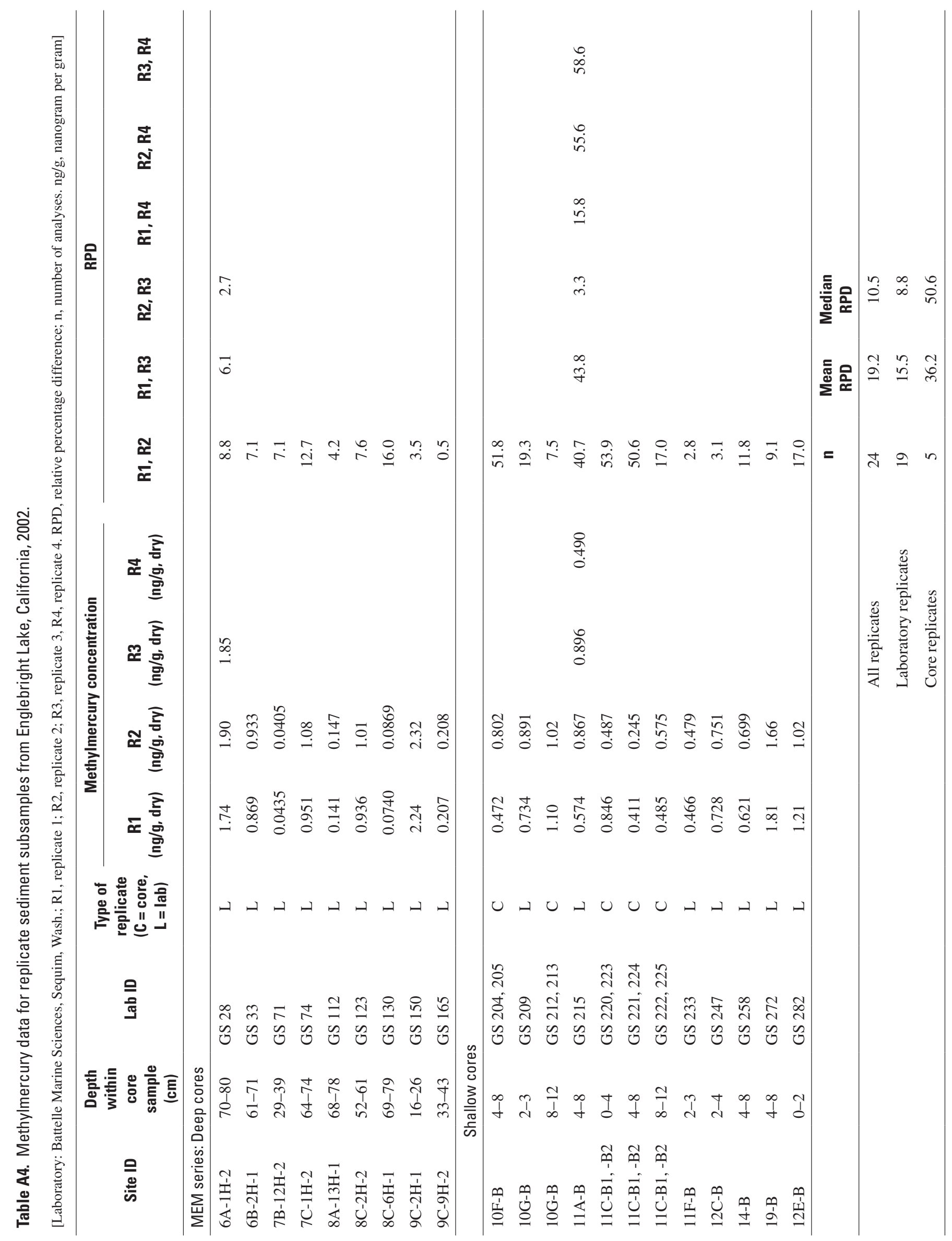


Table A5. Comparison of results from two laboratories for total mercury and methylmercury in split sediment subsamples from Englebright Lake, California, 2002.

[Lab B: Battelle Marine Sciences Laboratory, Sequim, Wash.; Lab C: U.S. Geological Survey Laboratory, Madison, Wisc. ng/g, nanogram per gram; RPD, relative percentage difference; $\%$, percent; - , not determined]

\begin{tabular}{|c|c|c|c|c|c|c|c|c|c|c|}
\hline \multirow[t]{2}{*}{ Lab ID } & \multirow{2}{*}{$\begin{array}{l}\text { Core } \\
\text { section }\end{array}$} & \multirow{2}{*}{$\begin{array}{l}\text { Type of } \\
\text { replicate } \\
\text { (C = core, } \\
\text { L = lab) }\end{array}$} & \multicolumn{2}{|c|}{$\begin{array}{c}\text { Total } \\
\text { mercury } \\
\text { concentration }\end{array}$} & \multirow{2}{*}{$\begin{array}{c}\text { Total } \\
\text { mercury } \\
\text { RPD }\end{array}$} & \multirow{2}{*}{$\begin{array}{c}\text { Total } \\
\text { mercury, } \\
\text { ratio of } \\
\text { concen- } \\
\text { tration } \\
\text { Lab C: } \\
\text { Lab B } \\
(\%)\end{array}$} & \multicolumn{2}{|c|}{$\begin{array}{l}\text { Methylmercury } \\
\text { concentration }\end{array}$} & \multirow{2}{*}{$\begin{array}{l}\text { Methyl- } \\
\text { mercury } \\
\text { RPD }\end{array}$} & \multirow{2}{*}{$\begin{array}{c}\text { Methyl- } \\
\text { mercury, } \\
\text { ratio of } \\
\text { concen- } \\
\text { tration }\end{array}$} \\
\hline & & & $\begin{array}{c}\text { Lab B } \\
\text { (ng/g, dry) }\end{array}$ & $\begin{array}{c}\text { Lab C } \\
\text { (ng/g, dry) }\end{array}$ & & & $\begin{array}{c}\text { Lab B } \\
\text { (ng/g, dry) }\end{array}$ & $\begin{array}{c}\text { Lab C } \\
\text { (ng/g, dry) }\end{array}$ & & \\
\hline GS 20 & 4D-2E-1 & $\mathrm{C}$ & 182 & 204 & 11.6 & 112.4 & 0.579 & 0.412 & 33.8 & 71.1 \\
\hline GS 27 & 4D-6H-1 & $\mathrm{C}$ & 251 & 235 & 6.5 & 93.7 & 0.200 & 0.151 & 28.0 & 75.5 \\
\hline GS 30 & $6 \mathrm{~A}-4 \mathrm{E}-1$ & $\mathrm{C}$ & 539 & 539 & 0.1 & 100.1 & 0.430 & 0.273 & 44.8 & 63.4 \\
\hline GS 36 & 6D-H1-1 & $\mathrm{C}$ & 153 & 173 & 12.3 & 113.1 & 0.348 & 0.313 & 10.5 & 90.1 \\
\hline GS 70 & 7B-12H-1 & $\mathrm{C}$ & 87.7 & 100 & 13.1 & 114.0 & 0.230 & 0.172 & 29.0 & 74.7 \\
\hline GS 101 & $8 \mathrm{~A}-2 \mathrm{H}-2$ & $\mathrm{C}$ & 100 & 89.4 & 11.1 & 89.4 & 0.779 & 0.619 & 22.9 & 79.5 \\
\hline GS 105 & $8 \mathrm{~A}-7 \mathrm{H}-2$ & $\mathrm{C}$ & 37.3 & 42.7 & 13.5 & 114.5 & 0.0626 & $<0.10$ & - & - \\
\hline GS 115 & $8 \mathrm{~A}-14 \mathrm{H}-2$ & $\mathrm{C}$ & 365 & 385 & 5.3 & 105.4 & 0.236 & 0.142 & 49.9 & 60.0 \\
\hline GS 134 & $9 \mathrm{~A}-1 \mathrm{H}-2$ & $\mathrm{C}$ & 216 & 257 & 17.3 & 118.9 & 1.66 & 1.13 & 38.3 & 67.9 \\
\hline GS 140 & $9 \mathrm{~A}-5 \mathrm{H}-1$ & $\mathrm{C}$ & 12.0 & 40.7 & 109.0 & 339.5 & 0.0245 & $<0.0941$ & - & - \\
\hline \multirow[t]{2}{*}{ GS 147} & $9 \mathrm{~A}-11 \mathrm{H}-1$ & $\mathrm{C}$ & 65.5 & 57.5 & 13.0 & 87.8 & 0.0356 & $<0.13$ & - & - \\
\hline & & & & mean & 12.1 & 100.7 & & mean & 27.5 & 76.4 \\
\hline
\end{tabular}




\section{Appendix B. Quality Assurance, Quality Control, and Data Tables for Trace and Major Elements}

Table B1. Concentrations of trace metals and major elements in standard reference materials.

[Standard reference material is Buffalo River Sediment (NIST 2704). NIST, National Institute of Standards and Technology. Wt\%, weight percent; Avg, average concentration from three or more replicate measurements of single digestate; SD, standard deviation. $\mu \mathrm{g} / \mathrm{g}$, microgram per gram; na, not applicable; <, less than.

Standard deviation for each analysis represents standard deviation of three or more ICP (inductively coupled plasma) analyses of single digestate. Standard deviation on "Overall average" row represents standard deviation of individual analyses. Recovery computed as Average value divided by Certified value]

\begin{tabular}{|c|c|c|c|c|c|c|c|c|c|c|c|c|}
\hline \multirow[t]{2}{*}{$\begin{array}{c}\text { Laboratory } \\
\text { ID }\end{array}$} & \multicolumn{2}{|c|}{$\begin{array}{c}\text { Aluminum } \\
\text { Al } \\
\mathbf{W t} \%\end{array}$} & \multicolumn{2}{|c|}{$\begin{array}{c}\text { Arsenic } \\
\text { As } \\
\mu g / g\end{array}$} & \multicolumn{2}{|c|}{$\begin{array}{c}\text { Barium } \\
\text { Ba } \\
\mu \mathrm{g} / \mathrm{g}\end{array}$} & \multicolumn{2}{|c|}{$\begin{array}{c}\text { Beryllium } \\
\text { Be } \\
\mu \mathrm{g} / \mathrm{g}\end{array}$} & \multicolumn{2}{|c|}{$\begin{array}{c}\text { Bismuth } \\
\text { Bi } \\
\mu g / g\end{array}$} & \multicolumn{2}{|c|}{$\begin{array}{c}\text { Calcium } \\
\text { Ca } \\
\text { Wt } \%\end{array}$} \\
\hline & Avg & SD & Avg & SD & Avg & SD & Avg & SD & Avg & SD & Avg & SD \\
\hline 23515 & 5.3 & 0.1 & 22 & 1 & 378 & 33 & 1.8 & 0.0 & 0.56 & 0.02 & 2.3 & 0.0 \\
\hline 23529 & 6.1 & 0.2 & 22 & 1 & 396 & 13 & 1.7 & 0.0 & 0.58 & 0.03 & 2.5 & 0.0 \\
\hline 23627 & 3.0 & 0.2 & 22 & 0 & 343 & 7 & 2.0 & 0.0 & 0.64 & 0.00 & 2.2 & 0.0 \\
\hline 23760 & 2.7 & 0.1 & 21 & 1 & 304 & 11 & 1.9 & 0.0 & 0.52 & 0.07 & 1.6 & 0.0 \\
\hline 23771 & 2.5 & 0.2 & 21 & 1 & 301 & 9 & 1.9 & 0.0 & 0.56 & 0.02 & 1.8 & 0.0 \\
\hline 24027 & 3.3 & 0.1 & 22 & 1 & 300 & 21 & 1.8 & 0.2 & 0.86 & 0.03 & 1.5 & 0.0 \\
\hline 24082 & 5.6 & 0.1 & 22 & 1 & 398 & 16 & 1.7 & 0.2 & 0.62 & 0.00 & 2.4 & 0.0 \\
\hline 24088 & 4.5 & 0.1 & 21 & 1 & 339 & 39 & 1.7 & 0.1 & 0.59 & 0.03 & 2.4 & 0.2 \\
\hline 24094 & 3.4 & 0.2 & 21 & 1 & 281 & 21 & 1.7 & 0.0 & 0.71 & 0.00 & 2.1 & 0.1 \\
\hline 24122 & 3.4 & 0.3 & 21 & 1 & 256 & 15 & 1.8 & 0.1 & 0.58 & 0.03 & 1.5 & 0.0 \\
\hline 24128 & 3.4 & 0.2 & 21 & 2 & 265 & 18 & 1.8 & 0.0 & 0.59 & 0.04 & 1.6 & 0.1 \\
\hline 24134 & 4.2 & 0.2 & 24 & 3 & 287 & 13 & 1.8 & 0.1 & 0.63 & 0.02 & 2.0 & 0.1 \\
\hline 24167 & 3.7 & 0.1 & 22 & 1 & 282 & 1 & 1.7 & 0.0 & 0.64 & 0.03 & 2.3 & 0.0 \\
\hline 24173 & 5.0 & 0.2 & 21 & 2 & 348 & 12 & 2.0 & 0.0 & 0.73 & 0.00 & 2.2 & 0.1 \\
\hline Recovery (\%) & 59.4 & na & 291.4 & na & 74.2 & na & na & na & na & na & 73.4 & na \\
\hline
\end{tabular}

${ }^{1}$ Non-bold numbers are not certified and are provided for information only (National Institute of Standards and Technology, 1990).

${ }^{2}$ The National Institute of Standards and Technology (2000) indicated that the orginally certified concentration for arsenic (23.4 $\left.\mu \mathrm{g} / \mathrm{g}\right)$ was too high by about $6 \%$ in analyses made since 1996 . Therefore, the concentration at the time of this study was about $22 \mu \mathrm{g} / \mathrm{g}$ and the corresponding recovery was $95.5 \%$. 
Table B1. Concentrations of trace metals and major elements in standard reference materials_-Continued.

[Standard reference material is Buffalo River Sediment (NIST 2704). NIST, National Institute of Standards and Technology. Wt\%, weight percent; Avg, average concentration from three or more replicate measurements of single digestate; SD, standard deviation. $\mu \mathrm{g} / \mathrm{g}$, microgram per gram; na, not applicable; <, less than.

Standard deviation for each analysis represents standard deviation of three or more ICP (inductively coupled plasma) analyses of single digestate. Standard deviation on "Overall average" row represents standard deviation of individual analyses. Recovery computed as Average value divided by Certified value]

\begin{tabular}{|c|c|c|c|c|c|c|c|c|c|c|c|c|}
\hline \multirow[t]{2}{*}{$\begin{array}{c}\text { Laboratory } \\
\text { ID }\end{array}$} & \multicolumn{2}{|c|}{$\begin{array}{c}\text { Cadmium } \\
\text { Cd } \\
\mu g / g\end{array}$} & \multicolumn{2}{|c|}{$\begin{array}{c}\text { Cerium } \\
\text { Ce } \\
\mu \mathrm{g} / \mathrm{g}\end{array}$} & \multicolumn{2}{|c|}{$\begin{array}{c}\text { Cobalt } \\
\text { Co } \\
\mu \mathrm{g} / \mathrm{g}\end{array}$} & \multicolumn{2}{|c|}{$\begin{array}{c}\text { Chromium } \\
\mathrm{Cr} \\
\mu \mathrm{g} / \mathrm{g}\end{array}$} & \multicolumn{2}{|c|}{$\begin{array}{c}\text { Cesium } \\
\text { Cs } \\
\mu \mathrm{g} / \mathrm{g}\end{array}$} & \multicolumn{2}{|c|}{$\begin{array}{c}\text { Copper } \\
\text { Cu } \\
\mu \mathrm{g} / \mathrm{g}\end{array}$} \\
\hline & Avg & SD & Avg & SD & Avg & SD & Avg & SD & Avg & SD & Avg & SD \\
\hline 23515 & 3.7 & 0.0 & 52 & 3 & 13 & 1 & 130 & 6 & 5.4 & 0.1 & 99 & 3 \\
\hline 23529 & 3.3 & 0.1 & 55 & 4 & 13 & 0 & 121 & 8 & 6.0 & 0.1 & 98 & 1 \\
\hline 23627 & 3.4 & 0.1 & 27 & 2 & 13 & 0 & 126 & 3 & 4.0 & 0.0 & 99 & 1 \\
\hline 23760 & 3.5 & 0.2 & 16 & 3 & 13 & 0 & 121 & 3 & 1.8 & 0.0 & 96 & 4 \\
\hline 23771 & 3.5 & 0.2 & 16 & 0 & 13 & 0 & 126 & 3 & 1.4 & 0.0 & 100 & 0 \\
\hline 24072 & 3.4 & 0.1 & 19 & 0 & 12 & 1 & 130 & 6 & 2.7 & 0.0 & 95 & 4 \\
\hline 24082 & 3.3 & 0.1 & 58 & 1 & 12 & 0 & 121 & 4 & 5.3 & 0.2 & 98 & 0 \\
\hline 24088 & 3.5 & 0.2 & 45 & 2 & 12 & 0 & 120 & 0 & 4.0 & 0.1 & 94 & 1 \\
\hline 24094 & 3.4 & 0.2 & 27 & 1 & 12 & 1 & 119 & 0 & 3.1 & 0.0 & 90 & 0 \\
\hline 24122 & 3.3 & 0.2 & 31 & 2 & 12 & 1 & 115 & 2 & 2.9 & 0.2 & 87 & 1 \\
\hline 24128 & 3.3 & 0.0 & 29 & 2 & 11 & 0 & 115 & 1 & 2.6 & 0.1 & 90 & 2 \\
\hline 24134 & 3.3 & 0.1 & 41 & 0 & 12 & 1 & 125 & 3 & 5.4 & 0.0 & 99 & 2 \\
\hline 24167 & 3.3 & 0.1 & 30 & 1 & 12 & 0 & 130 & 3 & 3.6 & 0.0 & 98 & 1 \\
\hline Certified value $^{1}$ & 3.45 & 0.22 & 72 & na & 14.0 & 0.6 & 135 & 5 & 6 & na & 98.6 & 5.0 \\
\hline Recovery (\%) & 98.8 & na & 41.7 & na & 88.2 & na & 92.3 & na & 59.7 & na & 98.1 & na \\
\hline
\end{tabular}


Table B1. Concentrations of trace metals and major elements in standard reference materials-Continued.

[Standard reference material is Buffalo River Sediment (NIST 2704). NIST, National Institute of Standards and Technology. Wt\%, weight percent; Avg, average concentration from three or more replicate measurements of single digestate; SD, standard deviation. $\mu \mathrm{g} / \mathrm{g}$, microgram per gram; na, not applicable; <, less than.

Standard deviation for each analysis represents standard deviation of three or more ICP (inductively coupled plasma) analyses of single digestate. Standard deviation on "Overall average" row represents standard deviation of individual analyses. Recovery computed as Average value divided by Certified value]

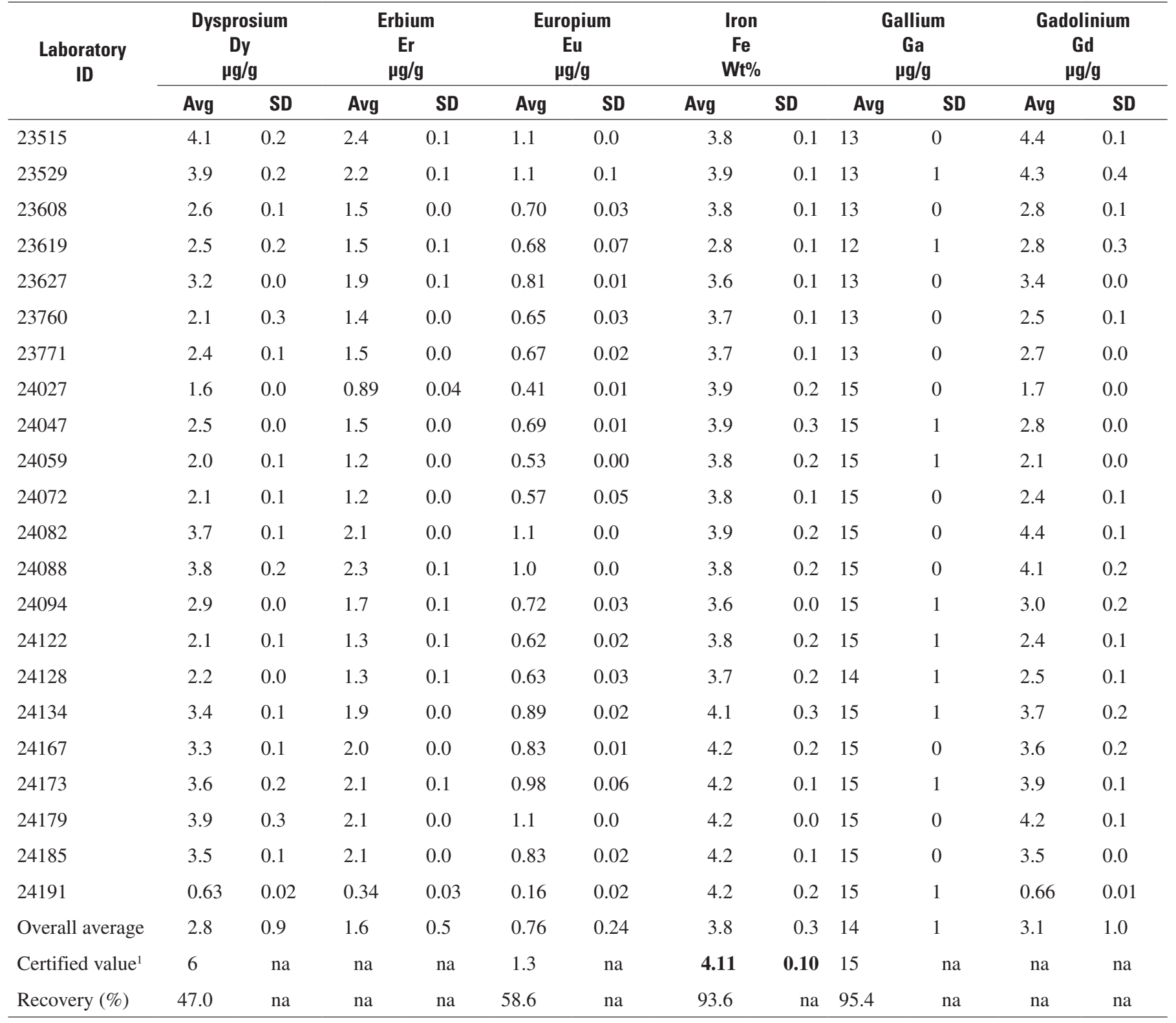

${ }^{1}$ Non-bold numbers are not certified and are provided for information only (National Institute of Standards and Technology, 1990) 
Table B1. Concentrations of trace metals and major elements in standard reference materials_Continued.

[Standard reference material is Buffalo River Sediment (NIST 2704). NIST, National Institute of Standards and Technology. Wt\%, weight percent; Avg, average concentration from three or more replicate measurements of single digestate; SD, standard deviation. $\mu \mathrm{g} / \mathrm{g}$, microgram per gram; na, not applicable; <, less than.

Standard deviation for each analysis represents standard deviation of three or more ICP (inductively coupled plasma) analyses of single digestate. Standard deviation on "Overall average" row represents standard deviation of individual analyses. Recovery computed as Average value divided by Certified value]

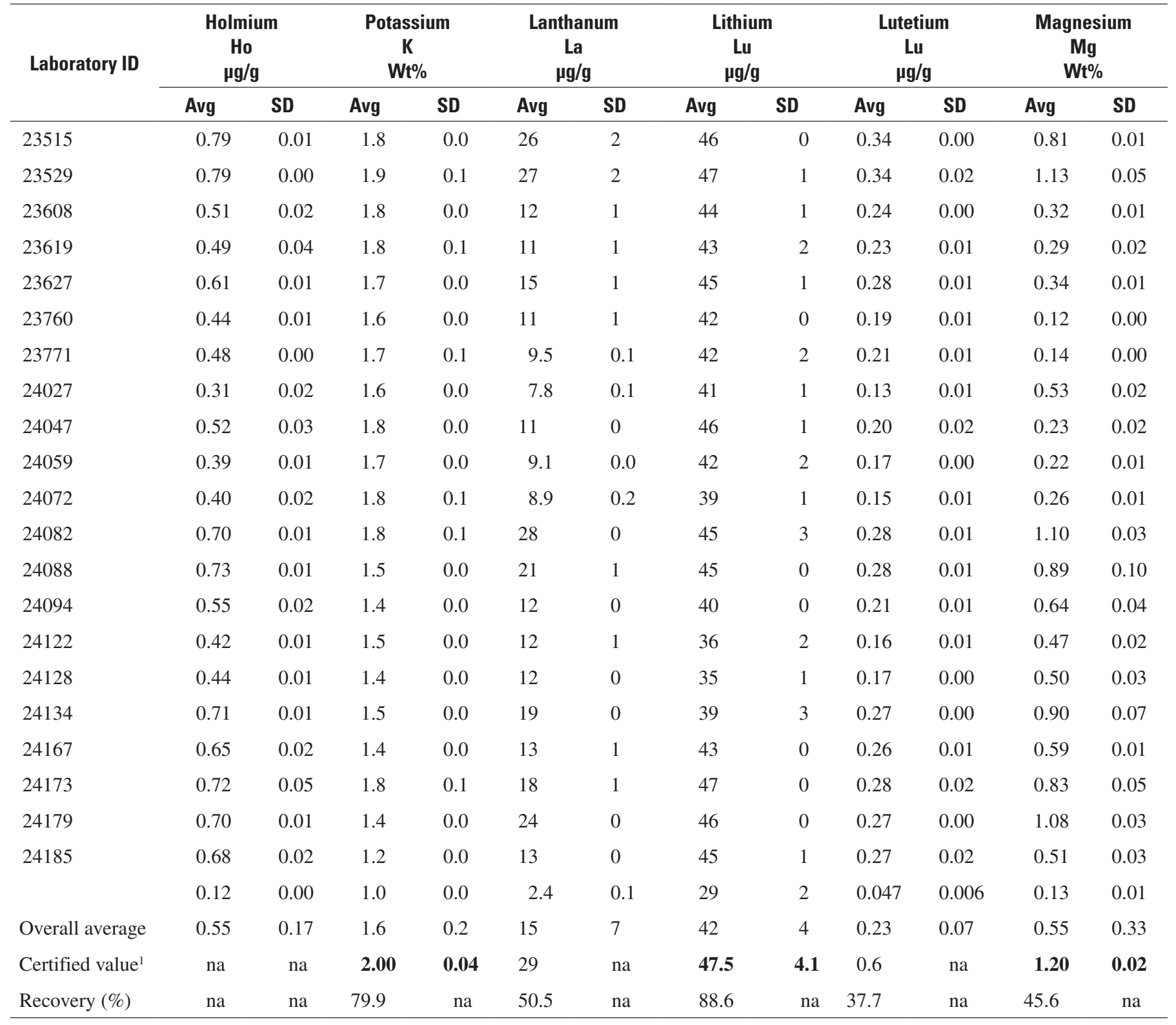

${ }^{1}$ Non-bold numbers are not certified and are provided for information only (National Institute of Standards and Technology, 1990). 
Table B1. Concentrations of trace metals and major elements in standard reference materials-Continued.

[Standard reference material is Buffalo River Sediment (NIST 2704). NIST, National Institute of Standards and Technology. Wt\%, weight percent; Avg, average concentration from three or more replicate measurements of single digestate; SD, standard deviation. $\mu \mathrm{g} / \mathrm{g}$, microgram per gram; na, not applicable; <, less than.

Standard deviation for each analysis represents standard deviation of three or more ICP (inductively coupled plasma) analyses of single digestate. Standard deviation on "Overall average" row represents standard deviation of individual analyses. Recovery computed as Average value divided by Certified value]

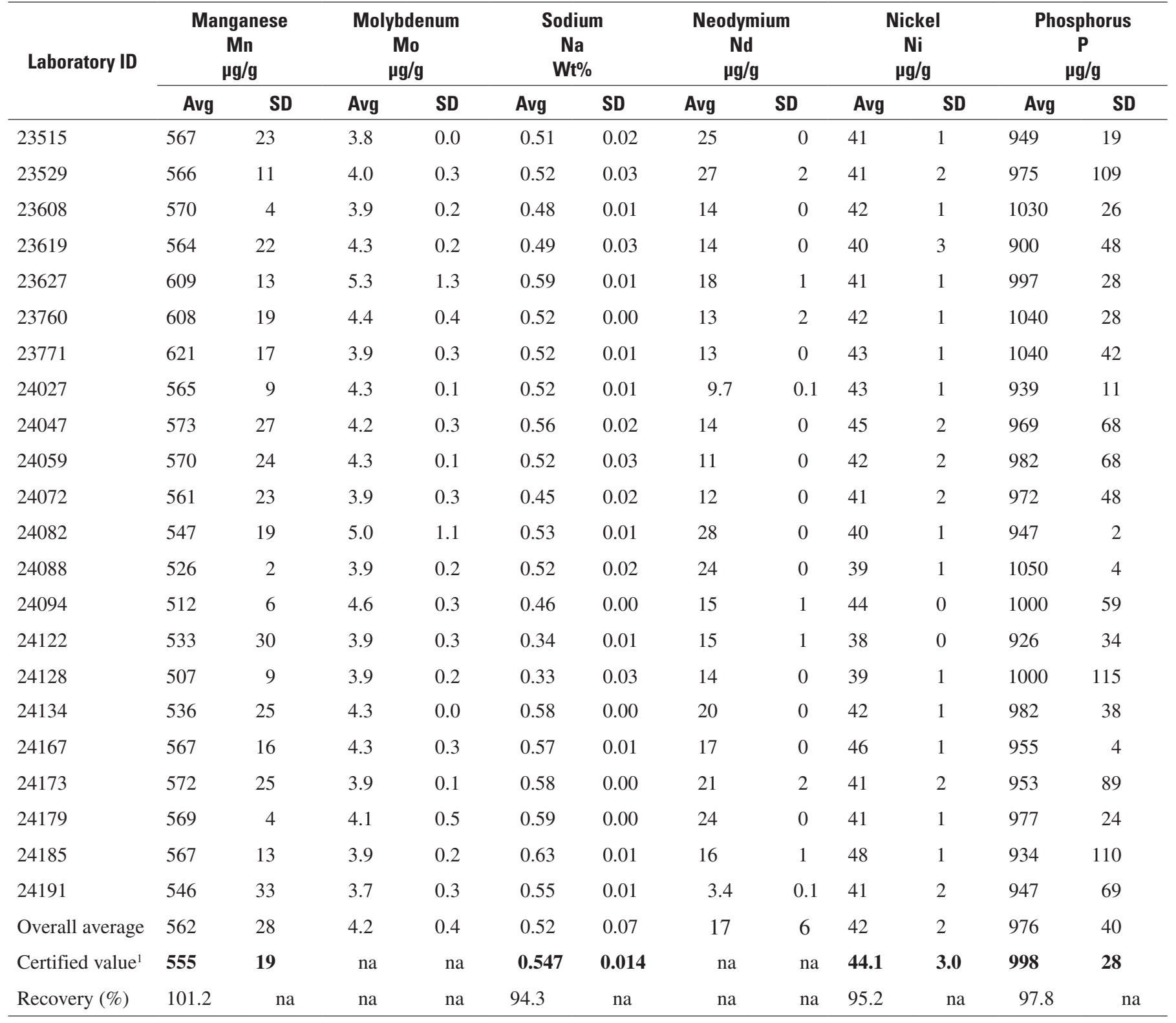

\footnotetext{
${ }^{1}$ Non-bold numbers are not certified and are provided for information only (National Institute of Standards and Technology, 1990).
} 
Table B1. Concentrations of trace metals and major elements in standard reference materials-Continued.

[Standard reference material is Buffalo River Sediment (NIST 2704). NIST, National Institute of Standards and Technology. Wt\%, weight percent; Avg, average concentration from three or more replicate measurements of single digestate; SD, standard deviation. $\mu \mathrm{g} / \mathrm{g}$, microgram per gram; na, not applicable; <, less than.

Standard deviation for each analysis represents standard deviation of three or more ICP (inductively coupled plasma) analyses of single digestate. Standard deviation on "Overall average" row represents standard deviation of individual analyses. Recovery computed as Average value divided by Certified value]

\begin{tabular}{|c|c|c|c|c|c|c|c|c|c|c|c|c|}
\hline \multirow[t]{2}{*}{$\begin{array}{c}\text { Laboratory } \\
\text { ID }\end{array}$} & \multicolumn{2}{|c|}{$\begin{array}{l}\text { Lead } \\
\mathrm{Pb} \\
\mu \mathrm{g} / \mathrm{g}\end{array}$} & \multicolumn{2}{|c|}{$\begin{array}{c}\text { Praseodymium } \\
\mathrm{Pr} \\
\mu \mathrm{g} / \mathrm{g}\end{array}$} & \multicolumn{2}{|c|}{$\begin{array}{c}\text { Rubidium } \\
\text { Rb } \\
\mu \mathrm{g} / \mathrm{g}\end{array}$} & \multicolumn{2}{|c|}{$\begin{array}{c}\text { Rhenium } \\
\text { Re } \\
\mu \mathrm{g} / \mathrm{g}\end{array}$} & \multicolumn{2}{|c|}{$\begin{array}{c}\text { Sulfur } \\
\text { S } \\
\mathbf{W t} \%\end{array}$} & \multicolumn{2}{|c|}{$\begin{array}{c}\text { Antimony } \\
\mathrm{Sb} \\
\mu \mathrm{g} / \mathrm{g}\end{array}$} \\
\hline & Avg & SD & Avg & SD & Avg & SD & Avg & SD & Avg & SD & Avg & SD \\
\hline 23515 & 160 & 1 & 6.6 & 0.4 & 71 & 1 & $<0.002$ & 0.001 & 0.42 & 0.01 & 3.7 & 0.1 \\
\hline 23529 & 168 & 1 & 6.8 & 0.5 & 103 & 7 & $<0.002$ & 0.000 & 0.44 & 0.01 & 3.8 & 0.3 \\
\hline 23627 & 162 & 2 & 4.3 & 0.0 & 35 & 1 & 0.003 & 0.0008 & 0.42 & 0.01 & 5.2 & 0.1 \\
\hline 23760 & 153 & 5 & 3.3 & 0.1 & 37 & 3 & $<0.002$ & 0.000 & 0.46 & 0.01 & 3.6 & 0.1 \\
\hline 23771 & 151 & 5 & 3.2 & 0.0 & 27 & 1 & 0.0027 & 0.0001 & 0.45 & 0.00 & 3.8 & 0.1 \\
\hline 24072 & 216 & 5 & 2.9 & 0.1 & 42 & 2 & 0.003 & 0.000 & 0.43 & 0.02 & 3.9 & 0.2 \\
\hline 24082 & 154 & 2 & 7.0 & 0.2 & 106 & 1 & 0.003 & 0.002 & 0.42 & 0.02 & 3.8 & 0.1 \\
\hline 24088 & 154 & 1 & 5.7 & 0.3 & 24 & 1 & $<0.002$ & 0.002 & 0.43 & 0.05 & 3.7 & 0.2 \\
\hline 24094 & 156 & 0 & 3.7 & 0.0 & 15 & 1 & 0.004 & 0.001 & 0.43 & 0.03 & 3.9 & 0.1 \\
\hline 24122 & 150 & 10 & 3.6 & 0.3 & 45 & 4 & 0.003 & 0.002 & 0.40 & 0.03 & 3.4 & 0.1 \\
\hline 24128 & 156 & 2 & 3.5 & 0.2 & 31 & 1 & 0.003 & 0.001 & 0.40 & 0.02 & 3.7 & 0.0 \\
\hline 24134 & 153 & 8 & 5.0 & 0.1 & 67 & 2 & 0.003 & 0.002 & 0.43 & 0.02 & 3.6 & 0.1 \\
\hline 24167 & 155 & 8 & 3.9 & 0.1 & 16 & 0 & 0.005 & 0.000 & 0.44 & 0.02 & 3.6 & 0.0 \\
\hline Certified value $^{1}$ & 161 & 17 & na & na & 100 & na & na & na & 0.397 & 0.004 & 3.79 & 0.15 \\
\hline Recovery (\%) & 99.8 & na & na & na & 45.2 & na & na & na & 109.0 & na & 100.9 & na \\
\hline
\end{tabular}

${ }^{1}$ Non-bold numbers are not certified and are provided for information only (National Institute of Standards and Technology, 1990). 
Table B1. Concentrations of trace metals and major elements in standard reference materials-Continued.

[Standard reference material is Buffalo River Sediment (NIST 2704). NIST, National Institute of Standards and Technology. Wt\%, weight percent; Avg, average concentration from three or more replicate measurements of single digestate; SD, standard deviation. $\mu \mathrm{g} / \mathrm{g}$, microgram per gram; na, not applicable; <, less than.

Standard deviation for each analysis represents standard deviation of three or more ICP (inductively coupled plasma) analyses of single digestate. Standard deviation on "Overall average" row represents standard deviation of individual analyses. Recovery computed as Average value divided by Certified value]

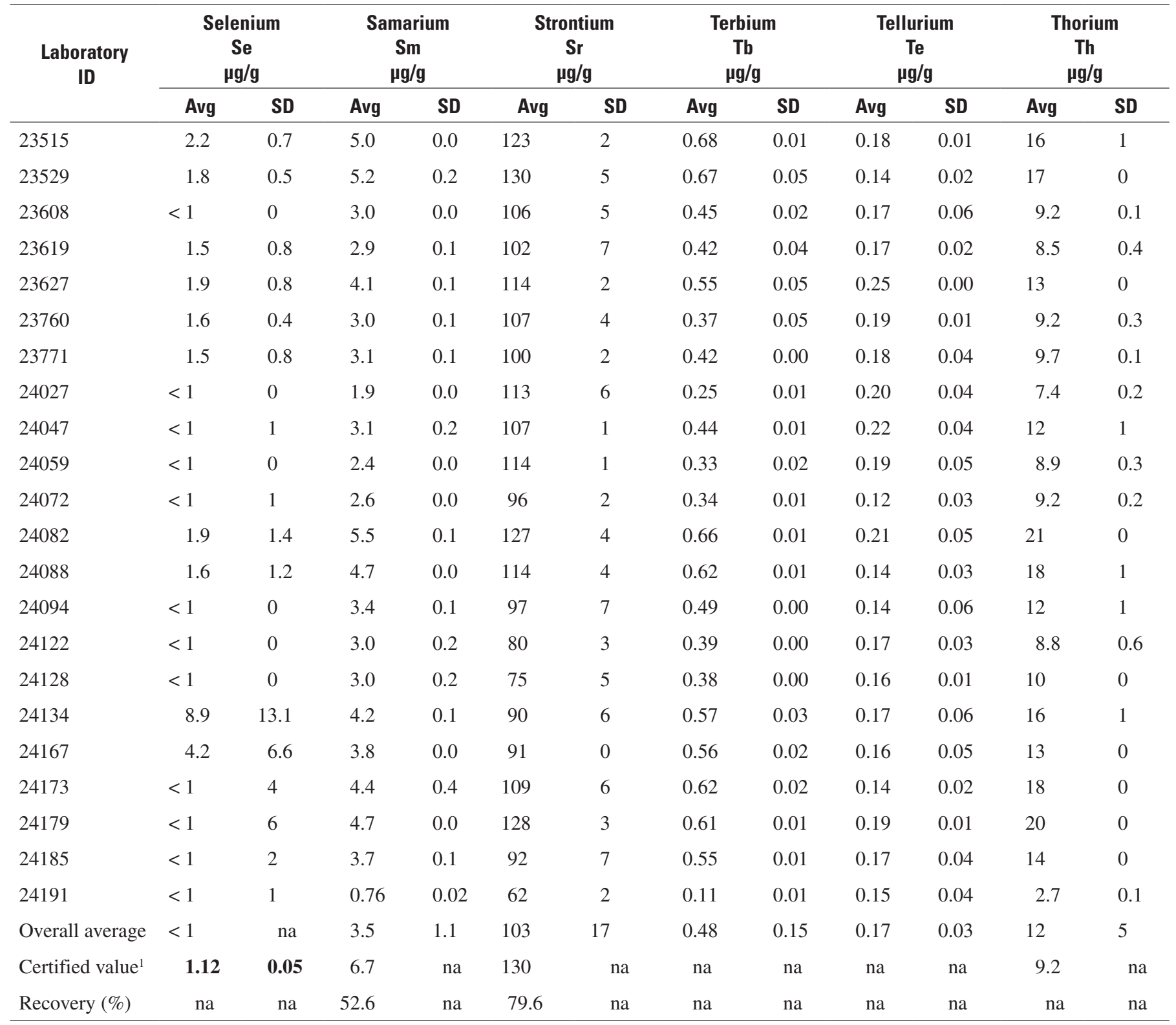

\footnotetext{
${ }^{1}$ Non-bold numbers are not certified and are provided for information only (National Institute of Standards and Technology, 1990).
} 
Table B1. Concentrations of trace metals and major elements in standard reference materials_-Continued.

[Standard reference material is Buffalo River Sediment (NIST 2704). NIST, National Institute of Standards and Technology. Wt\%, weight percent; Avg, average concentration from three or more replicate measurements of single digestate; SD, standard deviation. $\mu \mathrm{g} / \mathrm{g}$, microgram per gram; na, not applicable; <, less than.

Standard deviation for each analysis represents standard deviation of three or more ICP (inductively coupled plasma) analyses of single digestate. Standard deviation on "Overall average" row represents standard deviation of individual analyses. Recovery computed as Average value divided by Certified value]

\begin{tabular}{|c|c|c|c|c|c|c|c|c|c|c|c|c|}
\hline \multirow[t]{2}{*}{$\begin{array}{c}\text { Laboratory } \\
\text { ID }\end{array}$} & \multicolumn{2}{|c|}{$\begin{array}{c}\text { Titanium } \\
\mathbf{T i} \\
\mathbf{W t} \%\end{array}$} & \multicolumn{2}{|c|}{$\begin{array}{c}\text { Thallium } \\
\text { TI } \\
\mu \mathrm{g} / \mathrm{g}\end{array}$} & \multicolumn{2}{|c|}{$\begin{array}{l}\text { Thulium } \\
\text { Tm } \\
\mu \mathrm{g} / \mathrm{g}\end{array}$} & \multicolumn{2}{|c|}{$\begin{array}{c}\text { Uranium } \\
\mathbf{U} \\
\mu \mathrm{g} / \mathrm{g}\end{array}$} & \multicolumn{2}{|c|}{$\begin{array}{c}\text { Vanadium } \\
\mathbf{V} \\
\mu \mathrm{g} / \mathrm{g}\end{array}$} & \multicolumn{2}{|c|}{$\begin{array}{c}\text { Tungsten } \\
\mathbf{W} \\
\mu \mathrm{g} / \mathrm{g}\end{array}$} \\
\hline & Avg & SD & Avg & SD & Avg & SD & Avg & SD & Avg & SD & Avg & SD \\
\hline 23515 & 0.43 & 0.03 & 0.97 & 0.16 & 0.34 & 0.00 & 3.0 & 0.1 & 91 & 3 & 1.6 & 0.0 \\
\hline 23529 & 0.42 & 0.01 & 0.87 & 0.03 & 0.33 & 0.00 & 2.9 & 0.1 & 90 & 4 & 1.5 & 0.1 \\
\hline 23608 & 0.45 & 0.02 & 0.80 & 0.01 & 0.22 & 0.01 & 3.0 & 0.0 & 94 & 4 & 1.6 & 0.1 \\
\hline 23619 & 0.44 & 0.03 & 0.78 & 0.03 & 0.22 & 0.01 & 3.1 & 0.1 & 93 & 6 & 1.8 & 0.1 \\
\hline 23627 & 0.44 & 0.02 & 0.88 & 0.08 & 0.27 & 0.01 & 3.0 & 0.1 & 92 & 2 & 1.6 & 0.1 \\
\hline 23760 & 0.44 & 0.01 & 0.85 & 0.02 & 0.19 & 0.00 & 3.0 & 0.0 & 90 & 5 & 2.0 & 0.1 \\
\hline 23771 & 0.44 & 0.01 & 0.79 & 0.01 & 0.21 & 0.00 & 3.0 & 0.2 & 91 & 3 & 1.6 & 0.1 \\
\hline 24027 & 0.43 & 0.01 & 0.85 & 0.07 & 0.12 & 0.00 & 3.0 & 0.1 & 92 & 3 & 1.7 & 0.1 \\
\hline 24047 & 0.45 & 0.01 & 0.89 & 0.02 & 0.21 & 0.01 & 3.1 & 0.1 & 95 & 3 & 1.6 & 0.0 \\
\hline 24059 & 0.45 & 0.02 & 0.89 & 0.03 & 0.16 & 0.00 & 3.0 & 0.1 & 96 & 5 & 1.5 & 0.1 \\
\hline 24072 & 0.43 & 0.02 & 0.84 & 0.02 & 0.17 & 0.00 & 2.9 & 0.1 & 92 & 3 & 1.9 & 0.0 \\
\hline 24082 & 0.34 & 0.01 & 0.84 & 0.07 & 0.29 & 0.01 & 2.8 & 0.2 & 90 & 1 & 1.4 & 0.0 \\
\hline 24088 & 0.44 & 0.05 & 0.85 & 0.11 & 0.32 & 0.00 & 3.0 & 0.1 & 95 & 11 & 1.6 & 0.1 \\
\hline 24094 & 0.45 & 0.01 & 0.85 & 0.05 & 0.23 & 0.00 & 3.1 & 0.1 & 100 & 1 & 1.6 & 0.1 \\
\hline 24122 & 0.39 & 0.02 & 0.80 & 0.08 & 0.17 & 0.02 & 2.9 & 0.1 & 91 & 5 & 1.5 & 0.0 \\
\hline 24128 & 0.40 & 0.03 & 0.83 & 0.04 & 0.18 & 0.01 & 2.8 & 0.0 & 90 & 7 & 1.5 & 0.0 \\
\hline 24134 & 0.40 & 0.02 & 1.0 & 0.3 & 0.28 & 0.00 & 2.7 & 0.1 & 91 & 7 & 1.7 & 0.0 \\
\hline 24167 & 0.41 & 0.00 & 0.83 & 0.03 & 0.28 & 0.01 & 2.8 & 0.0 & 91 & 0 & 1.6 & 0.0 \\
\hline 24173 & 0.39 & 0.02 & 0.86 & 0.10 & 0.29 & 0.01 & 3.0 & 0.0 & 89 & 5 & 1.5 & 0.1 \\
\hline 24179 & 0.36 & 0.01 & 0.85 & 0.02 & 0.30 & 0.01 & 2.9 & 0.1 & 93 & 5 & 1.3 & 0.0 \\
\hline 24185 & 0.42 & 0.03 & 0.81 & 0.07 & 0.28 & 0.01 & 3.1 & 0.1 & 94 & 7 & 1.5 & 0.1 \\
\hline 24191 & 0.42 & 0.02 & 0.74 & 0.05 & 0.052 & 0.002 & 2.9 & 0.2 & 92 & 3 & 1.5 & 0.1 \\
\hline Overall average & 0.42 & 0.03 & 0.85 & 0.06 & 0.23 & 0.07 & 3.0 & 0.1 & 92 & 3 & 1.6 & 0.1 \\
\hline Certified value & 0.457 & 0.018 & 1.06 & 0.07 & na & na & 3.13 & 0.13 & 95 & 4 & na & $\mathrm{n}$ \\
\hline Recovery (\%) & 92.0 & na & 80.1 & na & na & na & 94.3 & na & 97.1 & na & na & $\mathrm{n}$ \\
\hline
\end{tabular}

${ }^{1}$ Non-bold numbers are not certified and are provided for information only (National Institute of Standards and Technology, 1990). 
Table B1. Concentrations of trace metals and major elements in standard reference materials—Continued.

[Standard reference material is Buffalo River Sediment (NIST 2704). NIST, National Institute of Standards and Technology.

$\mathrm{Wt} \%$, weight percent; Avg, average concentration from three or more replicate measurements of single digestate; SD, standard deviation. $\mu \mathrm{g} / \mathrm{g}$, microgram per gram; na, not applicable; <, less than.

Standard deviation for each analysis represents standard deviation of three or more ICP (inductively coupled plasma) analyses of single digestate. Standard deviation on "Overall average" row represents standard deviation of individual analyses. Recovery computed as Average value divided by Certified value]

\begin{tabular}{|c|c|c|c|c|c|c|c|c|}
\hline \multirow[t]{2}{*}{$\begin{array}{l}\text { Laboratory } \\
\text { ID }\end{array}$} & \multicolumn{2}{|c|}{$\begin{array}{c}\text { Yttrium } \\
Y \\
\mu g / g\end{array}$} & \multicolumn{2}{|c|}{$\begin{array}{c}\text { Ytterbium } \\
\mathrm{Yb} \\
\mu \mathrm{g} / \mathrm{g}\end{array}$} & \multicolumn{2}{|c|}{$\begin{array}{c}\text { Zinc } \\
\text { Zn } \\
\mu \mathrm{g} / \mathrm{g}\end{array}$} & \multicolumn{2}{|c|}{$\begin{array}{c}\text { Zirconium } \\
\mathrm{Zr} \\
\mu \mathrm{g} / \mathrm{g}\end{array}$} \\
\hline & Avg & SD & Avg & SD & Avg & SD & Avg & SD \\
\hline 23515 & 23 & 1 & 2.4 & 0.0 & 410 & 10 & 152 & 5 \\
\hline 23529 & 20 & 0 & 2.2 & 0.1 & 407 & 17 & 136 & 9 \\
\hline 23608 & 14 & 0 & 1.5 & 0.0 & 414 & 2 & 151 & 6 \\
\hline 23619 & 13 & 1 & 1.5 & 0.1 & 409 & 18 & 151 & 11 \\
\hline 23627 & 16 & 0 & 1.9 & 0.0 & 413 & 1 & 179 & 4 \\
\hline 23760 & 11 & 0 & 1.2 & 0.0 & 443 & 1 & 172 & 6 \\
\hline 23771 & 11 & 0 & 1.4 & 0.0 & 428 & 0 & 166 & 2 \\
\hline 24027 & 7.5 & 0.1 & 0.88 & 0.04 & 412 & 2 & 164 & 7 \\
\hline 24047 & 13 & 1 & 1.5 & 0.1 & 444 & 6 & 158 & 11 \\
\hline 24059 & 11 & 0 & 1.1 & 0.0 & 470 & 6 & 161 & 8 \\
\hline 24072 & 9.3 & 0.4 & 1.1 & 0.0 & 416 & 14 & 147 & 7 \\
\hline 24082 & 20 & 0 & 2.1 & 0.1 & 407 & 0 & 121 & 1 \\
\hline 24088 & 20 & 0 & 2.2 & 0.1 & 399 & 4 & 146 & 1 \\
\hline 24094 & 13 & 1 & 1.6 & 0.1 & 395 & 2 & 142 & 1 \\
\hline 24122 & 8.7 & 0.5 & 1.2 & 0.1 & 393 & 0 & 123 & 7 \\
\hline 24128 & 10 & 1 & 1.3 & 0.0 & 397 & 3 & 133 & 2 \\
\hline 24134 & 17 & 1 & 1.9 & 0.0 & 413 & 8 & 138 & 4 \\
\hline 24167 & 16 & 1 & 2.1 & 0.0 & 411 & 3 & 173 & 5 \\
\hline 24173 & 17 & 1 & 2.1 & 0.0 & 422 & 21 & 146 & 8 \\
\hline 24179 & 19 & 0 & 2.0 & 0.0 & 415 & 11 & 132 & 3 \\
\hline 24185 & 17 & 0 & 2.0 & 0.0 & 410 & 7 & 185 & 1 \\
\hline 24191 & 2.6 & 0.2 & 0.37 & 0.02 & 417 & 4 & 164 & 7 \\
\hline Overall average & 14 & 5 & 1.6 & 0.5 & 416 & 18 & 152 & 18 \\
\hline Certified value & na & na & 2.8 & na & 438 & 12 & 300 & na \\
\hline Recovery (\%) & na & na & 58.0 & na & 94.9 & na & 50.6 & na \\
\hline
\end{tabular}

${ }^{1}$ Non-bold numbers are not certified and are provided for information only (National Institute of Standards and Technology, 1990). 
Table B2. Data for trace metals and major elements in digestion blanks.

[Averages (Avg) and standard deviations (SD) are for three or more replicate analyses of single digested subsample. Standard deviation for each analysis represents standard deviation of three or more ICP (inductively coupled plasma) analyses of single digestate. $\mu \mathrm{g} / \mathrm{L}$, microgram per liter; mg/L, milligram per liter;

$<$, less than]

\begin{tabular}{|c|c|c|c|c|c|c|c|c|c|c|c|c|}
\hline \multirow[t]{2}{*}{$\begin{array}{c}\text { Laboratory } \\
\text { ID }\end{array}$} & \multicolumn{2}{|c|}{$\begin{array}{c}\text { Aluminum } \\
\text { Al } \\
\mu \mathrm{g} / \mathrm{L}\end{array}$} & \multicolumn{2}{|c|}{$\begin{array}{c}\text { Arsenic } \\
\text { As } \\
\mu \mathrm{g} / \mathrm{L}\end{array}$} & \multicolumn{2}{|c|}{$\begin{array}{c}\text { Barium } \\
\text { Ba } \\
\mu \mathrm{g} / \mathrm{L}\end{array}$} & \multicolumn{2}{|c|}{$\begin{array}{c}\text { Beryllium } \\
\text { Be } \\
\mu \mathrm{g} / \mathrm{L} \\
\end{array}$} & \multicolumn{2}{|c|}{$\begin{array}{c}\text { Bismuth } \\
\mathrm{Bi} \\
\mu \mathrm{g} / \mathrm{L}\end{array}$} & \multicolumn{2}{|c|}{$\begin{array}{c}\text { Calcium } \\
\mathrm{Ca} \\
\mathrm{mg} / \mathrm{L}\end{array}$} \\
\hline & Avg & SD & Avg & SD & Avg & SD & Avg & SD & Avg & SD & Avg & SD \\
\hline 23520 & 15 & 1 & $<0.1$ & 0.1 & $<0.7$ & 0.2 & $<0.04$ & 0.01 & 0.014 & 0.019 & $<0.07$ & 0.03 \\
\hline 23530 & 105 & 5 & $<0.1$ & 0.2 & $<0.7$ & 0.2 & $<0.04$ & 0.02 & 0.043 & 0.025 & $<0.07$ & 0.04 \\
\hline 23611 & 176 & 6 & $<0.1$ & 0.1 & $<0.7$ & 0.2 & $<0.04$ & 0.02 & 0.038 & 0.010 & $<0.07$ & 0.02 \\
\hline 23631 & 92 & 4 & $<0.1$ & 0.1 & 1.1 & 1.2 & $<0.04$ & 0.02 & 0.063 & 0.060 & 0.09 & 0.00 \\
\hline 23767 & 118 & 7 & 0.2 & 0.5 & 0.9 & 0.4 & $<0.04$ & 0.02 & 0.024 & 0.001 & $<0.07$ & 0.02 \\
\hline 23777 & 49 & 1 & $<0.1$ & 0.2 & $<0.7$ & 1.0 & $<0.04$ & 0.01 & $<0.008$ & 0.002 & $<0.07$ & 0.00 \\
\hline 24031 & 72 & 3 & $<0.1$ & 0.1 & $<0.7$ & 0.1 & $<0.04$ & 0.02 & 0.042 & 0.016 & $<0.07$ & 0.02 \\
\hline 24089 & 54 & 2 & 0.2 & 0.3 & $<0.7$ & 0.1 & $<0.04$ & 0.02 & 0.030 & 0.016 & $<0.07$ & 0.02 \\
\hline 24095 & 153 & 10 & 0.4 & 0.8 & 2.1 & 0.4 & $<0.04$ & 0.01 & 0.032 & 0.003 & $<0.07$ & 0.02 \\
\hline 24174 & 336 & 15 & 2.4 & 3.2 & 0.7 & 0.1 & $<0.04$ & 0.04 & 0.092 & 0.016 & $<0.07$ & 0.04 \\
\hline 24186 & 609 & 11 & $<0.1$ & 0.3 & 0.9 & 0.2 & $<0.04$ & 0.03 & 0.15 & 0.02 & $<0.07$ & 0.01 \\
\hline 24192 & 181 & 6 & 0.3 & 0.6 & 2.0 & 0.1 & $<0.04$ & 0.01 & 0.024 & 0.008 & $<0.07$ & 0.03 \\
\hline
\end{tabular}

\begin{tabular}{|c|c|c|c|c|c|c|c|c|c|c|c|c|}
\hline \multirow[t]{2}{*}{$\begin{array}{c}\text { Laboratory } \\
\text { ID }\end{array}$} & \multicolumn{2}{|c|}{$\begin{array}{c}\text { Cadmium } \\
\text { Cd } \\
\mu \mathrm{g} / \mathrm{L}\end{array}$} & \multicolumn{2}{|c|}{$\begin{array}{c}\text { Cerium } \\
\mathrm{Ce} \\
\mu \mathrm{g} / \mathrm{L}\end{array}$} & \multicolumn{2}{|c|}{$\begin{array}{c}\text { Cobalt } \\
\text { Co } \\
\mu \mathrm{g} / \mathrm{L}\end{array}$} & \multicolumn{2}{|c|}{$\begin{array}{c}\text { Chromium } \\
\mathrm{Cr} \\
\mu \mathrm{g} / \mathrm{L} \\
\end{array}$} & \multicolumn{2}{|c|}{$\begin{array}{c}\text { Cesium } \\
\text { Cs } \\
\mu \mathrm{g} / \mathrm{L}\end{array}$} & \multicolumn{2}{|c|}{$\begin{array}{c}\text { Copper } \\
\mathrm{Cu} \\
\mu \mathrm{g} / \mathrm{L}\end{array}$} \\
\hline & Avg & SD & Avg & SD & Avg & SD & Avg & SD & Avg & SD & Avg & SD \\
\hline 23520 & 0.05 & 0.01 & 0.026 & 0.002 & $<0.03$ & 0.01 & $<0.9$ & 0.1 & $<0.03$ & 0.04 & 0.3 & 0.1 \\
\hline 23530 & 0.03 & 0.01 & 0.084 & 0.007 & $<0.03$ & 0.00 & $<0.9$ & 1.1 & $<0.03$ & 0.01 & $<0.3$ & 0.1 \\
\hline 23611 & 0.12 & 0.01 & 0.059 & 0.006 & $<0.03$ & 0.00 & $<0.9$ & 0.6 & $<0.03$ & 0.02 & 0.7 & 0.0 \\
\hline 23621 & 0.02 & 0.00 & 0.019 & 0.003 & $<0.03$ & 0.00 & $<0.9$ & 0.9 & 0.05 & 0.03 & 0.5 & 0.2 \\
\hline 23631 & $<0.02$ & 0.01 & 0.042 & 0.004 & $<0.03$ & 0.01 & $<0.9$ & 0.3 & $<0.03$ & 0.01 & $<0.3$ & 0.3 \\
\hline 23767 & 0.05 & 0.02 & 0.033 & 0.001 & $<0.03$ & 0.00 & $<0.9$ & 0.8 & $<0.03$ & 0.02 & 1.1 & 0.6 \\
\hline 23777 & 0.02 & 0.01 & 0.013 & 0.001 & $<0.03$ & 0.01 & $<0.9$ & 1.3 & $<0.03$ & 0.04 & $<0.3$ & 0.1 \\
\hline 24031 & 0.02 & 0.01 & 0.051 & 0.001 & 0.08 & 0.01 & 2.9 & 0.6 & 0.57 & 0.02 & 1.5 & 0.2 \\
\hline 24053 & 0.04 & 0.01 & 0.055 & 0.006 & $<0.03$ & 0.01 & $<0.9$ & 0.2 & $<0.03$ & 0.03 & 0.4 & 0.3 \\
\hline 24063 & $<0.02$ & 0.00 & 0.034 & 0.005 & 0.03 & 0.01 & 1.6 & 0.5 & $<0.03$ & 0.03 & 0.4 & 0.4 \\
\hline 24083 & $<0.02$ & 0.01 & 0.23 & 0.01 & $<0.03$ & 0.01 & $<0.9$ & 1.8 & 0.04 & 0.01 & $<0.3$ & 0.1 \\
\hline 24089 & $<0.02$ & 0.01 & 0.047 & 0.008 & $<0.03$ & 0.01 & 1.1 & 1.3 & $<0.03$ & 0.02 & $<0.3$ & 0.1 \\
\hline 24095 & 0.02 & 0.00 & 0.11 & 0.09 & $<0.03$ & 0.00 & $<0.9$ & 1.5 & 1.3 & 0.0 & $<0.3$ & 0.0 \\
\hline 24174 & $<0.02$ & 0.02 & 0.058 & 0.007 & $<0.03$ & 0.03 & $<0.9$ & 1.2 & 0.13 & 0.03 & $<0.3$ & 0.3 \\
\hline 24186 & 0.02 & 0.00 & 0.094 & 0.017 & $<0.03$ & 0.01 & $<0.9$ & 1.7 & 0.06 & 0.01 & $<0.3$ & 0.1 \\
\hline 24192 & 0.05 & 0.01 & 0.071 & 0.028 & $<0.03$ & 0.01 & 0.9 & 1.6 & 0.28 & 0.01 & $<0.3$ & 0.0 \\
\hline
\end{tabular}


Table B2. Data for trace metals and major elements in digestion blanks-Continued.

[Averages (Avg) and standard deviations (SD) are for three or more replicate analyses of single digested subsample. Standard deviation for each analysis represents standard deviation of three or more ICP (inductively coupled plasma) analyses of single digestate. $\mu \mathrm{g} / \mathrm{L}, \mathrm{microgram}$ per liter; $\mathrm{mg} / \mathrm{L}$, milligram per liter; $<$, less than]

\begin{tabular}{|c|c|c|c|c|c|c|c|c|c|c|c|c|}
\hline \multirow[t]{2}{*}{$\begin{array}{c}\text { Laboratory } \\
\text { ID }\end{array}$} & \multicolumn{2}{|c|}{$\begin{array}{c}\text { Dysprosium } \\
\text { Dy } \\
\text { Hg/L }\end{array}$} & \multicolumn{2}{|c|}{$\begin{array}{c}\text { Erbium } \\
\text { Er } \\
\mu \mathrm{g} / \mathrm{L}\end{array}$} & \multicolumn{2}{|c|}{$\begin{array}{c}\text { Europium } \\
\text { Eu } \\
\mu \mathrm{g} / \mathrm{L} \\
\end{array}$} & \multicolumn{2}{|c|}{$\begin{array}{l}\text { Iron } \\
\mathrm{Fe} \\
\mu \mathrm{g} / \mathrm{L}\end{array}$} & \multicolumn{2}{|c|}{$\begin{array}{c}\text { Gallium } \\
\text { Ga } \\
\mu \mathrm{g} / \mathrm{L}\end{array}$} & \multicolumn{2}{|c|}{$\begin{array}{c}\text { Gadolinium } \\
\text { Gd } \\
\mu \mathrm{g} / \mathrm{L}\end{array}$} \\
\hline & Avg & SD & Avg & SD & Avg & SD & Avg & SD & Avg & SD & Avg & SD \\
\hline 23530 & 0.008 & 0.003 & 0.005 & 0.001 & 0.004 & 0.002 & 66 & 76 & $<0.007$ & 0.004 & 0.006 & 0.003 \\
\hline 23611 & 0.004 & 0.002 & 0.009 & 0.001 & $<0.002$ & 0.000 & $<50$ & 14 & $<0.007$ & 0.012 & 0.004 & 0.001 \\
\hline 23631 & 0.004 & 0.004 & $<0.004$ & 0.002 & $<0.002$ & 0.001 & $<50$ & 41 & 0.009 & 0.003 & $<0.004$ & 0.001 \\
\hline 23767 & 0.004 & 0.000 & $<0.004$ & 0.003 & $<0.002$ & 0.002 & 60 & 31 & $<0.007$ & 0.004 & $<0.004$ & 0.002 \\
\hline 23777 & $<0.003$ & 0.002 & $<0.004$ & 0.002 & $<0.002$ & 0.000 & 52 & 52 & 0.010 & 0.004 & $<0.004$ & 0.001 \\
\hline 24031 & 0.003 & 0.004 & $<0.004$ & 0.001 & 0.002 & 0.001 & 97 & 22 & $<0.007$ & 0.005 & $<0.004$ & 0.001 \\
\hline 24053 & 0.004 & 0.004 & $<0.004$ & 0.002 & 0.002 & 0.001 & $<50$ & 28 & 0.012 & 0.006 & $<0.004$ & 0.005 \\
\hline 24095 & 0.003 & 0.001 & $<0.004$ & 0.003 & $<0.002$ & 0.002 & $<50$ & 48 & $<0.007$ & 0.005 & $<0.004$ & 0.004 \\
\hline 24174 & 0.006 & 0.004 & $<0.004$ & 0.005 & 0.003 & 0.002 & 162 & 33 & $<0.007$ & 0.017 & 0.008 & 0.003 \\
\hline 24186 & 0.009 & 0.003 & 0.010 & 0.007 & 0.003 & 0.001 & 149 & 22 & $<0.007$ & 0.015 & 0.010 & 0.005 \\
\hline 24192 & 0.004 & 0.007 & 0.006 & 0.004 & $<0.002$ & 0.001 & $<50$ & 56 & $<0.007$ & 0.011 & 0.006 & 0.004 \\
\hline \multirow[t]{2}{*}{$\begin{array}{c}\text { Laboratory } \\
\text { ID }\end{array}$} & \multicolumn{2}{|c|}{$\begin{array}{c}\text { Holmium } \\
\text { Ho } \\
\mu g / L\end{array}$} & \multicolumn{2}{|c|}{$\begin{array}{c}\text { Potassium } \\
\text { K } \\
\mathrm{mg} / \mathrm{L} \\
\end{array}$} & \multicolumn{2}{|c|}{$\begin{array}{c}\text { Lanthanum } \\
\text { La } \\
\mu \mathrm{g} / \mathrm{L}\end{array}$} & \multicolumn{2}{|c|}{$\begin{array}{c}\text { Lithium } \\
\text { Li } \\
\mu g / L\end{array}$} & \multicolumn{2}{|c|}{$\begin{array}{c}\text { Lutetium } \\
\text { Lu } \\
\mu \mathrm{g} / \mathrm{L}\end{array}$} & \multicolumn{2}{|c|}{$\begin{array}{c}\text { Magnesium } \\
\text { Mg } \\
\mathrm{mg} / \mathrm{L}\end{array}$} \\
\hline & Avg & SD & Avg & SD & Avg & SD & Avg & SD & Avg & SD & Avg & SD \\
\hline 23520 & $<0.0010$ & 0.001 & $<0.09$ & 0.03 & 0.014 & 0.002 & $<0.1$ & 0.1 & $<0.0010$ & 0.000 & 0.005 & 0.004 \\
\hline 24053 & $<0.0010$ & 0.001 & $<0.09$ & 0.09 & 0.031 & 0.001 & $<0.1$ & 0.1 & $<0.0010$ & 0.000 & 0.025 & 0.004 \\
\hline 24063 & $<0.0010$ & 0.001 & $<0.09$ & 0.08 & 0.021 & 0.002 & $<0.1$ & 0.2 & $<0.0010$ & 0.000 & 0.023 & 0.020 \\
\hline 24083 & 0.003 & 0.001 & 0.10 & 0.07 & 0.12 & 0.01 & $<0.1$ & 0.0 & 0.001 & 0.000 & 0.053 & 0.034 \\
\hline 24089 & 0.001 & 0.000 & $<0.09$ & 0.04 & 0.020 & 0.006 & $<0.1$ & 0.1 & $<0.0010$ & 0.001 & 0.004 & 0.005 \\
\hline 24095 & $<0.0010$ & 0.001 & $<0.09$ & 0.08 & 0.060 & 0.064 & 0.2 & 0.0 & $<0.0010$ & 0.001 & 0.020 & 0.030 \\
\hline 24174 & 0.001 & 0.001 & $<0.09$ & 0.01 & 0.031 & 0.003 & 0.3 & 0.1 & $<0.0010$ & 0.001 & $<0.004$ & 0.000 \\
\hline 24186 & 0.003 & 0.002 & $<0.09$ & 0.01 & 0.043 & 0.011 & 0.5 & 0.1 & 0.002 & 0.001 & 0.013 & 0.015 \\
\hline 24192 & $<0.0010$ & 0.000 & $<0.09$ & 0.09 & 0.028 & 0.012 & $<0.1$ & 0.04 & $<0.0010$ & 0.001 & 0.010 & 0.002 \\
\hline
\end{tabular}


Table B2. Data for trace metals and major elements in digestion blanks-Continued.

[Averages (Avg) and standard deviations (SD) are for three or more replicate analyses of single digested subsample. Standard deviation for each analysis represents standard deviation of three or more ICP (inductively coupled plasma) analyses of single digestate. $\mu \mathrm{g} / \mathrm{L}$, microgram per liter; mg/L, milligram per liter; $<$, less than]

\begin{tabular}{|c|c|c|c|c|c|c|c|c|c|c|c|c|}
\hline \multirow[t]{2}{*}{$\begin{array}{c}\text { Laboratory } \\
\text { ID }\end{array}$} & \multicolumn{2}{|c|}{$\begin{array}{c}\text { Manganese } \\
\text { Mn } \\
\mu \mathrm{g} / \mathrm{L}\end{array}$} & \multicolumn{2}{|c|}{$\begin{array}{c}\text { Molybdenum } \\
\text { Mo } \\
\mu \mathrm{g} / \mathrm{L}\end{array}$} & \multicolumn{2}{|c|}{$\begin{array}{c}\text { Sodium } \\
\mathrm{Na} \\
\mathrm{mg} / \mathrm{L}\end{array}$} & \multicolumn{2}{|c|}{$\begin{array}{c}\text { Neodymium } \\
\text { Nd } \\
\mu g / L\end{array}$} & \multicolumn{2}{|c|}{$\begin{array}{c}\text { Nickel } \\
\mathrm{Ni} \\
\mu \mathrm{g} / \mathrm{L}\end{array}$} & \multicolumn{2}{|c|}{$\begin{array}{c}\text { Phosphorus } \\
P \\
\mu g / L\end{array}$} \\
\hline & Avg & SD & Avg & SD & Avg & SD & Avg & SD & Avg & SD & Avg & SD \\
\hline 23520 & $<0.6$ & 0.7 & $<0.3$ & 0.1 & $<0.02$ & 0.02 & 0.018 & 0.008 & $<0.1$ & 0.1 & $<50$ & 18 \\
\hline 23530 & $<0.6$ & 0.5 & $<0.3$ & 0.2 & 0.20 & 0.03 & 0.053 & 0.003 & 0.1 & 0.0 & $<50$ & 28 \\
\hline 23611 & 1.1 & 0.5 & $<0.3$ & 0.0 & 0.29 & 0.02 & 0.023 & 0.010 & 0.1 & 0.1 & $<50$ & 11 \\
\hline 23631 & $<0.6$ & 0.3 & $<0.3$ & 0.2 & 0.17 & 0.01 & 0.013 & 0.003 & $<0.1$ & 0.0 & $<50$ & 40 \\
\hline 23767 & 0.8 & 0.1 & 0.8 & 0.1 & 0.33 & 0.09 & $<0.009$ & 0.002 & 0.5 & 0.2 & $<50$ & 37 \\
\hline 23777 & $<0.6$ & 0.1 & $<0.3$ & 0.2 & 0.08 & 0.03 & $<0.009$ & 0.001 & 0.3 & 0.1 & $<50$ & 44 \\
\hline 24031 & 0.8 & 0.3 & 0.7 & 0.3 & 0.20 & 0.08 & 0.021 & 0.005 & 1.2 & 0.1 & $<50$ & 60 \\
\hline 24089 & $<0.6$ & 0.2 & 1.4 & 0.1 & 0.04 & 0.01 & 0.027 & 0.014 & 0.2 & 0.0 & $<50$ & 16 \\
\hline 24095 & $<0.6$ & 0.1 & $<0.3$ & 0.3 & 0.31 & 0.02 & 0.060 & 0.070 & 0.6 & 0.0 & $<50$ & 34 \\
\hline 24174 & $<0.6$ & 0.8 & 0.3 & 0.3 & 0.85 & 0.06 & 0.025 & 0.009 & 1.0 & 0.1 & $<50$ & 7 \\
\hline 24186 & $<0.6$ & 0.5 & $<0.3$ & 0.4 & 1.5 & 0.1 & 0.030 & 0.014 & 0.7 & 0.2 & $<50$ & 33 \\
\hline 24192 & 0.8 & 0.1 & $<0.3$ & 0.2 & 0.09 & 0.03 & 0.025 & 0.008 & 0.3 & 0.1 & $<50$ & 26 \\
\hline
\end{tabular}

\begin{tabular}{|c|c|c|c|c|c|c|c|c|c|c|c|c|}
\hline \multirow[t]{2}{*}{$\begin{array}{c}\text { Laboratory } \\
\text { ID }\end{array}$} & \multicolumn{2}{|c|}{$\begin{array}{c}\text { Lead } \\
\mathrm{Pb} \\
\mu \mathrm{g} / \mathrm{L}\end{array}$} & \multicolumn{2}{|c|}{$\begin{array}{c}\text { Praseodymium } \\
\mathrm{Pr} \\
\mu \mathrm{g} / \mathrm{L}\end{array}$} & \multicolumn{2}{|c|}{$\begin{array}{c}\text { Rubidium } \\
\text { Rb } \\
\text { Hg/L }\end{array}$} & \multicolumn{2}{|c|}{$\begin{array}{c}\text { Rhenium } \\
\text { Re } \\
\mu g / L\end{array}$} & \multicolumn{2}{|c|}{$\begin{array}{c}\text { Sulfur } \\
\text { S } \\
\mathrm{mg} / \mathrm{L}\end{array}$} & \multicolumn{2}{|c|}{$\begin{array}{c}\text { Antimony } \\
\mathrm{Sb} \\
\mu \mathrm{g} / \mathrm{L}\end{array}$} \\
\hline & Avg & SD & Avg & SD & Avg & SD & Avg & SD & Avg & SD & Avg & SD \\
\hline 23520 & $<0.1$ & 0.1 & 0.004 & 0.001 & $<0.06$ & 0.04 & $<0.002$ & 0.000 & $<0.2$ & 0.1 & 0.04 & 0.02 \\
\hline 23530 & 0.2 & 0.1 & 0.011 & 0.001 & $<0.06$ & 0.02 & $<0.002$ & 0.001 & $<0.2$ & 0.1 & 0.05 & 0.07 \\
\hline 23611 & 0.2 & 0.1 & 0.008 & 0.001 & $<0.06$ & 0.02 & $<0.002$ & 0.001 & $<0.2$ & 0.1 & 0.06 & 0.01 \\
\hline 23631 & $<0.1$ & 0.1 & 0.005 & 0.002 & $<0.06$ & 0.03 & $<0.002$ & 0.001 & $<0.2$ & 0.1 & 0.05 & 0.05 \\
\hline 23767 & 0.1 & 0.1 & 0.004 & 0.001 & 0.14 & 0.15 & $<0.002$ & 0.001 & $<0.2$ & 0.0 & 0.29 & 0.01 \\
\hline 23777 & $<0.1$ & 0.0 & $<0.002$ & 0.000 & $<0.06$ & 0.04 & $<0.002$ & 0.001 & $<0.2$ & 0.1 & 0.03 & 0.07 \\
\hline 24031 & 0.4 & 0.1 & 0.008 & 0.002 & 0.11 & 0.04 & $<0.002$ & 0.001 & $<0.2$ & 0.1 & 0.05 & 0.02 \\
\hline 24089 & 0.1 & 0.1 & 0.005 & 0.001 & $<0.06$ & 0.01 & $<0.002$ & 0.000 & $<0.2$ & 0.2 & 0.04 & 0.02 \\
\hline 24095 & 0.4 & 0.0 & 0.016 & 0.019 & 0.07 & 0.04 & $<0.002$ & 0.001 & $<0.2$ & 0.1 & 0.38 & 0.03 \\
\hline 24174 & 0.1 & 0.1 & 0.007 & 0.001 & 0.13 & 0.06 & $<0.002$ & 0.000 & $<0.2$ & 0.1 & 0.09 & 0.01 \\
\hline 24186 & 0.2 & 0.1 & 0.013 & 0.003 & 0.15 & 0.03 & $<0.002$ & 0.002 & $<0.2$ & 0.0 & 0.15 & 0.05 \\
\hline 24192 & $<0.1$ & 0.1 & 0.006 & 0.002 & $<0.06$ & 0.0 & $<0.002$ & 0.001 & $<0.2$ & 0.1 & 0.02 & 0.01 \\
\hline
\end{tabular}


Table B2. Data for trace metals and major elements in digestion blanks-Continued.

[Averages (Avg) and standard deviations (SD) are for three or more replicate analyses of single digested subsample. Standard deviation for each analysis represents standard deviation of three or more ICP (inductively coupled plasma) analyses of single digestate. $\mu \mathrm{g} / \mathrm{L}, \mathrm{microgram}$ per liter; $\mathrm{mg} / \mathrm{L}$, milligram per liter; $<$, less than]

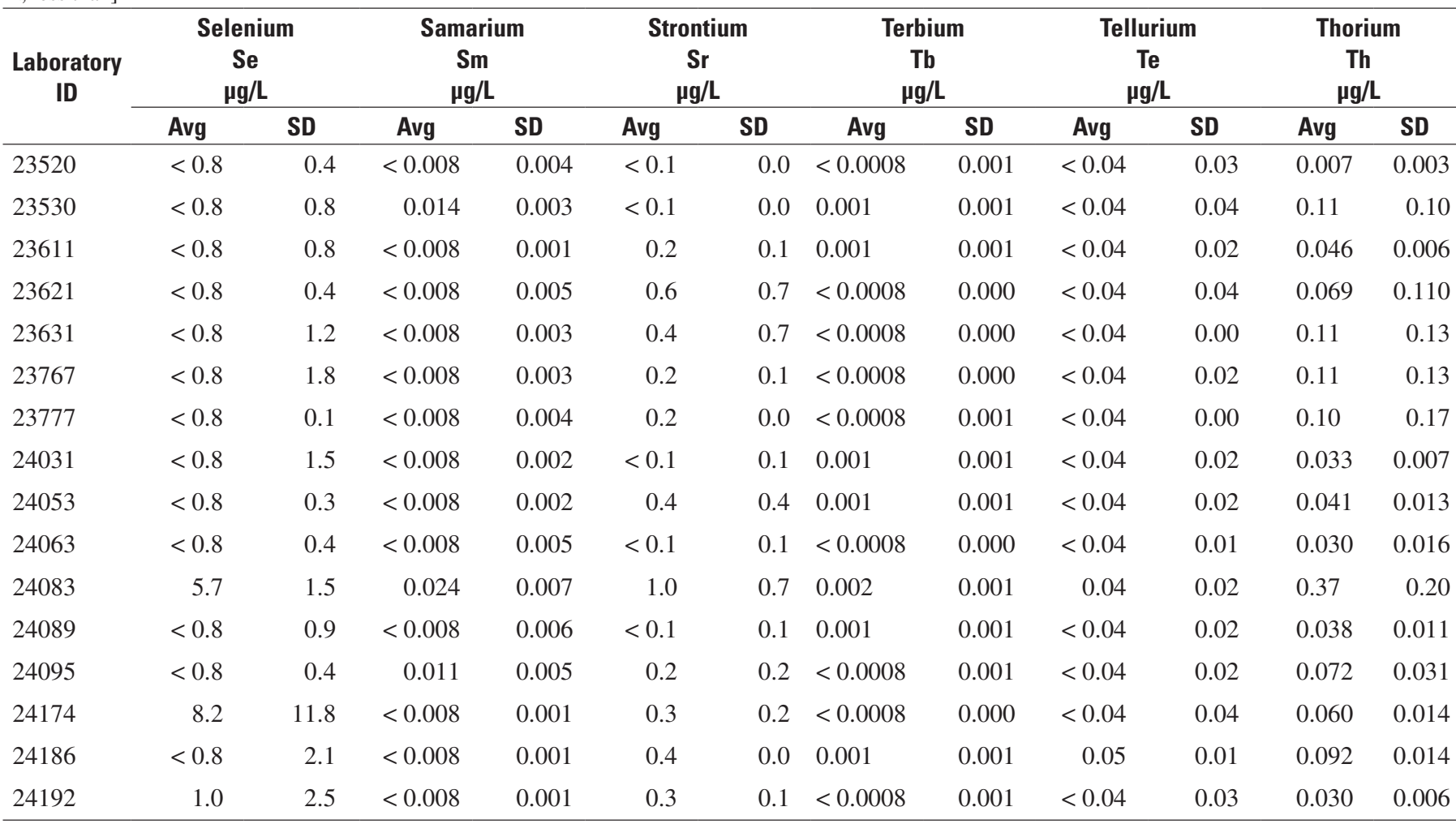

\begin{tabular}{|c|c|c|c|c|c|c|c|c|c|c|}
\hline \multirow[t]{2}{*}{$\begin{array}{c}\text { Laboratory } \\
\text { ID }\end{array}$} & \multicolumn{2}{|c|}{$\begin{array}{c}\text { Titanium } \\
\mathrm{Ti} \\
\boldsymbol{\mu g} / \mathrm{L} \\
\end{array}$} & \multicolumn{2}{|c|}{$\begin{array}{c}\text { Thallium } \\
\mathrm{TI} \\
\mu \mathrm{g} / \mathrm{L} \\
\end{array}$} & \multicolumn{2}{|c|}{$\begin{array}{l}\text { Thulium } \\
\text { Tm } \\
\mu \mathrm{g} / \mathrm{L}\end{array}$} & \multicolumn{2}{|c|}{$\begin{array}{c}\text { Uranium } \\
\mathbf{U} \\
\mu \mathrm{g} / \mathrm{L}\end{array}$} & \multicolumn{2}{|c|}{$\begin{array}{c}\text { Vanadium } \\
\mathbf{V} \\
\mu \mathrm{g} / \mathrm{L}\end{array}$} \\
\hline & Avg & SD & Avg & SD & Avg & SD & Avg & SD & Avg & SD \\
\hline 23520 & $<6$ & 3 & $<0.06$ & 0.05 & $<0.001$ & 0.000 & $<0.007$ & 0.002 & $<2$ & 1 \\
\hline 23530 & $<6$ & 7 & $<0.06$ & 0.09 & $<0.001$ & 0.000 & 0.023 & 0.019 & $<2$ & 0 \\
\hline 23611 & $<6$ & 6 & $<0.06$ & 0.04 & $<0.001$ & 0.000 & 0.019 & 0.002 & $<2$ & 1 \\
\hline 23621 & $<6$ & 6 & $<0.06$ & 0.05 & $<0.001$ & 0.001 & $<0.007$ & 0.001 & $<2$ & 1 \\
\hline 23631 & 15 & 10 & $<0.06$ & 0.03 & $<0.001$ & 0.000 & $<0.007$ & 0.000 & $<2$ & 1 \\
\hline 23767 & 8 & 2 & $<0.06$ & 0.02 & $<0.001$ & 0.000 & 0.035 & 0.055 & $<2$ & 1 \\
\hline 23777 & $<6$ & 5 & $<0.06$ & 0.05 & $<0.001$ & 0.001 & $<0.007$ & 0.001 & $<2$ & 1 \\
\hline 24031 & 7 & 7 & $<0.06$ & 0.03 & $<0.001$ & 0.001 & $<0.007$ & 0.002 & $<2$ & 2 \\
\hline 24053 & 10 & 6 & $<0.06$ & 0.01 & $<0.001$ & 0.000 & $<0.007$ & 0.003 & $<2$ & 2 \\
\hline 24063 & $<6$ & 8 & $<0.06$ & 0.03 & $<0.001$ & 0.001 & 0.014 & 0.002 & $<2$ & 2 \\
\hline 24083 & $<6$ & 8 & $<0.06$ & 0.07 & 0.001 & 0.001 & 0.060 & 0.075 & 2 & 0 \\
\hline 24089 & 7 & 7 & 0.07 & 0.08 & $<0.001$ & 0.000 & $<0.007$ & 0.01 & $<2$ & 1 \\
\hline 24095 & 8 & 8 & $<0.06$ & 0.04 & $<0.001$ & 0.001 & $<0.007$ & 0.00 & $<2$ & 1 \\
\hline 24174 & $<6$ & 2 & $<0.06$ & 0.00 & $<0.001$ & 0.001 & 0.009 & 0.001 & $<2$ & 1 \\
\hline 24186 & 15 & 4 & $<0.06$ & 0.03 & 0.002 & 0.001 & 0.015 & 0.002 & $<2$ & 0 \\
\hline 24192 & 6 & 7 & $<0.06$ & 0.05 & $<0.001$ & 0.001 & $<0.007$ & 0.004 & $<2$ & 0 \\
\hline
\end{tabular}


Table B2. Data for trace metals and major elements in digestion blanks-Continued.

[Averages (Avg) and standard deviations (SD) are for three or more replicate analyses of single digested subsample. Standard deviation for each analysis represents standard deviation of three or more ICP (inductively coupled plasma) analyses of single digestate. $\mu \mathrm{g} / \mathrm{L}$, microgram per liter; mg/L, milligram per liter; $<$, less than]

\begin{tabular}{|c|c|c|c|c|c|c|c|c|c|c|}
\hline $\begin{array}{c}\text { Laboratory } \\
\text { ID }\end{array}$ & \multicolumn{2}{|c|}{$\begin{array}{c}\text { Tungsten } \\
\text { W } \\
\mu \mathrm{g} / \mathrm{L}\end{array}$} & \multicolumn{2}{|c|}{$\begin{array}{c}\text { Yttrium } \\
Y \\
\mu g / L\end{array}$} & \multicolumn{2}{|c|}{$\begin{array}{c}\text { Ytterbium } \\
\mathrm{Yb} \\
\mu \mathrm{g} / \mathrm{L}\end{array}$} & \multicolumn{2}{|c|}{$\begin{array}{c}\text { Zinc } \\
\text { Zn } \\
\mu \mathrm{g} / \mathrm{L}\end{array}$} & \multicolumn{2}{|c|}{$\begin{array}{c}\text { Zirconium } \\
\mathrm{Zr} \\
\boldsymbol{\mu g} / \mathrm{L}\end{array}$} \\
\hline 23520 & $<0.02$ & 0.01 & 0.011 & 0.002 & $<0.002$ & 0.001 & 4 & 3 & 0.11 & 0.02 \\
\hline 23530 & $<0.02$ & 0.01 & 0.044 & 0.007 & 0.004 & 0.001 & $<2$ & 1 & 2.4 & 0.2 \\
\hline 23631 & $<0.02$ & 0.00 & 0.013 & 0.003 & 0.003 & 0.001 & 7 & 2 & 2.2 & 0.2 \\
\hline 23767 & $<0.02$ & 0.01 & 0.018 & 0.003 & 0.004 & 0.002 & 15 & 4 & 2.4 & 0.1 \\
\hline 23777 & $<0.02$ & 0.00 & 0.007 & 0.003 & $<0.002$ & 0.001 & 5 & 1 & 0.73 & 0.29 \\
\hline 24031 & 4.9 & 0.1 & 0.017 & 0.004 & 0.004 & 0.002 & 13 & 4 & 2.1 & 0.1 \\
\hline 24083 & 0.03 & 0.02 & 0.090 & 0.000 & 0.011 & 0.001 & 13 & 3 & 2.7 & 0.3 \\
\hline 24089 & $<0.02$ & 0.01 & 0.021 & 0.006 & $<0.002$ & 0.001 & 5 & 0 & 1.0 & 0.0 \\
\hline 24095 & $<0.02$ & 0.01 & 0.026 & 0.008 & 0.005 & 0.002 & 13 & 6 & 2.8 & 0.1 \\
\hline 24174 & 0.03 & 0.01 & 0.039 & 0.009 & 0.007 & 0.005 & 4 & 1 & 8.8 & 0.4 \\
\hline 24186 & $<0.02$ & 0.00 & 0.079 & 0.009 & 0.018 & 0.001 & 6 & 1 & 16 & 1 \\
\hline 24192 & $<0.02$ & 0.01 & 0.020 & 0.013 & $<0.002$ & 0.002 & 4 & 1 & 1.7 & 0.4 \\
\hline
\end{tabular}


Table B3. Recovery data for trace-metal spikes in sediment samples from Englebright Lake, California, 2002.

[Numbers are percent recovery, computed as measured value divided by expected value; - , not determined]

\begin{tabular}{rrrrcrcr}
\hline Date & $\begin{array}{c}\text { Arsenic } \\
\mathbf{A s}\end{array}$ & $\begin{array}{c}\text { Cadmium } \\
\mathbf{C d}\end{array}$ & $\begin{array}{c}\text { Calcium } \\
\mathbf{C a}\end{array}$ & $\begin{array}{c}\text { Copper } \\
\mathbf{C u}\end{array}$ & $\begin{array}{c}\text { Lead } \\
\mathbf{P b}\end{array}$ & $\begin{array}{c}\text { Magnesium } \\
\mathbf{M g}\end{array}$ & $\begin{array}{c}\text { Zinc } \\
\mathbf{Z n}\end{array}$ \\
\hline $7 / 13 / 2004$ & 107 & 103 & - & 100 & 99 & - & 106 \\
$7 / 16 / 2004$ & 97 & 94 & 109 & 93 & 89 & 107 & 97 \\
$7 / 16 / 2004$ & 121 & 106 & - & 102 & 99 & - & 106 \\
$7 / 30 / 2004$ & 101 & 100 & 110 & 98 & 97 & 111 & 102 \\
$8 / 5 / 2004$ & 100 & 97 & 108 & 89 & 94 & 104 & 97 \\
$8 / 6 / 2004$ & 105 & 98 & 113 & 89 & 93 & 113 & 97 \\
\hline
\end{tabular}

Table B4. Data for trace metals and major elements in replicate sediment subsamples from Englebright Lake, California, 2002. See Excel table B4 at App_B_TableB4.xls

Table B5. Data for trace metals and major elements from the $Y$ series of subsamples from the May-June 2002 deep cores from Englebright Lake, California.

See Excel table B5 at App_B_TableB5.xls 


\section{Appendix C. Mineralogical and Grain-Size Distribution Data for Heavy Mineral Concentrates}

Table C1. Particle-size distribution of bulk composite core samples prior to preparation of heavy mineral concentrates, Englebright Lake, California, 2002.

[mm, millimeter; g, gram; m, meter; >, greater than; <, less than]

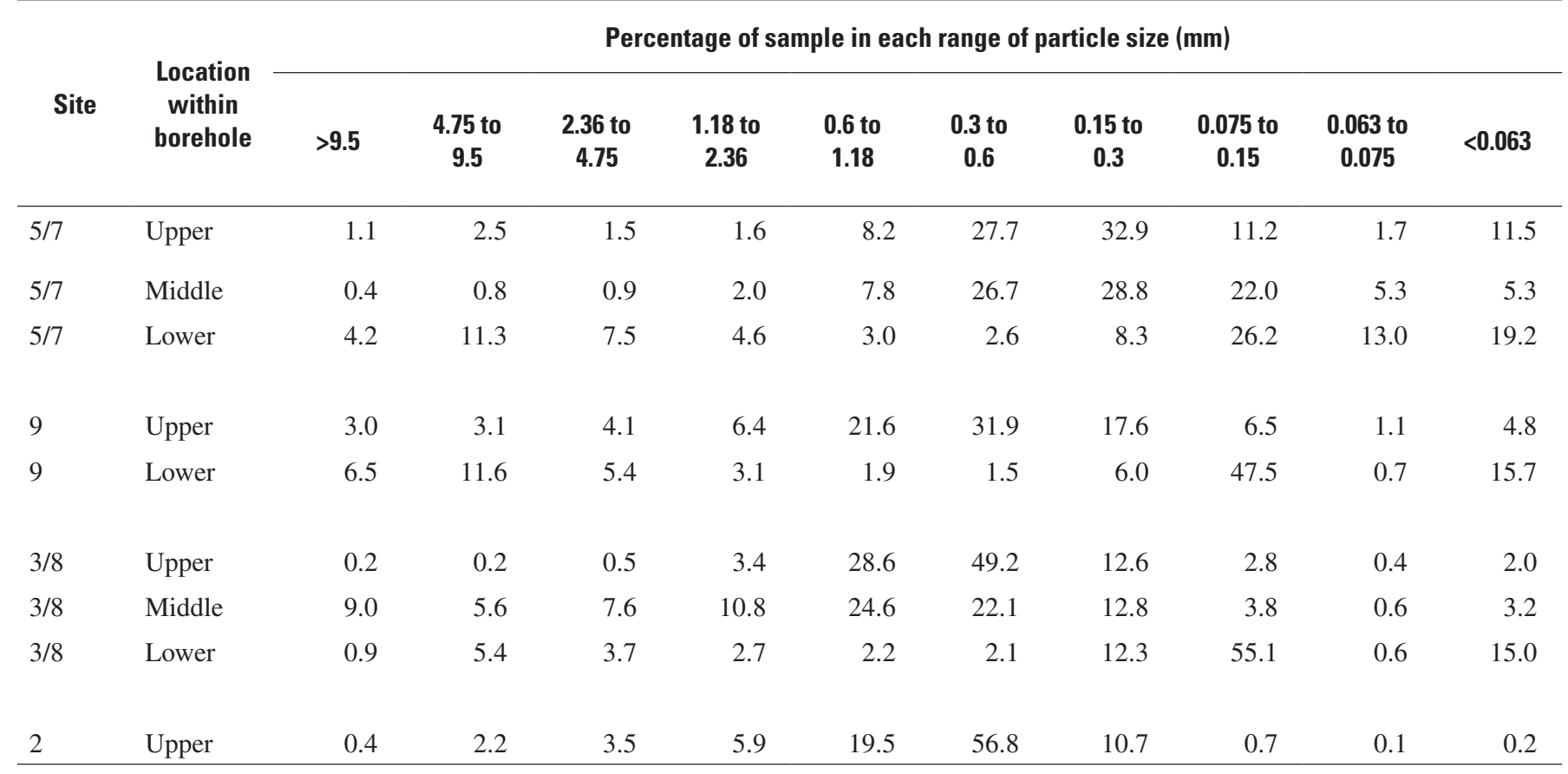

\begin{tabular}{|c|c|c|c|c|c|}
\hline Site & $\begin{array}{c}\text { Total } \\
\text { weight of } \\
\text { composite } \\
\text { (g) }\end{array}$ & $\begin{array}{l}\text { Amount } \\
\text { processed } \\
\text { (fraction of } \\
\text { total) }\end{array}$ & $\begin{array}{l}\text { Total length } \\
\text { of cores } \\
\text { composited } \\
\text { (m) }\end{array}$ & $\begin{array}{l}\text { Depth range below } \\
\text { top of } \\
\text { sediment } \\
(\mathrm{m})\end{array}$ & Core sections \\
\hline $5 / 7$ & 21,932 & $1 / 4$ & 8.83 & 0 to 10.05 & $5 \mathrm{~A}-1 \mathrm{H}-1$ through $5 \mathrm{~A}-5 \mathrm{H}-1$ \\
\hline $5 / 7$ & 22,152 & $1 / 4$ & 10.59 & 11.14 to 23.91 & 7B-1H-2 through 7B-8H-1 \\
\hline $5 / 7$ & 9,876 & $1 / 4$ & 6.2 & 24.15 to 30.82 & $7 \mathrm{~B}-9 \mathrm{H}-1$ through 7B-12H-1 \\
\hline 9 & 23,708 & $1 / 4$ & 11.5 & 0 to 16.08 & 9B-1H-1 through 9B-7H-2 \\
\hline 9 & 12,280 & $1 / 4$ & 6.51 & 16.78 to 23.51 & $9 \mathrm{~B}-8 \mathrm{H}-1$ through $9 \mathrm{~B}-10 \mathrm{H}-1$ \\
\hline $3 / 8$ & 9,680 & $1 / 4$ & 3.93 & 0 to 4.92 & $3 \mathrm{D}-1 \mathrm{H}-1$ through $3 \mathrm{D}-4 \mathrm{E}-1$ \\
\hline $3 / 8$ & 16,992 & $1 / 4$ & 6.56 & 6.16 to 14.08 & $8 \mathrm{~A}-4 \mathrm{H}-1$ through $8 \mathrm{~A}-10 \mathrm{H}-1$ \\
\hline $3 / 8$ & 10,140 & $1 / 4$ & 7.2 & 14.53 to 22.51 & $8 \mathrm{~A}-11 \mathrm{H}-1$ through $8 \mathrm{~A}-14 \mathrm{H}-1$ \\
\hline 2 & 2,576 & $1 / 2$ & 1.46 & 0 to 1.46 & 2B-1H-1 \\
\hline
\end{tabular}


Table C2. Particle-size distribution and gold tenor of heavy mineral concentrates, Englebright Lake, California, 2002.

[g, gram; mm, millimeter; mg, milligram; mg/m³ , milligram per cubic meter; <, less than]

\begin{tabular}{|c|c|c|c|c|c|c|c|c|c|c|}
\hline \multirow{2}{*}{ Site } & \multirow{2}{*}{$\begin{array}{l}\text { Location } \\
\text { within } \\
\text { borehole }\end{array}$} & \multirow{2}{*}{$\begin{array}{c}\text { Heavy } \\
\text { mineral } \\
\text { concentrate, } \\
\text { total weight } \\
\text { (g) }\end{array}$} & \multicolumn{5}{|c|}{ Percentage of sample in each range of particle size $(\mathrm{mm})$} & \multirow{2}{*}{$\begin{array}{l}\text { Number of } \\
\text { gold grains } \\
\text { observed }\end{array}$} & \multirow{2}{*}{$\begin{array}{l}\text { Estimated } \\
\text { gold } \\
\text { weight } \\
\text { (mg) }\end{array}$} & \multirow{2}{*}{$\begin{array}{c}\text { Gold } \\
\text { tenor } \\
\left(\mathrm{mg} / \mathrm{m}^{3}\right)\end{array}$} \\
\hline & & & $\begin{array}{c}1.0 \text { to } \\
2.0\end{array}$ & $\begin{array}{c}0.5 \text { to } \\
1.0\end{array}$ & $\begin{array}{c}0.25 \text { to } \\
0.50\end{array}$ & $\begin{array}{c}0.063 \text { to } \\
0.25\end{array}$ & $<0.063$ & & & \\
\hline $5 / 7$ & Upper & 55.2 & 0.0 & 0.2 & 0.9 & 96.2 & 2.4 & 25 & 22.2 & 680 \\
\hline $5 / 7$ & Middle & 73.8 & 0.0 & 0.1 & 0.3 & 97.3 & 1.9 & 15 & 8.3 & 270 \\
\hline 9 & Upper & 107.3 & 0.1 & 0.1 & 6.8 & 91.9 & 0.9 & 8 & 2.2 & 92 \\
\hline 9 & Lower & 2.3 & 0.0 & 0.0 & 4.3 & 91.3 & 4.3 & 15 & 2.1 & 58 \\
\hline $3 / 8$ & Lower & 2.3 & 0.0 & 0.0 & 4.3 & 91.3 & 4.3 & 10 & 1.7 & 84 \\
\hline \multirow[t]{2}{*}{2} & Upper & 49.3 & 1.0 & 0.6 & 54.8 & 43.6 & 0 & 15 & 4.3 & 840 \\
\hline & & & & & & & & \multicolumn{2}{|r|}{ median } & 92 \\
\hline
\end{tabular}


Table C3. Mineralogical data from magnetic separation and optical microscopy for heavy mineral concentrates, Englebright Lake, California, 2002.

[Observations: —, not observed; $\mathrm{x}$, trace; $\mathrm{xx}$, abundant; xxx, very abundant; C, coarse; F, fine; VF, very fine; rst, rust stained; UF, ultra fine. mg, milligram; mm, millimeter; g, gram. In last column, light minerals include zircon and feldspar; dark include ilmenite, chromite, hornblende, and diopside]

\begin{tabular}{|c|c|c|c|c|c|c|c|c|c|}
\hline Site & $\begin{array}{c}\text { Location } \\
\text { within } \\
\text { borehole }\end{array}$ & $\begin{array}{c}\text { Gold } \\
\text { description }\end{array}$ & $\begin{array}{l}\text { Amalgam } \\
\text { (gold- } \\
\text { mercury) }\end{array}$ & $\begin{array}{c}\text { Iron } \\
\text { ferricrete } \\
\text { nodules }\end{array}$ & Pyrite & Magnetite & $\begin{array}{l}\text { Misc- } \\
\text { ellaneous }\end{array}$ & $\begin{array}{c}\text { Total } \\
\text { heavy } \\
\text { minerals } \\
\text { (g) }\end{array}$ & $\begin{array}{c}\text { Strongly } \\
\text { magnetic } \\
\text { (magnetite) } \\
\text { (g) }\end{array}$ \\
\hline $5 / 7$ & Upper & C-F-VF & $\mathrm{xxx}$ & $\mathrm{xxx}$ & $\mathrm{xx}$ & $\mathrm{xx}$ & - & 55.2 & 31.4 \\
\hline $5 / 7$ & Middle & C-F-VF, rst & $\mathrm{x}$ & - & - & $\mathrm{xx}$ & - & 73.8 & 45.4 \\
\hline $5 / 7$ & Lower & C-F-VF, rst & - & - & - & $\mathrm{xx}$ & - & 3.8 & 1.6 \\
\hline 9 & Upper & $\mathrm{F}-\mathrm{VF}$ & - & - & - & $\mathrm{xx}$ & - & 107.3 & 39.8 \\
\hline 9 & Lower & $\mathrm{C}-\mathrm{VF}$ & - & - & - & $\mathrm{xx}$ & - & 2.3 & 0.8 \\
\hline $3 / 8$ & Upper & F-VF, rst & $\mathrm{x}$ & $\mathrm{x}$ & - & $\mathrm{xx}$ & - & 49.8 & 24.7 \\
\hline 2 & Upper & $\mathrm{C}-\mathrm{VF}$, rst & - & $\mathrm{x}$ & - & $\mathrm{xx}$ & - & 49.3 & 4 \\
\hline
\end{tabular}

\begin{tabular}{|c|c|c|c|c|c|c|}
\hline \multirow[t]{2}{*}{ Site } & \multirow[t]{2}{*}{$\begin{array}{c}\text { Weakly } \\
\text { magnetic } \\
\text { (ferromagnesian } \\
\text { minerals) } \\
\text { (g) }\end{array}$} & \multirow[t]{2}{*}{$\begin{array}{c}\text { Non-magnetic } \\
\text { (light/dark } \\
\text { minerals) } \\
\text { (g) }\end{array}$} & \multirow[t]{2}{*}{$\begin{array}{c}\text { Total } \\
\text { magnetic } \\
\text { fraction } \\
\text { (weight } \\
\text { percent) }\end{array}$} & \multirow[t]{2}{*}{$\begin{array}{l}\text { Total non- } \\
\text { magnetic } \\
\text { fraction } \\
\text { (weight } \\
\text { percent) }\end{array}$} & \multicolumn{2}{|c|}{$\begin{array}{c}\text { Nonmagnetic } \\
\text { fraction: } \\
\text { Relative } \\
\text { percent of } \\
\text { light/dark } \\
\text { minerals }\end{array}$} \\
\hline & & & & & Light & Dark \\
\hline $5 / 7$ & 4.2 & 19.6 & 65 & 35 & 20 & 80 \\
\hline $5 / 7$ & 8.5 & 20 & 73 & 27 & 15 & 85 \\
\hline $5 / 7$ & 0.6 & 1.6 & 58 & 42 & 60 & 40 \\
\hline 9 & 3.8 & 63.7 & 41 & 59 & 60 & 40 \\
\hline 9 & 0 & 1.5 & 35 & 65 & 50 & 50 \\
\hline $3 / 8$ & 2.8 & 22.3 & 55 & 45 & 80 & 20 \\
\hline $3 / 8$ & 6.1 & 46.9 & 37 & 63 & 90 & 10 \\
\hline $3 / 8$ & 0 & 1 & 57 & 43 & 60 & 40 \\
\hline 2 & 1.1 & 44.2 & 10 & 90 & 95 & 5 \\
\hline
\end{tabular}




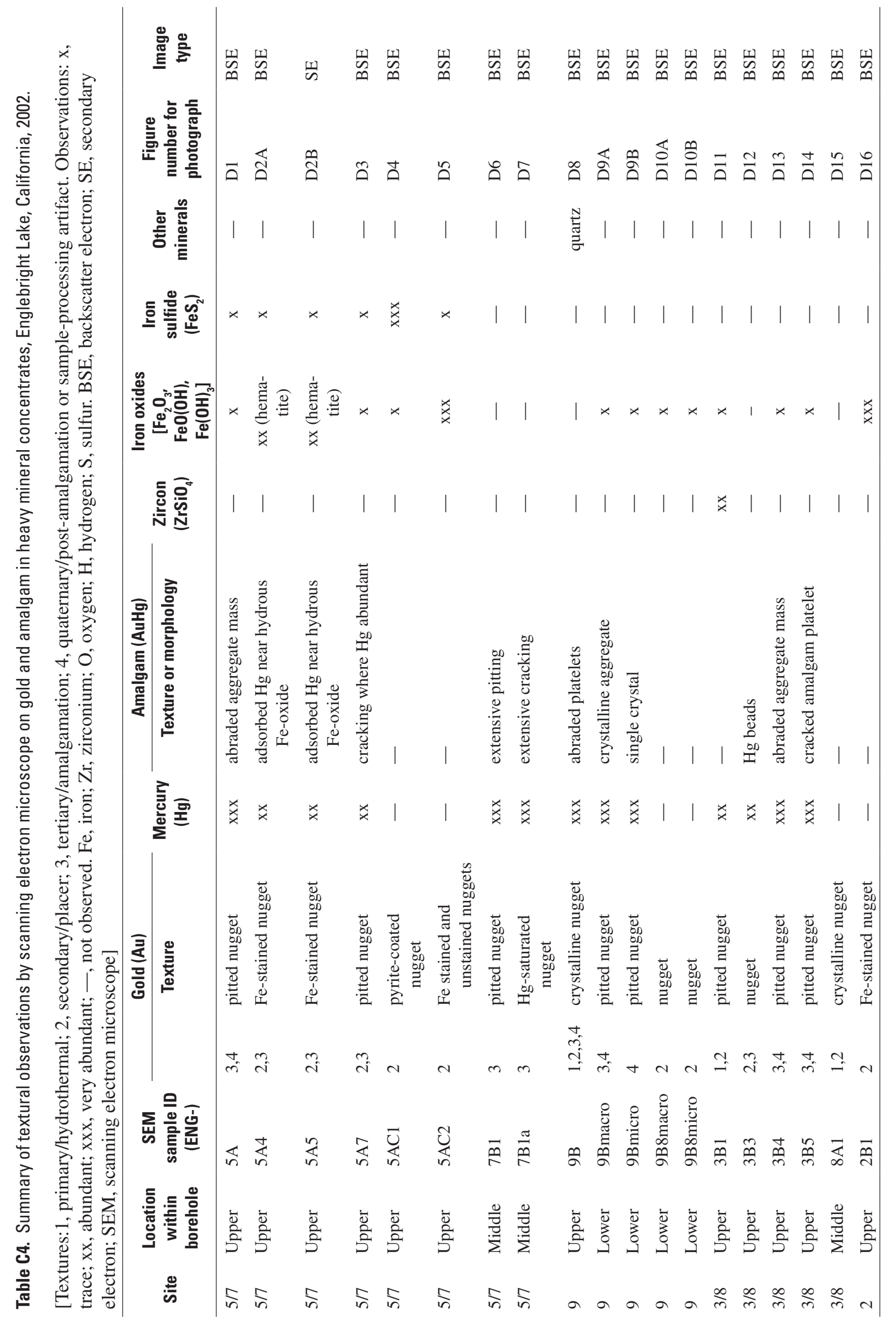




\section{Appendix D. Scanning Electron Microscope Photomicrographs Showing Gold and Amalgam} Textures from the Heavy Mineral Concentrates from Englebright Lake, California 2002

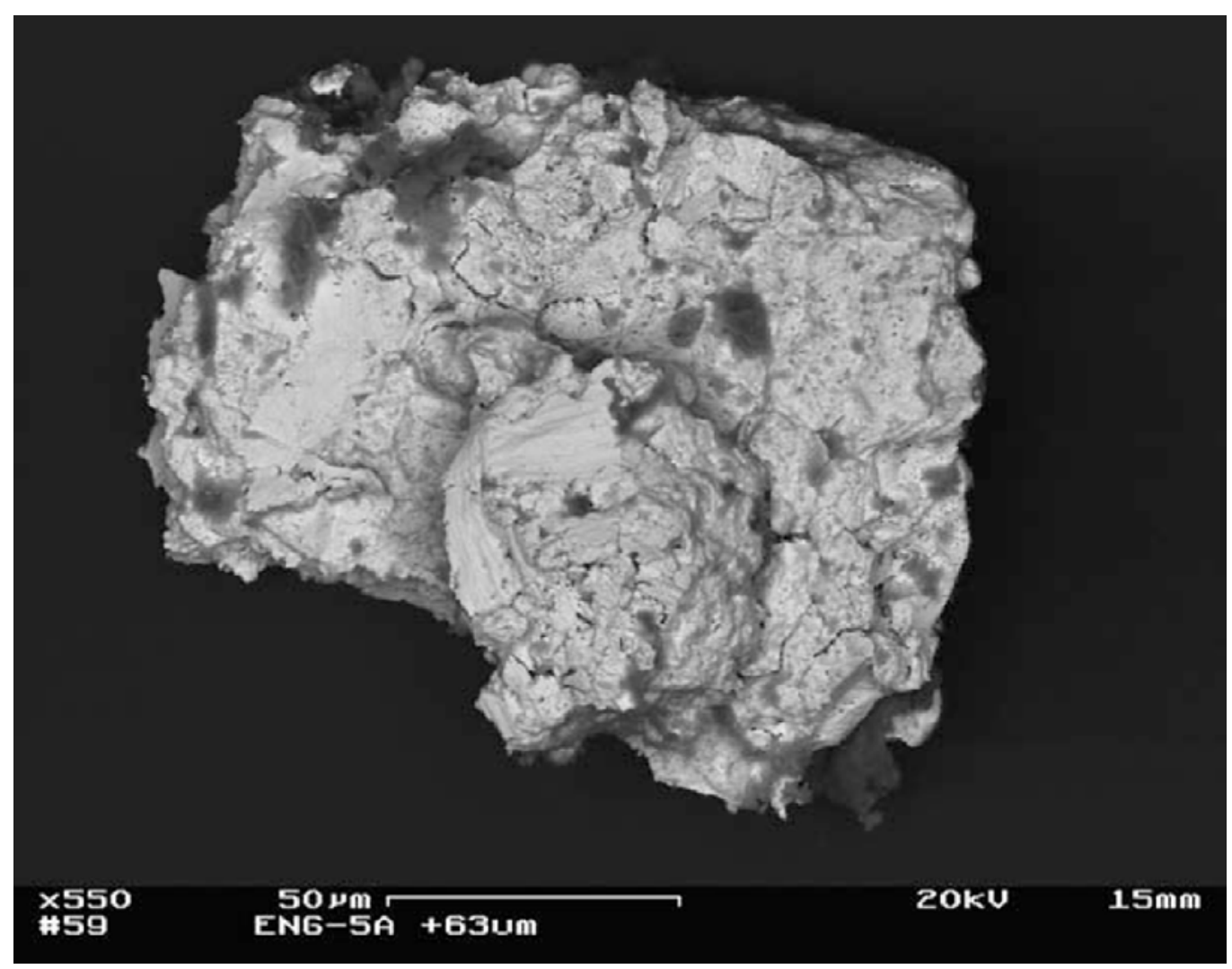

Figure D1. Amalgam grain showing abrasion from processing (sample 5A). 

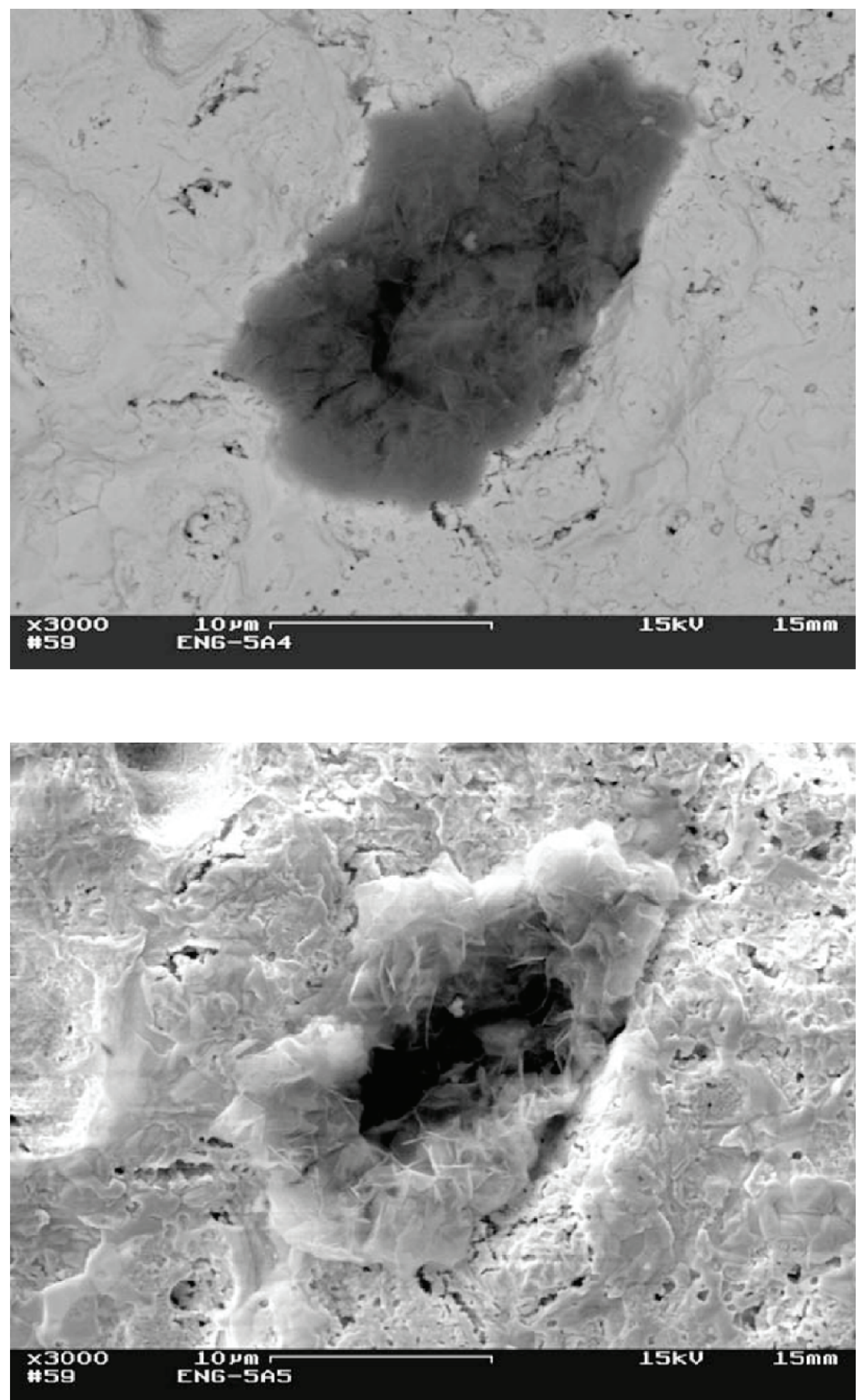

Figure D2. Two scanned electron microscope images of pseudo-hexagonal hematite platelets surrounded by mercury-rich halo, $(A)$ Backscatter, $(B)$ Secondary electron. 


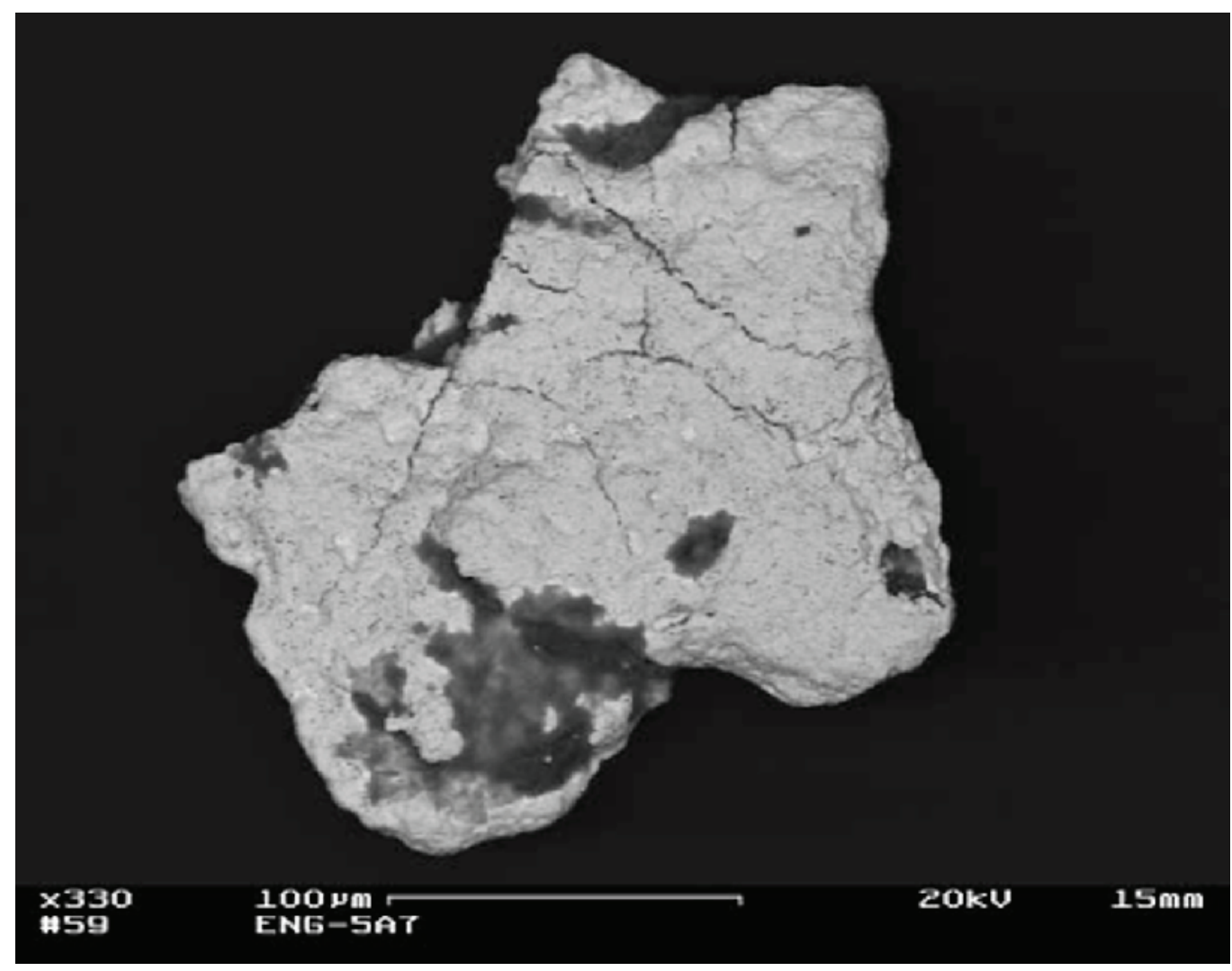

Figure D3. Gold grain with iron oxide (sample 5A7).

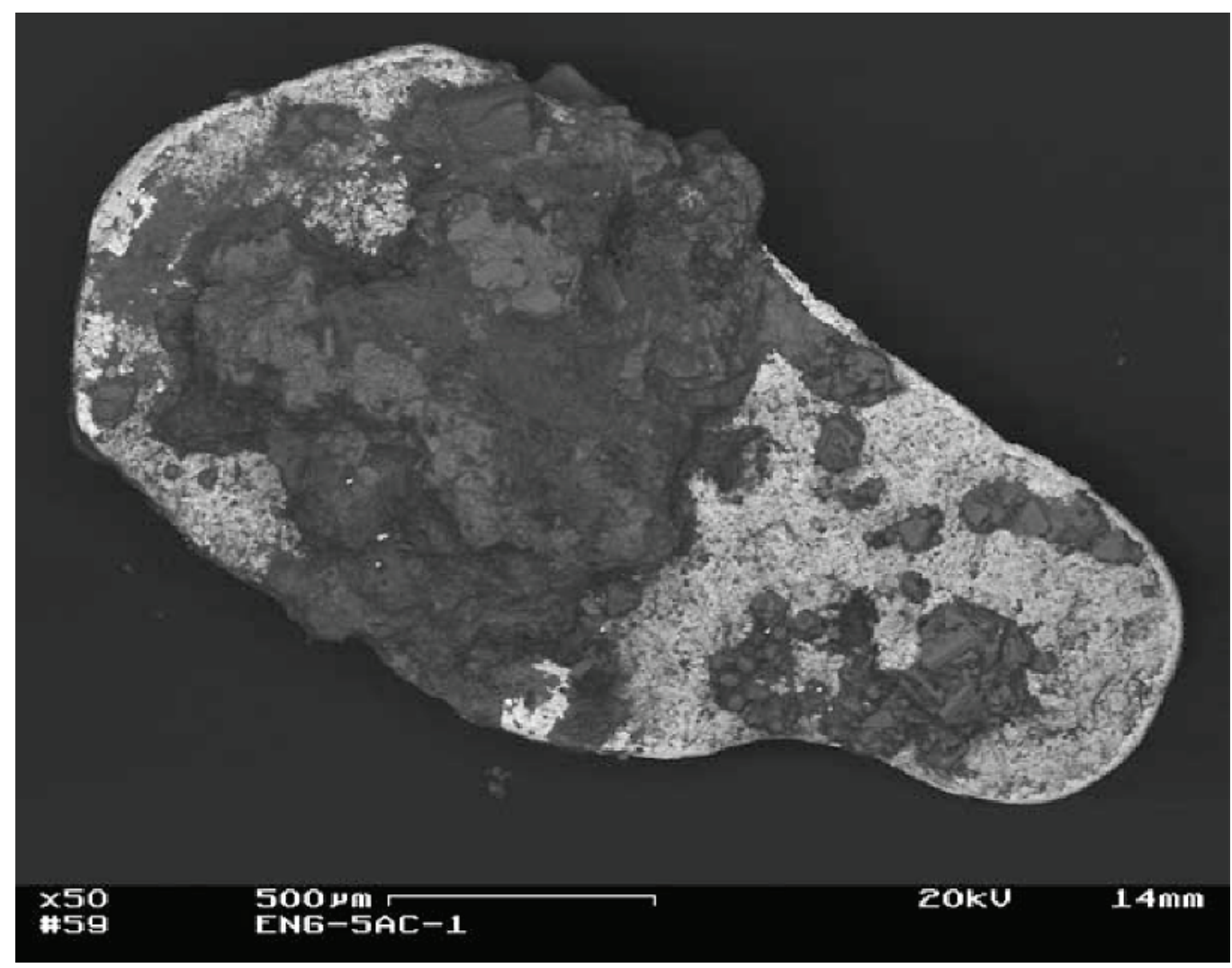

Figure D4. Gold grain with abundant diagenetic pyrite crystals (sample 5AC1). 


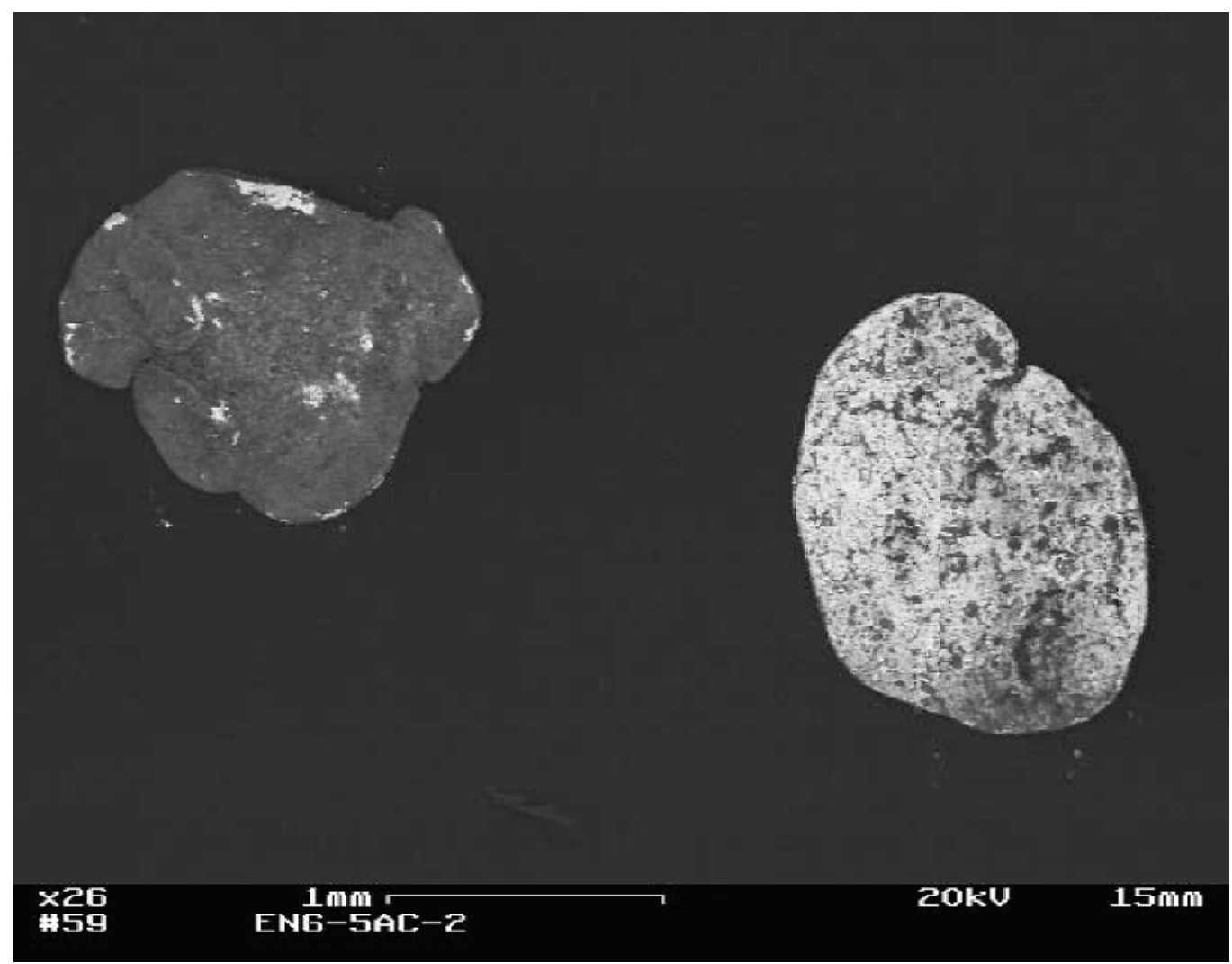

Figure D5. Iron-oxide coated gold nugget (on left) and clean gold nugget (on right) (sample 5AC2).

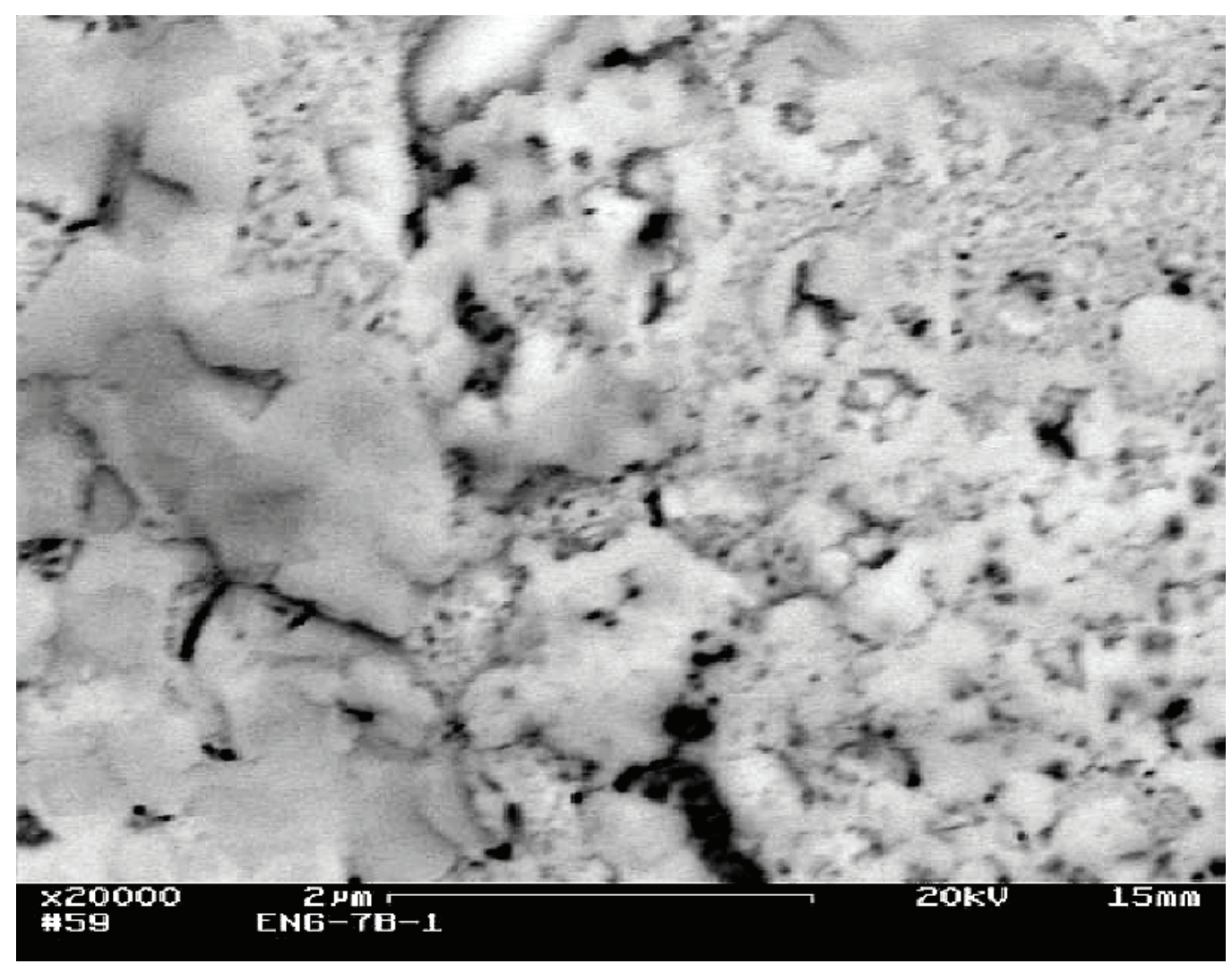

Figure D6. High magnification of pitted surface of gold nugget (sample 7B1). 


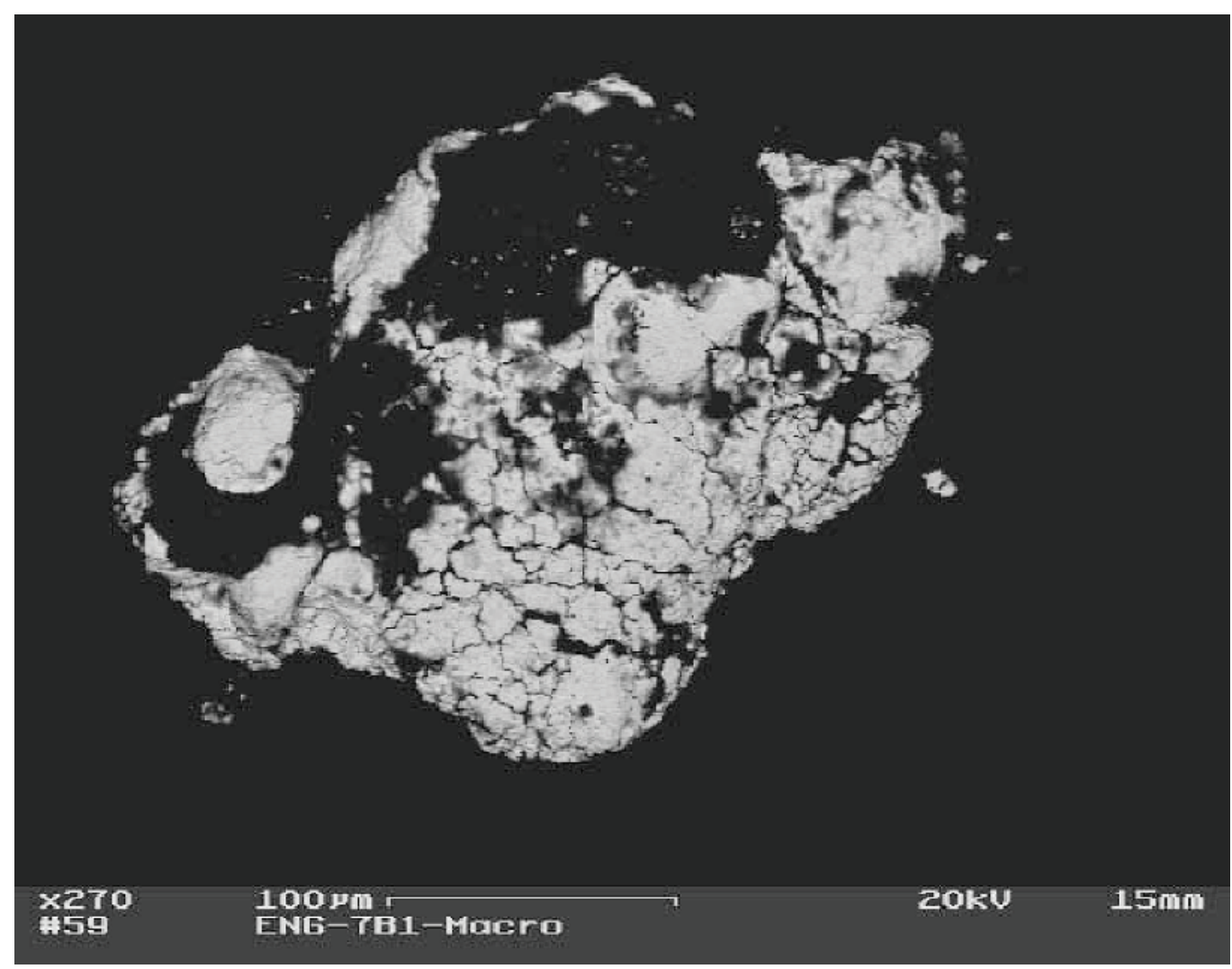

Figure D7. Extensive cracking of amalgam in mercury-saturated gold nugget (sample 7B1).

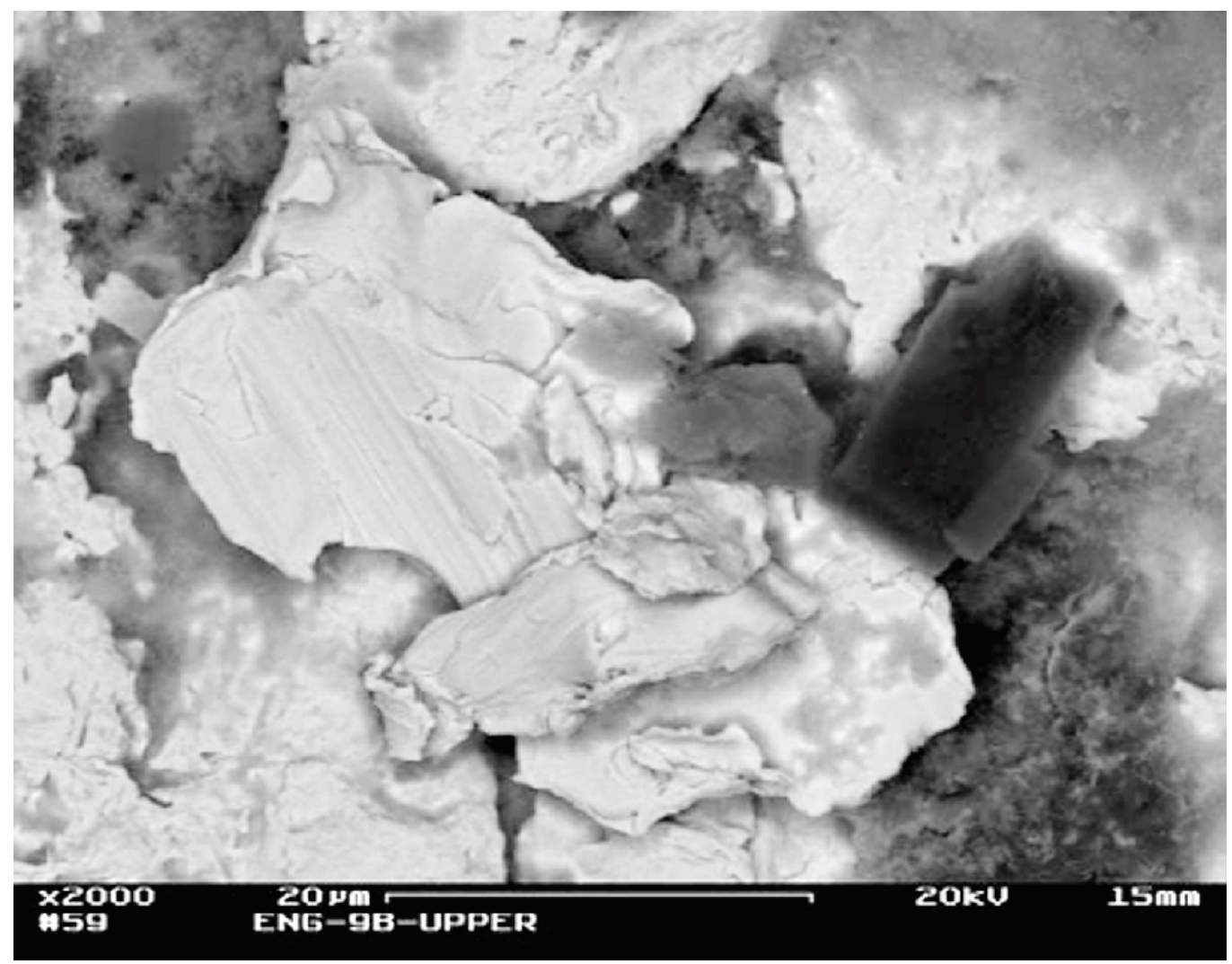

Figure D8. Close-up view of nugget showing abrasion of amalgam in cavity with euhedral quartz crystal (sample 9B). 

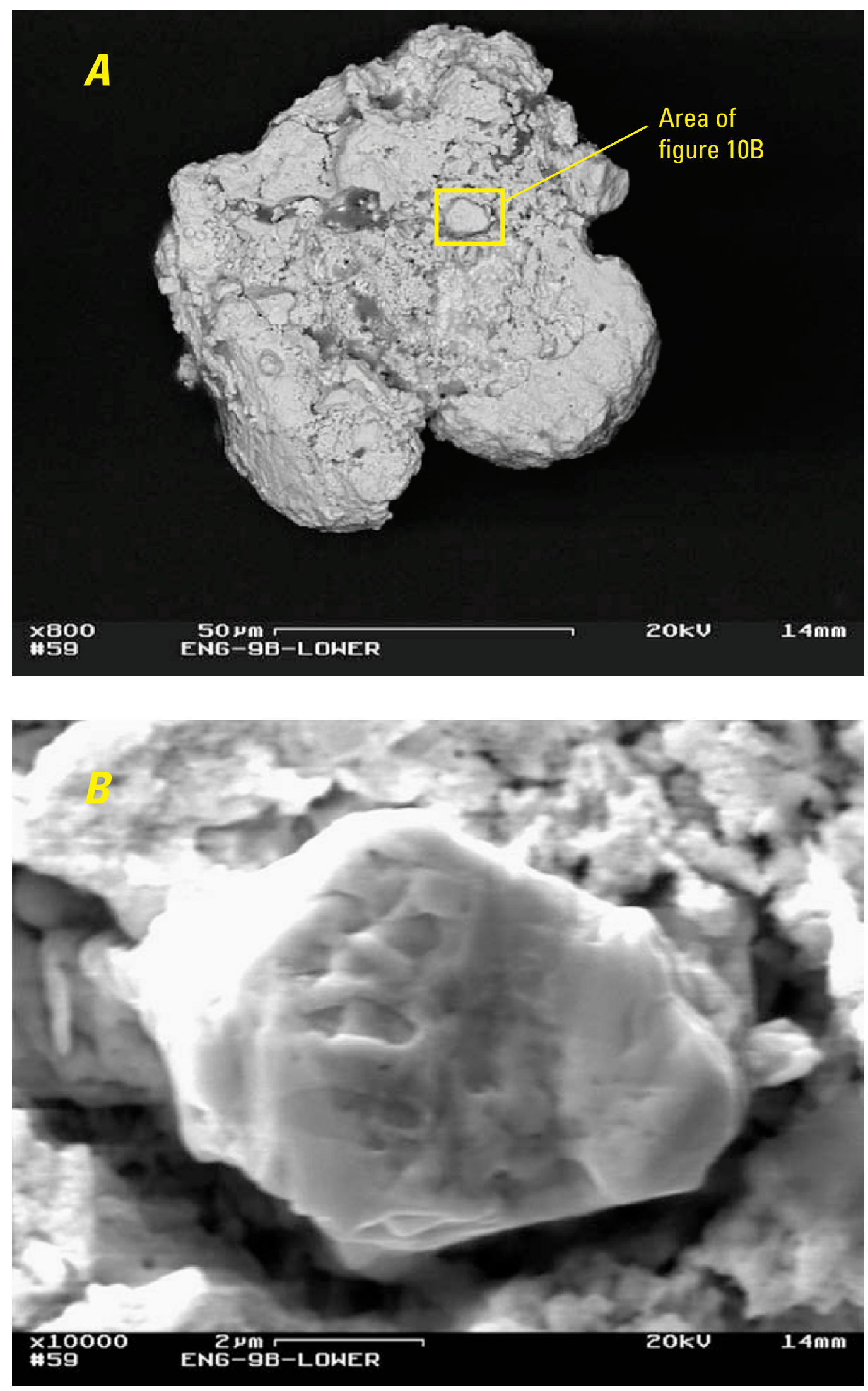

Figure D9. Amalgam grains (sample 9B) (A) Aggregate containing amalgam crystal in upper right, and $(B)$ Close-up view of the amalgam crystal, dimensions $6 \times 8$ micrometers. 

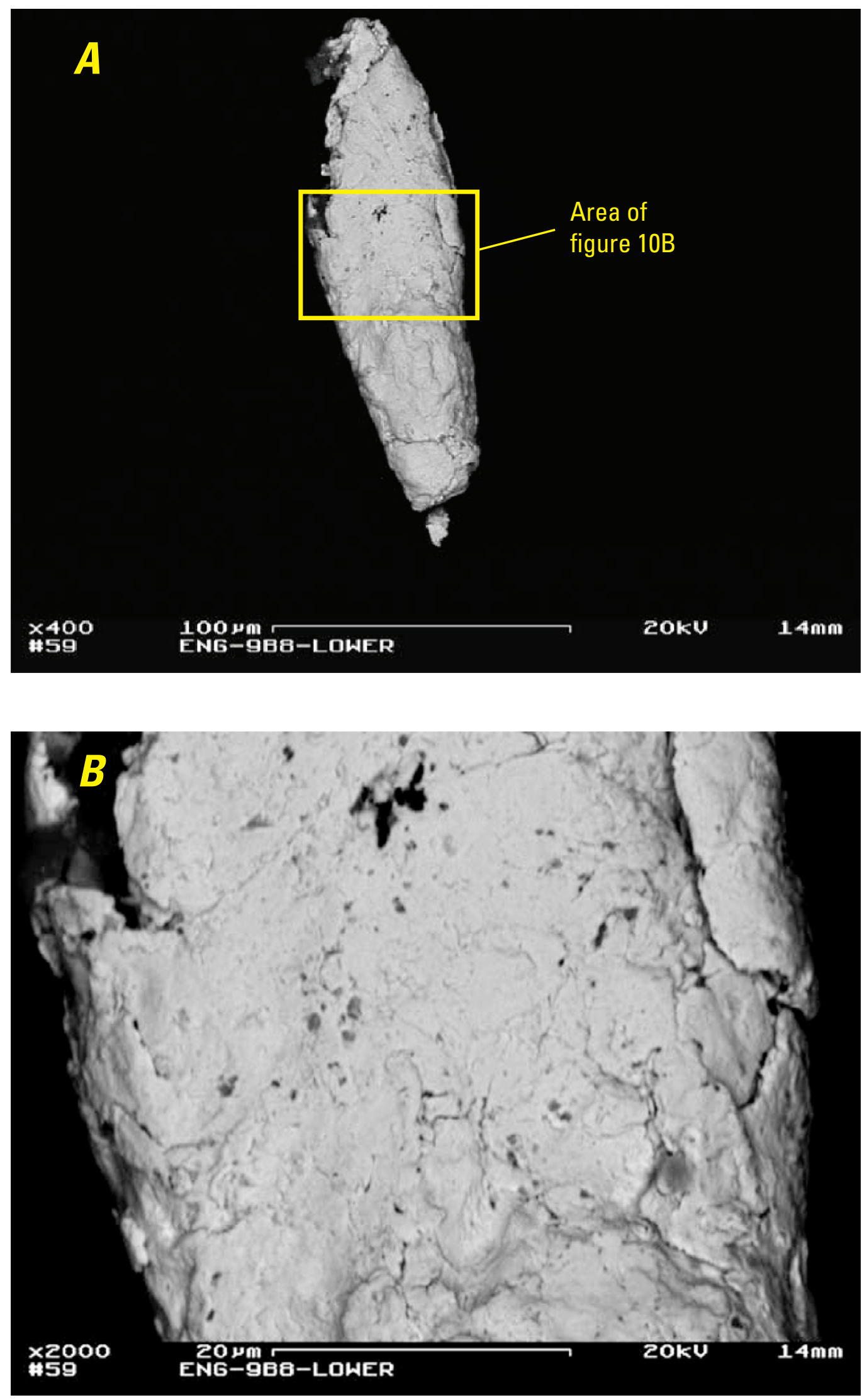

Figure D10. Placer gold grain of high purity, no visible mercury (sample 9B8) $(A)$ View of entire grain, $(B)$ Close-up view showing smooth texture of gold. 


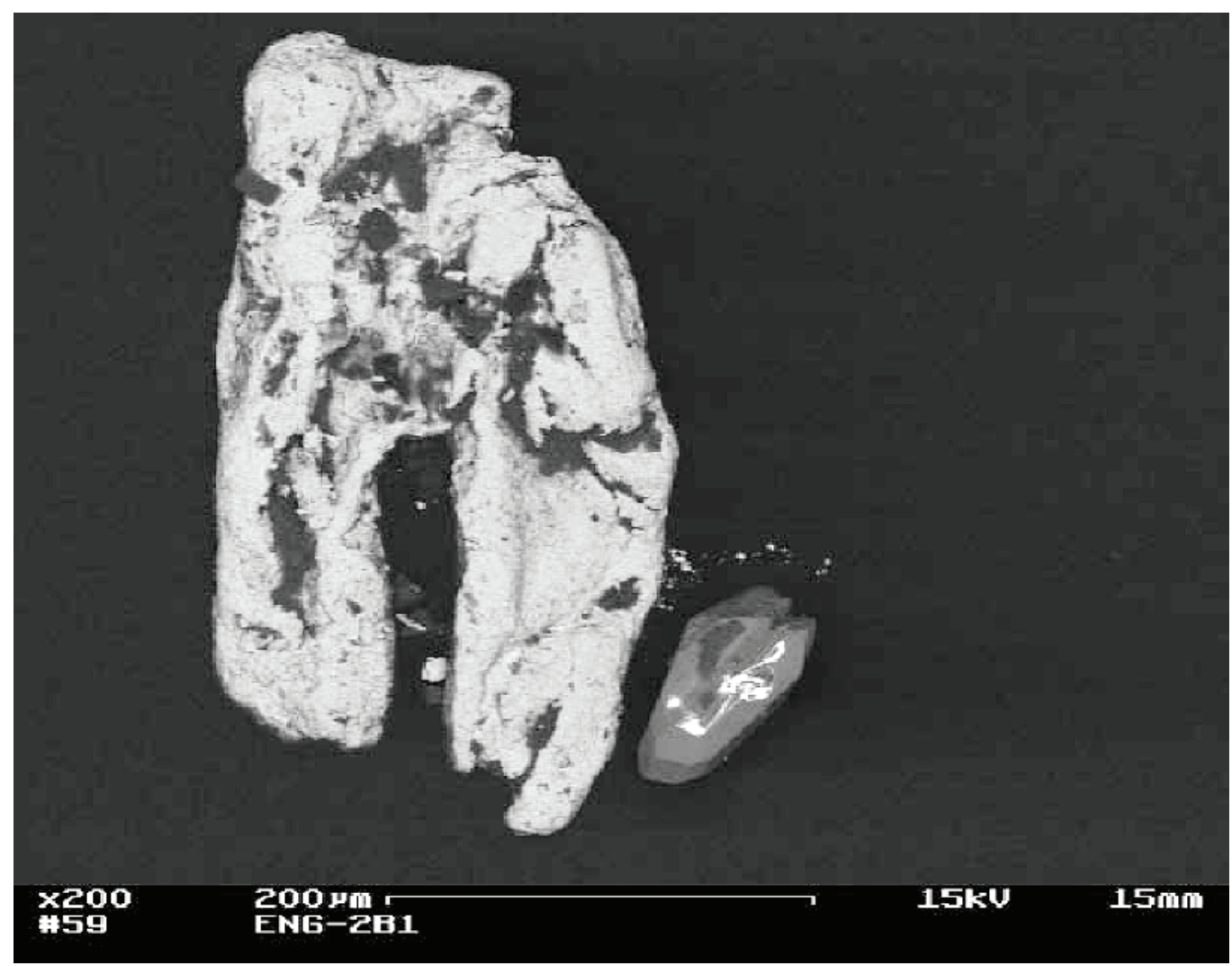

Figure D11. Large, pitted gold grain with 100-micrometer, euhedral zircon crystal (sample 3B1).

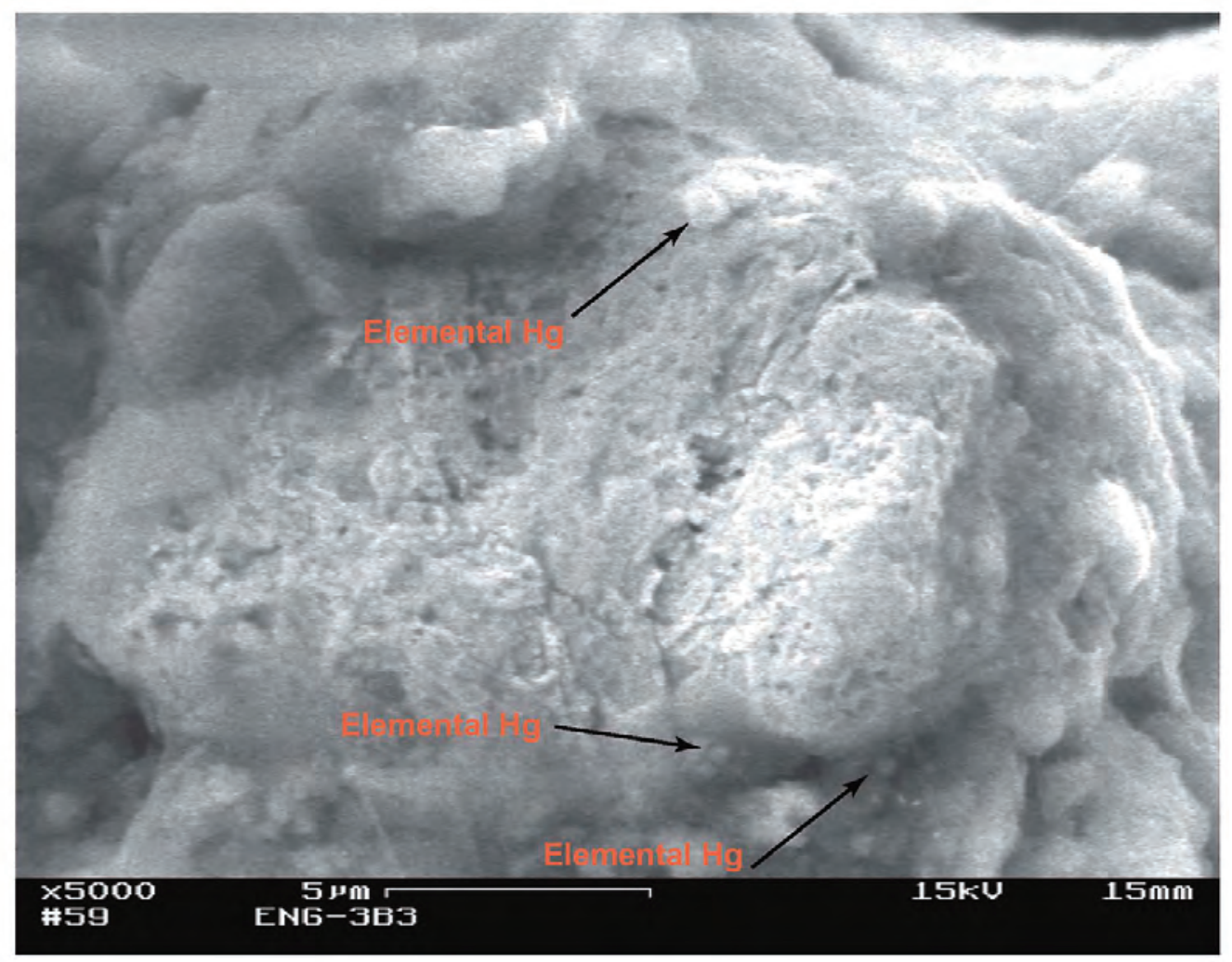

Figure D12. Grain of gold containing small beads of elemental mercury (sample 3B3). 


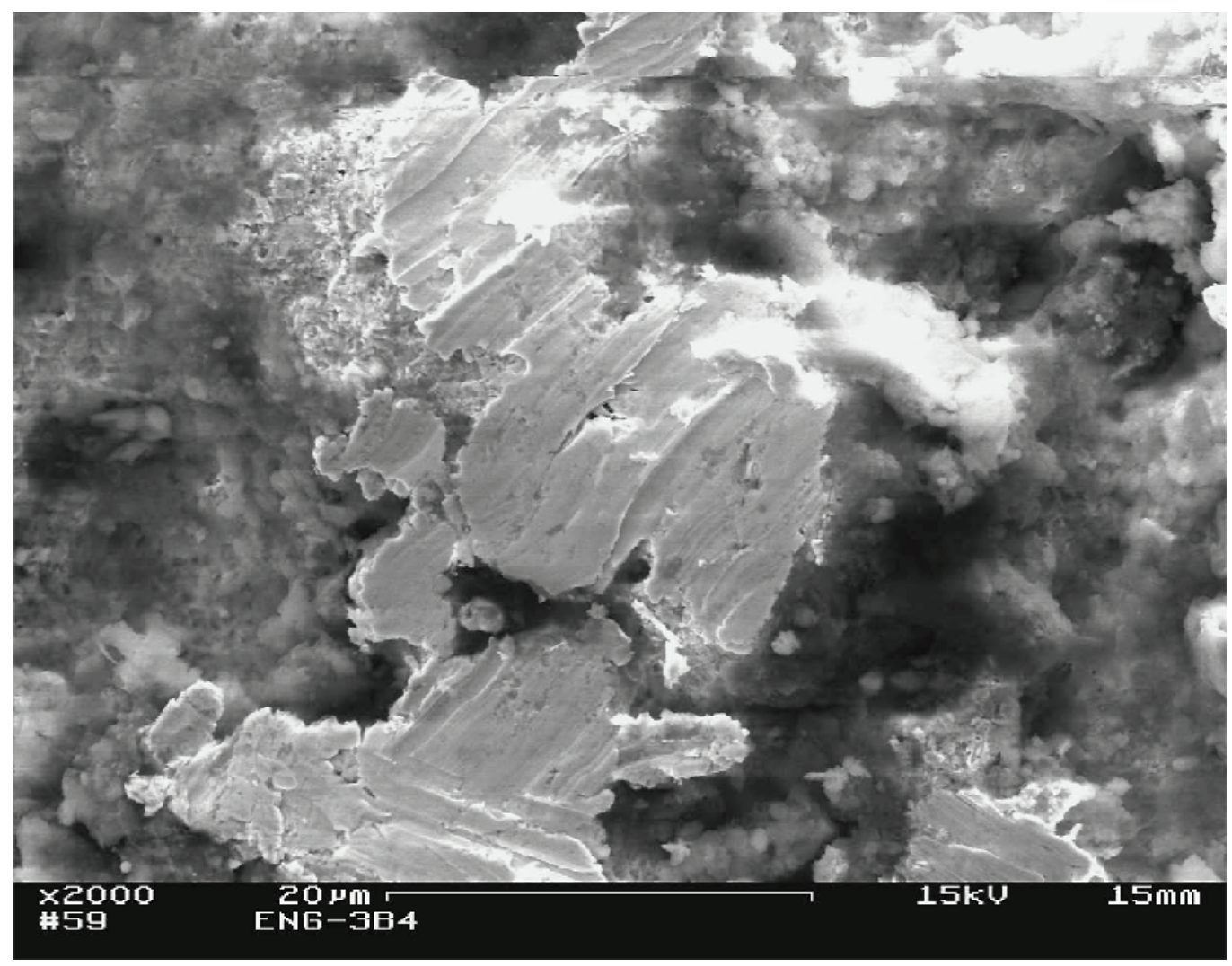

Figure D13. Grain of amalgam showing smearing from processing (sample 3B4).

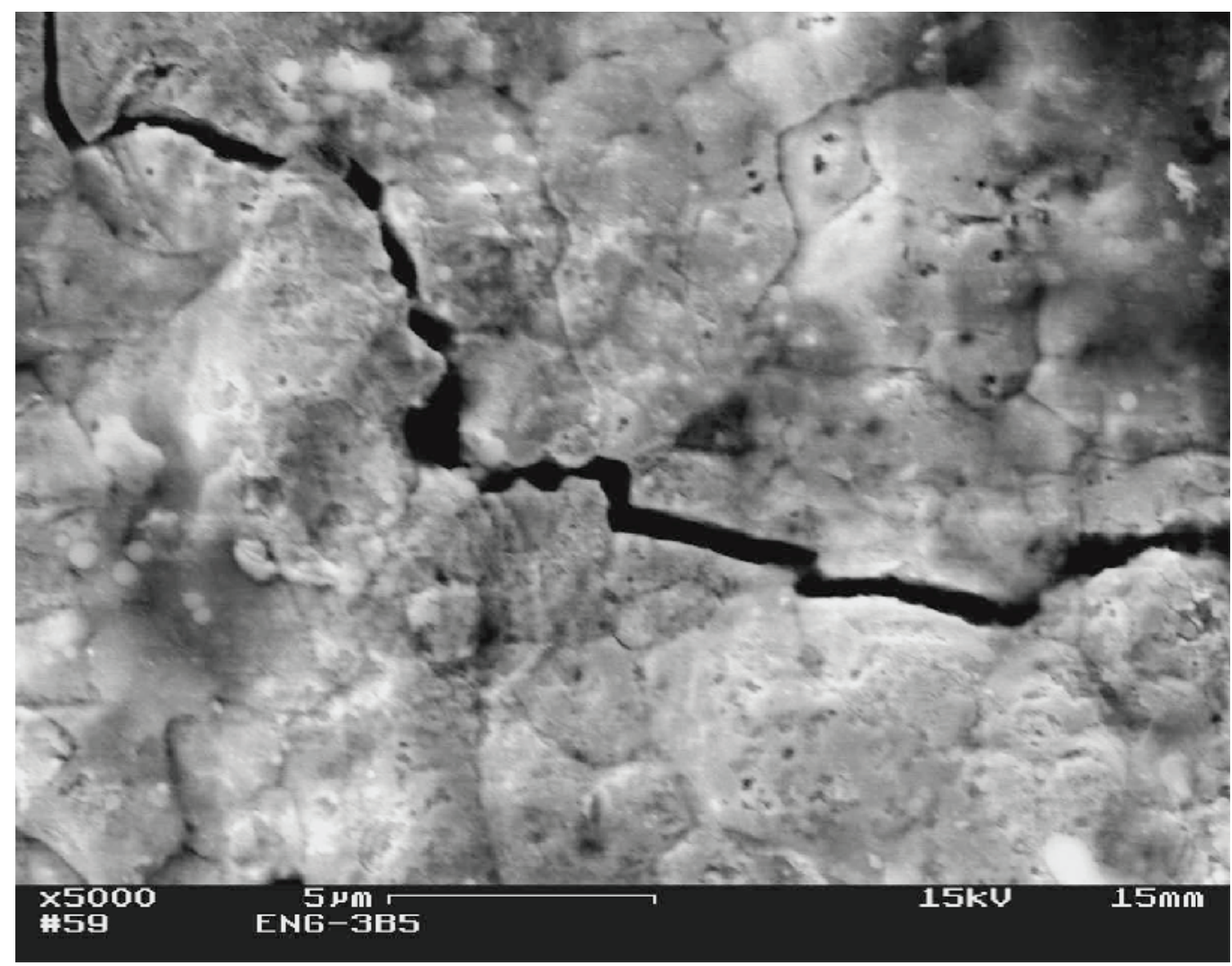

Figure D14. Grain of amalgam showing fracture (sample 3B5). 


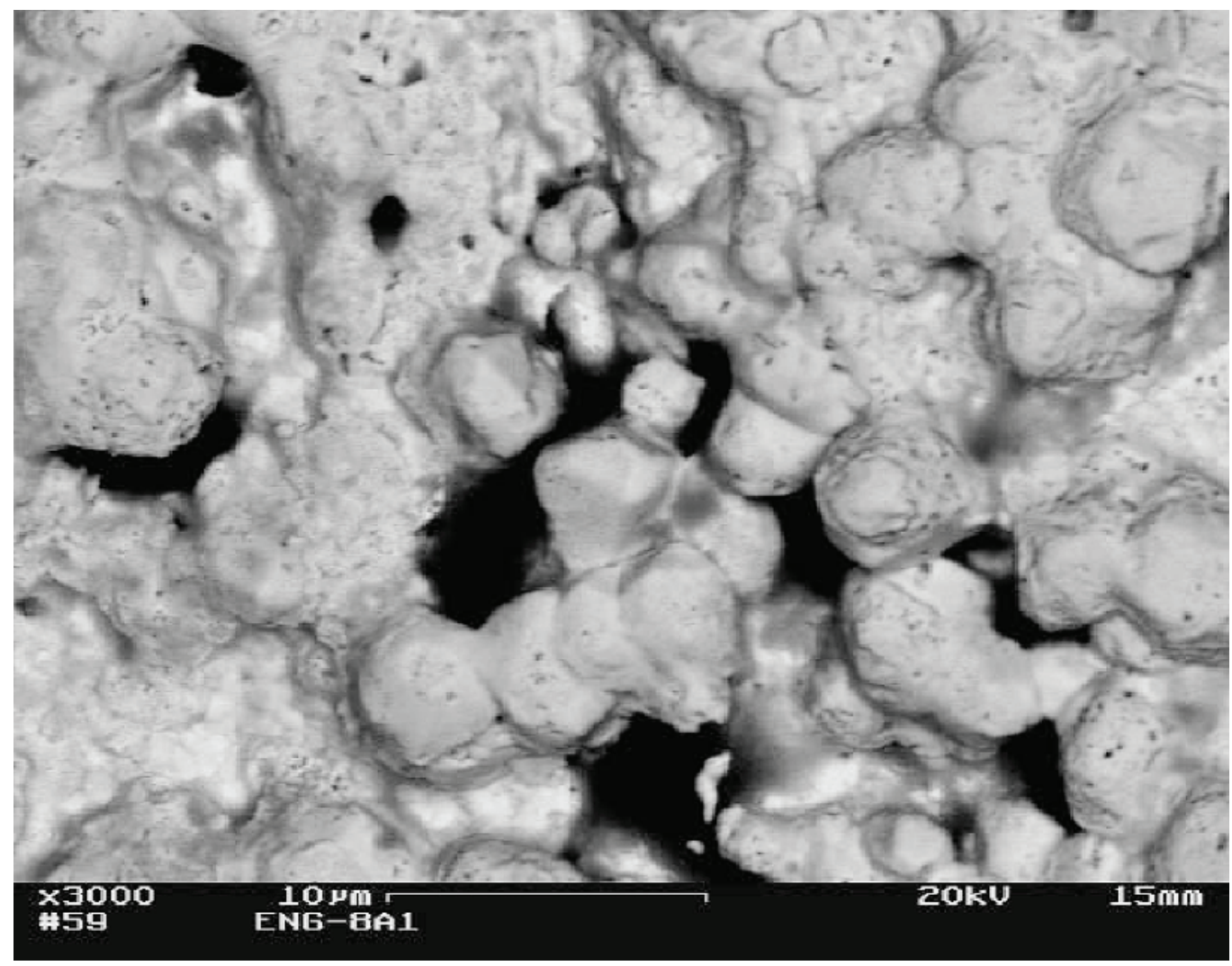

Figure D15. Octahedral crystal forms of gold in vug of nugget (sample 8A1).

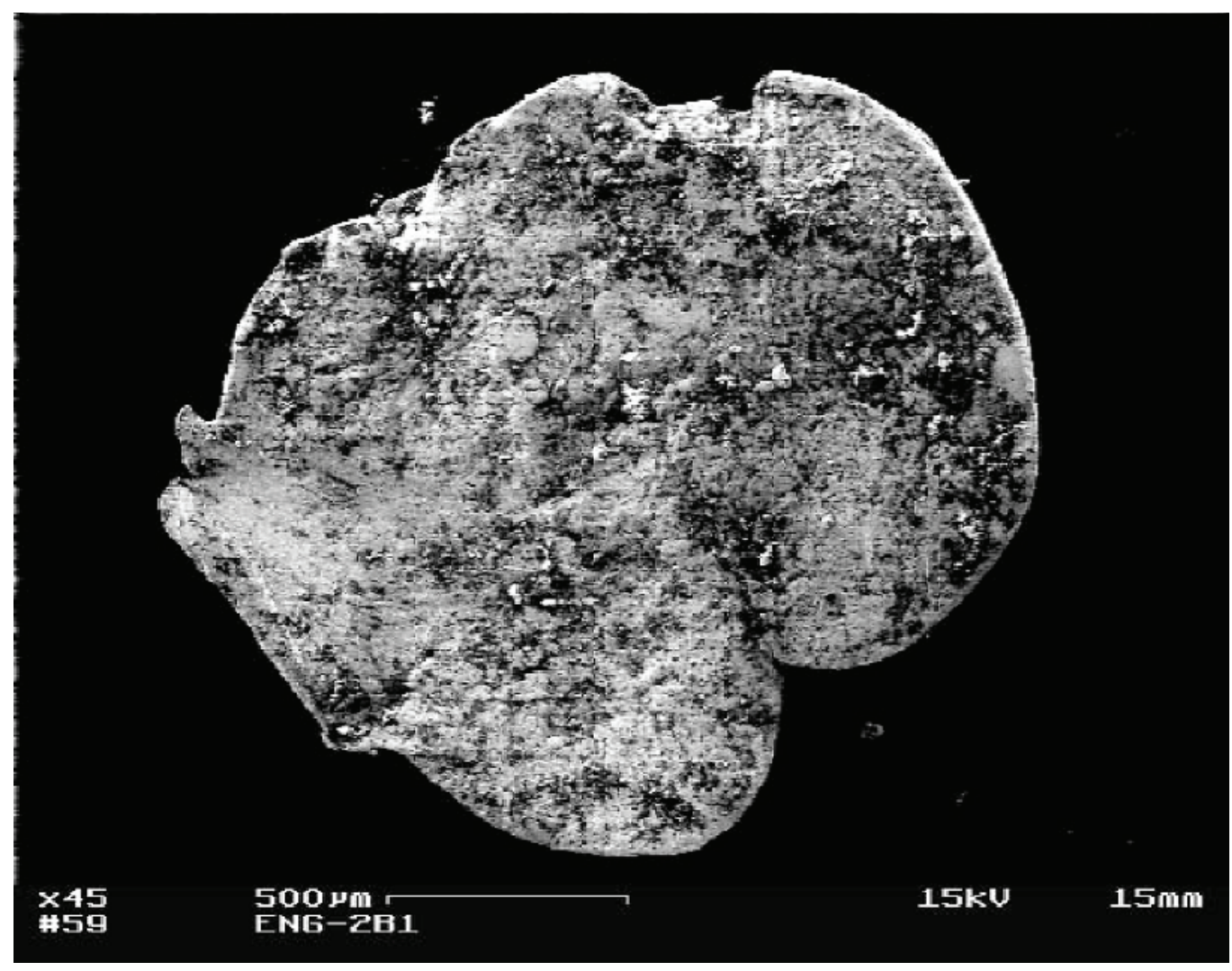

Figure D16. Iron-stained gold nugget with no trace of mercury (sample 2B1). 
